\title{
NITRIFICATION BY IMMOBILIZED CELLS
}

$20 \mathrm{bmpn}$

René H. Wijffels 
Promotor: dr. ir. J. Tramper

hoogleraar in de bioprocestechnologie 


\section{5: 1800}

\section{René H. Wijffels}

\section{NITRIFICATION BY IMMOBILIZED CELLS}

\section{Proefschrift}

ter verkrijging van de graad van doctor

in de landbouw- en milieuwetenschappen, op gezag van de rector magnificus, dr. C.M. Karssen, in het openbaar te verdedigen op maandag 20 juni 1994 des namiddags te vier uur in de aula van de Landbouwuniversiteit Wageningen 


\section{BIBLIUIHEEN ANDBOUWUNIVERSED \\ DAGENINGEN}

\section{Cover:}

Micro-colonies of Nitrosomonas europaea.

Nitrifying bacteria convert ammonia into nitrate. In this study bacteria were immobilized 'artificially' in a hydrophylic gel.

Growth and substrate consumption by these bacteria was studied. Growth appeared by expansion of micro-colonies. Colonies near the surface of the gel bead were larger as a consequence of diffusion limitation over the gel.

Ontwerp kaft:

met dank aan Hans Wijfels, Boudewijn van Veen en lda Akkerman 


\section{NNJOS701,1800}

\section{STELLINGEN}

1. Indien de door Keen en Prosser gevonden kinetische parameters voor Nitrobacter juist zijn, zou dit organisme niet bestaan.

Keen G.A., Prosser J.I. (1987) Steady state and transient growth of autotrophic nitrifying bacteria. Arch Microbiol 147: 73-79

2. Bij vergelijking van geïmmobiliseerde cellen met gesuspendeerde cellen wordt ten onrechte diffusielimitatie als nadeel van immobilisatie genoemd.

Dit proefschritt

3. Bacteriën groeien tegen de verdrukking in.

Stewart P.S., Robertson C.R. (1989) Microbial growth in a fixed volume: studies with entrapped Escherichia coli. Appl Microb Biotechnol 30: 34-40

4. Polyvinylalcohol zal voor de meeste micro-organismen niet geschikt zijn als dragermateriaal indien het met de boorzuurmethode geproduceerd wordt.

Hashimoto S., Furukawa K. (1987) Immobilization of activated sludge by PVA-boric acid method. Biotechnol Bioeng 30: 52-59

5. Het door Kokufuta beschreven gecoïmmobitiseerde systeem van nitrificerende en denitrificerende bacteriën, waarbij beide soorten over de gehele drager verdeeld zijn werkt alleen in kortdurende experimenten.

Kokufuta E., Shimohashi M., Nakamura I. (1988) Simultaneously occurring nitrification and denitrification under oxygen gradient by polyelectrolyte complex-coimmobilized Nitrosomonas europaea and Paracoccus denitrificans cells. Biotechnol Bioeng 31: 382-384

6. Onderzoeksscholen zijn in het leven geroepen om minder geld op een andere manier te verdelen. 
7. Het aantal terreinauto's neemt evenredig toe met het geasfalteerde oppervlak.

8. Het jarenlange overleg omtrent verandering van de openingstijden van winkels, resulterend in een verlengde openingstijd van een half uur, kan worden bestempeld als zonde van de tijd.

9. Als ook in restaurants de klant koning is, dan is veel van het bedienend personeel republikeins.

10. Het toelaten dat mestquota omzeild worden door struisvogelfarms op te zetten is een vorm van struisvogelpolitiek.

11. Uit het feit dat een puddingbroodje gezonder is dan een broodje 'gezond', omdat het minder vet bevat, kan de conclusie getrokken worden dat het gezonder is helemaal geen broodje te eten.

Stellingen behorende bij het proefschrift 'Nitrification by Immobilized Cells'.

\section{R.H. Wijfels}

Wageningen, 20 juni 1994. 
aan mijn ouders

voor Ida 


\section{VOORWOORD}

In dit proefschrift worden fundamentele aspecten van geïmmobiliseerde cellen voor toepassing binnen de milieubiotechnologie behandeld. Meermalen is dit toepassingsaspect aan de orde geweest en ik ben de hele periode achtervolgd geweest met de vraag: "Denk je nou echt dat die bolletjes in afvalwater toegepast kunnen worden?" Nee, dat denk ik niet. Dit is een fundamentele studie geweest die het inzicht heeft vergroot en die duidelijk de mogelijkheden van geïmmobiliseerde cellen binnen de milieubiotechnologie en andere gebieden heeft laten zien. Het laat zien dat het de moeite waard is naar stabiele dragermaterialen te zoeken om dergelijke processen ook werkelijk toe te passen. Wij hebben bewust niet gekozen eerst een systeem toe te passen en vervolgens te begrijpen. Wij zijn andersom te werk gegaan.

Bij deze benadering heb ik veel steun gekregen van Hans Tramper, mijn promotor. Ik heb een grote vrijheid gekregen, en er was altijd ruimte voor overleg. Discussies waren altijd zeer verhelderend voor mij.

Kees de Gooijer is nauw betrokken geweest bij de ontwikkeling van de in dit onderzoek gebruikte modellen. Die modelontwikkeling heeft het tot dan toe soms erg kwalitatieve onderzoek met geïmmobiliseerde cellen op een hoger niveau gebracht naar mijn idee.

Experimenten werden uitgevoerd in air-lift loop reactoren. Samen met Ido Wolters en Rens Vreeburg zijn vele ontwerpen gemaakt voordat ze aan alle eisen voldeden.

Bij Proceskunde is een groepje ontstaan waarin gewerkt wordt aan nitrificatie en denitrificatie met geïmmobiliseerde cellen. Binnen dit groepje wordt goed samengewerkt en ik wil daarvoor de mensen die hier van deel uitmaken of maakten bedanken: Jan Hunik (de prettige treinreis naar Budapest zal ik niet snel vergeten), Vítor Santos, Imke Leenen, Ida Günther en José Obón. Ook mijn andere collega's wil ik graag bedanken voor de prettige werksfeer en alle activiteiten naast het werk.

Aan dit onderzoek hebben veel studenten meegewerkt, zonder wie dit nooit tot stand zou zijn gekomen. Zij hebben een essentiële bijdrage aan dit werk geleverd: Ingrid Gaemers, Gertjan Smolders, Sjon Kortekaas, Carlos Vilchez, Wim Dodde, Leonard Mallée, Meinard Eøkhof, Marleen Verheul, Evelien Beuling, Serge Lochtmans, Ana Becerril Rojas, Hans van 't Noordende en Aldo Schepers.

Professor Willemse van de vakgroep Plantencytologie en -morfologie wil ik bedanken voor het beschikbaar stellen van de apparatuur om dunne coupes van 
bolletjes te kunnen maken. We werden hierbij begeleid door Marieke Smit.

Metingen met micro-electrodes werden uitgevoerd aan de Universiteit van Amsterdam. Ik heb op prettige wijze samengewerkt met Dirk de Beer en Han van den Heuvel.

De medewerkers van de werkplaats, fotolocatie, tekenkamer, afdeling automsatisering, bibliotheek en magazijnen van de Centrale Dienst Biotechnion wil ik bedanken voor hun verrichtte diensten.

Bij Proceskunde ben ik veel sportiever geworden. Marcel Zwietering liet me lopen en naar de kroeg gaan als voorbereiding op de Veluweloop, Anja Janssen zorgde er altijd voor dat ik geen nee kon zeggen tegen het zwemkilometertje van tussen de middag, Rhea Rekker leerde me fierljeppen, Gerrit Heida liet een nieuwjaarsreceptie vitlopen in een schaatstochtje, Henk van Sonsbeek liet met $112.5 \mathrm{~km}$ in de Ardennen fietsen en Jan Hunik gaf me mijn eerste skiles door aan te wijzen dat ik naar beneden moest gaan (ik lig er soms nog wakker van).

Het woon-werk verkeer werd veraangenaamd door mijn medecarpoolers: Eveline Vaane, Gab van Winkel, Charles Crombach en Jos Frijns. Alle roddels aan de LU werden tijdens die ritjes behandeld. 


\section{CONTENTS}

1. Nitrification by immobilized cells

2. Performance of growing Nitrosomonas europaea cells immobilized in carrageenan

3. Growth and substrate consumption of Nitrobacter agilis cells immobilized in carrageenan: part 1. dynamic modelling

4. Growth and substrate consumption of Nitrobacter agilis cells immobilized in carrageenan: part 2. model evaluation

5. Pseudo-steady-state oxygen-concentration profiles in an agar slab containing growing Nitrobacter agilis

6. Dynamic modelling of immobilized Nitrosomonas europaea: implementation of diffusion limitation over expanding micro-colonies

7. Effect of initial biomass concentration on the growth of immobilized Nitrosomonas europaea

8. Immobilized cells: model or practical system?

Summary

Samenvatting 181

Bibliography 185

Curriculum vitae 188 


\section{CHAPTER 1}

\section{NITRIFICATION BY IMMOBILIZED CELLS}

\section{ABSTRACT}

The capacity of reactors in which nitrification takes place can be improved by increasing the biomass-retention time independent from the liquid-retention time. This is done by immobilization of the bacterial cells. Natural immobilization of bacteria by spontaneous attachment to inert support materials is widely used in wastewatertreatment systems, in so-called biofilm processes. An alternative technique is artificial immobilization by entrapment in gel materials.

Immobilized-cell processes are complex because of the interaction of many factors. Understanding of the process can be improved by basic knowledge of the important factors involved, and by modelling the interactions of these factors. Biofilm models that have been developed can be divided in steady-state and dynamic models. A factor that limits further understanding of the process is uncontrolled biofilm loss because of, for instance, shear. This factor determines the thickness of the biofilm and as a result the capacity of the film. Dynamic models for artificially entrapped cells have been developed as well. 
Techniques have been developed with which components inside biofilms can be analyzed. With micro-electrodes profiles of substrates and/or products over the support can be measured, and by slicing the support in combination with staining techniques, specific biomass profiles can be determined. These techniques are important tools for evaluation of models that describe growth and substrate consumption of immobilized cells.

The various aspects mentioned above are reviewed in this paper.

\section{INTRODUCTION}

Industrial and agricultural developments lead to an increased prosperity in Europe after the Second World War. In the Netherlands this development was accompanied by an exponential growth of the human population. This period of prosperity and growth also showed its negative side-effects. It became clear that economic growth should be more controlled and that negative environmental effects had to be reduced strongly. This resulted in laws to regulate discharge of wastewater. Intensive treatment of wastewater started more than 30 years ago now. Initially it was focused on the removal of organic components that cause an increased oxygen demand in the receiving surface waters.

Although much progress has been made, many pollutants still cause problems. To these pollutants belong the eutrophication-causing nitrogen compounds. Traditional wastewater-treatment systems often do not offer effective solutions for nitrogen removal. Atthough it is possible to accomplish nitrification in the more conventional systems like activated-sludge plants and trickling filters, the nitrification capacities of these systems are poor.

The process of nitrification is known for a long time. Especially the fact that the produced nitrate was a source for gunpowder made the process economically attractive already in the 13th century. One of the methods to produce nitrate was by means of dung hills over which urine and water were percolated. This system can be considered as a precursor of the modern manure-treatment factories, which are currently in development in the Netherlands. In that time producers were not aware of the biological fundament of this process. At the end of the 19th century it became clear that the basis of nitrification was biological; nitrification was a two-step oxidation 
of ammonia via nitrite to nitrate, catalysed by autotrophic bacteria. ${ }^{61}$

Since then nitrification has been studied extensively; thousands of papers have been published about isolation, biochemistry, kinetics, inhibition, applications and ecological significance. Extensive reviews are the papers of Sharma and Ahlert, ${ }^{93} \mathrm{Focht}$ and Verstraete, ${ }^{29}$ Painter, ${ }^{74,75}$ Schmidt, ${ }^{91}$ Barnes and Bliss ${ }^{4}$, Belser ${ }^{6}$, Kuenen and Robertson ${ }^{50}$ and Prosser. ${ }^{79}$

In recent years nitrification received much attention because of its environmental significance in the nitrogen cycle, in the greenhouse effect, in acid rain and in eutrophication. ${ }^{6.29,50.79}$ It is shown for example that not only autotrophic nitrifying bacteria play an important role but that in many cases heterotrophic species are important as well, although their nitrifying activities are significantly lower than those of autotrophic nitrifying bacteria. Under some conditions, like in acid soils, heterotrophic nitrification is the dominant process. ${ }^{20,50}$ For the treatment of wastewater nitrification with autotrophic bacteria received most attention. It has been shown that under these conditions autotrophic nitrification is favourable and rates are orders of magnitude higher than those of heterotrophic bacteria., ${ }^{4,200}$

The growth rate of autotrophic nitrifying bacteria is low compared to heterotrophic bacteria, with which they have to compete for oxygen. In activated-sludge plants, both availability of oxygen and the slow growth rate are reasons that nitrification often does not occur. A favourable condition for nitrification is an increased sludge age (4 days or more). This depends on the applied dilution rate and the biomass concentration that can be reached in the reactor. The biomass concentration is increased by recirculation of the sludge after sedimentation, but will be limited by the efficiency of the sedimentation vessel. In practice this means that the dilution rate in activated sludge plants with nitrification is limited to 0.2 hours $^{-1}$. 430,77,83 $^{-3}$

Immobilization is an efficient method to retain slow-growing organisms in continuous-flow reactors. Immobilized cells can be divided in 'naturally' attached cells (biofilms) $^{26,32,33.52}$ and 'artificially' immobilized cells. ${ }^{20}$ The residence time of the liquid phase in these systems may be chosen independently of the specific growth rate and as a result immobilized-cell reactors can be compact in comparison to activated-sludge plants. ${ }^{20,28}$ The conversion rate in such high-rate reactors is limited by diffusion of substrates. This has been demonstrated several times by the fact that cells grow preferentially as a film just underneath the surface of the beads in case cells have been artificially immobilized by entrapment in a gel..$^{20,120}$ For this reason substrate 
conversion rates tend to be proportional to the surface area and not to the total mass of the organisms. ${ }^{20,26,32,33,52,121}$

\section{IMMOBILIZED CELLS}

\section{Naturally attached cells (biofilms)}

The trickling filter is the most widely applied immobilized-cell system. A trickling filter is a percolating filter consisting of a bed of a porous support on which a biofilm develops. In first instance the support materials used were lava and stone which have relatively limited external specific surface areas $\left(100 \mathrm{~m}^{2} . \mathrm{m}^{-3}\right)$. In the second generation of trickling filters plastic media were used with a specific surface area of $100-300 \mathrm{~m}^{2}$. $\mathrm{m}^{-3}$. Although the specific surface area of trickling filters is still small, the system is widely used because there is much practical experience with them. Knowledge of the process in wastewater treatment, however, is mainly empirical.

A system with a comparable specific surface area is the rotating biological contactor. In a rotating biological contactor the biofilm is attached to discs. A large number of these discs are closely arranged and mounted on a shaft which rotates in the reactor. The discs are partly submerged in the sewage. As the shaft rotates slowly, attached biomass is alternately exposed to air and sewage.

Both trickling filters and rotating biological contactors have a limited capacity because of the relatively low specific surface area of the support. High-rate biofilm reactors have a much higher specific surface area, usually accomplished by using small particles (e.g. sand). Examples of compact systems are the packed-bed and fluidized-bed reactors. The reactors contain small solid particles with an attached biofilm. The specific surface area is about $3000 \mathrm{~m}^{2} . \mathrm{m}^{-3}$. Aerated wastewater moves through the bed. The limitation of these systems is, that the transfer of oxygen from the gas phase to the liquid phase is low and therefore often oxygen depletion along the length of the reactor occurs. The capacity of these reactors is thus limited by oxygen supply. In case of fluidized-bed reactors increased oxygen transfer rates can be reached by sparging air in the column, creating a three-phase reactor. ${ }^{0,26,84,101,113}$ Similar capacities can be reached in fluidized-bed systems with a draft tube, air-lift loop reactors, which have a more defined liquid flow. ${ }^{34}$ 


\section{Artificial immobilized cells}

Immobilized-cell reactors with naturally attached biomass are controllable to a limited extent and underlying mechanisms are not very well understood. A better defined and more controllable system is obtained by 'artificial' immobilization of pure strains of bacteria (text box). In order to understand more about the mechanisms pure cultures with known kinetics and gel beads with known diffusion coefficients and geometry can be used.

\section{Immobilization technique}

One of the most common techniques for 'artificial' immobilization is gel entrapment. Materials that are widely applied for entrapment are alginate and carrageenan. For this, solutions of polymers containing suspended cells are extruded drop wise into a solution where gelation of drops into solid spheres is initiated (Fig. 1). In case of alginate and carrageenan gelation is initiated by $\mathrm{Ca}^{2+}$ and $\mathrm{K}^{+}$, respectively. ${ }^{122}$ It is possible to scale up the extrusion technique by using a resonance nozzle. In that case a vibration is exerted on the suspension which causes break-up of the jet into drops with a frequency of $200-700 \mathrm{~Hz} .{ }^{37}$ Recently this resonance nozzle technique has been further scaled up by applying the vibration on 6 jets (Fig. 2). ${ }^{38}$

The use of artificially immobilized cells is an alternative for biofilm systems and was introduced for denitrification by Mattiasson et al., ${ }^{54}$ Nilsson and Ohlson ${ }^{70,71}$ and Nilsson et al ${ }^{72}$ Subsequently, artificially immobilized cells were used for nitrification in laboratory studies by Kokufuta et al., ${ }^{47}$ Van Ginkel et al. ${ }^{111}$, Tramper and De Man, ${ }^{106}$ Tramper and Grootjen, ${ }^{107}$ Lewandowski et al. ${ }^{56}$ Ariga et al. ${ }^{3}$, Myoga et al. ${ }^{68}$ Tada et al. ${ }^{100}$ and Tanaka et al. ${ }^{102}$ Recently the first technical process with artificially immobilized nitrifying cells at a scale of $750 \mathrm{~m}^{3}$ has been constructed. In this process polyethylene glycol pellets containing nitrifying activated sludge are used for nitrification of domestic wastewater. The system has been operational stable for a period of 3 years now.

In principle, artificial immobilized cells can be used to integrate nitrification and denitrification within a single biocatalyst particle. ${ }^{48,49,56,89,90,108}$ Due to diffusion limitation of oxygen the nitrifying organisms will concentrate in a biofilm just under the surface of a gel particle, leaving the anoxic central part completely unused. Denitrification may occur in the bead core if suitable denitrifying bacteria are present and if organic substrate is available. 
Chapter 1

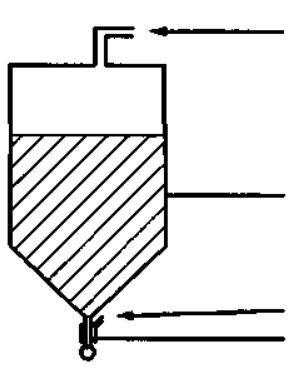

air pressure

gel-biocatalyst

suspension

airflow

needle

○

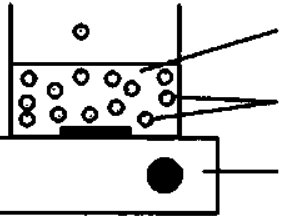

$\mathrm{CaCl}_{2}$ or $\mathrm{KCl}$

solution

immobilized

biocatalysts

magnetic stirrer

Fig. 1: Schematic representation of drop wise extrusion of alginate or carrageenan in a $\mathrm{CaCl}_{2}$ or $\mathrm{KCl}$ solution where gelation is initiated. ${ }^{37}$

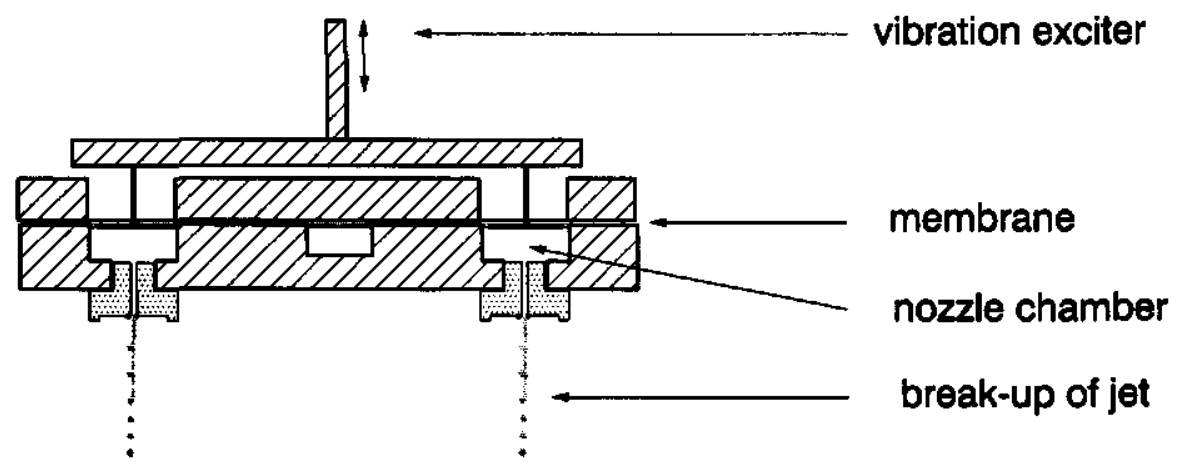

Fig. 2: Schematic representation of the resonance-nozzle technique. ${ }^{30}$ 


\section{BASICS OF IMMOBILIZED-CELL PROCESSES}

\section{Naturally attached cells (biofilms)}

Biofilm systems are complex (Fig. 3) due to a combination of factors like bacterial growth, substrate consumption, attachment, external/internal mass transfer of substrate and products, cell death, shear loss (biofilm loss because of erosion), sloughing (fragments disrupt from the film), structure of the support material, competition between bacterial species, effects of predators. All these factors play a significant role in the overall capacity of the biofilm process. Process conditions like the concentration of substrate, temperature, $\mathrm{pH}$, turbulence, dilution rate will all influence these factors differently (Table 1). For example, increasing the turbulence influences most factors mentioned:

i) The stagnant-liquid layer at the film interface will be thinner and as a result of that the external mass-transfer resistance will be lower.

ii) Lower external mass-transfer resistance results in an increased penetration depth in the biofilm and therefore both substrate consumption rate and growth rate will increase.

iii) Shear rates will increase.

iv) Consequently, the rate of attachment of cells and the type of cells that attach will be influenced (biofilms grown at higher shear stresses are dense and less sensitive to high shear stress)..$^{11,83}$

v) In dense biofilms, diffusion coefficients and biomass concentration will be different than in less dense biofilms.

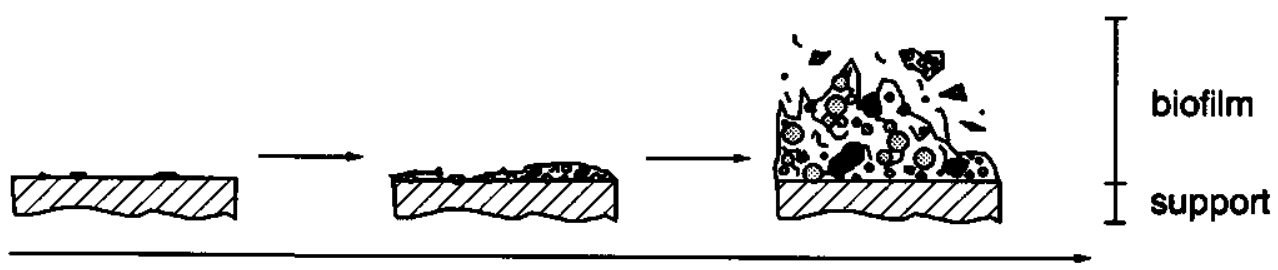

time

Fig. 3: Schematic representation of the formation of a biofilm. 
Table I: Process conditions (temperature, turbulence and dilution rate) that effect biofilm kinetics

\begin{tabular}{llll}
\hline & temperature & turbulence & dilution rate \\
external mass transfer & + & & 0 \\
attachment & $?$ & + & + \\
shear loss & + & + & + \\
sloughing & + & + & + \\
substrate consumption & + & + & 0 \\
biofilm density & $?$ & + & + \\
diffusion & + & 0 & 0 \\
$+=$ increase; $-=$ decrease; $0=$ no effect; ? = not predictable
\end{tabular}

In order to have insight in the interactions of these factors it is essential to obtain basic information about these factors. Subsequently insight in the complex relationships between the different factors can be gained in model studies. It may be clear that it is difficult to study these factors independently in situ as they are all related.

Several biofilm models have been developed, in which substrate transport to, and consumption by the immobilized cells is described. In the majority of those models, however, lack of basic knowledge in the relevant factors and simplifications restrict the insight. Generally the developed models can be divided in steady-state models without growth and dynamic models with growth.

\section{Steady-state models without growth}

Many steady-state models describing substrate concentration profiles over biofilms have been developed. In many of the models zero or first-order kinetics were assumed so that analytical solutions were available, ${ }^{26,31,32,33,52,82,126,127}$ but also numerical solutions were used. ${ }^{118}$ In the steady-state models the biomass distribution over the entire film is assumed homogeneous. In reality the biofilm density is not constant over the entire film. ${ }^{17,60}$ Gradients develop because the growth rate is dependent on the local substrate concentrations and in the deeper layers decay of cells occurs. For this reason the assumption of a homogeneous biofilm composition is doubtful.

The major limitations of the steady-state biofilm models are i) that the thickness of 
the steady-state biofilm must be known and that ii) obviously only the steady state is described which means that it does not give insight in the response of the process to changes.

Steady-state biofilm models increase insight in biofilm processes in the case of thick films, in which the penetration depth of substrate is smaller than the film thickness. In that case, accurate information about the total thickness of the film for determination of the capacity is not so important. In the case of thinner films, however, the thickness is a key parameter.

\section{Dynamic models with growth}

In dynamic biofilm models bacterial growth is taken into consideration. Substrate consumption and growth are treated separately. This is a valid approach as long as the time scale for growth is much larger than the time scale for substrate consumption. Substrate concentration profiles over biofilms are calculated by numerical solutions as a function of time..$^{2.5,13,44,105,117}$ in case of growing biofilms this will result in steeper profiles later in time.

In dynamic biofilm models, the thickness or the density of the biofilm will increase or decrease as a function of time. Consideration of the varying amount of biomass in the film is essential to study the dynamics of the system. To illustrate this, two examples will be given: i) the effect of changing temperatures and ii) competition between different species of organisms.

i) The substrate-consumption rate is a function of temperature. At temperatures below the optimum, the consumption rate will be lower. In the case of immobilized cells this results in a larger substrate-penetration depth. If viable biomass is present in the deeper layers of the biofilm, the substrate will be consumed in the deeper layers and the decreased capacity of the biofilm will partly be counterbalanced. In case, however, cells in deeper shells are not viable, the capacity of immobilized cells is more sensitive to temperature changes than in deep biofilms. ${ }^{123}$

ii) Competition between different species in a biofilm will result in a heterogeneous distribution. Wanner and Gujer ${ }^{116,117}$ showed that such a biofilm is built up of layers with different types of micro-organisms. In case for example both nitrifying and denitrifying cells are present, the organisms will compete for oxygen. As a result, nitrifying cells will to some extent be overgrown by denitrifying cells which will have an effect on the 
performance of the system.

In dynamic biofilm models, the biofilm thickness and/or the maximum cell density need to be restricted to a maximum. Basically, a biofilm will expand in depth as long as the growth rate is higher than the rate of decay or the rate of attrition. Usually sloughing, shear loss or some limitation in growth rate will restrict the thickness of the film. If the growth is not restricted in some way or if no biofilm is removed in one way or another, the film would become infinitely thick. ${ }^{15}$ Possibilities to restrict the thickness of the biofilm to a maximum are introduction of i) logistic growth ${ }^{13,44,105}$ or ii) assumption of biofilm loss at the maximum thickness. ${ }^{2,5,117}$

i) In the logistic growth models it is assumed that growth is proportional to the available space. The growth rate decreases as a function of biomass concentration. Logistic growth models have been used for anchorage-dependent animal cells ${ }^{59}$ and for growth of nitrifying cells in soil. ${ }^{65,78}$ For bacterial cells, however, logistic growth is not very likely. Stewart and Robertson ${ }^{98}$ showed that growth rate is not a function of available space, by growing $E$. coli in a fixed volume while substrate was available in excess. In their reactor pressure increased to 6 bar as the result of growth. The final concentration of cells reached in the fixed volume approached the cellular dry weight content. Also for immobilized cells it has been shown that growth continues even if space is limited. Cells are packed so densely in the micro-colonies formed, that no space between cells can be observed with electron microscopy. ${ }^{27,62,73,103,104}$ In the case that cells were immobilized in hollow-fibre reactors, membrane disruption due to pressure build-up inside colonies was observed resulting in cell excretion. ${ }^{42,43}$

ii) Excessive expansion of the film can be restricted by implementation of biofilm attrition. ${ }^{25.117}$ The most simple way to do this is by cutting of the film expansion at a defined maximum biofilm thickness. The maximum thickness can assumed to be obtained as soon as the calculated maximum penetration depth of the limiting substrate in the film is reached. This is the depth at which the substrate concentration is zero. ${ }^{2,5}$ Further increase leads to attrition due to sloughing or shear loss. In practice, attrition does not necessarily occur at the maximum penetration depth of the limiting substrate but can occur sooner (in thin biofilms) or later (in thick biofilms). Biofilm loss is not only a function of the combined processes of substrate diffusion and consumption but also the result of turbulence on the biofilm surface. Several studies have been done on shear loss ${ }^{11,14,83,109}$ but further investigation is essential for understanding biofilm processes. 
A different approach for studying dynamics of biofilm processes is formed by using more simplified systems in which less factors play a role and where basic knowledge of the important factors is available. In this respect immobilized-cell systems with entrapped cells form a much better defined and therefore a more adequate system for model evaluation.

\section{Artificially immoblized cells}

In order to understand the interactions of mass transfer in films and the kinetics of immobilized cells, artificially immobilized cells form an excellent model system. In Fig. 4 the immobilized-cell process is schematically shown for an aerobic conversion with oxygen as the limiting substrate. Oxygen is supplied to the reactor system by means of air bubbles. The oxygen will be transferred from the gas phase to the liquid phase across a stagnant liquid layer surrounding the gas bubble. The liquid phase is assumed to be perfectly mixed. From there the oxygen will be transported through a stagnant layer surrounding the gel bead to the gel surface, through the gel bead, into

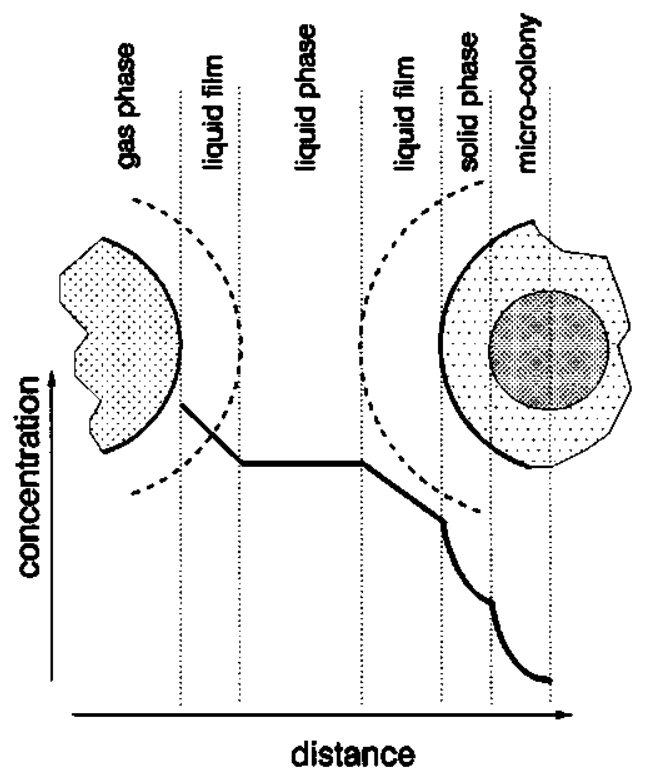

Fig. 4: Transport of oxygen from the gas phase to immobilized cells where conversion occurs. 


\section{Micro-colonies}

Growth of immobilized cells appears as expanding micro-colonies. Colonies near the surface of the gel beads will be larger than the colonies in the centre as the result of diffusion limitation (Fig. 5). The colonies provide their own space in the gel. ${ }^{54}$ Due to expansion of the colonies, the cells will eventually reach the surface of the gel bead, the colony surface will confluence with the gel surface and cells are released into suspension. ${ }^{122}$ The process of cell release is schematically shown in Fig. 6. In steady state the cell-leakage rate will be equal to the net biomass production rate. Release of cells was confirmed in the experiments of Inloes et al ${ }^{42,43}$ and Wijffels et al. ${ }^{123}$ Inloes et al. found membrane disruptions in hollow-fibre reactors containing growing cells.

micro-colonies (text box) and finally reaches the microorganisms where consumption will occur. As cells grow in micro-colonies, transport of substrate in these colonies is also taking place.

Similar to models for attached biofilms, growth needs to be restricted to a maximum in dynamic models of entrapped cells. If the biomass concentration is not restricted, an infinitely thin film of biomass with an infinitely high concentration would ultimately be obtained.

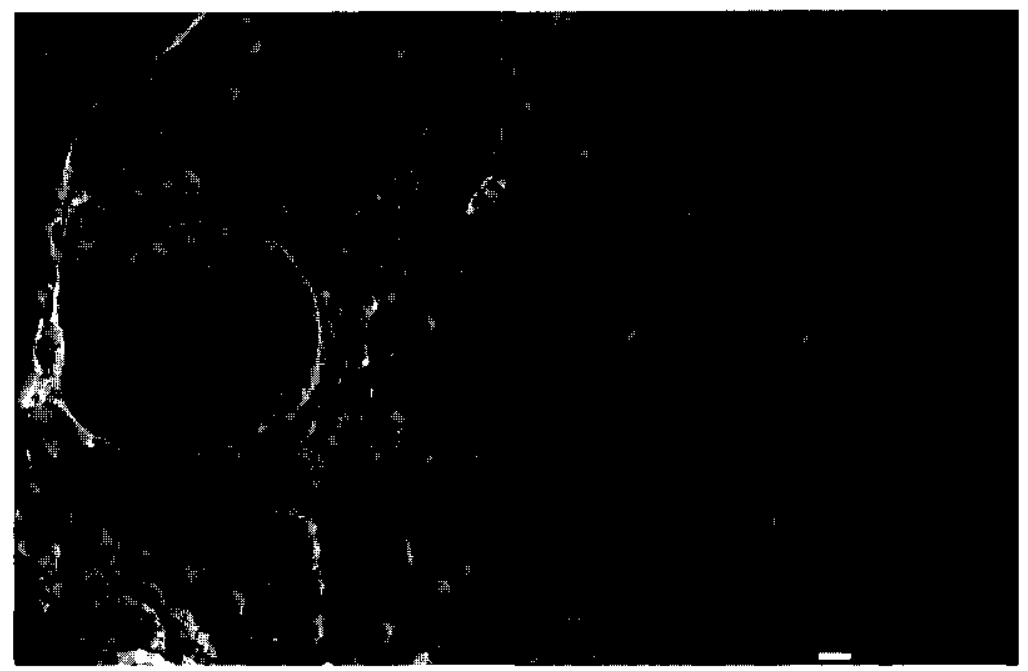

Fig. 5: Inner peripheral surface of a carrageenan bead showing various-size micro-colonies of Nitrosomones europeea, bar length $10 \mu \mathrm{m} .^{112}$ 
Several dynamic models have been developed in which maximum biomass concentrations are defined. ${ }^{24,40,66,69}$ Values for maximum biomass concentrations were obtained experimentally by determination of the volumetric fraction of biomass near the surface of the beads by image analysis. ${ }^{40,66,122}$ There was, however, not a physical reason for limiting the concentration to this maximum as in none of the cases described the subsurface region was fully occupied by micro-colonies. In reality the biomass concentration in the subsurface region will be limited because colonies erupt from the gel bead and/or colonies become so large that the growth rate is limited by diffusion limitation over the colonies. Diffusion limitation over micro-colonies and cell eruption can be implemented in the models by considering growth as expansion of micro-colonies..$^{25.86,122}$ Micro-colonies near the surface of the bead grow faster and as a result are larger than the colonies in deeper layers. Colony expansion near the surface may result in fusion of different colonies if they approach each other, ${ }^{86} \mathrm{grow}$ out of the beads by an eruption like process, ${ }^{121}$ or are further limited in their growth by diffusional restrictions over the micro-colonies. ${ }^{122}$ By implementation of diffusion limitation over the colonies and by biomass release due to colony eruption as soon as colonies touch the gel surface, it was found there was no need to implement a maximum biomass concentration. ${ }^{122}$

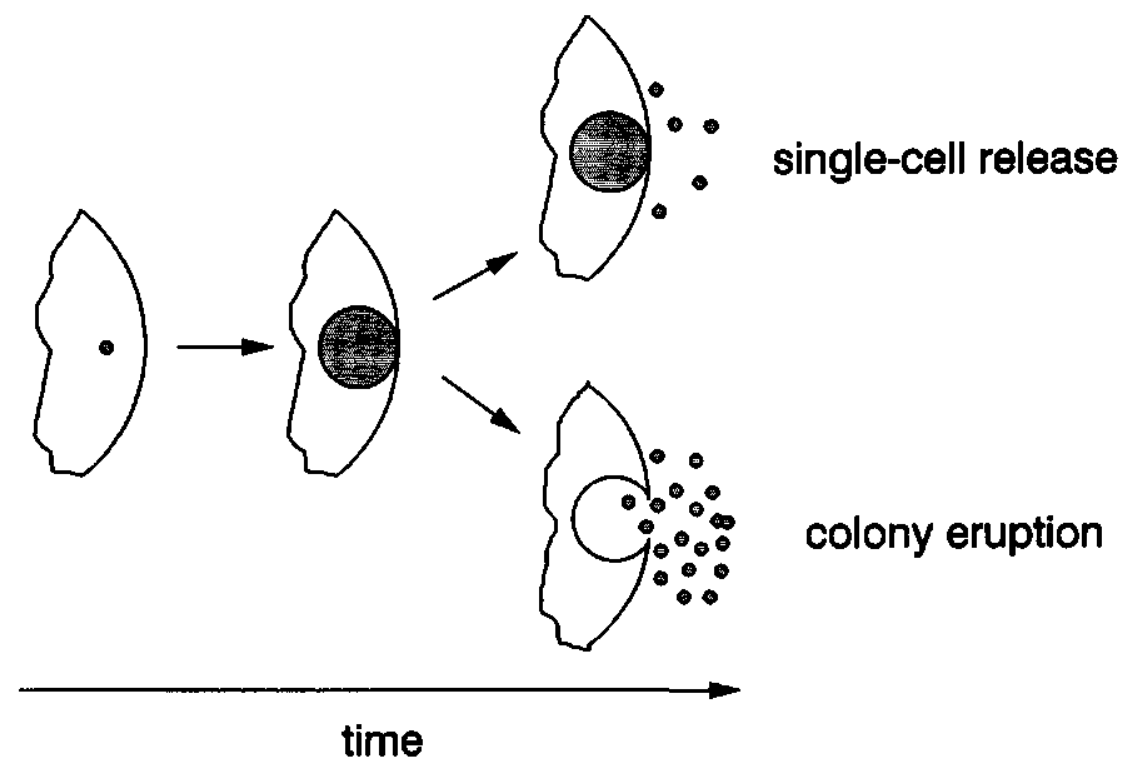

Fig. 6: Schematic representation of growth of artificially immobilized cells by colony expansion. 


\section{PARAMETER ESTIMATIONS}

The quality of model results is to a great extent dependent on the quality of the parameter estimation. Significant insight in the process can be obtained if parameters are obtained in independent experiments. Fitting of parameter values should therefore be avoided. For immobilized cells three types of parameters have to be considered, i.e., intrinsic kinetic parameters, physical parameters of the support containing the biomass and hydrodynamics-dependent physical parameters.

\section{Intrinsic kinetic parameters}

Intrinsic kinetic parameters that are important for growth of immobilized cells are the maximum specific growth rate, substrate affinity constants, biomass-yield coefficients and parameters that are related to maintenance and decay.

In literature the kinetics of nitrification have been described extensively. The reliability of the reported values of kinetic parameters is, however, often limited because experimental procedures showed serious deficiencies. ${ }^{53,90,97}$ Observed differences between intrinsic values and the values measured in bacterial flocs or films are often the result of some kind of substrate limitation. ${ }^{85}$ Smith et al. ${ }^{95}$ showed for Mycobacterium sp. that the physiology of immobilized and suspended cells was not different in case there was no transport limitation. Only in a few models systemindependent parameters have been used. Monbouquette et al. ${ }^{96}$ and De Gooijer et al..$^{24}$ used kinetic parameters of the suspended cells and assumed that effects on these parameters are only determined by diffusion which is accounted for in the model. On the other hand, kinetic parameters seldomly have been determined under the extreme limiting conditions as existing in the deeper shells of immobilized cells. Wijffels et al. ${ }^{121}$ simulated starvation conditions in the deeper shells by estimation of the specific degradation rate, by growing the cells in a batch culture, depleting the medium from oxygen after some time and measuring the activity reduction as a function of time. This does, however, not indicate whether cells are indeed dead or in a dormant state..$^{16,67,76}$ The viable fraction of immobilized cells may be critical in predicting long-term or steady-state reactor performance ${ }^{19}$ and for the estimation of the dynamics of the system. 


\section{Physical parameters of the support}

Within the support material substrate will be transferred by diffusion. The rate of diffusion depends on the diffusion coefficient of the substrate in the support and the effect of the presence of large amounts of biomass on this diffusion coefficient. Effective diffusion coefficients for oxygen and other compounds have been determined for most support materials. ${ }^{28,119,123}$ Indeed it has been shown that cells may have an effect on the diffusion coefficients. For instance, Sakaki et al..$^{87}$ and Sun et al. ${ }^{99}$ showed that with increasing cell densities diffusion coefficients decreased. For this reason biomass-concentration-dependent diffusion coefficients have been used. ${ }^{24,66}$ Another possibility is to assume two diffusion coefficients, one for the gel itself and one for the micro-colonies. Within closely packed aggregates of bacterial cells the effective diffusion coefficient is between 20 and $30 \%$ of the value in media. ${ }^{35.58 .119}$ In case of the use of colony-expansion models ${ }^{36.124}$ both diffusion coefficients are introduced separately.

\section{Hydrodynamic-dependent physical parameters}

In processes with immobilized cells substrate is transferred from the liquid phase to the solid phase in which the reaction occurs. In many studies the diffusion of substrate through the solid phase was assumed to be the rate-limiting step in the process, because the thickness of the stagnant layer surrounding the solid particles was supposed to be much smaller than the radius of the gel bead used as a support for the immobilized cells. Furthermore, the diffusion coefficient in the support is usually smaller than in water. Usually, however, a relatively thin layer of biomass will be formed just beneath the support surface. If for example, oxygen is the limiting substrate, this active layer will be in the order of $100 \mu \mathrm{m}$, which is the same order of magnitude as the thickness of the stagnant layer. Sensitivity analysis of the parameters showed that the value of the external mass transfer coefficient, $k_{l, s}$, significantly influenced the overall consumption rate in such an immobilized-cell process. ${ }^{24}$ Relatively little is known, however, about external mass transfer in bioreactors as the relative velocity of the particles is generally not known. The relations used are based on empirical equations and need not only to be adapted for all types of bioreactors used, but also for all scales and procedures. 
Liquid/solid mass-transfer descriptions are often based on the film theory, in which the liquid-bulk phase is assumed to be perfectly mixed except for a thin, stagnant, layer surrounding the particles. It is assumed that mass transfer across this layer solely occurs by diffusion.

Mass transfer across the stagnant layer can thus be described by:

$$
J_{m}-\frac{D_{1}}{8}\left(C_{b}-C_{s}\right)
$$

As $\delta$ is generally not known, a liquid/solid mass-transfer coefficient, $k_{1, s}$, which can be calculated with the dimensionless Sherwood number, is defined as:

$$
k_{l, 8}=\frac{D_{1}}{\delta}-\frac{S h D_{1}}{d_{p}}
$$

Correlations for the Sherwood number are partly theoretical and partly empirical. For a sphere surrounded by an infinitely extended stagnant medium it can be derived that Sh equals 2. If the liquid starts to flow, the value of $S h$ increases. In that situation the stagnant region is limited to the near surroundings of the bead. The thickness of that stagnant layer, $\delta$, decreases as the flow increases, while $k_{t, s}$ and $S h$ increase. The general form of the Sherwood equation is:

$$
S h-2+\alpha S c^{\beta} R \theta^{\gamma}
$$

The dependence of the Sherwood number of the Schmidt and Reynolds numbers is usually described by empirical correlations.

Wijfels et al. ${ }^{121}$ calculated the liquid/solid mass-transfer coefficient by assuming that the particles move with the rate of free fall. In this case the Reynolds number was calculated from the Galileo number. ${ }^{7}$ At lower Reynolds numbers $(R e<30)$ the relation of Brian and Hales ${ }^{10}$ can be used. Whether this assumption is appropriate is not without doubt, because the experiments were executed in an air-lift loop reactor to which gas is supplied and where the volume fraction of beads was $15 \%$. This means that the particle movement is influenced by the turbulent flow in the reactor and is hindered because of the high particle concentration.

Another approach is Kolmogoroff's theory of local isotropical turbulence. ${ }^{60,88,118}$ 
Turbulence in air-lift loop reactors is caused by the introduction of air. Air bubbles will expand as they rise. This isothermal expansion of the gas bubbles is the main source of power input in the reactor. The rising bubbles will generate large eddies, which in first instance cause large-scale mixing in the reactor. Fluid packages will be interchanged. Further mixing will occur because the initial large eddies scatter into smaller ones. Those larger eddies thus transfer their kinetic energy to the smaller ones which will scatter again and so on. This transfer of energy occurs in all directions and as eddy-generation proceeds the orientation of the eddies will be lost and turbulence becomes isotropic. Ultimately, the only information transferred from the large eddies to the very small ones is the energy which will finally be dissipated (by friction to heat) in the smallest eddies having a flow which is just laminar $(R e=1)$. On the basis of a dimension analysis the size of these smallest eddies can be derived and from that the Reynolds number of a spherical particle in an isotropic turbulent flow field can be defined: $:^{23,46,88,92,94}$

$$
R \theta-c\left(\frac{e d_{p}^{4}}{v^{3}}\right)^{\frac{1}{3}} \quad \text { for } \quad d_{p}>\lambda
$$

The difference between the so defined Reynolds number and the Reynolds number as used in the equations of Ranz and Marshal $\|^{80}$ and Brian and Hales ${ }^{10}$ is that it is dependent on the energy applied to the reactor and not on the density difference between solid and liquid phase, and the solid/liquid mass-transfer coefficient is thus a function of the superficial gas velocity. Sänger and Deckwer ${ }^{88}$ and Livingston and Chase ${ }^{50}$ showed that the superficial gas velocity has indeed an effect on liquid/solid mass transfer for suspended particles in bubble columns or air-lift reactors. To obtain a relation for Sh they implemented the 'Kolmogoroff' Reynolds number (Eq. 4) in equation 3 and fitted $\alpha, \beta$ and $\gamma$ to their experimental data. The relations obtained are, however, not generally applicable as they are restricted to the flow regimes, density differences between solid and liquid phase, particle radius and solid-hold up tested. 


\section{EVALUATION OF MODELS}

Models contribute significantly to the understanding of the process if simulations are evaluated experimentally. Biofilm or immobilized-cell models can be evaluated by comparing simulated and observed macroscopic substrate consumption rates (based on analyses in the bulk phase) and biomass and substrate concentration profiles (local measurements inside the film or support). In recent years much progress has been realized in local measurement techniques.

\section{Micro-sensors}

Micro-sensors are electrodes with a very small tip diameter (less than $10 \mu \mathrm{m}$ ). It is possible to penetrate biofilms with such electrodes and measure local concentrations with a high spatial resolution. As such, micro-sensors form an efficient tool to measure substrate concentration profiles over a biofilm, ${ }^{110}$ the macroscopic consumption rate of a film from the slope at the surface of the support, the liquid/solid mass-transfer coefficient, ${ }^{36}$ diffusion coefficients ${ }^{110}$ and intermediate products. Micro-sensors have been developed for oxygen, ${ }^{21.36 .81} \mathrm{pH}$, ammonia, nitrate ${ }^{22}$ and glucose. ${ }^{18}$

When immobilized-cell models are evaluated, micro-electrode techniques are an excellent tool to compare calculated profiles with measured profiles, ${ }^{124}$ although there are some limitations:

i) Flow conditions.

If gel beads with immobilized cells are cultivated in a reactor where the support is kept in suspension the flow conditions in the reactor and in the flow chamber where measurements are done need to be the same.

ii) Spatial resolution.

The position of the electrode tip is usually determined visually. The accuracy with which the location of the tip can be determined is often not sufficient as concentration profiles tend to be very steep. This problem may be solved by simultaneous measurement of the concentration profile and the optical density. ${ }^{57}$ The solid/liquid interface is then identified from the optical density profile.

Micro-electrode techniques have a surplus value in more complex systems where reactions occur in sequence. This is the case in most biofilms and in the coimmobilized systems that were used by Hunik et al. ${ }^{40}$ (Nitrosomonas europaea and 
Nitrobacter agilis) and Santos et al. ${ }^{99,90}$ (the magic bead concept for integrated nitrification and denitrification). Products are released which form the substrate of other organisms. These intermediate products are often not detectable by analysis of the bulk-liquid phase because they are only present in the subsurface shells of the support. By means of micro-electrodes these intermediate products can be analyzed.

\section{Biomass profiles}

Total biomass concentrations in biofilms are relatively easy to determine by scraping of the biofilm and analyzing the obtained suspension. ${ }^{13}$ Local concentrations in biofilms can be determined by slicing or dissolving biofilm shells. Masuda et al. ${ }^{63}$ used a microslicer to cut segments of a thickness of $10-50 \mu \mathrm{m}$. In the sliced films bacterial counts were executed. Shells can be dissolved from gel particles in which cell concentrations can be determined by cell counts or turbidity measurements. ${ }^{9,55,115} \mathrm{~A}$ drawback of this method is, that usually shells of a thickness larger than $50 \mu \mathrm{m}$ are obtained. As profiles tend to be very steep, a higher resolution than this is required.

More accurate methods have been developed for artificially immobilized cells. Ultrathin sections out of the centre of the beads are sliced and within these sections the volumetric fraction of colonies can be determined. ${ }^{12,40,62,121,123}$ Profiles can be quantified by image analysis. The coordinates of the centres and the radii of the colonies are determined in relation to the centre or the surface of the bead. ${ }^{124}$ For this analysis, the slices have to be very thin to prevent that colonies overlap.

Samples for image analysis usually are stained:

i) To increase contrast. General staining methods with e.g. toluidine blue are used. ${ }^{127,123}$

ii) To distinguish growing cells from non growing cells. Cell components or reactions which are related to cell growth are stained:

- ANA $^{66}$

- DNA synthesis ${ }^{51}$

- Addition of the yellow coloured dimethylthiazol salt which is transferred to MTT formazan which has a blue colour'

$-{ }^{35} \mathrm{~S} .{ }^{45} \mathrm{Immobilized}$ cells were stained with a $\beta$-emitting isotope ${ }^{35} \mathrm{~S}$ which was supplied in the form of sulphate and is incorporated in proteins during synthesis. Consequently, 
growth can be monitored as ${ }^{35} \mathrm{~S}$ activity. Biomass profiles were observed with a light microscope after exposure of the slices to an autoradiographic emulsion and development.

iii) To specify certain strains. Hunik et al. ${ }^{39}$ used a labelling technique with fluorescent antibodies to distinguish two species of immobilized cells. Two ultra-thin centre sections were labelled with antibodies. One with a rabbit antibody for Nitrosomonas and the other with a rabbit antibody for Nitrobacter. The rabbit antibodies were labelled with a goat antibody which was conjugated with fluorescein isothiocyanate (FITC). As a result fluorescent colonies were obtained.

Although the slicing methods used in combination with image analysis are more accurate than scraping or dissolving of shells, there are also some disadvantages. Samples have to be cut in thin slices $(<5 \mu \mathrm{m})$ to prevent overlap of the colonies. To be able to make such thin sections with a microtome the samples have to be embedded in a resin and usually chemical fixation is necessary. Shrinkage of the samples has been observed during preparation ${ }^{112}$ and this may affect the results obtained. More direct methods would improve the quality of the results.

Recently such a direct technique has been presented by Worden and Berry. ${ }^{129}$ They mounted a thin slab of gel containing immobilized cells on a microscope slide. One side of the slab was in contact with nutrient medium and growth of cells could be observed through a microscope. Except for being a direct technique, the technique of Worden and Berry ${ }^{129}$ is non-invasive as well, which means that it is possible to study the dynamics of the process.

\section{TOWARDS A RATIONAL REACTOR DESIGN}

The models presented describe the performance of the immobilized-cell particles or biofilms. Fig. 4 indicates that the immobilized-cell reactor is more than just the immobilized cells. In the bioreactor, factors like fluid mixing and transfer of oxygen from the gas to the liquid phase have to be considered as well. In order to form an 

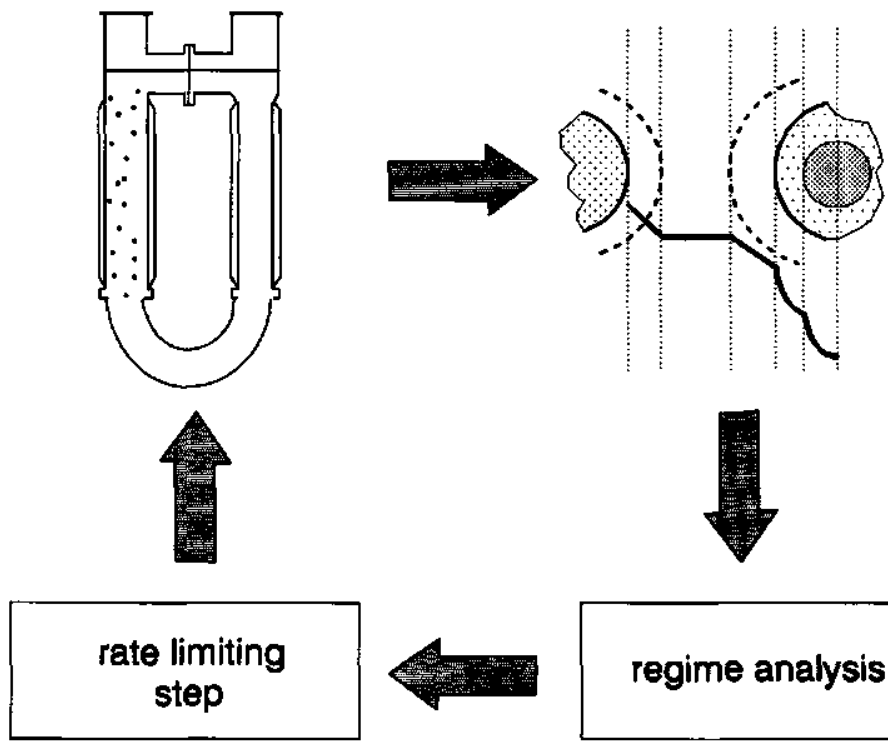

regime analysis

Fig. 7: Optimization of a process by determination of the rate-limiting step with regime analysis."

efficient tool for bioreactor design, the immobilized-cell models have to be integrated in a reactor model. It may be clear that many factors potentially affect the overall process. It would be too time consuming to give a complete description of the process. An efficient tool to account for all steps in a process of any scale forms regime analysis. With regime analysis the rate-limiting step can be determined and if possible, this step can be optimized in the process design (Fig. 7). Hunik et al..$^{41}$ performed this analysis for immobilized cells in air-lift loop reactors by determination of characteristic times of gas/liquid mass transfer, oxygen depletion in gas bubbles, liquid/solid mass transfer, mixing time and kinetics of the immobilized cells. For the latter, immobilized-cell models can be used. Hunik et $a l^{41}$ showed that for three different conditions of the nitrification process (under optimal conditions and under two extreme conditions, i.e. low temperatures and high substrate concentrations) the capacity was controlled by mass transfer of oxygen or ammonia and to a lesser extent by the conversion rates (text box). The regime analysis proved to be a helpful tool for the understanding of the entire process and for establishing the rate-limiting step. Design rules for different conditions can be obtained from the results of this regime analysis. 


\section{Rate-limiting step}

Hunik et al. ${ }^{41}$ showed that nitrification by immobilized cells was mainly controlled by mass transfer of oxygen. This is an improvement in comparison to the activated-sludge process, which is controlled by the specific growth rate. As a result, for the design of such a bloreactor the capacity of the process can be increased by increasing the rate of oxygen transport. The transfer of oxygen is dependent on the gas/liquid and liquid/solid mass-transfer coefficients and on the specific surface area of the different phases. Optimization of single parameters, however, does not necessarily mean that the capacity as a whole will be increased as other factors may be influenced as well. For example, an increase of the solid-phase hold up decreases gas/liquid mass transfer. ${ }^{114}$

\section{NOMENCLATURE}

$c=$ constant

$d_{\rho} \quad=$ particle diameter

$D_{1} \quad=$ diffusion coefficient in liquid phase

$J_{m} \quad=$ flux

$k_{l, s}=$ liquid/solid mass-transfer coefficient

Re $\quad=$ Reynolds number

$S_{b} \quad=$ substrate concentration in bulk liquid phase

$S_{z}=$ substrate concentration solid/liquid interphase

Sc $=$ Schmidt number

Sh = Sherwood number

$\alpha \quad=$ constant

$\beta \quad=$ constant

$\gamma \quad=$ constant

$\delta=$ thickness of stagnant layer

$\epsilon \quad=$ specific energy dissipation per unit of mass

$\lambda \quad=$ length scale of micro-scale eddy

$\nu \quad=$ kinematic viscosity 


\section{REFERENCES}

1. Al-Rubeai M., Spier R. (1989) Quantitative cytochemical analysis of immobilized hybridoma cells. Appl Microbiol Biotechnol 31: $430-433$

2. Annachatre A.P., Khanna P. (1987) Unsteady-state biofilm kinetics. J Env Eng 113: 429-433

3. Ariga O., Takagi H., Nishizawa H., Sano Y. (1987) Immobilization of microorganisms with PVA hardened by iterative freezing and thawing. J Ferment Technol 65 (6): 651-658

4. Barnes D., Bliss P.J. (1983) Biological control of nitrogen In wastewater treatment. E. \& F. Spon Ltd., London, $146 \mathrm{p}$

5. Benefield L., Molz F. (1985) Mathernatical simulation of a biofilm process. Biotechnol Bioeng 27: 921-931

6. Belser L.W. (1979) Population ecology of nitrifying bacteria. Ann Rev Microbiol 33: 309-333

7. Bird R.B., Stewart W.E., Lightfoot E.N. (1960) Transport phenomena. Wiley International edition, New York, $780 \mathrm{p}$

8. Black G.M. (1986) Characteristics and performance of immobilised cell reactors. In: Process engineering aspects of immobilised cell systems, eds. C. Webb, G.M. Black, B. Atkinson. The institution of chemical engineers, Warwickshire, 75-86

9. Boross L., Papp P., Szajáni B. (1990) Determination of the growth of gel-entrapped microbial cells at various depths of the alginate. In: Physiology of Immobilized Cells, Proceedings of an International Symposium held at Wageningen, The Netherlands, 10-13 December 1989, J.A.M. de Bont, J. Visser, B. Mattiasson, J. Tramper, Elsevier Science Publishers B.V., Amsterdam, 201-204

10. Brian P.L.T., Hales H.B. (1969) Effects of transpiration and changing diameter on heat and mass transfer to spheres. AlChE Journal 14: 419-425

11. Bryers J.D. (1988) Modeling biofilm accumulation. In: Physiological models in microbiology, vol. 2. Eds. M.J. Bazin, J.I. Prosser. CRC Press Inc., Florida, 109-144

12. Burrill H.N., Bell L.E., Greenfield P.F., Do D.D. (1983) Analysis of distributed growth of Saccharomyces cerevisiae cells immobilized in polyacrylamide gel. Appl Environm Microbiol 46: 716-721

13. Capdeville B., Nguyen K.M., Rols J.L. (1992) Biofilm modelling: structural, reactional and diffusional aspects. In: Blofilms-Science and Technology. Eds. L.F. Melo, T.R. Bott, M. Fletcher, B. Capdeville. Kluwer Academic Publishers, the Netherlands, 251-276

14. Characklis W.G., Turakhia M.H., Zelver N. (1989) Transport and Interfacial transfer phenomena. In: Biofilms. Eds. W.G. Characklis, K.C. Marshafl. John Wiley, New York, pp 265-340

15. Chen G.H., Ozaki H., Terashima Y. (1989) Modelling of the removal of organic substances and nitrogen in a biofilm. Wat Sci Tech 21: 791-804

16. Chesbro W. (1988) The domains of slow bacterial growth. Can J Microbiol 34: 427-435

17. Christensen F.R., Kristensen G.H., Jansen J.L.C. (1991) Biofilm structure - an important and neglected parameter in waste water treatment. Wat Sci Tech 21: 805-814

18. Cronenberg C., Van Broen B., De Beer D., Van Den Heuvel H. (1991) Oxygen-dependent 
glucose microsensor based on glucose oxidase. Analytica Chimica Acta 242: 275-278

19. Dale M.C., Chen C., Okos M.R. (1990) Cell growth and death rates as factors in the long-term performance, modeling, and design of immobilized cell reactors. Biotechnol Bioeng 36: 983-992

20. Dalili M., Chau P.C. (1987) Intraparticle diffusional effects in immobilized cell particles. Appl Microbiol Biotechnol 26: 500-506

21. De Beer D., Van Den Heuvel J.C. (1988) Gradients in immobilized biological systems. Analytica Chimica Acta 213: 259-265

22. De Beer D., Van Den Heuvel J.C., Ottengraf S.P.P. (1993) Microelectrode measurements of the activity distribution in nitrifying bacterial aggregates. Appl Environm Microbiol 59: 573-579

23. Deckwer W.D. (1980) Physical transport phenomena in bubble column bloreactors-ll. llquid-solid mass transfer, heating and heat transfer. In: eds: M. Moo-Young, C.W. Robinson, C. Vezina, Advances in Biotechnology. Proc. 6th Int. Ferment. Symposium London, Pergamon Press, Toronto 1: $471-476$

24. De Gooijer C.D., Wijfels R.H., Tramper J. (1991) Growth and substrate consumption of Nitrobacter aglis cells immobilized in carrageenan: part 2. dynamic modeling. Biotechnol Bioeng 38: 224-231

25. De Gooljer C.D., Wijffels R.H., Tramper J. (1992) Dynamic modeling the growth of immobilized nitrifying bacteria: biofilm development. In: Biofilms-Science and Technology. Eds. L.F. Melo, T.R. Bott, M. Fletcher, B. Capdeville. Kluwer Academic Publishers, the Nethertands, 291-296

26. Denac M., Uzman S., Tanaka H., Dunn I.J. (1983) Modeling of experiments on biofilm penetration effects in a fluidized bed nitrification reactor. Biotechnol Bioeng 25: 1841-1861

27. Dhulster P., Barbotin J.N., Thomas D. (1984) Culture and bioconversion use of plasmid-harbouring strain of immobilized E. coli. Appl Microbiol Biotechnol 20: 87-93

28. Estapé D., Godia F., Sola C. (1992) Determination of glucose and ethanol effective diffusion coefficients in Ca-alginate gel. Enzyme Microblol Technol 14: 396-401

29. Focht D.D., Verstraete W. (1977) Biochemical ecology of nitrification and denitrification. In: Advances in Microbial Ecology, ed. M. Alexander 1 Plenum Press, New York, p 135-214

30. Grady C.P.L., Lim H.C. (1980) Biological wastewater treatment; theory and applications. Marcel Dekker Inc., New York, p 787-831

31. Grady C.P.L. (1983) Modeling of biological fixed films-a state of the art review. In: Fixed film biological processes for wastewater treatment, eds. Y.C. Wu, D. Smith, Noyes Data Corporation, Park Ridge, New Jersey, p 75-133

32. Harremoës P. (1978) Biofilm kinetics. In: Water pollution microbiology 2, ed. R. Mitchell. John Wiley \& Sons, New York, p 71-109

33. Harremoes P. (1982) Criteria for nitrification in fixed film reactors. Wat Sci Tech 14: 167-187

34. Heijnen J.J., Mulder A., Weltevrede R., Hols J., Van Leeuwen H.L.J.M. (1991) Large scale anaerobic-aerobic treatment of complex industrial waste water using biofilm reactors. Wat Sci Tech 23: $1427-1436$

35. Ho C.S., Ju L-K. (1988) Effect of microorganisms on oxygen diffusion coefficients and solubilities 
In fermentation media. Biotechnol Bioeng 32: 313-325

36. Hooijmans C.M., Geraats S.G.M., Potters J.J.M., Luyben K.Ch.A.M. (1990) Experimental determination of mass transfer boundary layer around a spherical biocatalyst particle. Chem Eng J 44: B41-B46

37. Hulst A.C., Tramper J., Van 't Riet K., Westerbeek J.M.M. (1985) A new technique for the production of immobilized biocatalyst in large quantities. Biotechnol Bioeng 27: 870-876

38. Hunik J.H., Tramper J. (1993) Large-scale production of $\alpha$-carrageenan droplets for gel beads production: theoretical and practical limitations of size and production rate. Blotechn Progr 9: 186192

39. Hunik J.H., Van Den Hoogen M.P., De Boer W., Smit M., Tramper J. (1993) Quantitative determination of the spatial distribution of Nitrosomonas europaea and Nitrobacter agills cells immobilized in k-carrageenan get beads by a fluorescent-antibody labelling technique. Appl Environm Microbiol 9: 1951-1954

40. Hunik J.H., Bos C.G., Van Den Hoogen P., De Gooljer C.D., Tramper J. (1994) Co-immobilized Nitrosomonas europaea and Nitrobacter agilis cells: validation of a dynamic model for simultaneous substrate conversion and growth in k-carrageenan gel beads. Accepted for publication in Biotechnol Bioeng

41. Hunik J.H., Tramper J., Wijffels R.H. (1994) A strategy to scale-up nitrification processes with immobilized nitrifying cells. Accepted for publication in Biotechnol Progr

42. Inloes D.S., Taylor D.P., Cohen S.N., Michaels A.S., Robertson C.R. (1983) Ethanol production by Saccharomyces cerevisiae immobilized in hollow-fibre membrane bioreactors. Appl Env Microbiol 46: 264-278

43. Inloes D., Smith W., Taylor D., Cohen S., Michaels A.S., Robertson C.R. (1983) Hollow-fibre membrane reactors using immobilized $E$. coli for protein synthesis. Biotechnol Bioeng 25: 2653-2681

44. Jones W.L., Dockery J.D., Vogel C.R., Sturman P.J. (1993) Diffusion and reaction within porous packing media: a phenomenological model. Blotechnol Bioeng 41: 947-956

45. Karel S.F., Robertson C.R. (1989) Autoradiographic determination of mass-transfer limitations in immobilized cell reactors. Biotechnol Bioeng 34: 320-336

46. Kawase Y., Moo-Young M. (1990) Mathematical models for design of bioreactors: application of Kolmogoroff's theory of isotropic turbulence. Chem Eng J 43: B19-B41

47. Kokufuta E., Matsumoto W., Nakamura I. (1982) Immobilization of Nitrosomonas europaea cells with polyelectrolyte complex. Biotechnol Bioeng 24: 1591-1603

48. Kokufuta E., Yukishige M., Nakamura I. (1987) Coimmobilization of Nitrosomonas europaea and Paracoccus denitrificans cells using polyelectrolyte complex stabilized calcium alginate gel. $\mathrm{J}$ Ferment Technol 65: 659-664

49. Kokufuta E., Shimohashi M., Nakamura I. (1988) Simultaneously occurring nitrification and denitrification under oxygen gradient by polyelectrolyte complex-coimmobilized Nitrosomonas europaea and Paracoccus denitrificans cells. Biotechn Bioeng 31: $382-384$ 
50. Kuenen J.G., Robertson L.A. (1988) Ecology of nitrification and denitrification. Symp. Soc. Gen. Microbiol., 42nd nitrogen sulphur cycles, 161-218

51. Kuhn R.H., Peretti S.W., Ollis D.F. (1991) Micro fluorimetric analysis of spatial and temporal patterns of immobilized cell growth. Biotechnol Biceng 38: 340-352

52. LaMotta E.J. (1976) Internal diffusion and reaction in biological films. Environm Sci Techn 10: $765-769$

53. LaMotta E.J., Shieh W.K. (1979) Diffusion and reaction in biological nitrification. J Environm Eng Div 105 (EE4): 655-671

54. Larreta Garde V., Thomasset B., Barbotin J.N. (1981) Electron microscopic evidence of an immobilized living cell system. Enzyme Microb Technol 3: 216-218

55. Lefebvre J., Vincent J.C. (1992) Dynamic simulations of cell-bearing membranes: modelling and optimization of bioreactors. European Symposium on Computer Aided Process Engineering 2, 5-7 October 1992, Toulouse, France, Supplement to Computers and Chemical Engineering 17, Pergamon Press, S221-\$226

56. Lewandowakl Z., Bakke R., Characklis W.G. (1987) Nitrification and autotrophic denitrification in calcium alginate beads. Wat Sci Tech 19: 175-182

57. Lewandowski Z., Walser G., Characklis G. (1991) Reaction kinetics in biofilms. Biotechnol Bioeng 38: 877-882

58. Libicki S.B., Salmon P.M., Robertson C.P. (1988) The effective diffusive permeability of a nonreacting solute in microbial cell aggregates. Biotechnol Bioeng 32: 68-85

59. Lim J.H.F., Davies G.A. (1990) A stochastic model to simulate the growth of anchorage dependent cells on flat surfaces. Biotechnol Bioeng 36: 547-562

60. Livingston A.G., Chase H.A. (1990) Liquid-solid mass transfer in a three phase draft tube fluidized bed reactor. Chem Eng Comm 92: 225-244

61. Macdonald R.M. (1986) Nitrification in soil: an introductory history. In: Nitrification, ed.: J.I. Prosser, IRL Press, Oxford, Washington DC. pp 1-16

62. Marin-Iniesta F., Nasri M., Dhulster P., Barbotin J.N., Thomas D. (1988) Influence of oxygen supply on the stability of recombinant plasmid pTG201 in immobilized E. coli cells. Appl Microbiol Biotechnol 28: 455-462

63. Masuda S., Watanabe Y., lshiguro M. (1991) Biofilm properties and simultaneous nitrification and denitrification in aerobic biological contactors. Wat Sci Tech 23: 1355-1363

64. Mattiasson B., Ramstorp M., Nilsson I., Hahn-Hagerdal B. (1981) Comparison of the performance of a hollow fibre microbe reactor with a reactor containing alginate entrapped cells, denitrification of water using Pseudomonas denitrificans. Biotechnol Letters 3: 561-566

65. McLaren A.D. (1971) Kinetics of nitrification in soil: growth of the nitrifiers. Soil Sci Soc Amer Proc 35: $91-95$

66. Monbouquette H.G., Sayles G.D., Ollis D.F. (1990) Immobilized cell biocatalyst activation and pseudo-steady-state behavior: model and experiment. Biotechnol Bioeng 35: 609-629

67. Morita R.Y. (1988) Bioavailability of energy and its relationship to growth and starvation survival 
in nature. Can J Microbiol 34: 436-441

68. Myoga H., Asano H., Nomura Y., Yoshida H. (1991) Effects of immobilization conditions on the nitrification treatability of entrapped cell reactors using PVA freezing method. Wat Sci Tech 23: 1117-1124

69. Nakasaki K., Murai T., Aklyama T. (1989) Dynamic modeling of immobillzed cell reactor: application to ethanol fermentation. Biotechnol Bioeng 33: 1317-1323

70. Nilsson I., Ohlson S. (1982) Columnar denitrification of water by immobilized Pseudomonas denitrificans cells. Eur J Appl Biotechnol 14: $86-90$

71. Nilsson I., Ohlson S. (1982) Immobilized cells in microbial nitrate reduction. Appl Biochem Biotechnol 7: 39-41

72. Nilsson I., Ohlson S., Haggstrom L., Molin N., Mosbach K. (1980) Denitrification of water using immobilized Pseudomonas denitrificans cells. Eur J Appl Microbiol Biotechnol 10: 261-274

73. Osuga J., Mori A., Kato J. (1984) Acetic acid production by immobilized Acetobacter aceti cells entrapped in a $\kappa$-carrageenan gel. J Ferment Technol 62: 139-149

74. Painter H.A. (1986) Nitrification in the treatment of sewage and waste-waters. In: Nitrification, ed.: J.I. Prosser, Society for general microbiology 20, p 185-211

75. Painter H.A. (1977) Microbial transformations of inorganic nitrogen. Prog Wat Tech 8 (4/5): 3-29

76. Pirt S.J. (1987) The energetics of microbes at slow growth rates: maintenance energies and dormant organisms. J Ferment Technol 65: 173-177

77. Poduska R.A., Andrews J.F. (1975) Dynamics of nitrification in the activated sludge process. JWPCF 47: 2599-2619

78. Prosser J.I. (1986) Experimental and theoretical models of nitrification. In: Nitrification. ed. J.I. Prosser. Society for general Microbiology 20, 63-78

79. Prosser J.I. (1989) Autotrophic nitrification in bacteria. Advances in Microbial Physiology 30: 125181

80. Ranz W.E., Marshall W.R. (1952) Evaporation from drops, part II. Chem Eng Progr 48: 173-180

81. Revsbech N.P., Ward D.M. (1980) Oxygen microelectrode that is insensitive to medium chemical composition: use in an acid microbial mat dominated by Cyanidium caldarium. Appl Environm Microbiol 45: 755-759

82. Rittmann B.E., McCarty L. (1981) Substrate flux into biofilms of any thickness. J Environm Eng 107 (EE4): 831-849

83. Rittmann B.E. (1989) Detachment from biofilms. In: W.G. Characklis, P.A. Wilderer. Structure and function of biofilms, Dahlem Conference. John Wiley \& Sons, 49-58

84. Rittmann B.E. (1987) Aerobic biological treatment. Env Sci Technol 21: 128-136

85. Rouxhet P.G., Mozes N. (1990) The micro-environment of immobilized cells: critical assessment of the influence of surfaces and local concentrations. Physiology of Immobilized Cells, Proceedings of an International Symposium held at Wageningen, The Netherlands, 10-13 December 1989, J.A.M. de Bont, J. Visser, B. Mattiasson, J. Tramper, Elsevier Science Publishers B.V., Amsterdam, 343-354 
86. Salmon P.M. (1989) Mass transport phenomena in reactors containing entrapped enzymes or bacterial cells. PhD thesis Stanford University, USA

87. Sakaki K., Nozawa T., Furusaki S. (1988) Effect of intraparticle diffusion in ethanol fermentation by Immobllized Zymomonas mobilis. Biotechnol Bioeng 31: 603-606

88. Sänger P., Deckwer W.D. (1981) Liquid-solid mass transfer in aerated suspensions. Chem Eng J 22: $179-186$

89. Santos V.A., Tramper J., Wijflels R.H. (1992) Integrated nitrification and denitrification with immobilized microorganisms. In: Biofilms-Science and Technology. Eds. L.F. Melo, T.R. Bott, M. Fletcher, B. Capdeville. Kluwer Academic Publishers, the Netherlands, p 449-453

90. Santos V.A., Tramper J., Wijffels R.H. (1993) Simultaneous nitrification and denitrification using immobilized microorganisms. Biomat Art Cells \& Immob Biotech 21 (3): 317-322

91. Schmidt E.L. (1982) Nitrification in soil. In: Nitrogen in Agricultural Soils, ed. R.C. Dinauer, K.E. Gates, M. Stelly, F.J. Stevanson, J.M. Bremner, R.D. Hauck, D.R. Keeney Agronomy 22, Madison, Wisconsin USA, p 253-288

92. Shah Y.T., Kelkar B.G., Godbole S.P., Deckwer W.D. (1982) Design parameters estimations for bubble column reactors. AIChE Journal 28: 353-379

93. Sharma B., Ahlert R.C. (1977) Nitrification and nitrogen removal. Water Research 11: 897-925

94. Shinnar R., Church J.M. (1960) Statistical theories of turbulence in predicting particle size in agitated dispersions. Ind Eng Chem 52: 253-256

95. Smith M.R., De Haan A., De Bont J.A.M. (1993) The effect of calcium alginate entrapment on the physiology of Mycobacterium sp. strain E3. Appl Microblol Blotechnol 38: 642-648

96. Stenstrom M.K., Poduska R.A. (1980) The effect of dissolved oxygen concentration on nitrification. Water Research 14: 643-649

97. Stenstrom M.K., Song S.S. (1991) Effects of oxygen transport limitation on nitrification in the activated sludge process. JWPCF 63: 208-219

98. Stewart P.S., Robertson C.R. (1989) Microblal growth in a fixed volume: studies with entrapped Escherichia coli. Appl Microbld Biotechnol 30: 34-40

99. Sun Y., Furusaki S., Yamauchi A., Ichimura K. (1989) Diffusivity of oxygen into carriers entrapping whole cells. Biotechnol Biceng 34: 55-58

100. Tada M., Kimata T., Mori N., Emori H. (1990) Nitrogen removal systems using immobilized microorganisms in synthetic resin. Hitachi Review 39 (6): 379-386

101. Tanaka H., Uzman S., Dunn I.J. (1981) Kinetics of nitrification using a fluidized sand bed reactor with attached growth. Biotechnol Bioeng 23: 1683-1702

102. Tanaka K., Tada M., Kimata T., Harada S., Fujii Y., Mizuguchi T., Mori N., Emori H. (1991) Development of new nitrogen removal system using nitrifying bacteria immobilized in synthetic resin pellets. Wat Sci Tech 23: 681-690

103. Taxis du Poöt P., Dhulster P., Barbotin J.N., Thomas D. (1986) Plasmid stability and biomass production: comparison between free and immobilized cell cultures of Escherichia coll BZ18(pTG201) without selection pressure. J Bacteriol 165: 871-877 
104. Taxis du Poët P., Arcand Y, Bernier R., Barbotin J.N., Thomas D. (1987) Plasmid stability in immobilized and free recombinant Escherichia coll JM105(pKK223-200): importance of oxygen diffusion, growth rate, and plasmid copy number. Appl Environm Microbiol 53: 1548-1555

105. Toda K., Sato K. (1985) Simulation study on oxygen uptake rate of immobilized growing microorganisms. J Ferment Technol 63: 251-258

106. Tramper J., De Man A.W.A. (1986) Characterization of Nitrobacter agilis immobilized in calclum alginate. Enzyme Microb Technol 8: 472-476

107. Tramper J., Grootjen D.R.J. (1986) Operating performance of Nitrobacter agills immobilized in carrageenan. Enzyme Microb Technol 8 477-480

108. Tramper J. (1987) Nitrification and denitrification by immobilized viable cells. In: Enzyme Engineering 8, ed. A.l. Laskin, L. Mosbach, D. Thomas, L.B. Wingard Annuals of the New York Academy of Sciences 501: 362-366

109. Trulear M.G., Characklis W.G. (1982) Dynamics of biofilm processes. JWPCF 54: 1288-1301

110. Van Den Heuvel J.C., De Beer D., Cronenberg C.C.H. (1992) Microelectrodes: a versatile tool in biofilm research. In: Biofilms-Science and Technology. Eds. L.F. Melo, T.R. Bott, M. Fletcher, B. Capdeville. Kluwer Academic Publishers, the Netherlands, p 631-644

111. Van Ginkel C.G., Tramper J., Luyben K.Ch.A.M., Klapwijk A. (1983) Characterization of Nitrosomonas europaea immobilized in calcium alginate. Enzyme Microb Technol 5: 297-303

112. Van Neerven A.R.W., Wijfels R.H., Zehnder A.J.B. (1990) Scanning electron microscopy of immobilized bacteria in gel beads: a comparative study of fixation methods. $J$ Microbid Methods 11: $157-168$

113. Venkatasubramanian K., Karkare S.B., Vieth W.R. (1983) Chemical engineering analysis of immobilized-cell systems. Appl Biochem Bioeng 4: 311-349

114. Verlaan P. (1987) Modelling and characterization of an air-lift loop bioreactor. PhD. thesis. Wageningen Agricultural University, The Netherlands

115. Walsh P.K., Brady J.M., Malone D.M. (1993) Determination of the radial distribution of Saccharomyces cerevisiae immobilised in calcium alginate gel beads. Biotechnol Techn 7 (6): 435-440

116. Wanner O., Gujer W. (1984) Competition in biofilms. Wat Sci Tech 17: 27-44

117. Wanner O., Gujer W. (1986) A multispecies blofilm model. Biotechnol Bioeng 28: 314-328

118. Wagner K., Hempel D.C. (1988) Biodegradation by immobilized bacteria in an airlift-loop reactor: influence of biofilm diffusion limitation. Blotechnol Bioeng 31: 559-566

119. Westrin B.A., Axelsson A. (1991) Diffusion in gels containing immobilized cells: a critical review. Biotechnd Bioeng 38: 439-446

120. Wijffels R.H., Tramper J. (1989) Performance of growing Nitrosomonas europaea cells immobilized in $\kappa$-carrageenan. Appl Microbiol Biotechnol 32: 108-112

121. Wijffels R.H., De Gooijer C.D., Kortekaas S., Tramper J. (1991) Growth and substrate consumption of Nitrobacter agilis cells immobilized in carrageenan: part 2. model evaluation. Biotechnol Bioeng 38: 232-240 


\section{Chapter 1}

122. Wijtels R.H., De Gooljer C.D., Schepers A.W., Beuling E.E., Mallé LR., Tramper J. (1994) Growth of Immobilized Nitrosomonas europaea: implementation of diffusion limitation over microcolonies. Submitted

123. Wijffels R.H., Englund G., Hunik J.H., Leenen E.J.T.M., Bakketun A., Günther A., Obón de Castro J.M., Tamper J. (1994) Effects of diffusion limitation on immobilized nitrifying microorganisms. Submitted

124. Wijffels R.H., Eekhof M.R., De Beer D., Van Den Heuvel J.C., Tramper J. (1994) Pseudosteady-state oxygen concentration profiles in an agar slab containing growing Nitrobacter agilis. Submitted

125. Wijffels R.H., Schepers A.W., Smit M., De Gooijer C.D., Tramper J. (1994) Effect of initial biomass concentration on the growth of immobilized Nitrosomonas europaea. Submitted

126. Williamson K., McCarty P.L. (1976) A model of substrate utilization by bacterial films. JWPCF 48: 9-24

127. Williamson K., McCarty P.L. (1976) Verification studies of the biofilm model for bacterial substrate utilization. JWPCF 48: 281-296

128. Woodward J. (1988) Methods of immobilization of microbial cells. J Microbiol Methods 8: 91-102

129. Worden R.M., Berry L.G. (1992) The one-dimensional blocatalyst, a research tool for in situ analysis of Immobilized-cell biocatalysts. Appl Biochem Biotechnol 34/35: 487-498 


\section{INTERMEZZO}




\section{INTERMEZZO}

Nitrification is the conversion of ammonia to nitrate. It is an important step in the removal of nitrogen compounds in wastewater treatment.

In this thesis, nitrification by immobilized bacteria is studied. The bacteria are immobilized in solid beads which can be retained easily in a bioreactor. The advantage of using immobilized bacteria instead of suspended bacteria which are usually used for the treatment of wastewater is that the capacity is at least 20 times higher than in traditional systems. As a result compact treatment systems can be constructed which will become important in future generation treatment systems.

The process of nitrification with immobilized cells is modelled and the results are compared with actual measurements. In this way we obtained information about growth and substrate conversion by immobilized bacteria. This is not only valuable for the development of efficient nitrification reactors but for other reactors which contain immobilized bacteria as well.

Nitrosomonas europaea and Nitrobacter agilis are the nitrifying bacteria that were used in this study. Nitrosomonas converts ammonia into nitrite and Nitrobacter converts nitrite into nitrate. On the right page a scanning electron microscopic picture is shown of Nitrosomonas europaea cells. The bar length is $1 \mu \mathrm{m}$.

The nitrifying bacteria are immobilized in carrageenan. Carrageenan is a gel obtained from seewead and is soluble in the absence of potassium ions. By suspending bacteria in the carrageenan solution, and extruding them dropwise through a hollow needle, drops are formed. The drops gelate into solid beads with a diameter of about $2 \mathrm{~mm}$ when collected in a solution containing potassium. On the right page such a solid bead is shown. 


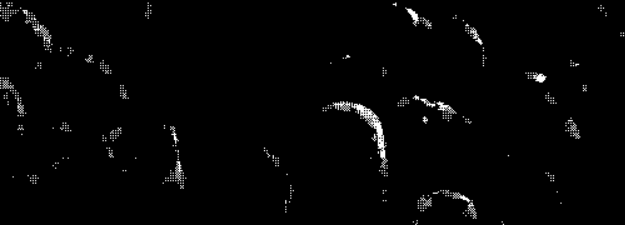

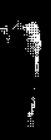

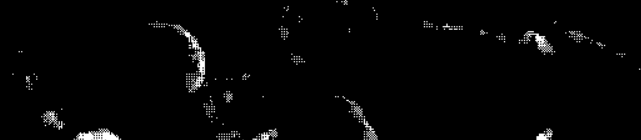

23

4

$y^{2+2}$

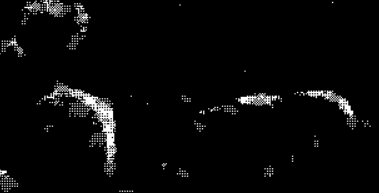

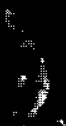<smiles>C[13CH][13CH][13CH]</smiles>

K

$4+4$
$+\infty$

(1)

A

$m^{-4}$

$(9), 7)$

Y

when

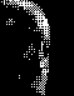

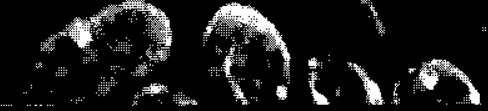

1

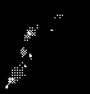

$r^{+m a n d s}$

(7)
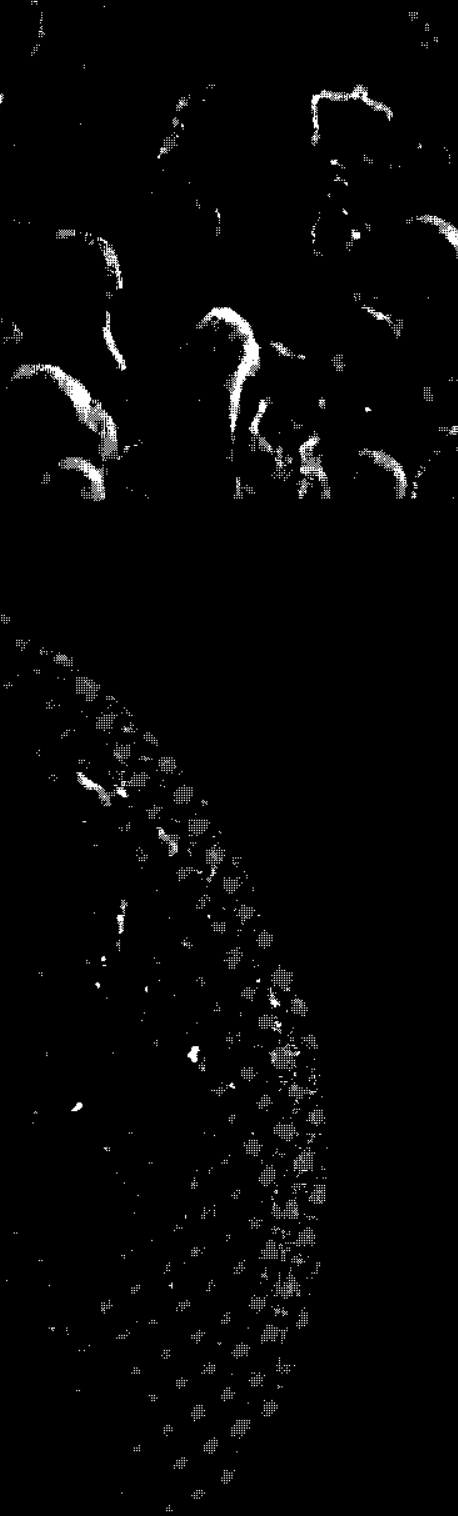
This chapter has been published in Applied Microbiology and Blotechnology 32 (1989) 108-112 by the authors R.H. Wijffels and J. Tramper

\title{
CHAPTER 2
}

\section{PERFORMANCE OF GROWING NITROSOMONAS EUROPAEA CELLS IMMOBILIZED IN CARRAGEENAN}

\begin{abstract}
Nitrosomonas europaea cells were immobilized in $x$-carrageenan. The performance of the immobilized cells was investigated in an air-lift loop reactor under wash-out conditions with respect to freely suspended cells. When fed with solutions of ammonia up to $16 \mathrm{mM}$, high substrate conversions were accomplished. Sudden increases in ammonium-ion concentration hardly influenced the conversion. Observations made by scanning electron microscopy showed that the immobilized cells were initially growing homogeneously across the beads, but as growth proceeded, a biomass density gradient developed, eventually resulting in a kind of biofilm.
\end{abstract}




\section{INTRODUCTION}

Removal of nitrogen compounds from waste waters is essential and often accomplished by biological processes..$^{10}$ The oxidation of ammonium to nitrite and nitrate ions, i.e. the nitrification step, in these biological processes is especially problematic because of the slow growth rate of the pertinent bacteria, which rapidly results in their wash-out from the treatment plant.

In earlier studies we have shown that the nitrifying cells can be retained in bioreactors by immobilization of these bacteria in a gel with maintenance of their nitrifying capacities. ${ }^{12,13,14,15,16,17}$ It has been demonstrated that in the case of immobilized Nitrosomonas europaea cells diffusion limitation increased as the amount of immobilized cells increased. ${ }^{17}$ It has also been demonstrated, for instance with Nitrobacter agilis ${ }^{16}$, that immobilized cells can grow in principle. Under substratelimiting conditions, the growth rate of the cells is higher when the substrate concentration is higher. Therefore, if diffusion limitation is involved, i.e. a significant substrate-concentration gradient exists, cells in the outer layers of the beads will grow faster and thus the substrate-concentration gradient becomes steeper and steeper, resulting in a biomass gradient. Eventually, according to this theory, this should result in a very dense biofilm in the outer layers of the beads. For mathematical modelling it is important to know whether the cells are homogeneously distributed or whether a biofilm can be assumed to exist.

The phenomenon of heterogeneous growth of immobilized cells has already been shown by several authors, for example with cells of Pseudomonas putida and Aspergillus niger ${ }^{7}$ Streptomyces aureofaciens, ${ }^{8}$ Saccharomyces carisbergensis ${ }^{19}$ and Saccharomyces cerevisiae, ${ }^{1,4,7}$ all immobilized in alginate or carrageenan. So far, in immobilized biocatalyst models a homogeneous distribution of the cells across the bead or the outer shell was assumed. ${ }^{3.4,5,6.8,11}$

In this paper the situation for Nitrosomonas europaea cells immobilized in carrageenan beads is qualitatively described and presently used as the foundation for a model in which growth and substrate flux are quantified. 


\section{MATERIALS AND METHODS}

Cultivation of the free and immobilized cells and the immobilization procedure were executed under aseptic conditions.

\section{Organism and culture conditions}

Cultivation of the Nitrosomonas europaea cells (ATCC 19718) was done in a chemostat culture, supplied (dilution rate $(D)=0.025 \mathrm{~h}^{-1}$ ) with a medium containing per $\mathrm{dm}^{3}$ of demineralized water: $25 \mathrm{mmol} \mathrm{NH}_{4} \mathrm{Cl} ; 2 \mathrm{mmol} \mathrm{NaCl} ; 1 \mathrm{mmol} \mathrm{MgSO}{ }_{4} ; 1$ $\mathrm{mmol} \mathrm{KCl} ; 1 \mathrm{mmol} \mathrm{CaCl} ; 2.5 \mathrm{mmol} \mathrm{NaH}_{2} \mathrm{PO}_{4} ; 2.5 \mathrm{mmol} \mathrm{Na}_{2} \mathrm{HPO}_{4}$ and a general micronutrient solution. The fermenter $\left(2 \mathrm{dm}^{3}\right)$ was operated at $30^{\circ} \mathrm{C}$, aerated, and the $\mathrm{pH}$ controlled at 7.5 with a $1 \mathrm{M} \mathrm{NaHCO}_{3}$ solution.

\section{Immobilization procedure}

When cells were needed for immobilization, the overflow of the chemostat was collected in an ice-cooled vessel (to conserve activity) for 2 or 3 days (to have a sufficient amount of cells). The cell suspension was harvested by centrifugation in a Sorvall RC2-B centrifuge (Wilmington, Del, USA) for 15 minutes, $16,300 \mathrm{~g}$ and $5^{\circ} \mathrm{C}$. The cells were washed with demineralized water.

A $\kappa$-carrageenan solution (Genugel X0828, A/S Kobenhavns Pektinfabrik, DK Lille Skensved) of about $4 \%$ in demineralized water was sterilized during 20 minutes, 110 ${ }^{\circ} \mathrm{C}, 2 \mathrm{~atm}$., and cooled to $35^{\circ} \mathrm{C}$. By adding the bacterial suspension the percentage of carrageenan was brought to $2.6 \%$. This mixture was extruded drop wise through a thin hollow needle into a $0.75 \mathrm{M} \mathrm{KCl}$ solution. The size of the drops was controlled by a water-saturated longitudinal air flow at an average diameter of $3.1 \mathrm{~mm}$. The beads were kept in the $\mathrm{KCl}$-solution during 2 hours. The immobilization set-up was temperature controlled at $30^{\circ} \mathrm{C}$. 


\section{Immobilized cell cultivation}

The immobilized cells were cultivated in an air-lift loop reactor of $1.3 \mathrm{dm}^{3}$ with an external loop (Fig. 1). The medium used for these experiments contained per $\mathrm{dm}^{3}$ of sterilized water: a variable concentration of $\mathrm{NH}_{4} \mathrm{Cl} ; 1 \mathrm{mmol} \mathrm{NaCl} ; 1 \mathrm{mmol} \mathrm{MgSO}$; 5.4

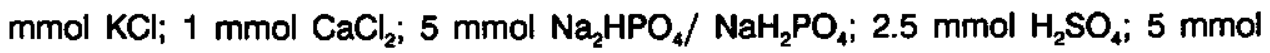
$\mathrm{NaHCO}_{3}$ and $1 \mathrm{~cm}^{3}$ of the micro-nutrient solution.

The volume fraction of immobilized particles in the reactor varied between 6 and $10 \%(v / v)$ in the various experiments.

A $D$ of 0.13-0.15 $\mathrm{h}^{-1}$ was applied, i.e. wash-out conditions for the free cells.

The air-lift loop reactor was operated at $30^{\circ} \mathrm{C}$ and the $\mathrm{pH}$ was controlled at 7.4 with a $0.1 \mathrm{M} \mathrm{KHCO}_{3}$ solution.

Fig. 1: Lab-scale air-lift loop reactor.

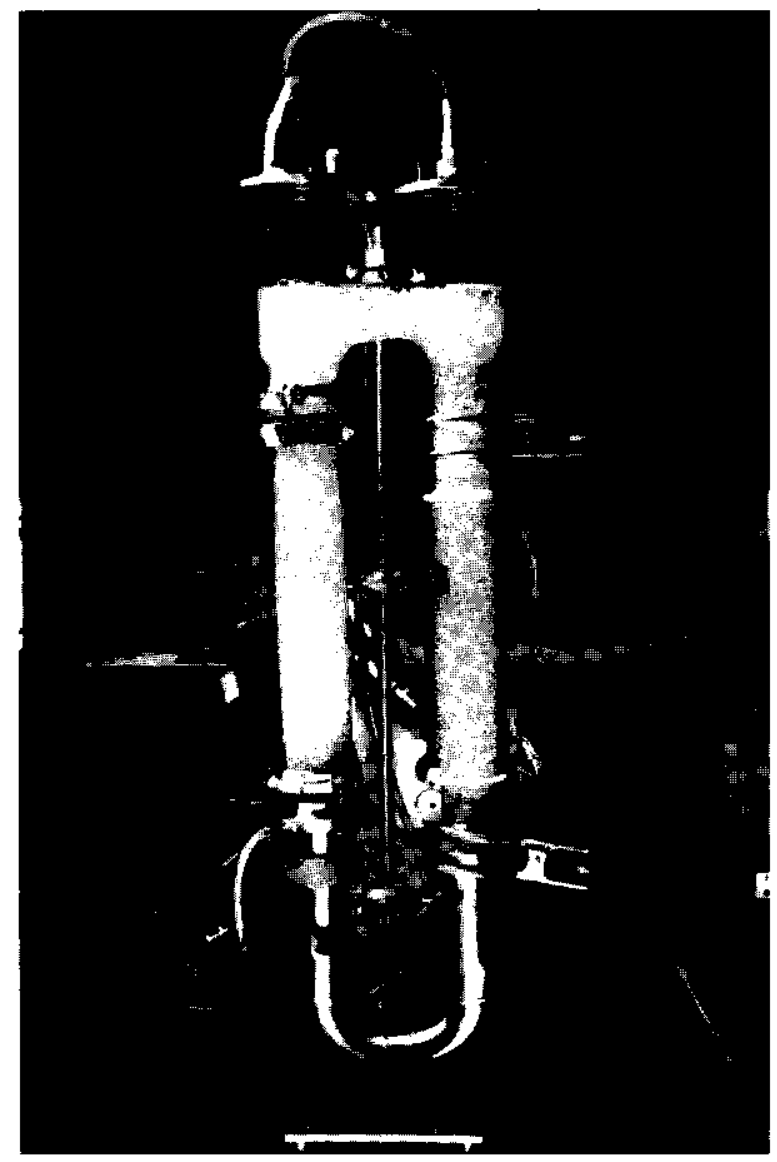




\section{Analytical methods}

Ammonia and nitrite were determined colorimetrically with Neissler reagent (Dutch Standard Methods: NEN 3235 6.1.11) and Griess Romijn and van Eck reagent (Dutch Standard Methods: NEN 3235 6.3.), respectively.

\section{Electron microscopic observation}

For observation of the beads by scanning electron microscopy (SEM) a comparative study of different techniques was made. ${ }^{18}$ The most suitable technique proved to be fixation with $2 \%$ glutaraldehyde in a buffer solution followed by a $1 \%$ osmiumtetroxide solution in the same buffer. The buffer contained $0.025 \mathrm{M} \mathrm{Na}$ cacodylate $(\mathrm{pH} \mathrm{6.8)}$ and $0.1 \mathrm{M} \mathrm{KCl}$. The samples were dehydrated stepwise using ethanol. In the first steps $\mathrm{KCl}$ was added to preserve the rigidity of the gel. The beads were broken after freezing them above liquid nitrogen and critical point dried in a Balzers CPD 10. After coating with gold in a vacuum evaporator Balzers SCD 028 (127 $V, 30 \mathrm{~mA}, 0.1$ bar), the samples were observed in a Jeol JSM $35 \mathrm{C}$ scanning microscope $(15 \mathrm{kV})$.

\section{RESULTS AND DISCUSSION}

In 3 separate experiments and at various ammonia concentrations the conversion (based on influent and effluent ammonia concentrations) was determined and observations with SEM were made in the steady states. The experiments were terminated as soon as technical problems prevented further reliable measurements.

Daily results of experiments 2 and 3 are given in Fig. 2 and 3 . The experiments were performed under sterile conditions to prevent infections with Nitrobacter cells. The results show that the only formed product was nitrite so Nitrobacter cells were excluded. The nitrite concentration of the effluent sometimes is higher than the ammonia concentration of the influent but always within the accuracy of the assay.

After start up of the first run the ammonium-ion conversion increased to $89 \%$ on the tenth day. In this experiment the conversion in only one steady state was determined. In the second experiment, the ammonium-ion conversion quickly 


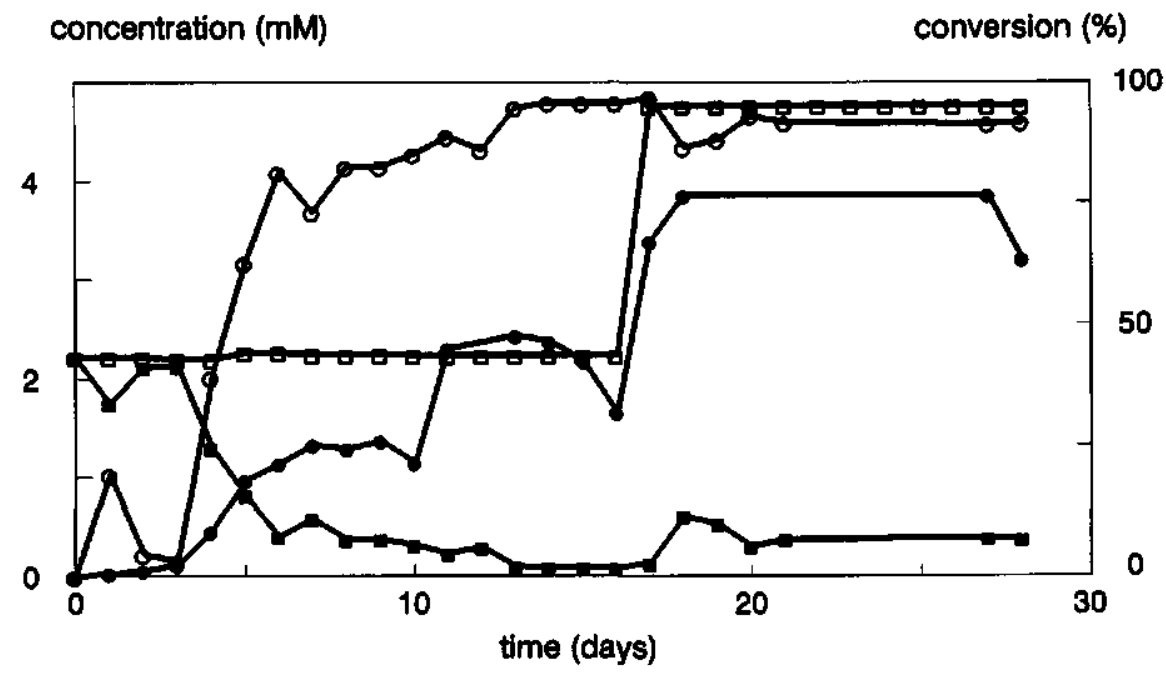

Fig. 2: Influent and effluent ammonia ( $\square$, $\square$ respectively) and effluent nitrite $(\Theta)$ concentrations and conversion $(O)$ in a growth experiment wht $8.85 \%$ gel; dilution rate $(D)=0.14 \mathrm{~h}^{-1}$.

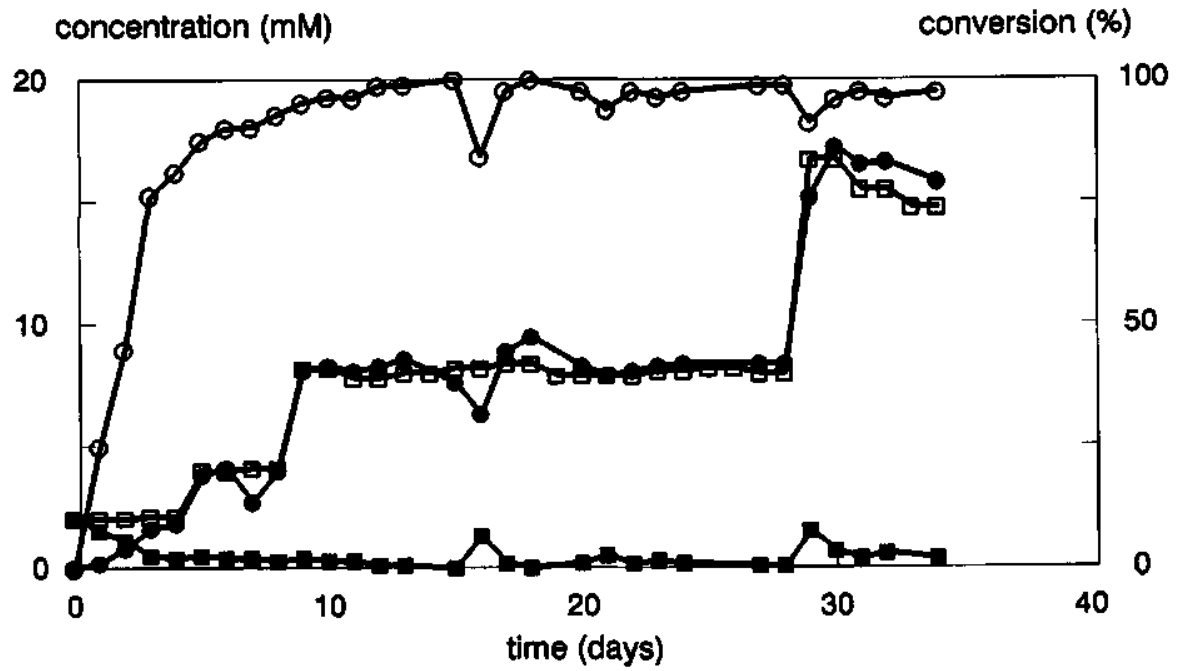

Fig. 3: Influent and effluent ammonia ( $\square$, 1 respectively) and effluent nitrite $(\Theta)$ concentrations and conversion $(O)$ in a growth experiment with $9.08 \%$ gel; dilution rate $(D)=0.15 \mathrm{~h}^{-1}$. 
increased to about $80 \%$ in the first six days (Fig. 2). The conversion eventually reached in the steady state was on average $96 \%$. After 17 days the ammonia concentration was doubled. The substrate concentration in the influent was then on average $4.8 \mathrm{mmol}^{\mathrm{dm}}$. The conversion kept its high level and only a slight temporary increase of the ammonium-ion concentration in the effluent was noticed initially. The conversion in the second steady state reached $92 \%$ in average.

In the third growth experiment, 4 days after start up, again an ammonium-ion conversion of about $80 \%$ was quickly reached. The ammonium-ion concentration in the influent was doubled 4 and 8 days after start-up. A steady average conversion of $97 \%$ was reached. The ammonium-ion concentration was further increased 28 days after start-up. The influent ammonium concentration was then on average $15.7 \mathrm{mmol}$. $\mathrm{dm}^{-3}$. The conversion decreased slightly only temporary and became constant again at $97 \%$.

The experiments show that immobilized Nitrosomonas europaea cells easily adapted to an increase in substrate concentration. This is analogous to the earlier results obtained using Nitrobacter agilis cells. ${ }^{16}$

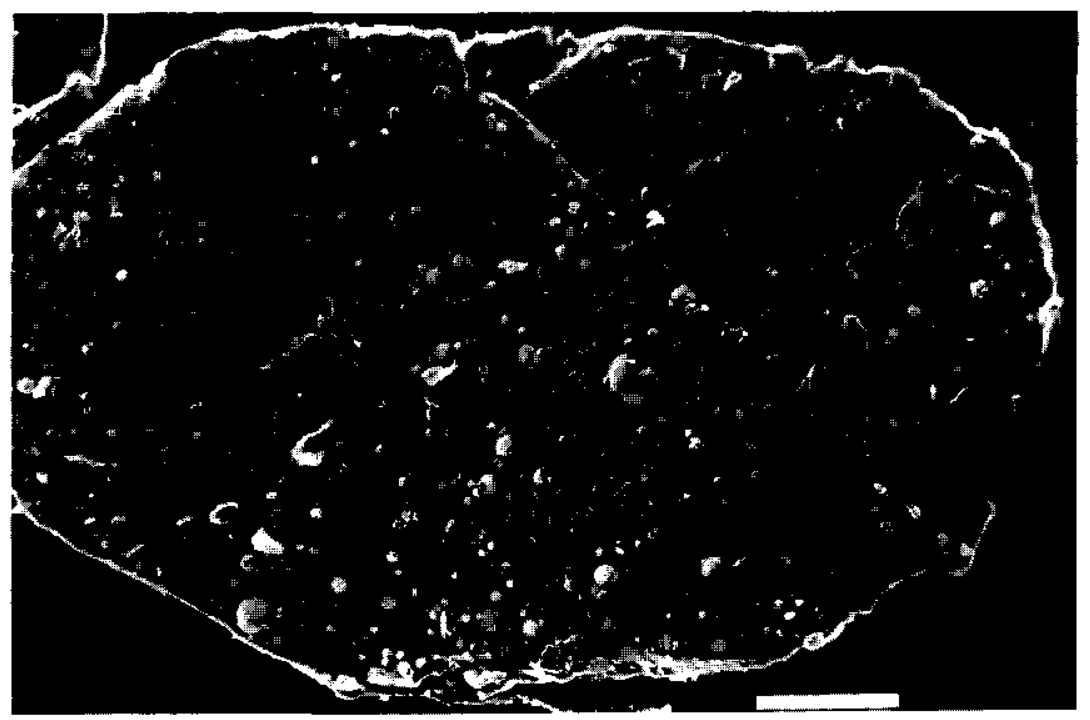

Fig. 4: Section of a carrageenan bead with micro-colonles of Nitrosomonas europaea 16 days after start-up; bar length $100 \mu \mathrm{m}$. 
In the second experiment, two samples were taken for observation by SEM, one at start-up and one on day 16 after the first steady state had been reached. The fresh immobilized cells appeared to be well distributed over the beads, all as single cells. After 16 days growth clearly had occurred (Fig. 4). The originally single cells had grown into micro-colonies that were homogeneously distributed over the gel bead. The biomass concentration was up to that time still relatively low, and thus the activity of the bead as a whole. Therefore, relatively little transport of substrate took place across the bead, needing only a small concentration gradient. This resulted in little radial differences in specific growth rate, explaining the still rather homogeneous distribution after 16 days.

In the third experiment samples were also taken for observation by SEM, in this case on days 6,28 and 32 . After 6 days the micro-colonies were not yet clearly visible. They were small and homogeneously distributed throughout the support. At day 28 , after feeding with an ammonium-ion concentration of about $8 \mathrm{mmol}^{\mathrm{dm}^{-3}}$ for a prolonged period, a different distribution appeared. Fig. 5 shows that the cells were more concentrated at the periphery of the beads and that the micro-colonies in the

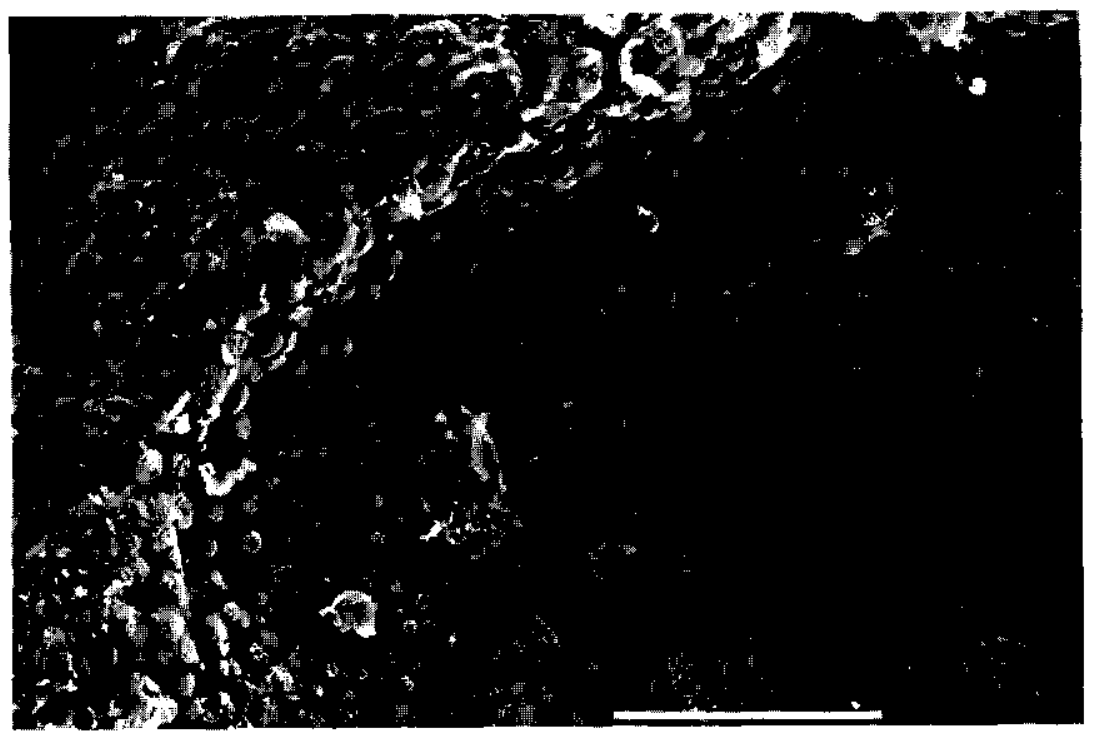

Fig. 5: Section of carrageenan bead with micro-colonies of Nitrosomonas europaea 28 days after start-up; bar length $100 \mu \mathrm{m}$. 
centre of the beads were small. That the micro-colonies are projected out of the surface was an artefact, because during preparation for SEM the carrageenan material shrank about $50 \%$ more than the bacteria. ${ }^{18}$ In the third steady state (after 32 days) the same observations were made. Figure 5 shows that a gradient in biomass density had indeed developed. Due to a heterogeneous specific growth rate, varying radially, the gradient in biomass density, apparently became steeper and steeper. Two periods in immobilized cell growth could thus be observed. In the first homogeneous growth was observed because there were no diffusional restrictions. In the second period there were diffusional restrictions which resulted in heterogeneous growth.

The situation as given in the Fig. 2 and 3 only apparently is reaching so quickly a steady state. It appeared to be a steady state situation because the substrate concentration in the reactor was constant, but in reality the biomass gradient was slowly developing, due to net growth in the outer layers and net starvation in the core. In this pseudo-steady state it is not possible that the very rapid adaptation to a doubling in substrate concentration in the influent was caused by a doubling of cell mass, because the maximum specific growth rate of Nitrosomonas europaea is very low $\left(\mu_{\max }=0.05 \mathrm{~h}^{-1}\right)$ and the substrate concentration in the reactor is far below the half saturation constant $\left(\mathrm{K}_{\mathrm{\delta}}=0.7 \mathrm{mmol} . \mathrm{dm}^{-3}\right)^{10}$

In the present experiments ammonia was clearly the rate-limiting substrate. It has to be, otherwise an increase of the ammonia concentration in the influent never could lead to such a rapid adaptation. Calculation of the Thiele moduli for ammonia and oxygen indicate that both substrates could give rise to some limitation. Normally oxygen is the only limiting substrate in aerobically grown cells, but in this case its $K_{s}$ value $\left(0.02 \mathrm{mmol}^{\left.-\mathrm{dm}^{-3}\right)}\right.$ was much lower than the concentration in the reactor $(0.10$ $\mathrm{mmol} . \mathrm{dm}^{-3}$ ). The ammonia concentration in the reactor, on the other hand, was lower than the $K_{s}$ value for Nitrosomonas europaea. As a consequence, an increase in feeding is merely adapted by an increase in specific growth rate, and thus substrate consumption rate, rather than by an increase in immobilized biomass concentration. As can be seen in Fig. 2 and 3 the level of the ammonia concentration in the effluent became higher (though still low) when the influent substrate concentration was increased. When the substrate concentration in the reactor is much higher than the $K_{s}$ value, the specific growth rate would be equal to the maximum specific growth rate and an increase in substrate concentration of the influent could only lead to an adaptation of the system by growth of the immobilized biomass as we have seen with 
immobilized denitrifying cells. ${ }^{20}$ However, in the first order regime of the Monod curve the adaptation is possible by an increase in the specific growth rate and is for that reason fast. Eventually this must lead to an increase in the immobilized biomass concentration and to the heterogeneous distribution as observed.

We are presently studying the various phenomena in more detail and quantitatively in order to derive to a mathematical model, enabling prediction of transient phenomena, steady states and maximum capacities.

\section{REFERENCES}

1. Beronio P.B., Jansen N.B., Tsao G.T., Bracker C.B. (1986) Analysis of the distribution of Saccharomyces cerevisiae immobilized in $\kappa$-carrageenan. American Chemical Society Meeting 7-12 Sept 1986, Anaheim, California, paper MBTD44

2. Chang H.N., Moo-Young M. (1988) Analysis of oxygen transport in immobilized whole cells. In: Moo-Young M. (ed) Bloreactor immobilized enzymes and cells fundamentals and applications. Elsevier, London, pp 33-51

3. Chang H.N., Moo-Young M. (1988) Estimation of oxygen penetration depth in Immobilized cells. Appl Microbiol Biotechnol 19: 107-112

4. Chibata I., Tose T., Fujlmura F. (1983) Immobilized Ilving microbial cells. In: Tsao G.T. (ed) Annual Reports on Fermentation Processes, vol. 6. Academic Press, London, pp 1-22

5. Dalili M., Chau P.C. (1987) Intraparticle diffusional effects in immobilized cell particles. Appl Microbiol Biotechnol 26: 500-506

6. De Gooijer C.D., Hens H.J.H., Tramper J. (1989) Optimum design for a series of continuous stirred tank reactors containing immobilized biocatalyst beads obeying intrinsic Michaelis-Menten kinetics. Bioprocess Eng 4: 153-158

7. Gosmann B., Rehm H.J. (1986) Oxygen uptake of microorganisms entrapped in Ca-alginate. Appl Microbiol Biotechnol 23: 163-167

8. Khang Y.H., Shankar H., Senatore F. (1988) Modeling the effect of oxygen mass transfer on B-lactam antibiotic production by immobilized Cephalosporium acremonium. Biotechnol Lett 10: 861-866

9. Mahmoud W., Rehm H.J. (1986) Morphological examination of immobilized Streptomyces aurofaciens during chlortetracycline fermentation. Appl Microbiol Biotechnol 23: 305-310

10. Painter H.A. (1977) Microbial transformations of inorganic nitrogen. Prog Water Technol 8: 3-29

11. Radovich J.M. (1985) Mass transfer effects in fermentations using immobilized whole cells. Enzyme Microb Technol 7: 2-10

12. Tramper J. (1985) Nitrification and denitrification by immobilized bacteria. Third European Congress on Biotechnology, vol. 4. 10-14 September 1984, Dechema, VCH, Weinheim, pp 363- 
368

13. Tramper J. (1987) Nitrlfication and denitrification by immobilized viable cells. In: Laskin A.I., Mosbach K., Thomas D., Wingard L.B. (eds) Enzyme Engineering, vol. 8. Ann. N. Y. Acad. Sci., New York, pp 362

14. Tramper J., Suwinska-Borowiec G., Klapwijk A. (1985) Characterization of nitrifying bacteria immobilized in calcium alginate. Enzyme Microb Technol 7:155-160

15. Tramper J., De Man A.W.A. (1986) Characterization of Nitrobacter agilis immobilized in calcium alginate. Enzyme Microb Techn 8: 472-476

16. Tramper J., Grootjen D.R.J. (1986) Operating performance of Nitrobacter agilis immobilized in carrageenan. Enzyme Microb Techn 8: 477-480

17. Van Ginkel C.G., Tramper J., Luyben K.Ch.A.M., Klapwijk A. (1983) Characterization of Nitrosomonas europaea immobilized in calcium alginate. Enzyme Microb Technol 5: 297-303

18. Van Neerven A.R.W., Wijffels R.H., Zehnder A.J.B. (1990) Scanning electron microscopy of immobilized bacteria in gel beads: a comparative study of fixation methods. $J$ Microbiol Meth 11: $157-168$

19. Wada M., Kato J., Chibata I. (1980) Continuous production of ethand using immobilized growing yeast cells. Eur J Appl Microbiol Biotechn 10: 275-287

20. Wijfels R.H., Schukking G., Tramper J. (1989) Characterization of a denitrifying bacterium immobilized in $\kappa$-carrageenan. Appl Microbiol Blotechnol 34: 399-403 


\section{INTERMEZZO}

Dropwise immobilization is a time-consuming technique. The capacity that can be reached with one needle is about $100 \mathrm{ml}$ per hour. For large-scale experiments and for eventual practical significance this is not sufficient. To speed up the production the resonance nozzle technique has been developed. A jet of gel is formed and subjected to a vibration. The vibration breaks up the jet into small droplets. This method allows 200-700 beads to be formed per second, which means a capacity per jet of 10 liters per hour. 


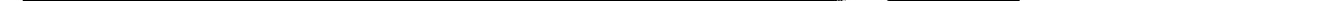


This chapter has been published in Biotechnology and Bicengineering 38 (1991) 224-231 by the authors C.D. de Gooijer, R.H. Wijffels and J. Tramper

\title{
CHAPTER 3
}

\section{GROWTH AND SUBSTRATE CONSUMPTION OF NITROBACTER AGILIS CELLS IMMOBILIZED IN CARRAGEENAN: PART 1. DYNAMIC MODELLING}

\begin{abstract}
The modelling of the growth of Nitrobacter agilis cells immobilized in $\kappa$-carrageenan is presented. A detailed description is given of the modelling of internal diffusion and growth of cells in the support matrix in addition to external mass transfer resistance. The model predicts the substrate and biomass profiles in the support as well as the macroscopic-oxygen consumption rate of the immobilized biocatalyst in time. The model is tested by experiments with continuously operated air-lift loop reactors, containing cells immobilized in $\kappa$-carrageenan. The model describes experimental data very well. It is clearly shown that external mass transfer may not be neglected. Furthermore, a sensitivity analysis of the parameters at their values during the experiments revealed that apart from the radius of the spheres and the substrate bulk concentration, the external mass transfer resistance coefficient is the most sensitive parameter for our case.
\end{abstract}




\section{INTRODUCTION}

The application of immobilized, growing cell systems has become of increasing interest in the past few years. Examples of applications are immobilized yeast cells for ethanol production, ${ }^{10,24,33}$ and producing acrylamide from acrylonitril with Corynebacterium ${ }^{8}$. Traditionally, biofilms are used in wastewater treatment, ${ }^{3,28,36,38}$ and in this field the use of entrapped nitrifying bacteria is gaining importance. ${ }^{42}$

Many researchers have reported the phenomenon of growth of cells near the surface of immobilized particles, whereas in the centre of these particles no growth, or even decay of cells occurred. ${ }^{18,18,30,40.42}$ As a result of this non-homogeneous growth, the characteristics of the solid phase will alter, thereby affecting, among other things, the effective diffusion coefficient. ${ }^{5}$

The main feature of immobilized growing systems is the high attainable concentration of active biocatalyst in the solid phase, which, combined with a high reactor load, can lead to small reactor volumes compared to cell suspensions. A major drawback of these systems can be considered to be the rather troublesome mathematics involved with the simultaneous diffusion of substrate and/or product(s) and the growth of the immobilized cells. Steady-state models for growing cells $\mathbf{s}^{1,19,38}$ can be quite satisfactory for design purposes but may fail to describe the start-up phase and the response to changing conditions in the reactor system. In recent work, Nakasaki et al. ${ }^{24}$ and Sayles and Ollis ${ }^{3 t}$ presented a dynamic model describing the transient growth of immobilized cells. However, in both studies external mass transfer resistance was neglected, whereas Nakasaki et al. also did not consider a biomassdependent effective diffusion coefficient. Only recently, Monbouquette et al. ${ }^{21}$ presented a model that included both external mass transfer and a biomass-dependent diffusion coefficient.

In this article we describe the modelling of the growth of immobilized cells, accounting for external mass transfer resistance and simultaneous diffusion and consumption of substrate for respiration and growth, using a biomass concentrationdependent diffusion coefficient. The growth model used allows a negative net growth, and the biomass concentration is limited to a maximum value. The model has been tested by experiments in continuously operated air-lift loop reactors with Nitrobacter agilis cells immobilized in $\kappa$-carrageenan. 


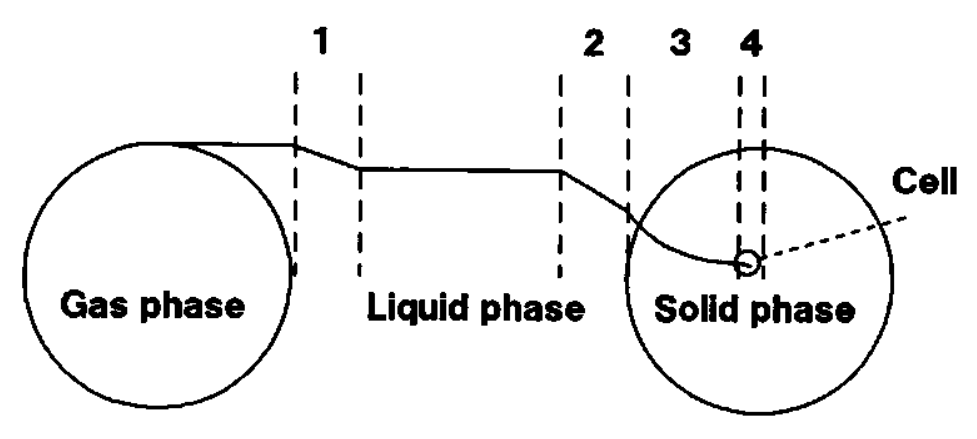

Fig. 1: Oxygen transfer in an air-lift loop reactor with immobilized cells.

\section{THEORY}

\section{General consideration}

In many aerobic systems oxygen is the limiting substrate, due to the rather low solubility. For our case, oxygen transfer can be divided into four different regions, as illustrated in Fig. 1. Oxygen has to be transferred (1) from the (ideally mixed, with a negligible stagnant gas layer) gas phase through a stagnant liquid layer to the (ideally mixed) bulk phase, (2) from the bulk phase through a stagnant layer adjacent to the solid phase, (3), in the solid phase to the cells, and (4) into the cells to the enzyme complex. In order to define the rate-limiting steps, we calculated the characteristic times for each step, as presented in Table I. Also, the possibility of exhaustion of oxygen from the gas bubble has to be considered. As for our case, the residence time of the air bubbles (1.2 s) is much lower than the characteristic time for exhaustion (33 s; Appendix) oxygen depletion is quite unlikely. With scale-up, however, the air bubble exhaustion might become considerable. ${ }^{25}$ 


\begin{tabular}{|c|c|c|c|}
\hline Step & $\begin{array}{l}\text { Time constant } \\
\text { (s) }\end{array}$ & Calculated from & Reference \\
\hline 1 & 166 & $T=\frac{1}{k_{h, g}}$ & 4, 22; see also Appendix \\
\hline 2 & 31 & $T=\frac{1}{k_{l, s^{a}}}$ & 22, 29; see also Appendix \\
\hline 3 & 66 & $\frac{D_{b} T}{r_{b}^{2}}=0.1$ & 9 \\
\hline 4 & $10^{-4}$ & $\frac{D_{e} T}{r_{c}^{2}}=0.1$ & 9 \\
\hline
\end{tabular}

The diffusion of oxygen into the cells is fast in comparison to diffusion through the stagnant layers and in the solid phase. In our experimental set-up, the bulk concentration of substrate was kept constant. Therefore, in this study we do not consider mass transfer from the gas phase, and neglect diffusion within the cells. From Table I, it might be concluded that diffusion through the film layer can be neglected also, and the only limiting step would be diffusion within the solid phase. However, since the cells will grow in the outer shells of the bead, a biofilm develops, and the distance over which substrate is transported is smaller than the radius of the bead. Hence, the value for the radius used in Table I should be decreased. If a radius of 100 $\mu \mathrm{m}$, being a typical film thickness, is substituted, we find a characteristic time of 0.6 $\mathrm{s}$. This indicates that, for our case, external diffusion limitation should be considered.

\section{Growth model}

Apart from the logistic growth model, ${ }^{23}$ the model of Herbert ${ }^{13}$ or Pirt ${ }^{26}$ is often used to describe growth of cells. Both models, however, have some major drawbacks, as stated by Beeftink et al.: the Herbert model (i) features a maximum specific growth rate 
that cannot be measured directly and (ii) directs that cells cover their maintenance requirements from biomass, even in the presence of excess substrate, whereas the Pirt model shows (i) a growth rate that is always positive or zero, and (ii) a non-zero substrate consumption even if no substrate is available.

In the case of growing immobilized cells, substrate depletion near the centre of the biocatalyst bead may occur, whereas a high substrate concentration will be available near the surface. Hence, a growth model is needed that is capable of describing both situations, allowing a negative net growth at low substrate concentrations and an observable maximum growth rate at high substrate concentrations. As Pirt's extended mode $\left.\right|^{27}$ would introduce an extra variable, we use the growth model suggested by Beettink et al. ${ }^{2}$ :

$$
\begin{aligned}
& r_{s}=\frac{\mu}{Y_{x s}} X+m X\left(\frac{S}{K_{s}+S}\right) \\
& r_{x}=\mu X-m Y_{x s} X\left(1-\frac{S}{K_{s}+S}\right)
\end{aligned}
$$

This is a combination of the models of Pirt and Herbert. At low substrate concentrations, this model will perform as the Herbert model, while at high substrate concentrations it acts as the Pirt model.

The model is based on the consumption of one limiting substrate only. For our case, nitrification, both nitrite and oxygen are substrates. Andrews' showed that the component with the lowest product of diffusion coefficient, yield factor and concentration in the liquid phase is rate limiting. For our case, oxygen is always rate limiting. ${ }^{43}$

\section{Diffusion coefficient}

As stated before, many researchers proved that the effective diffusion coefficient is affected by the concentration of biomass in the support material. The theoretically most correct way of describing this phenomenon by considering the tortuosity and the porosity of the gel matrix will introduce two, hardly determinable, variables. Therefore, 
more convenient relations were proposed by Scott et al. and Wakao and Smith ${ }^{41}$. These relations use the specific cell volume. Recent work of Stewart, Karel and Robertson suggests that cells can grow under considerable pressure, thereby decreasing their specific cell volume. ${ }^{16.37}$ As in the support matrix the available space for growth will be limited, the specific cell volume may be altered, and therefore its accurate determination is troublesome.

The determination of the effective diffusion coefficient at high biomass concentrations is also difficult: a homogeneous high biomass concentration can hardly be reached, and for a correct determination the cells must be intact, and therefore a non-consumable compound with the same physical properties as the substrate must be found, which is difficult. Alternatively, using oxygen as diffusing compound, the respiration of the cells must be stopped, and then the properties of the cells, and with that the effective diffusion coefficient, may be altered. Even if a suitable compound can be found, the relative error in the determination of the diffusion coefficient in biocatalyst beads is considerable. ${ }^{15}$

In order to account for the dependency of the effective diffusion coefficient on the biomass concentration, we have implemented a relationship that generates an effective diffusion coefficient that varies linearly with the biomass concentration between the diffusion coefficient in the gel and zero. The effective diffusion coefficient will become zero when all available space in the gel matrix is occupied by biomass, and if no biomass is present, the effective diffusion coefficient becomes equal to the diffusion coefficient in the gel. Mathematically this leads to:

$$
D_{e}-D_{e, g}\left(1-\frac{X}{X_{p, \max }}\right)
$$

\section{Calculations}

In order to facilitate a numerical solution, we treat the biomass growth and substrate consumption process separately. This is a valid approach as long as the time scale for growth is larger then the time scale for consumption. ${ }^{12,16}$ For our case, the characteristic time for growth is $10^{5} \mathrm{~s}$ (calculated from $1 / \mu_{\text {max }}$ ), and for substrate 
consumption $66 \mathrm{~s}$ (from Table l; characteristic time for diffusion). Hence, if i) time is discretisized, ii) a pseudo-steady-state substrate distribution inside the support matrix is assumed within one time step, and iii) the effective diffusion coefficient is assumed to be constant within one time step and within one step in the integrating algorithm, a differential mass balance over a biocatalyst bead in which simultaneous diffusion and consumption of substrate takes place combined with Equation (1) leads to

$$
\frac{d^{2} S}{d r^{2}}-\frac{\frac{\mu}{Y_{x s}} X(t)+m X(t)\left(\frac{S}{K_{s}+S}\right)}{D_{\theta}}-\frac{2}{r} \frac{d S}{d r}
$$

Boundary conditions for Equation (4) are:

$$
\begin{aligned}
& s=S_{s} \quad \text { at } \quad r=r_{b} \\
& \frac{d S}{d r}=0 \quad \text { at } \quad r=0 \text { or } r=r_{f}
\end{aligned}
$$

We have solved Equation (4) numerically using a second-order Runge-Kutta algorithm with Newton's method to satisfy the boundary conditions. Starting with a small value for $r_{f}$ and $S_{f}$ this results in a substrate concentration profile in the bead and a computed substrate concentration $S_{s}$ and a $d S / d r$ at $r=r_{b}$.

In order to account for external mass transfer resistance, the latter can (optionally) be used for calculating a $S_{s}^{\prime}$ by means of the equation representing the film theory:

$$
S_{s}^{\prime}=S_{b}-\left.\frac{D_{\theta}}{k_{l s}} \frac{d S}{d r}\right|_{r-r_{b}}
$$

While varying either $r_{f}$ or $S_{f}$, Equations (4) and (5) are solved iteratively until the $S_{s}$ and $S_{s}$, match, after which the new biomass distribution is calculated according to Equation (2). The calculation scheme, including the procedure used if the substrate concentration becomes essentially zero before the centre of the support matrix is reached, as presented earlier ${ }^{7}$ is illustrated in Fig. 2. 


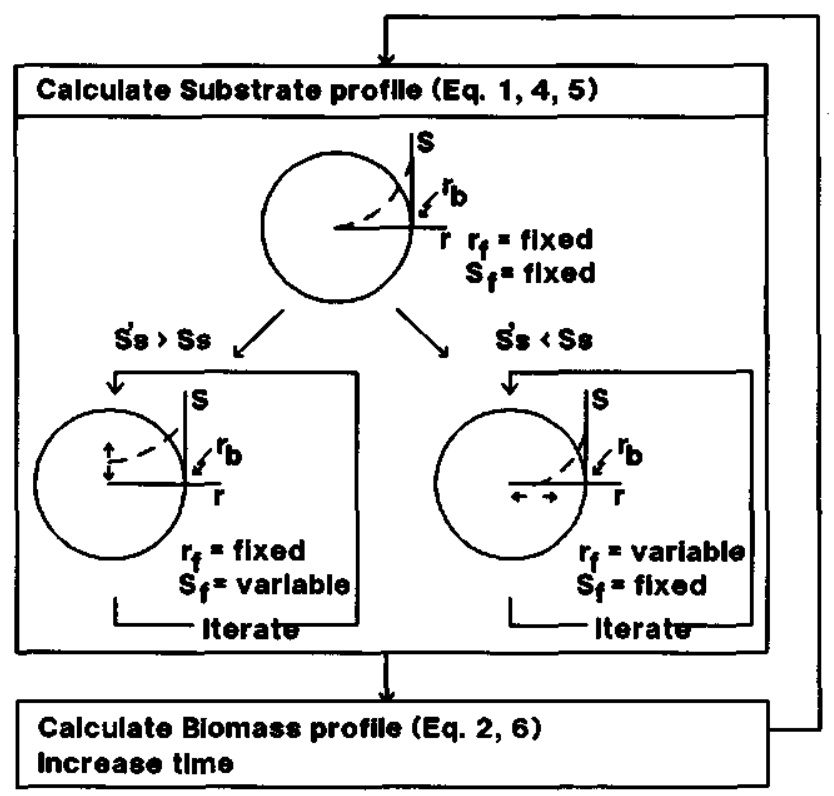

Fig. 2: Calculation of substrate and biomass concentration profiles in a biocatalyst bead.

The software program incorporating the model presented here is written in Pascal on an HP vectra QS with 80387 mathematical coprocessor. An average run from time 0 to $1000 \mathrm{~h}$ requires about 4 minutes CPU time, which is more than thousand times faster than the program presented by Monbouquette et al. ${ }^{21}$ This is probably caused by our much larger time steps, and the fact that we do not calculate biomass fluxes.

\section{Maximum biomass concentration}

A straightforward application of Equation (1) would lead to infinitively high biomass concentrations near the surface of the bead. As this is impossible, a restriction is added to this equation:

$$
X \leq X_{\max }
$$

where $X_{\max }$ is the observable maximum biomass concentration inside the support 
matrix (which is not the same as $X_{p, \text { max }}$ ). This is, in a different notation, the same restriction as used by Toda and Sato ${ }^{40}$ and the same as used by Sayles and Ollis ${ }^{31}$ and Monbouquette et al. ${ }^{21}$ Nakasaki et al. ${ }^{24}$ did not explicitly consider this in their mathematical description, but mention the use of $X_{\max }$ in their text. As the substrate consumption does not decrease when $X$ has reached the value of $X_{\text {max }}$ according to Equation (1), the substrate uptake by the cells may be used for a waste metabolism as suggested by McLaren ${ }^{17}$ or the cells may continue to grow and leak out of the support matrix as described by Sayles and Ollis, ${ }^{31}$ Monbouquette et al., ${ }^{21}$ Monbouquette and Ollis, ${ }^{20}$ and Cheng and Huang. ${ }^{5}$ In the latter case, Shiraishi et $a . .^{35}$ stated that the substrate consumption of free cells may be neglected if the dilution rate in the reactor is much larger than the dilution rate at washout conditions, as in our case. This has been experimentally confirmed. ${ }^{43}$

\section{RESULTS AND DISCUSSION}

\section{General Model}

A typical result of the model is shown in Fig. 3. In the transient growth of immobilized cells, 4 phases can be recognized. in phase 1 , there is hardly any diffusion limitation, and homogeneous growth occurs. Phase 2 shows inhomogeneous growth, as in the centre of the sphere substrate depletion aggravates. In phase 3, the substrate hardly reaches the core of the sphere, so biomass decays, whereas at the outer shell the biomass concentration reaches its maximum. In phase 4 this process of growth and decay continues and a distinct biomass film develops, whereas the substrate concentration in the centre of the sphere increases. At the end time of the simulation a distinct biomass film near the surface of the bead has developed, whereas the substrate concentration inside the bead corresponds to maintenance level of zero net growth, which is the same result as reported by Sayles and Ollis. ${ }^{31}$ By substituting $r(x)=0$ in Equation (2), this value can be calculated from:

$$
s-\frac{m Y_{x s} K_{s}}{\mu_{\max }}
$$



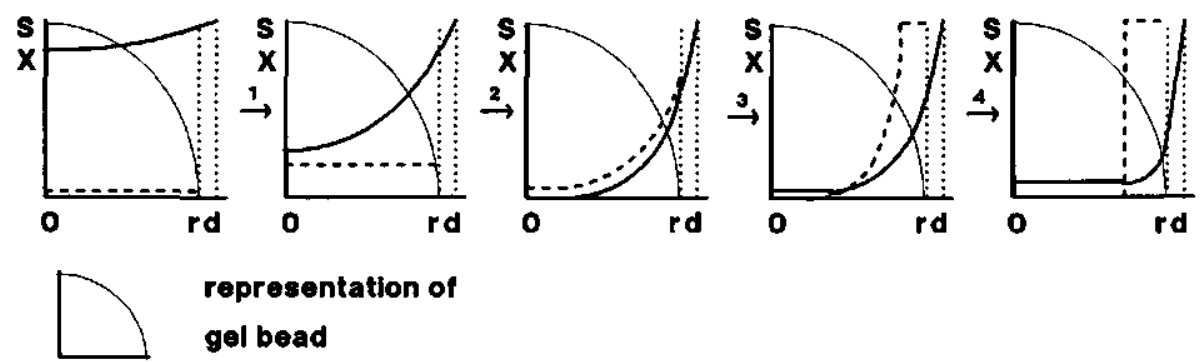

representation of

gel bead

Fig. 3: Typical model predictions for growth of immobilized cells. Substrate $(-)$ and biomass concentrations (-) vs. radial position $r$ at various times. The external layer is represented by $d$.

Fig. 3 clearly shows the increasing importance of external diffusion limitation in time. At the end time of the simulation, the concentration of substrate at the surface of the bead is only half the bulk concentration.

\section{Model evaluation}

The model was verified with Nitrobacter agilis cells immobilized in $\kappa$-carrageenan, as presented by Wijfels et al..$^{43}$ Immobilized cells were kept in an air-lift loop reactor at sufficiently high nitrite concentrations and constant oxygen concentrations, Table II: Parameters used in the model evaluation

\begin{tabular}{|c|c|c|}
\hline Parameter & Value & Unity \\
\hline$k_{l, s}$ & $3.7 \times 10^{-5}$ & $\mathrm{~m} \cdot \mathrm{s}^{-1}$ \\
\hline D. & $1.58 \times 10^{-8}$ & $m^{2} \cdot s^{-1}$ \\
\hline$r_{b}$ & $1.02 \times 10^{-3}$ & $\mathrm{~m}$ \\
\hline$x_{0}$ & $4.5 \times 10^{-3}$ & $\mathrm{~kg} \cdot \mathrm{m}^{-3}$ \\
\hline$x_{p, \text { max }}$ & 950 & $\mathrm{~kg} \cdot \mathrm{m}^{-3}$ \\
\hline$t_{\text {end }}$ & 42 & day \\
\hline$\Delta t$ & 1 & day \\
\hline$Y_{x s}$ & $1.16 \times 10^{-3}$ & kg. $\mathrm{mol}^{-1}$ \\
\hline$\mu_{\max }$ & $1.0 \times 10^{-5}$ & $\mathbf{s}^{-1}$ \\
\hline$K_{s}$ & $1.7 \times 10^{-2}$ & mol. $\mathrm{m}^{-3}$ \\
\hline$m$ & $1.1 \times 10^{-3}$ & mol. $\mathrm{kg}^{-1} \cdot \mathrm{s}^{-1}$ \\
\hline$X_{\text {mex }}$ & 11 & $\mathrm{~kg} \cdot \mathrm{m}^{-3}$ \\
\hline$S_{b}$ & $0.012 / 0.038 / 0.08$ & mol. $\mathrm{m}^{-3}$ \\
\hline
\end{tabular}
so that oxygen was the limiting substrate. At three different oxygen concentrations the macroscopic oxygen 


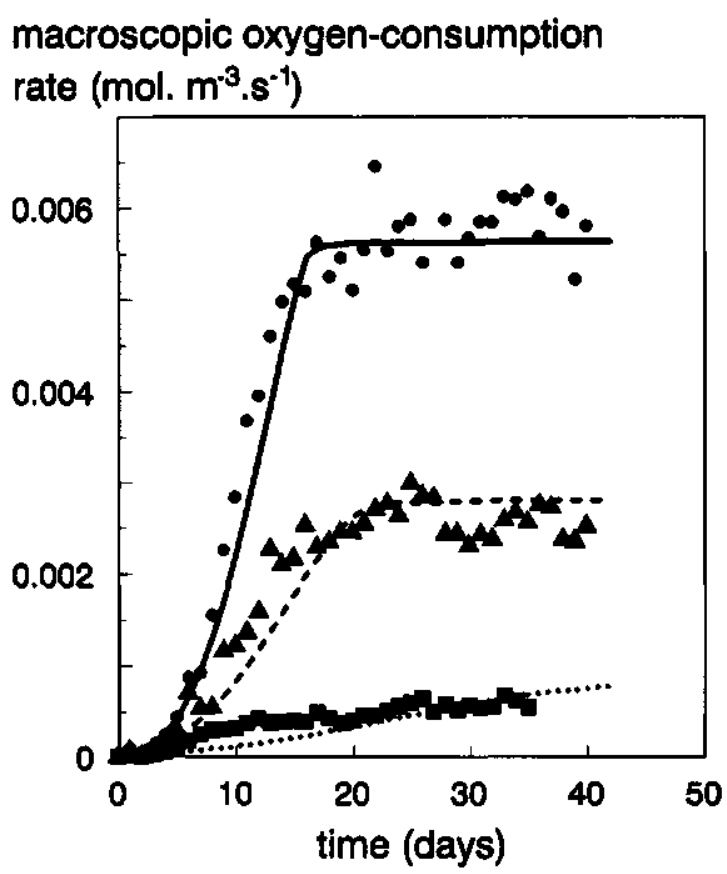

Fig. 4: Experimental evaluation of the model. ${ }^{43}$ Macroscopic consumption rates at three different oxygen concentrations vs. time. Lines are model predictions, markers are experimental data. Experiments were performed at oxygen concentrations of $0.012 \mathrm{~mol}^{-3} \mathrm{~m}^{-3}(\omega, \ldots),. 0.038 \mathrm{~mol}^{-3} \mathrm{~m}^{-3}(4$, $-)$ and $0.08 \mathrm{~mol} . \mathrm{m}^{-3}(0,-)$.

consumption rates were determined in time by measuring the nitrite consumption rate, and compared to model predictions. Parameters used in the model are given in Table II, and results are shown in Fig. 4. As shown in Fig. 4, the curves predicted by the model presented here match the experimental results very well.

\section{Sensitivity analysis}

To establish the sensitivity of the model for the different parameters, a sensitivity analysis was made around the set point values used in the evaluation (Table II). Each parameter was varied in the range 0.5-1.5 times the setpoint value, keeping all other 

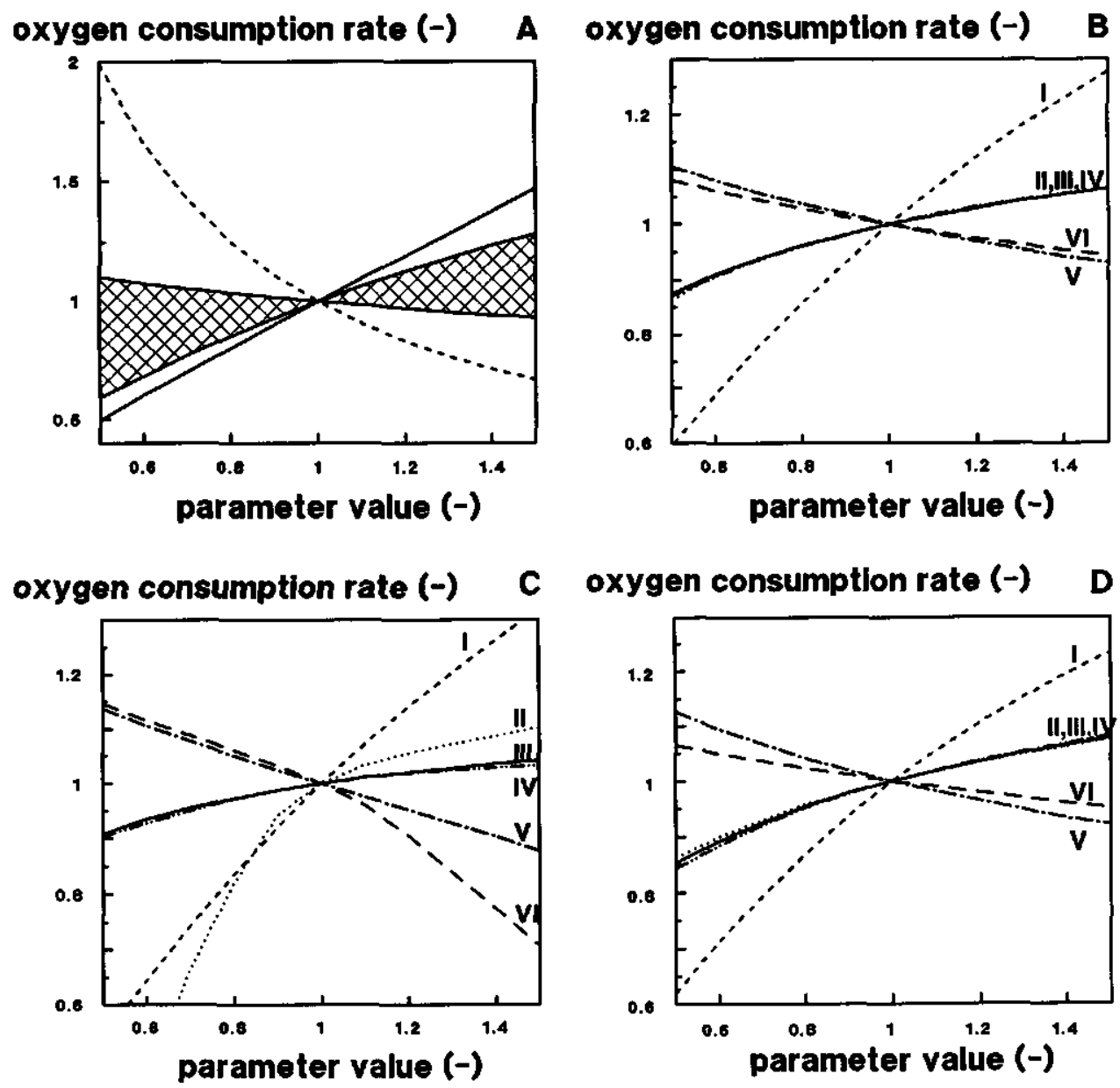

Fig. 5: Sensitivity analysis of the model. Oxygen bulk concentration is $3.8 \times 10^{-2} \mathrm{~mol} \mathrm{~m}^{.3} \mathrm{ln}$ (A) and (B) and $1.2 \times 10^{-2}$ and $8.0 \times 10^{-2} \mathrm{~mol}^{-3} \mathrm{~m}^{-3}$ in (C) and (D), respectively. (A-D) Oxygen flux is plotted vs. the dimensionless parameter value. In (A) solid line is the bulk concentration, dashed line is the radius, and the shaded area represents all other parameters (B-D). I, mass transfer coefficient in the film; II, maximum specific growth rate; III, diffusion coefficlent; IV, maximum biomass concentration in the gel; V, yield coefficient; VI, Monod constant. 
variables constant. The predicted macroscopic consumption rate $\left(\mathrm{mol} . \mathrm{m}_{\text {bead }}^{-3} \mathrm{~s}^{-1}\right)$ at steady state was used to compare the predictions, realizing that other criteria can be used. Results are presented in Fig. 5. Fig. 5A clearly shows the high sensitivity of the model for the radius of the beads and the substrate bulk concentration. At other oxygen bulk concentrations the same model behaviour was found (results not shown). The model showed no response at changing the time step size over the same range, which indicates that the assumption that the substrate consumption process and growth may be treated separately, was valid. Varying the maximum attainable biomass concentration $X_{p, \max }$, which only appears in Equation (3), did not result in a change in predicted substrate consumption rate, which can, for our case, be explained by the relatively low maximum biomass concentration $X_{\text {max }}$.

At all oxygen bulk concentrations, the model showed no response to a change in initial biomass concentration, indicating that at these set points, the model is capable of finding the steady state rather well. Varying the end time of the simulation showed no response for the high bulk concentrations, whereas at the low oxygen concentration setpoint a $50 \%$ smaller flux was predicted at the lowest end time, and from the set point to a higher end time no change occurred, indicating that at low bulk concentrations, it takes longer to reach the steady state, probably due to the low growth rate. Varying the maintenance coefficient at high bulk concentrations influenced the substrate flux less than $1 \%$, whereas at a low bulk concentration the predicted flux decreased by $10 \%$ at a $50 \%$ higher maintenance coefficient. This is a result of the use of Equation (1), where the second term will become more important compared with the first term at concentrations in the same magnitude as $K_{s}$, i.e., at the low oxygen bulk concentration.

The similarity between Figs. 5B and 5D indicates that at higher substrate bulk concentrations, the entire process becomes diffusion controlled, whereas at low substrate bulk (Fig. $5 \mathrm{C}$ ) concentrations the kinetics gain importance. From Fig. 5 it is clear that apart from the radius and the bulk concentration, the most important parameter is the mass transfer coefficient in the stagnant layer, which indicates the importance of external mass transfer resistance.

The model was also tested without external diffusion limitation. Steady-state oxygen consumption rates are given in Table III where it is clearly shown that for our case, external mass transfer resistance is not negligible. 
Table III: Oxygen consumption rates with and without external diffusion limitation

\begin{tabular}{|c|c|c|c|}
\hline Oxygen bulk concentration (mol. $\mathrm{m}^{-3}$ ) & $1.2 \times 10^{-2}$ & $3.8 \times 10^{-2}$ & $8.0 \times 10^{-2}$ \\
\hline $\begin{array}{l}\text { Oxygen consumption rate with film } \\
\left.\text { theory (mol. } \mathrm{m}^{-3} \cdot \mathrm{s}^{-1}\right)\end{array}$ & $8.1 \times 10^{-4}$ & $2.8 \times 10^{-3}$ & $5.6 \times 10^{-3}$ \\
\hline $\begin{array}{l}\text { Oxygen consumption rate without film } \\
\left.\text { theory (mol. } \mathrm{m}^{-3} \cdot \mathrm{s}^{-1}\right)\end{array}$ & $2.7 \times 10^{-3}$ & $7.0 \times 10^{-3}$ & $1.2 \times 10^{-2}$ \\
\hline Ratio (dimensionless) & 3.3 & 2.5 & 2.1 \\
\hline
\end{tabular}

\section{CONCLUSIONS}

The modelling of immobilized Nitrobacter agilis cells was successfully carried out. Measured macroscopic oxygen consumption rates matched well with model predictions at three different oxygen concentrations. The model shows, at the values of the parameters used in this case, the highest sensitivity for the substrate bulk concentration, the radius of the biocatalyst beads, and the external mass transfer resistance coefficient. More research is under way to verify the model prediction of the substrate concentration profile as proposed by de Beer et al. ${ }^{6}$ and to extend the model to an overall reactor model.

\section{APPENDIX: CALCULATION OF THE CHARACTERISTIC TIMES FOR AIR BUBBLE EXHAUSTION AND OXYGEN TRANSFER}

As from our experiments the oxygen consumption rates are known at three different oxygen bulk concentrations, $k a$ values for mass transfer from the gas bubbles can be calculated, since in steady state, the oxygen consumption rate must equal oxygen transfer:

$$
r_{s}-k_{l, g} a_{g}\left(s_{b}^{*}-s_{b}\right)
$$

with: 


$$
a_{g}-\frac{6}{d_{b}}
$$

Table IV: Characteristic times for oxygen transfer and exhaustion at three different bulk concentrations

\begin{tabular}{lllll}
\hline$S_{b}$ & $1.2 \times 10^{-2}$ & $3.8 \times 10^{-2}$ & $8.0 \times 10^{-2}$ & $\mathrm{~mol} . \mathrm{m}^{-3}$ \\
$r_{s}$ & $1.3 \times 10^{-4}$ & $4.4 \times 10^{-4}$ & $8.8 \times 10^{-4}$ & $\mathrm{~mol} . \mathrm{m}^{-3} . \mathrm{s}^{-1}$ \\
$S_{b}^{*}$ & $1.3 \times 10^{-2}$ & $1.2 \times 10^{-1}$ & $2.1 \times 10^{-1}$ & $\mathrm{~mol} . \mathrm{m}^{.3}$ \\
$T_{\text {extresston }}$ & 1.5 & 37 & 30 & $\mathrm{~s}$ \\
$T_{\text {tenseler }}$ & 7.6 & 181 & 151 & $\mathrm{~s}$ \\
\hline
\end{tabular}

The characteristic time for exhaustion of the gas bubble can be calculated from 25,39

$$
T_{\text {exheustion }}=\frac{H}{k_{l, g} a_{g}}
$$

The characteristic time for oxygen transfer from the gas bubbles to the liquid phase can be calculated from ${ }^{25,39}$

$$
T_{\text {transter }}-\frac{1}{k_{l g} a_{l}}
$$

with:

$$
a_{l}-a_{g} \frac{\epsilon}{1-\epsilon}
$$

Characteristic times calculated from our experiments, using $H=40 \mathrm{~m}^{3} . \mathrm{m}^{-3}, \epsilon=0.5$ $\%$, and $d_{b}=0.5 \mathrm{~mm}$ are given in Table IV.

The considerable difference in the characteristic times at the low oxygen concentration are probably caused by oxygen transfer through the head space of the reactor. This contribution will become negligible at higher oxygen bulk concentrations and, with that, higher consumption rates are reached in the steady state. Therefore, 
the calculated characteristic times at the low bulk concentration will not be considered.

As can be seen from Table IV, the characteristic time for exhaustion of the gas bubbles can be estimated to be $33 \mathrm{~s}$, and for oxygen transfer this is $166 \mathrm{~s}$. These values lie well within the range of values that can be found using correlations for $k_{t}$ reported in literature. ${ }^{34}$

\section{NOMENCLATURE}

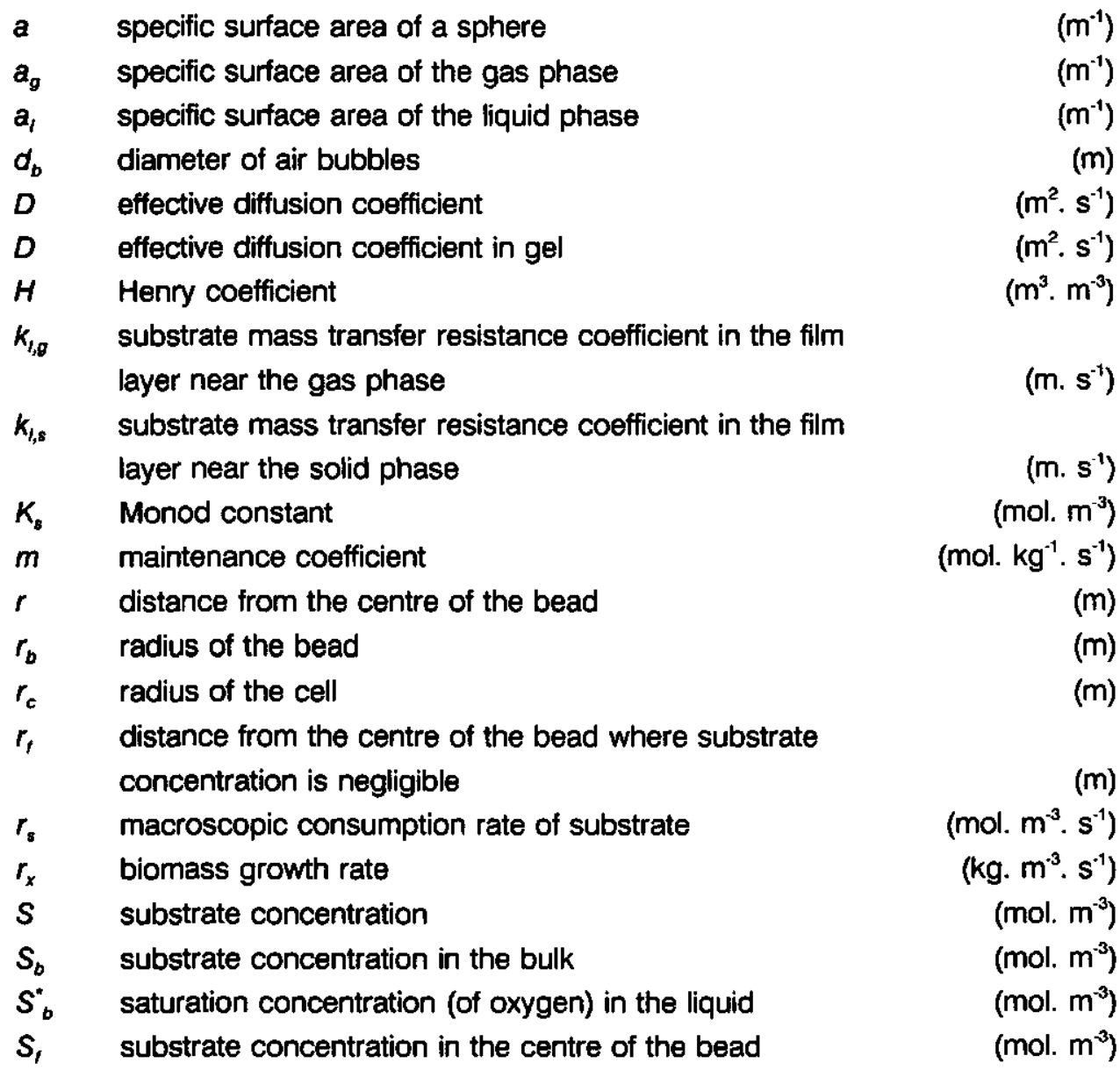


$S_{s} \quad$ substrate concentration at the surface of the bead

(mol. $\left.\mathrm{m}^{-3}\right)$

$S_{s}^{\prime} \quad$ substrate concentration at the surface of the bead, when

external diffusion limitation is accounted for

(mol. $\left.\mathrm{m}^{-3}\right)$

t time

$t_{\text {end }}$ end time of the simulation

$x$ biomass concentration

(kg. $\left.\mathrm{m}^{-3}\right)$

$x_{0} \quad$ biomass concentration at $\mathrm{t}=0$

(kg. $\left.\mathrm{m}^{-3}\right)$

$X_{\max }$ observable maximum biomass concentration

(kg. $\mathrm{m}^{-3}$ )

$X_{p, \max }$ maximum attainable biomass concentration

(kg. $\left.\mathrm{m}^{-3}\right)$

$Y_{x s} \quad$ yield coefficient

(kg. $\left.\mathrm{mol}^{-1}\right)$

$\epsilon \quad$ gas hold-up

$\mu \quad$ specific growth rate

$\mu_{\max } \quad$ maximum specific growth rate

$T \quad$ characteristic time

$\Delta t \quad$ time step size for biomass growth (Equation 2)

\section{ACKNOWLEDGEMENTS}

The authors wish to thank Dr. M. de Gee for his useful comments on the numerical solution of the differential equations, and W.A. Beverloo for the fruitful discussions on ka.

\section{REFERENCES}

1. Andrews G (1988) Effectiveness factors for bioparticles with Monod kinetics. Chem Eng J 37:b31-b37

2. Beeftink H.H., Van Der Heijden R.T.J.M., Heijnen J.J. (1990) Malntenance requirements: energy supply from simultaneous endogenous respiration and substrate consumption. FEMS Microbiol Ecol 73: 203-210

3. Canovas-Diaz M., Howell J.A. (1988) Stratified mixed-cuture biofilm model for anaeroblc digestion. Biotechnol Bloeng 32: 348-355

4. Chang H.N., Moo-Young M. (1988) Analysis of oxygen transport in immobilized whole cells. In: 
Bioreactor Immobilized Enzymes \& Cells, fundamentals and applications, Ed. M. Moo-Young, Elsevier Applied Science, London

5. Chen K.C., Huang C.T. (1988) Effects of the growth of Trichosporon cutaneum in Ca-alginate gel beads upon bead structure and oxygen transfer characteristics. Enzyme Microb Technol 10: 284-292

6. De Beer D., Van Den Heuvel J.C. (1988) Gradients in immobilized biological systems. Anal Chim Acta 213: 259-265

7. De Gooljer C.D., Hens H.J.H., Tramper J. (1989) Optimum design for a series of CSTR's containing immobilized biocatalyst obeying intrinsic Michaelis-Menten kinetics. Bioprocess Eng 4: $153-158$

8. Furusaki S. (1988) Engineering aspects of immobilized biocatalysts. J Chem Eng of Japan 21 (3): 219-230

9. Furusakl S. (1989) Intradiffusion effect on reactivity of immobilized microorganisms. In: Bioproducts \& Bioprocesses, Eds: Fiechter, Okada, Tanner, Springer-Verlag, Berlin 71-85

10. Godia F., Casa C., Sola C. (1987) Mathematical modelization of a packed bed reactor performance with immobilized yeast for ethanol fermentation. Biotechnol Bioeng 30: 836-843

11. Gosmann B., Rehm H.J. (1988) Influence of growth behaviour and physiology of alginate-entrapped microorganisms on the oxygen consumption. Appl Microb Biotechnol 29: 554-559

12. Gujer W., Boller M. (1989) A mathematical model for rotating blological contactors. In: Proceedings of the Technical Advances In Biofilm Reactors Conference, Nice, CFRP-AGHTM, Paris, p. 69-89

13. Herbert D. (1959) Some principles of continuous culture. In: Recent progress in microbiology, Ed. Tunevall G, Almqvist \& Wiksell, Stockholm, p. 381-396

14. Hiemstra H., Dijkhuizen L., Harder W. (1983) Diffusion of oxygen in alginate gels related to the kinetics of methanol oxidation by immobilized Hansenula polymorpha cells. Appl Microb Biotechnol 18: 189-196

15. Itamunoala G.F. (1988) Limitations of methods of determining effective diffusion coefficients in cell immobilization matrices. Biotechnol Bioeng 31: 714-717

16. Karel S.F., Robertson C.R. (1989) Cell mass synthesis and degradation by immobilized Escherichia coli. Biotechnol Bioeng 34: 337-356

17. McLaren A.D. (1970) Temporal and vectorial reactions of nitrogen in soil: a review. Can J Soil Sc 50: 97-109

18. Mahmoud W., Rehm H.J. (1986) Morphological examination of immobilized Streptomyces aureofaciens during chlortetracycline fermentation. Appl Microb Biotechnol 23: 305-310

19. Monbouquette H.G., Olis D.F. (1986) A structured model for immobilized cell kinetics. Ann NY Acad Sc 469: 230-244

20. Monbouquette H.G., Ollis D.F. (1988) Structured modeling of immobilized cell kinetics and RNA content. In: Bioreactor Immobilized Enzymes \& Cells, fundarnentals and applications, Ed. M. 
Moo-Young, Elsevier Applied Science, London

21. Monbouquette H.G., Sayles G.D., Ollis D.F. (1990) Immobilized cell biocatalyst activation and pseudo-steady-state behavior: model and experiment. Blotechnol. Biceng. 35: 609-629

22. Moser A. (1988) Bioprocess Technology: kinetics and reactors. Springer-Verlag, New York, USA

23. Mulchandanl A., Luong J.H.T., Leduy A. (1988) Batch kinetics of microbial polysaccharide biosynthesis. Biotechnd Bioeng 32: 639-646

24. Nakasaki K., Murai T., Aklyama T. (1989) Dynamic modeling of immobilized cell reactor: application to ethanol fermentation. Biotechnol Bioeng 33: 1317-1323

25. Oosterhuis N.M.G. (1984) Scale-up of bioreactors: a scale-down approach. PhD. thesis, Technical University, Delft, the Netherlands

26. Pirt S.J. (1965) The maintenance energy of bacteria in growing cultures. Proc Roy Soc London. 1638: 224-231

27. Pirt S.J. (1987) The energetics of microbes at slow growth rates: maintenance energies and dormant organisms. J Ferment Technol 65 (2): 173-177

28. Saez P.B., Rittmann B.E. (1988) Improved pseudoanalytical solution for steady state blofilm kinetics. Biotechnol Biceng 32: 379-385

29. Sänger P., Deckwer W.D. (1981) Liquid-solid mass transfer in aerated suspensions. Chem Eng J 22: 179-186

30. Sato K., Toda K. (1983) Oxygen uptake rate of immobilized growing Candida lipolytica. J Ferment Technol 6 (3): 239-245

31. Sayles G.D., Ollis D.F. (1989) Periodic operation of immobilized cell systems: analysis. Biotechnol Bioeng 34: 160-170

32. Scott C.D., Woodward C.A., Thompson J.E. (1989) Solute diffusion in biocatalyst gel beads containing biocatalysis and other additives. Enzyme Microb Technol 11: 258-263

33. Seki M., Furukasi S. (1985) Effect of intraparticle diffusion on reaction by immobilized growing yeast. J Chem Eng of Japan 18 (5): 461-463

34. Shah. Y.T., Kelkar B.G., Godbole S.P., Deckwer W.D. (1982) Design parameters estimations for bubble column reactors. AlChE J 28: 353-379

35. Shiraishi F., Kawakami K., Kono S., Tamura A., Tsurata S., Kusunoki K. (1989) Characterization of production of free gluconic acid by Gluconobacter suboxydans adsorbed on ceramic honeycomb monolith. Biotechnol Bioeng 33: 1413-1418

36. Siegrist H., Gujer W. (1987) Demonstration of mass transfer and pH effects in a nitrifying biofilm. Wat Res 21 (12): 148t-1487

37. Stewart P.S., Robertson C.R. (1989) Microbial growth in a fixed volume: studies with entrapped E. coli. Appl Microb Biotechnol 30: 34-40

38. Suidan M.T., Rittman B.E., Traegner U.K. (1987) Criteria establishing biofilm-kinetic types. Wat Res 21 (4): 491-498

39. Sweere A.P.J., Luyben K.Ch.A.M., Kossen N.W.F. (1987) Regime analysis and scale down: tools 


\section{Chapter 3}

to investigate the performance of bioreactors. Enzyme Microbiol Technol 9: 386-398

40. Toda K., Sato K. (1985) Simulation study on oxygen uptake rate of immobilized growing microorganisms. J Ferment Technol 63 (3): 251-258

41. Wakao N., Smith J.M. (1962) Diffusion in catalyst pellets. Chem Eng Sci 17: 825-834

42. Wijfiels R.H., Tramper J. (1989) Performance of growing Nitrosomonas europaea cells immobillzed in $\kappa$-carrageenan. Appl Microbiol Biotechnol 32: 6 108-112

43. Wiffels R.H., De Gooijer C.D., Kortekaes S., Tramper J. (1991) Growth and substrate consumption of Nitrobacter agilis cells immobilized in carrageenan: part 2. model evaluation. Blotechnol. Bloeng. 38: 232-240 
INTERMEZZO 


\section{INTERMEZZO}

The beads with immobilized Nitrosomonas or Nitrobacter cells are brought in a reaction vessel. A medium containing ammonia (the waste stream) is supplied continuously to that bioreactor and the ammonia will be converted to nitrite or nitrate by the immobilized bacteria. As a consequence the effluent (cleaned waste stream) contains nitrite or nitrate. In case suspended bacteria are used, the bacteria would leave the reactor together with the effluent. By immobilizing cells in gel beads we can retain the bacteria in the bioreactor by simply putting a sieve in the effluent stream.

As a bioreactor we use an air-lift loop reactor. It consists out of two connected vertical tubes. Air is sparged into the left tube. Air is needed for both the oxidation of ammonia or nitrite and for mixing. 


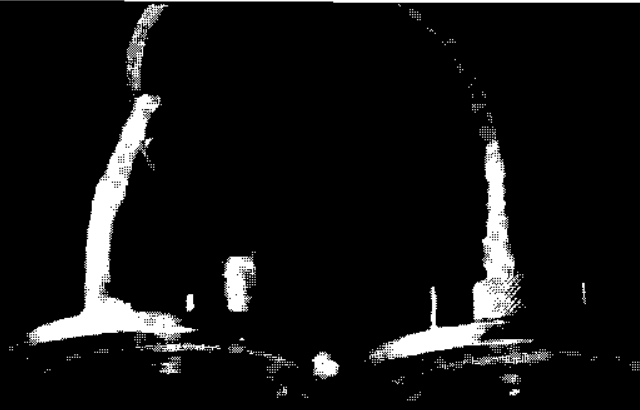


This chapter has been published in Biotechnology and Bioengineering 38 (1991) 232-240 by the authors R.H. Wijffels, C.D. de Gooijer, S, Kortekaas and J. Tramper

\section{CHAPTER 4}

\section{GROWTH AND SUBSTRATE CONSUMPTION OF NITROBACTER AGILIS CELLS IMMOBILIZED IN CARRAGEENAN: PART 2. MODEL EVALUATION}

\section{ABSTRACT}

A dynamic model, which predicts substrate and biomass concentration profiles across gel beads and from that the overall substrate consumption rate by the gel beads containing growing cells, was evaluated with immobilized Nitrobacter agilis cells in an air-lift loop reactor with oxygen as the limiting substrate. The model predictions agreed well with the observed oxygen consumption rates at three different liquid phase oxygen concentrations.

Image analysis showed that $90 \%$ of the immobilized cells after 42 days of cultivation was situated in the outer shells in a film of $140 \mu \mathrm{m}$, while the bead radius was about $1 \mathrm{~mm}$. The maximum biomass concentration in the outmost film of $56 \mu \mathrm{m}$ was $11 \mathrm{~kg} \cdot \mathrm{m}^{-3} \mathrm{gel}$. 


\section{INTRODUCTION}

Nitrification is a problematic process within waste water treatment due to the slow growth rate of the nitrifying organisms. The main species within this group are Nitrosomonas and Nitrobacter, which successively oxidize ammonia to nitrite and nitrate.

In previous studies we have shown that nitrifying bacteria can be retained in continuous-flow bioreactors by immobilization in a gel with maintenance of their nitrifying capacities..$^{47-51,54.60} \mathrm{It}$ was demonstrated that diffusion limitation increased with increasing amounts of immobilized cells. . $^{4,54}$ It was also shown that both Nitrosomonas europaea ${ }^{\infty 0}$ and Nitrobacter agilis ${ }^{50}$ can grow within the gel. For immobilized Nitrosomonas europaea, the effect of diffusion limitation on growth was described qualitatively. ${ }^{50}$ Initially, the cells were growing homogeneously across the beads, but as growth proceeded, a biomass density gradient developed, eventually resulting in a biofilm just below the surface of the gel beads. Accordingly, the reaction rate, which was originally limited by the kinetics of the cells, became diffusion limited.

For non-growing systems, substrate profiles across the beads and substrate fluxes into the beads were modelled and validated by De Gooijer et al. ${ }^{13} \mathrm{~A}$ homogeneous distribution of enzyme across the beads was assumed. A differential mass balance with simultaneous diffusion and substrate consumption was made and integrated numerically across the biocatalyst bead. External mass transport was also incorporated by using the film theory. This model has been extended to growing systems by coupling substrate consumption to growth via a yield coefficient. A negative net growth was allowed at low substrate concentrations and the local biomass concentration was limited to a maximum. ${ }^{14}$ It predicts the overall substrate consumption rate in addition to biomass and substrate concentration profiles across the beads.

This article describes the experimental evaluation of the latter model with immobilized Nitrobacter agilis. Immobilized cells were cultivated in continuous-flow airlift loop reactors with oxygen as the limiting substrate. Andrews ${ }^{3}$ defined the limiting substrate as the component whose concentration reaches zero first; this is the component with the lowest value for the product of effective diffusion coefficient; ;ield factor and the pertinent component concentration. In our case this value was always lower for oxygen than for nitrite. For that, as the nitrification capacity of the system 
increased, the nitrite concentration of the influent was increased in such a way that nitrite in the reactor never was limiting. The oxygen concentration in the liquid phase was kept at a constant level. The oxygen consumption rates at various constant oxygen concentrations were determined and compared with model predictions. Biomass concentration profiles across the gel beads were determined by image analysis to estimate the local maximum immobilized biomass concentration.

\section{MATERIALS AND METHODS}

\section{Organism and culture conditions}

Nitrobacter agilis (ATCC 14123) was cultivated in a $5-\mathrm{dm}^{3}$ batch culture. The composition of the medium was based on studies on nutrient requirements. ${ }^{2,6,10,34,43,53}$ The medium contained per $\mathrm{m}^{3}$ of demineralized water: $14.5 \mathrm{~mol} \mathrm{NaNO} ; 0.21 \mathrm{~mol}$ $\mathrm{MgSO}_{4} ; 5 \mathrm{~mol} \mathrm{KH}_{2} \mathrm{PO}_{4} ; 5 \mathrm{~mol} \mathrm{Na}_{2} \mathrm{HPO}_{4} ; 1 \mathrm{mmol} \mathrm{Na} \mathrm{MoO}_{4} ; 0.015 \mathrm{mmol} \mathrm{ZnSO} ; 0.016$ mmol CuSO${ }_{4}$ and $5 \mathrm{mmol} \mathrm{CaCl}_{2}$. Per mole nitrite $0.02 \mathrm{~mol} \mathrm{NaHCO}_{3}$ was added. The $\mathrm{pH}$ was adjusted to 7.8 with $2 \mathrm{~N} \mathrm{KOH}$. The medium was inoculated with about $10 \%$ $(\mathrm{v} / \mathrm{v})$ of cell culture. Every 3 days $72.5 \mathrm{mmol}$ of $\mathrm{NaNO}_{2}$ was added to obtain dense cultures. After 9 days the culture was harvested. Cultivation was executed at $30^{\circ} \mathrm{C}$ in the dark to prevent light inhibition. ${ }^{9,32,62}$

\section{Immobilization procedure}

The cell suspension was centrifuged during 10 minutes at $16,300 \mathrm{~g}$ and $5^{\circ} \mathrm{C}$. The cells were washed with $15.4 \mathrm{mM} \mathrm{NaCl}$ solution.

A 3\% $\kappa$-carrageenan solution (Genugel X0828, A/S Kobenhavns Pektinfabrik, DK Lille Skensved) was mixed gently with the washed suspension such that a $2.6 \%$ carrageenan solution was obtained. The carrageenan solution and the cell suspension were kept at $35^{\circ} \mathrm{C}$.

Immobilization was performed with a resonance nozzle ${ }^{25}$ at $35^{\circ} \mathrm{C}$. Drops were collected in $0.75 \mathrm{M} \mathrm{KCl}$ at $5{ }^{\circ} \mathrm{C}$. To obtain perfect spheres a decane layer was brought upon the $\mathrm{KCl}$ solution as proposed by Buitelaar et al." The decane and the $\mathrm{KCl}$ solution were kept at $5^{\circ} \mathrm{C}$ in order to initiate the gelation. Decane is non-toxic due to 
its high $\log P$ value. ${ }^{27}$

The average bead diameter was $2.04 \mathrm{~mm}( \pm 0.22 \mathrm{~mm})$ and the initial biomass concentration in the beads was $4.5 \times 10^{-3} \mathrm{~kg} . \mathrm{m}^{-3}$.

\section{Immobilized cell cultivation}

Immobilized cells were cultivated in continuous-flow air-lift loop reactors (two of $3.40 \mathrm{dm}^{3}$ and one of $2.35 \mathrm{dm}^{3}$ ). The experimental set up is shown schematically in Fig. 1.

The reactors were coupled to a Programmable Logic Controller (PLC Melsec-G, Mitsubishi G62P). Communication with the PLC was accomplished via a personal computer. The oxygen concentration in each reactor was monitored (WTW Oxy 219/9OR) and the signal sent to the PLC. Depending on the difference between the measured value and the set point, the PLC adjusted 2 mass flow controllers (Brooks instruments $5850 \mathrm{TR}$ ); one for air and one for nitrogen. The total gas flow into the reactors was thus kept constant $\left(5.8 \mathrm{~cm}^{3} . \mathrm{s}^{-1}\right.$ for the $3.4 \mathrm{dm}^{3}$ reactors and $4.2 \mathrm{~cm}^{3} . \mathrm{s}^{-1}$ for the $2.35 \mathrm{dm}^{3}$ reactor) in order to maintain constant mass transfer properties across the stagnant layer surrounding the beads.

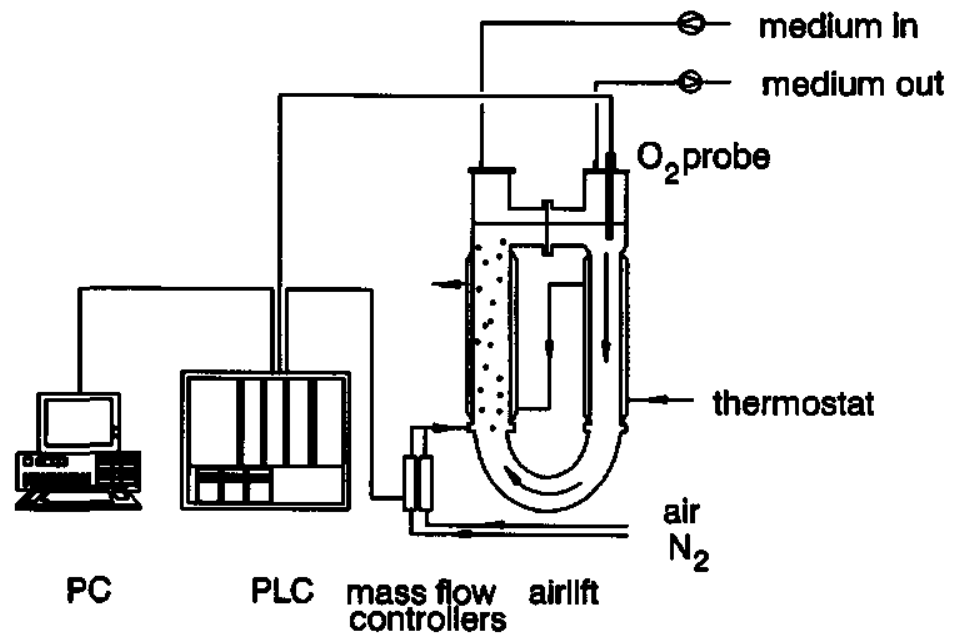

Fig. 1: Experimental set up of the immobilized cell cultivation. 
In three experiments, the bulk oxygen concentration was kept at 0.012 (smallest reactor), 0.038 and $0.080 \mathrm{~mol} . \mathrm{m}^{-3}$, respectively. The influent nitrite concentration was adjusted daily so as to keep the reactor concentration between 3 and $15 \mathrm{~mol}^{-3} \mathrm{~m}^{-3}$. In this way oxygen is the limiting substrate and there are no toxicity problems of nitrite.

The medium contained per $\mathrm{m}^{3}$ of demineralized water: a variable amount of $\mathrm{KNO}_{2}$; $0.21 \mathrm{~mol} \mathrm{MgSO}_{4} ; 5 \mathrm{~mol} \mathrm{KH}_{2} \mathrm{PO}_{4} ; 5 \mathrm{~mol} \mathrm{~K}_{2} \mathrm{HPO}_{4} ; 1 \mathrm{mmol} \mathrm{Na}_{2} \mathrm{MoO}_{4} ; 0.015 \mathrm{mmol} \mathrm{ZnSO}{ }_{4} ;$ $0.16 \mathrm{mmol} \mathrm{CuSO}_{4} ; 5 \mathrm{mmol} \mathrm{CaCl}_{2}$ and $5 \mathrm{~mol}$ of KCl . Per mole nitrite $0.02 \mathrm{~mol}$ of $\mathrm{KHCO}_{3}$ was added. The $\mathrm{pH}$ was adjusted to 7.8 with $2 \mathrm{~N} \mathrm{KOH}$. Cultivation was executed at $30^{\circ} \mathrm{C}$ in the dark to prevent effects of light inhibition.

In the reactor operated at $0.012 \mathrm{~mol} \mathrm{O}_{2} \cdot \mathrm{m}^{-3}$, the dilution rate was $4.6 \times 10^{-5} \mathrm{~s}^{-1}$ and the reactor gel load $25 \%(\mathrm{v} / \mathrm{v})$. For the reactors operated at 0.038 and $0.080 \mathrm{~mol} \mathrm{O}_{2}$. $\mathrm{m}^{-3}$, the dilution rate based on the liquid-phase volume was $4.0 \times 10^{-5} \mathrm{~s}^{-1}$ and the reactor gel load was $15 \%(\mathrm{v} / \mathrm{v})$. In preliminary runs it appeared that the oxygen transfer rate from the gas phase to the liquid phase at a gel load of $25 \%(\mathrm{v} / \mathrm{v})$ was too low to keep the liquid phase oxygen concentration at 0.038 and $0.080 \mathrm{~mol} . \mathrm{m}^{-3}$, respectively, during the entire experiment. Therefore the gel load was lowered to 15 $\%(v / v)$ for these two cases.

\section{Oxygen consumption rate}

Nitrite oxidation by Nitrobacter requires stoichiometric amounts of oxygen. ${ }^{129.30 .44}$ Thus to estimate the oxygen consumption rate, the nitrite consumption rate per amount of gel was determined regularly. Reactor nitrite concentrations were determined at least 24 hours after increasing the influent nitrite concentration, such that refreshment of the medium had occurred four times and a nitrogen balance across the reactor could be made.

Nitrite and nitrate concentrations in influent and effluent were determined ${ }^{18}$ using a continuous-flow analysis system (Technicon Auto Analyser 2). For nitrate analysis the samples first passed through a copper-coated cadmium column in order to reduce the nitrate to nitrite. By addition of $\alpha$-naphtylamide in acid medium, the nitrite forms a red diazo compound, that was measured at $550 \mathrm{~nm}$. 


\section{Biomass concentration}

Overall viable biomass estimates were made by activity assays in a biological oxygen monitor as described before. ${ }^{54}$ In a reaction cuvette $50-200$ beads and $4 \mathrm{~cm}^{3}$ potassium phosphate buffer $\left(0.1 \mathrm{~mol} . \mathrm{dm}^{-3}, \mathrm{pH} 7.8\right)$ were suspended and saturated with air. If the activity exceeded $0.002 \mathrm{~mol}^{-3} \mathrm{~m}^{-3}$ gel. $\mathrm{s}^{-1}$, pure oxygen was used to prevent mass transfer limitations. Through a small opening a concentrated $\mathrm{KNO}_{2}$ solution was injected to a final concentration of $20 \mathrm{~mol}^{-3} \mathrm{~m}^{-3}$ and the decrease in oxygen concentration at $30^{\circ} \mathrm{C}$ was recorded.

The activity per amount of gel was converted to a biomass dry weight concentration by dividing by the specific activity. The specific activity of Nitrobacter agilis is $7 \times 10^{-3} \mathrm{~mol} . \mathrm{kg}^{-1} . \mathrm{s}^{-1}$ at a nitrite concentration of $20 \mathrm{~mol} . \mathrm{m}^{-3} .10,50$

Regularly the activity in the bulk liquid phase was measured. In that case the assay was executed in culture medium which was concentrated first by centrifugation.

\section{Determination of biomass profile}

After 42 days of cultivation at a liquid phase oxygen concentration of $0.080 \mathrm{~mol}$. $\mathrm{m}^{-3}$, samples of the beads were used for image analysis. Image analysis was executed on sections through the centre of the beads by sectioning with an ultramicrotome.

In order to obtain thin sections the beads were dehydrated and embedded in a resin. Chemical fixation prior to dehydration appeared to be necessary. The procedure was based on the work of Van Neerven et $a I^{55}$ The beads were washed twice for 5 minutes in buffer (0.1 M Na-cacodylate, $\mathrm{pH} 7.5)$. To keep the carrageenan beads rigid, the Na-cacodylate buffer was supplemented with $0.1 \mathrm{~mol} . \mathrm{m}^{-3} \mathrm{KCl}$ during all washing and fixation steps. A first fixation of $1.5 \mathrm{~h}$ was executed in the same buffer containing $2.5 \%(\mathrm{w} / \mathrm{v})$ glutaraldehyde. After washing the samples 3 times for 10 minutes in the $\mathrm{Na}$-cacodylate buffer, they were placed for a second fixation of $1.5 \mathrm{~h}$ in this buffer containing $1.0 \% \mathrm{OsO}_{4}(\mathrm{w} / \mathrm{v})$. The beads were washed again in the buffer 3 times for 10 minutes prior to dehydration in a series of gradually increasing ethanol concentrations: $10,30,50,70,90$ and twice $100 \%$. A decreasing $\mathrm{KCl}$ gradient from 0.09 to $0.03 \mathrm{~mol}$. $\mathrm{m}^{-3}$ was used in the increasing ethanol series of $10,30,50$ and 70 $\%$. No $\mathrm{KCl}$ was added in the two ultimate dehydration steps. Each step was allowed to equilibrate for 10 minutes. 
The dehydrated beads were embedded in London Resin White (Bio-rad). Therefore, the beads were placed in ethanol-London Resin White solutions in the ratios $5: 1,3: 1$, 1:1 and 1:3, respectively, before treatment with pure London Resin White. Each step was allowed to equilibrate for 30 minutes. Treatment with pure London Resin White was executed in two steps. The first step for $60 \mathrm{~min}$ and the second for $24 \mathrm{~h}$. Polymerization of the resin took place in a gelatine mould at $60^{\circ} \mathrm{C}$ during $24 \mathrm{~h}$.

Sectioning was executed on a LKB 8800 Ultramicrotome III with a glass knife. Sections were stained with toluidine blue to improve the contrast between the gel and the colonies. The samples were observed at a magnitude of 40 on a light microscope and photographs were made with a Kodak Technical Pan film 2415 at 50 ASA. The prints (final magnification 150x) were used for image analysis with a Quantimet 970 (Cambridge Instruments). By image analysis the coordinates of the centres of the colonies were determined in relation to the centre of the bead. Also the radii of the colonies were determined. For determination of the volumetric fraction of colonies the beads were divided into fictive shells by test lines. In those shells the areal density was determined according to the principle of Rosiwal, which is that the areal density is equal to the fractional length of a test line that intersects the objects. ${ }^{58}$ In this case the test line is a circle with a fixed distance to the centre of the beads (Fig. 2). The fraction

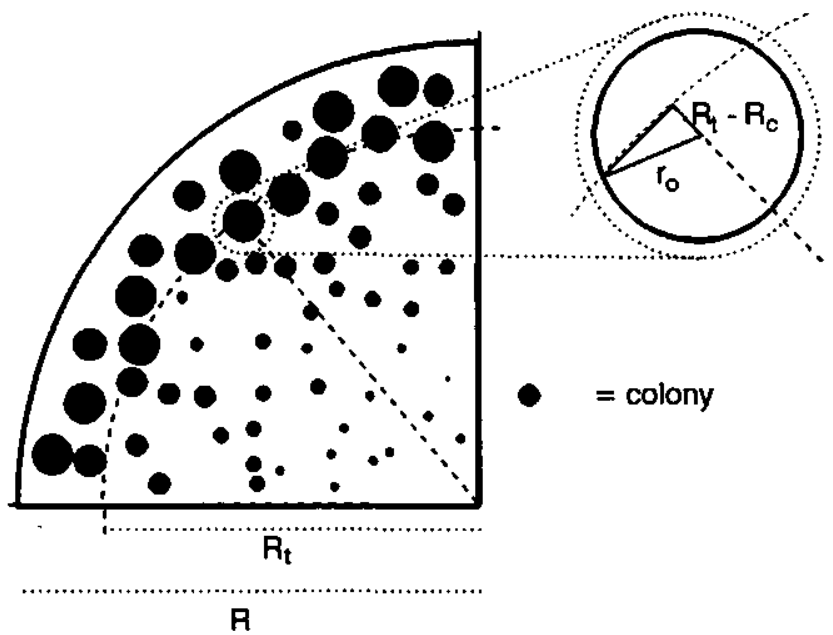

Fig. 2: Procedure for determination of the volumetric fraction of biomass: $r_{0}$ observed colony radius; $\boldsymbol{R}_{\mathrm{e}}$, distance between centre of the colony and the centre of the bead; $\boldsymbol{A}$, bead radius; $R_{t}$, radius test line. 
of the test line that sections the colonies can be calculated from the distance from the centre of the bead to the centre of the colony minus the distance from the centre of the bead to the drawn test line and the colony radius. In the core section of the beads the areal density was directly determined in three area classes, because the distribution of the colony fraction is relatively random there. In thin slices the areal density is equal to the volumetric density according to the principle of Delesse. ${ }^{58}$

As the observed areas are projections of the observed colonies situated in slices with a thickness $L$, it may be necessary to correct for over-estimations as more images are projected for thicker slices (the Holmes effect) and under-estimations as images can overlap. ${ }^{21,52,58,59}$

As the slices are thin compared to the colony radii, overlap may be neglected.${ }^{59}$ For the Holmes effect, the observed radii can be corrected by a factor defined as ${ }^{59}$

$$
c=\frac{\pi}{\pi+2 \frac{L}{r_{c}}}
$$

As the observed colony radii are expectations of the colony radii, the colony radii can be obtained from

$$
E(\underline{D})=2 r_{c} \frac{1+\frac{\pi}{2} \frac{r_{c}}{L}}{1+2 \frac{r_{c}}{L}}
$$

and the observed projections can be corrected individually.

\section{Starvation under oxygen depletion}

For determination of maintenance energy Nitrobacter agilis was cultivated batch wise in a stirred fermenter (at $450 \mathrm{rpm}$ ). Culture conditions were as described above. After one week of cultivation the oxygen supply was stopped and nitrogen gas was 
supplied instead. The decrease in potential activity was taken as a measure for the specific biomass degradation rate, as can be obtained directly from the relation of Herbert $^{22}$ if the substrate concentration is zero:

$$
\ln \frac{X_{t}}{X_{0}}--m r_{x s} t
$$

Data for molar substrate yield were obtained from the literature.

Activity was determined as described before, except that it was directly measured in the culture medium.

\section{RESULTS AND DISCUSSION}

\section{Input parameters}

All input parameters used in the dynamic mathematical model were obtained from the literature or determined in separate experiments.

Effective diffusion coefficient $\left(D_{e, 8}\right)$

The effective diffusion coefficient for oxygen in $\kappa$-carrageenan beads was determined by Hulst et al. ${ }^{24} \mathrm{Up}$ to a polymer concentration of $3 \%$ a constant effective diffusivity of $1.58 \mathrm{x}$ $10^{-9} \mathrm{~m}^{2} . \mathrm{s}^{-1}$ was found. This value was used in the present work for a zero immobilized biomass concentration (Table I), since a carrageenan concentration of $2.6 \%$ was used.

The effective diffusion coefficient is
Table I: Input parameters (references are glven in text)

effective diffusion coefficient

$$
D_{a, g} \quad\left(m^{2} . s^{-1}\right) \quad 1.58 \times 10^{-9}
$$

liquid-solid mass transfer coefficlent

$$
\begin{array}{lll}
k_{h, s} & \left(\mathrm{~m}^{-1}\right) & 3.7 \times 10^{-5}
\end{array}
$$

kinetic parameters

$\begin{array}{lll}\mu_{\max } & \left(\mathrm{s}^{-1}\right) & 1.0 \times 10^{-5} \\ K_{s} & \left(\mathrm{~mol}^{-3} \mathrm{~m}^{-3}\right) & 0.017 \\ Y_{m s} & \left(\mathrm{~kg} . \mathrm{mol}^{-1}\right) & 1.16 \times 10^{-3} \\ m & \left(\mathrm{~mol} . \mathrm{kg}^{-1} . \mathrm{s}^{-1}\right) & 1.1 \times 10^{-3}\end{array}$

biomass concentrations

$\begin{array}{lll}X_{0} & \left(\mathrm{~kg} \cdot \mathrm{m}^{-3}\right) & 4.5 \times 10^{-3} \\ X_{\max } & \left(\mathrm{kg} \cdot \mathrm{m}^{-3}\right) & 11 \\ X_{p, \max } & \left(\mathrm{kg} \cdot \mathrm{m}^{-3}\right) & 950\end{array}$


affected by the concentration of biomass in the support material. ${ }^{12,16,23,31,42}$ As stated by De Gooijer et al., ${ }^{14}$ the effective diffusion coefficient will be zero if all pores in the gel are completely filled by bacterial cells, with no intercellular space left. At the gel concentration used, the available pore volume will be at least $95 \%$ of the total gel volume and the pores will be completely filled if the biomass concentration is about $950 \mathrm{~kg} . \mathrm{m}^{-3}$. This value is defined as the maximum physically attainable biomass concentration $X_{p, \max }$.

\section{Liquid-solid mass transfer coefficient $\left(k_{1,2}\right)$}

From the Biot number it can be estimated whether external mass transfer has to be taken into consideration. If $\mathrm{Bi}$ approaches zero, all resistance is situated in the stagnant layer, and if it reaches infinite values the resistance across the stagnant layer may be neglected. The Biot number was estimated to be 25 in our case. The value will be much lower when only the active layer is considered. This means that external mass transfer certainly may not be neglected, such that $k_{1, s}$ is an important factor. For calculation of the liquid/solid mass transfer coefficient $\left(k_{1, s}\right)$ the relation of Ranz and Marshall ${ }^{37}$ was used:

$$
k_{L s}=\frac{D_{L}\left(2+0.6 S c^{\frac{1}{3}} R e^{\frac{1}{2}}\right)}{d_{p}}
$$

The Reynolds number was calculated from the Galileo number. Relations between $\mathrm{Re}$ and Ga can be derived easily for the Stokes, Newton and intermediate regimes. ${ }^{7}$ It was assumed that the particles move with the rate of free fall. Re thus calculated is 58 , which means that Ranz and Marshall is applicable. ${ }^{37}$ Equation (4) gives with $\mathrm{Re}=58$ a mass-transfer coefficient of $3.7 \times 10^{-5} \mathrm{~m}^{-\mathrm{s}^{-1}}$ (Table $\mathrm{I}$ ), which gives good predictions of the overall oxygen consumption rates in all experiments as will be discussed.

In first instance the method of Kolmogoroff as used by Sänger and Deckwer ${ }^{41}$ for a bubble column and extended for an air-lift loop reactor by Wagner and Hempel ${ }^{57}$ seemed more appropriate to us. Kolmogoroff gave a relation between the energy dissipation and the Sherwood number. However, poor model predictions were 
obtained if those relations were used. This can be explained by differences in superficial gas velocities $\left(u_{\mathrm{g}}\right)$, which were minimal double of what we used $(0.0018 \mathrm{~m}$. $\left.\mathrm{s}^{-1}\right)$. When the energy dissipations are compared, the differences are even much bigger. They found an energy dissipation $(\epsilon)$ between 0.25 and $0.52 \mathrm{~m}^{2} . \mathrm{s}^{-3}$, while we calculated for our experiments $0.011 \mathrm{~m}^{2} . \mathrm{s}^{-3}$, which makes it inappropriate to apply their equations in our regime.

Maximum specific growth rate $\left(\mu_{\max }\right)$

Literature data for maximum specific growth rates range from ${ }^{15,17,20,26,38} 0.98 \times 10^{-5}$ to $2.3 \times 10^{-5} \mathrm{~s}^{-1}$. In our experiments $\mu_{\max }$ was taken to be $1.0 \times 10^{-5} \mathrm{~s}^{-1}$, a value that was found by Tramper and Grootjen ${ }^{50}$, who used the same strain (Table I).

\section{Monod constant $\left(K_{\diamond}\right)$}

Most kinetic studies with nitrifying bacteria were executed with the nitrogenous compound as the limiting substrate. The few data known for oxygen as limiting substrate were obtained from activity assays instead of growth experiments..$^{10,33,35,45,61}$ An overview of the effect of the dissolved oxygen concentration on nitrification has been given by Stenstrom and Poduska. ${ }^{45}$ The general range for $K_{s}$ appears to be $0.009-0.026 \mathrm{~mol} . \mathrm{m}^{\cdot 3} .^{10,33,61}$ Sensitivity analysis demonstrated that within this range there was little effect on the predicted oxygen consumption rate. ${ }^{14}$ Therefore, an average $K_{s}$ value of $0.017 \mathrm{~mol} . \mathrm{m}^{-3}$ was chosen (Table I).

Yield $\left(\gamma_{x y}\right)$ and maintenance $(m)$ coefficients

In the present model maintenance energy plays an important role, because this factor determines the negative growth of cells that live under oxygen depletion. Almost no values are available for maintenance coefficients $(m)$. Apart from that, in studies where maintenance was determined, nitrite was taken as the limiting substrate. The same holds for the yield coefficients $\left(Y_{x s}\right)$. Available data were recalculated to oxygen yields and maintenance coefficients according to the reaction stoichiometry. As general composition formula for biomass the relation as given by Roels ${ }^{39}\left(\mathrm{CH}_{1.8} \mathrm{O}_{0.5} \mathrm{~N}_{0.2}\right)$ and the cell weight as given by Lees and Simpson ${ }^{30}\left(10^{-10} \mathrm{mg} / \mathrm{cell}\right)$ were used. 
Keen and Prosser ${ }^{26}$ found yield coefficients of $19.6 \times 10^{-3}$ and $3.92 \times 10^{-3} \mathrm{~kg} \cdot \mathrm{mol}^{-1}$

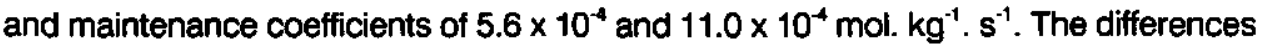
in their results were caused by the fact that two different calculation procedures were used for the same set of data. The first values were calculated by an iterative procedure and the latter by linear regression analysis of the double reciprocal plot. There is doubt about their results obtained by iteration, because the product of this growth yield $\left(Y_{x s}\right)$ and maintenance coefficient $(m)$, i.e., the specific biomass degradation rate as defined by Herbert, ${ }^{22}$ is higher than the maximum specific growth rate, or in other words, even at a maximum specific growth rate the biomass decay rate was higher than the growth rate.

Helder and de Vries ${ }^{20}$ and Belser ${ }^{6}$ found values for the yield coefficient of $0.98 \times 10^{\circ}$ ${ }^{3}$ and $1.16 \times 10^{-3} \mathrm{~kg} \mathrm{~mol}^{-1}$, respectively. As Belser ${ }^{6}$ studied in our opinion yield most extensively, this value has been taken as input parameter (Table l).

From the work of Chiang (1969) as reported by Belser a maintenance of $2.78 \mathrm{x}$ $10^{-3} \mathrm{~mol}^{\mathrm{kg}} \mathrm{kg}^{-1} \mathrm{~s}^{-1}$ can be estimated. When a yield factor of $1.16 \times 10^{-3} \mathrm{~kg} . \mathrm{mol}^{-1}$ is assumed and with the maintenance coefficient given by Belser ${ }^{5}$, the specific biomass degradation rate is $32 \%$ of the maximum specific growth rate. When the regression results of Keen and Prosser ${ }^{26}$ apply, this ratio is $12.8 \%$. Laudelout et al. ${ }^{28}$ found a very broad range between 11 and $53 \%$. Because no more values were found in the literature, this parameter has been estimated in a separate experiment. Our model ${ }^{14}$ involves a combination of the models of Pirt ${ }^{36}$ and Herbert ${ }^{22}$, as proposed by Beeftink et $a l^{4}$ Determination of maintenance energy was done with the bacteria under oxygen depletion. In that region the model of Herbert ${ }^{22}$ is applicable and the specific biomass degradation rate can directly be obtained from the observed decay rate (Equation 3).

The decrease in activity under oxygen depletion is shown in Fig. 3. The observed specific degradation rate was $12.8 \%$ of the maximum specific growth rate, which means that the maintenance coefficient of $1.1 \times 10^{-3} \mathrm{~mol}^{\mathrm{kg}} \mathrm{kg}^{-1} . \mathrm{s}^{-1}$ as given by Keen and Prosser ${ }^{26}$ is appropriate as input parameter (Table I).

With the chosen set of values model predictions were obtained which compared well to experimental results as will be shown. It was also shown that in the applied regimes the predicted oxygen consumption rates were relatively insensitive to changes in values of the yield and maintenance coefficients. ${ }^{14}$ 


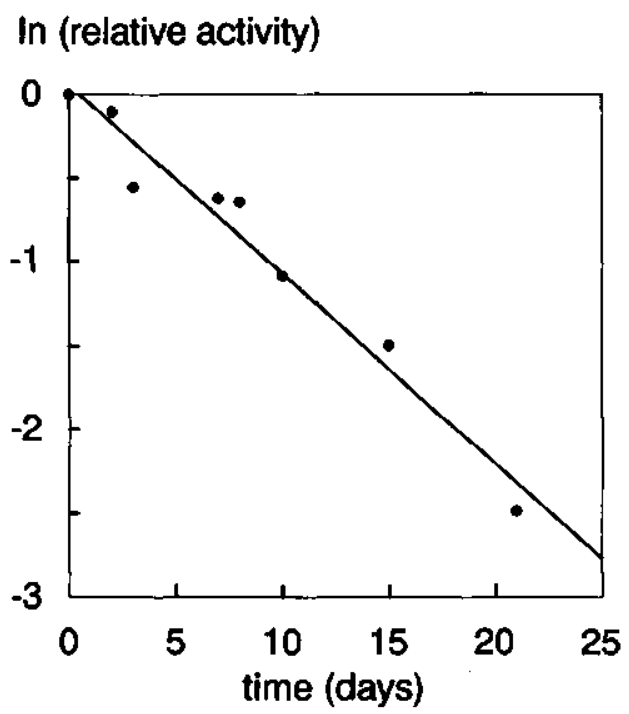

Fig. 3: Activity decrease of Nitrobacter agilis under oxygen depletion.

\section{Performance immobilized cell reactor}

\section{Oxygen consumption rate}

In three separate experiments the cells were cultivated in continuous-flow air-lift loop reactors. Daily results of the experiment with the highest oxygen concentration $\left(0.080 \mathrm{~mol}^{\mathrm{m}} \mathrm{m}^{-3}\right)$ are given in Fig. 4 . The influent nitrite concentration was $4 \mathrm{~mol} . \mathrm{m}^{-3}$ at start-up. After 4 days, the effluent nitrite concentration decreased, and the influent concentration was increased to $10 \mathrm{~mol} . \mathrm{m}^{-3}$. Subsequently, it was adjusted every day to keep the effluent nitrite concentration above $3 \mathrm{~mol} . \mathrm{m}^{-3}$. As shown, in only a few days this concentration was lower. The influent nitrite concentration was raised almost linearly until 17 days after start-up. From that day on the influent nitrite concentration could be kept at $60 \mathrm{~mol} . \mathrm{m}^{-3}$ as no further increase in substrate consumption was observed.

Two additional experiments were executed with bulk oxygen concentrations of 0.012 and $0.038 \mathrm{~mol}^{-3}$, and a similar reactor performance was observed. At these 


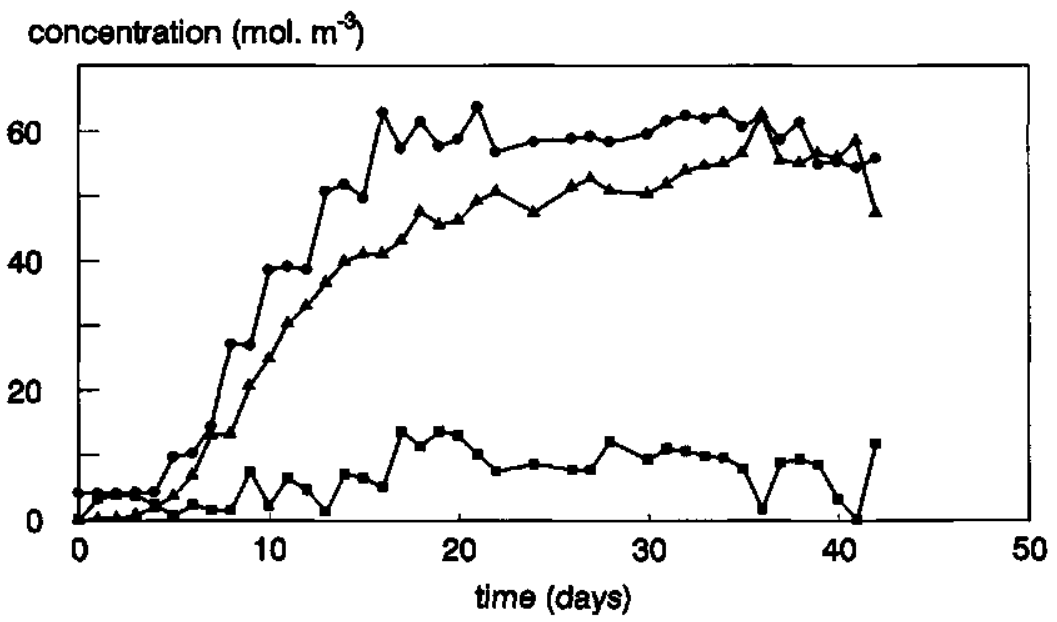

Fig. 4: Influent nitrite $(O)$ and effluent nitrite $(D)$ and nitrate $(\Delta)$ concentrations in a continuous flow experiment at a liquid phase oxygen concentration of $0.08 \mathrm{~mol} . \mathrm{m}^{-3}$.

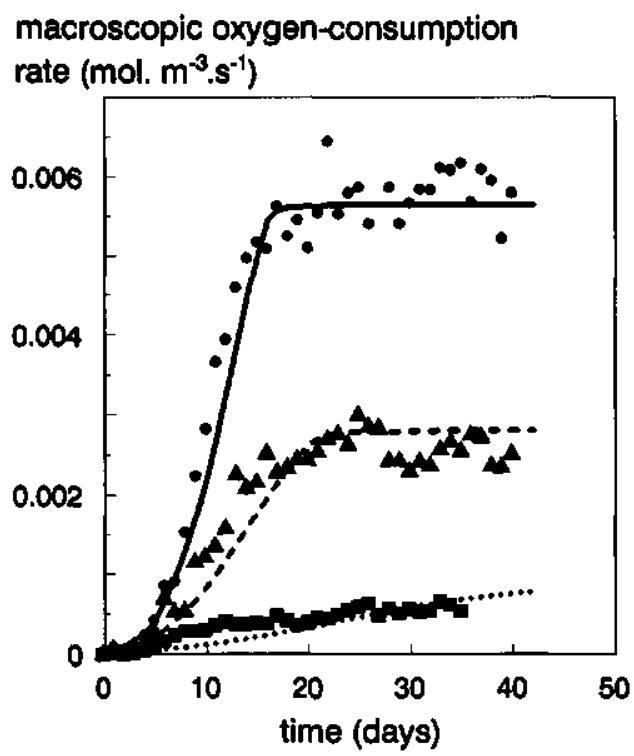

Fig. 5: Observed and predicted overall consumption rates in the biocatalyst beads at different liquid phase oxygen concentrations: $(E, \ldots) 0.012 \mathrm{~mol}^{-3} \mathrm{~m}^{-3},(\Lambda,-) 0.038 \mathrm{~mol}^{-3} \mathrm{~m}^{-3}$ and $(\Theta,-)$ $0.08 \mathrm{~mol} . \mathrm{m}^{-\mathrm{s}}$. 
oxygen concentrations the influent nitrite concentration could be kept constant after a while at levels of about 10 and $30 \mathrm{~mol} . \mathrm{m}^{-3}$, respectively.

From the influent and effluent nitrite concentrations, the dilution rate and the amount of gel, the overall nitrite consumption rates of the beads were calculated. With that, the overall oxygen consumption rate of the beads was estimated. These rates are given for the three experiments in Fig. 5, which shows that the experimental results and the model predictions as described by De Gooijer et al. ${ }^{14}$ compare very well. It is also clearly shown that at higher oxygen concentrations the reactor capacity increased.

Biomass profiles and maximum biomass concentration $\left(\chi_{\text {max }}\right)$

The overall viable biomass concentrations were estimated by activity assays. The development of the potential activity for all experiments is shown in Fig. 6. Beads obtained at the end of the experiment with the highest liquid phase oxygen concentration $\left(0.080 \mathrm{~mol} . \mathrm{m}^{-3}\right)$ were used to determine the biomass profile and the maximum biomass concentration. The overall average biomass concentration in these beads at that time was $3.7 \mathrm{~kg} . \mathrm{m}^{-3}$.

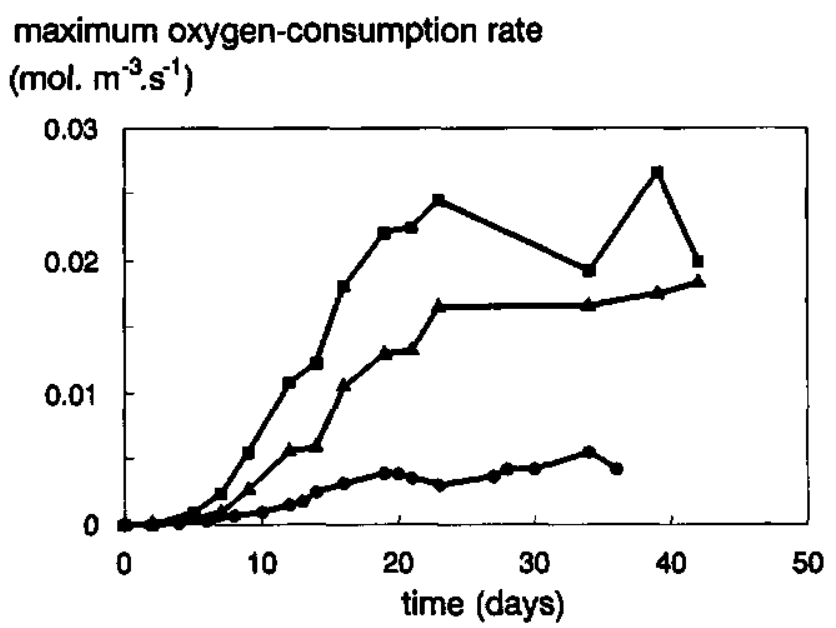

Fig. 6: Overall viable biomass concentration versus time in the air-lift loop reactors with bulk oxygen concentrations of $0.012(0), 0.038(\Lambda)$ and $0.080(\square)$ mol. $m^{-4}$, measured as potential activity. 
Sections with a thickness of 3 and $4 \mu \mathrm{m}$, respectively, were analyzed. Fig. 7 shows one of the two results directly obtained from image analysis. The apparent colony radii are given as a function of the radial position within the bead. Those results were converted into relative biomass concentrations as shown in Fig. 8 for both samples. It is shown that $90 \%$ of the immobilized biomass was situated in an outmost shell of about $140 \mu \mathrm{m}$. The maximum, with a thickness of about $20 \mu \mathrm{m}$, was reached between a relative radius of 0.94 and 0.96 . At a relative radius exceeding 0.96 , the biomass concentration was decreasing. This phenomenon was also observed by Salmon..$^{40}$ In the model, ${ }^{14}$ however, we assumed that the biomass concentration in the outer shells reached a constant maximum.

From the sections maximum biomass concentrations were calculated, which were used as an input parameter in our model. ${ }^{14}$ The concentration under the peaks were 17.8 and $17.3 \mathrm{kg.} \mathrm{m}^{3}$, respectively. When the concentration was averaged from the maximum to the bead surface (between a relative bead radius of 0.94 and 1.0), the biomass concentration was in both cases $11 \mathrm{~kg}^{-3} \mathrm{~m}^{-3}$ in a shell of $56 \mu \mathrm{m}$. The latter value was used as input parameter, and gave acceptable model predictions of the oxygen consumption rates. This value compares well with model predictions of Gujer and Boller, ${ }^{19}$ who reported values up to $14 \mathrm{~kg} . \mathrm{m}^{-3}$. For the conversion of the apparent

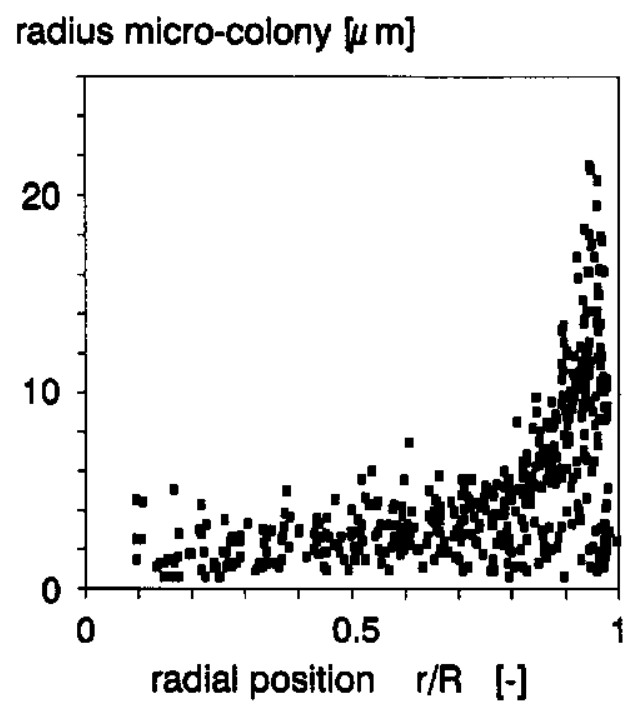

Fig. 7: Measured colony radii as a function of radial position within the beads. 


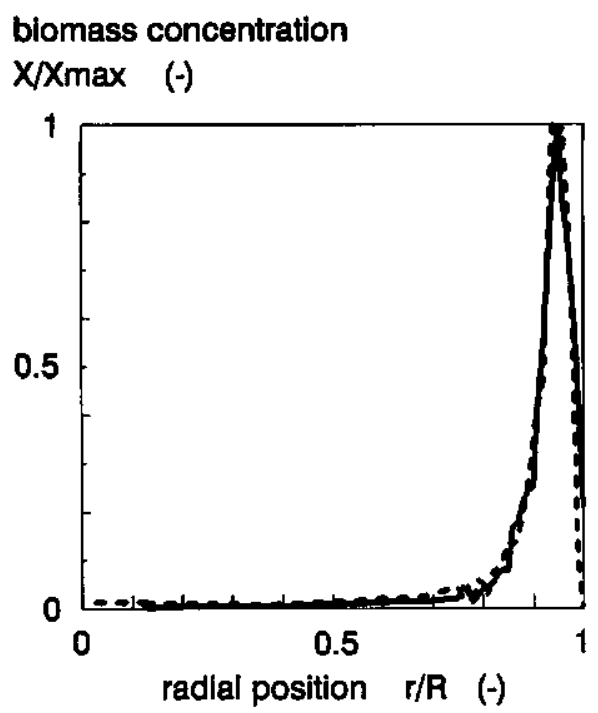

Fig. 8: Biomass profile as a function of radial position within the beads.

colony radii to a relative biomass concentration, the following remarks apply. As the sections were not infinitely thin, the principle of Delesse was not directly applicable. Correction for the Holmes effect did lead to a $17 \%$ lower volumetric fraction at a relative radius higher than 0.85 . At a radius lower than 0.85 , correction did lead to 44 $\%$ reduction. In the latter part of the bead however, only $10 \%$ of the biomass was situated. During preparation of the beads shrinkage occurred. The radius decreased 16-19\%. We have assumed that there was no difference in shrinkage between colonies and beads. No protrusions were formed as the result of the fact that gel shrinkage was higher than colony shrinkage. There were no non-filled holes observed from which colonies had disappeared due to the fact that colony shrinkage was higher than gel shrinkage.

A possible explanation for a decreasing biomass concentration in the most outer shell can be given by the fact that the colonies will grow out of the gel beads. In the immobilization procedure the bacterial cells are distributed homogeneously across the gel and are closely surrounded by the polymer matrix. Because of growth, single cells will form expanding colonies. The formed micro-colonies thus provide for their own space in the gel, at the expense of pressure increase. ${ }^{46}$ Near the gel surface colony 
discharge due to this pressure build-up may have contributed to the decrease in peripheral biomass concentration. In future research, the present model will be extended and a biomass release term will be included.

Biomass release influences the reactor nitrite consumption. This effect has been considered for steady states. ${ }^{8.56}$ At high dilution rates, however, the contribution of suspended biomass is negligible. This was checked in our experiments. The discharged effluent did not show activity. At lower dilution rates this effect can be considerable. This effect will also be added to the model in order to come to an overall dynamic reactor model for all regimes.

\section{APPENDIX: DIMENSIONLESS NUMBERS}

Biot:

$$
B i-\frac{k_{l, s} 0.5 \cdot d_{p}}{D_{e, s}}
$$

Galileo:

$$
G a=d_{p}{ }^{3} g \frac{\rho_{p}-\rho_{i}}{\eta^{2}}
$$

Reynolds:

$$
R e-\frac{\rho, u d_{p}}{\eta}
$$

Schmidt:

$$
S c=\frac{\nu}{D_{1}}
$$




\section{NOMENCLATURE}

$\mathrm{Bi}=$ Biot number

C = correction factor for the Holmes effect

$D_{\iota} \quad=$ diffusion coefficient liquid

$D_{e} \quad=$ effective diffusion coefficient $\left(m^{2} \cdot s^{-1}\right)$

$D_{\theta, g} \quad=$ effective diffusion coefficient in gel $\left(m^{2} \cdot s^{-1}\right)$

$d_{p} \quad=$ particle diameter

$E(\underline{D})=$ expectation of observed diameter

$\mathrm{Ga}=$ Galileo number

$g \quad=$ gravitational acceleration

$k_{l, s}=$ liquid-solid mass transfer coefficient (m. $\left.s^{-1}\right)$

$K_{s}=$ Monod constant (mol. $\left.\mathrm{m}^{-3}\right)$

$L \quad=$ section thickness

$m \quad=$ maintenance coefficient (mol. $\mathrm{kg}^{-1} \cdot \mathrm{s}^{-1}$ )

$r_{c}=$ colony radius

$r_{0} \quad=$ observed colony radius

$R=$ bead radius

$\boldsymbol{R}_{c}=$ distance centre colony to centre of the bead

$R_{t} \quad=$ radius test line

$R e=$ Reynolds number

$S_{b} \quad=$ substrate concentration in the bulk

Sc $=$ Schmidt number

$t=$ time

$u_{\mathrm{g}} \quad$ = superficial gas velocity

$x=$ biomass concentration

$x_{0}=$ biomass concentration at $t=0$

$x_{\max }=$ maximum biomass concentration

(kg. $\left.\mathrm{m}^{-3}\right)$

$X_{\text {pmax }}=$ maximum physically attainable biomass concentration

(kg. $\left.\mathrm{m}^{-3}\right)$

$X_{t}=$ biomass concentration at $t=\mathbf{t}$

$Y_{x s} \quad=$ molar substrate yield

$\epsilon \quad=$ energy dissipation rate (mol. $\left.\mathrm{kg}^{-1}\right)$ $\left(m^{2} \cdot s^{-3}\right)$

$\mu_{\max }=$ maximum specific growth rate 


$\begin{array}{rlr}v & =\text { kinematic viscosity } & \left(\mathrm{m}^{2} \cdot \mathrm{s}^{-1}\right) \\ \eta & =\text { dynamic viscosity } & \left(\mathrm{kg} \cdot \mathrm{m}^{-1} \cdot \mathrm{s}^{-1}\right) \\ \rho_{l} & =\text { density liquid phase } & \left(\mathrm{kg} \cdot \mathrm{m}^{-3}\right) \\ \rho_{p} & =\text { density particles } & \left(\mathrm{kg} \cdot \mathrm{m}^{-3}\right)\end{array}$

\section{ACKNOWLEDGEMENTS}

We wish to thank Mr. H. Heij for nitrite and nitrate analysis, Drs. M. Smit for assistance in sectioning of the beads, Mr. D. Schoonderbeek for assistance with the image-analysis equipment, Mr. H. Meijer for performing the experiment starvation of cells under oxygen depletion and Dr. M. van Montfort for discussions concerning the interpretations of the results from image analysis.

\section{REFERENCES}

1. Aleem M.I.H., Alexender M. (1958) Cell-free nitrification by Nitrobacter. J Bacteriol 76: 510-514

2. Aleem M.I.H., Alexander M. (1960) Nutrition and physiology of Nitrobacter agilis. Appl Microbiol 8: $80-84$

3. Andrews G. (1988) Effectiveness factors for bioparticles with Monod kinetics. Chem Eng J 37: B31-B37

4. Beettink H.H., Van Der Heijden R.T.J.M., Heijnen J.J. (1990) Maintenance requirements: energy supply from simultaneous endogenous respiration and substrate consumption. FEMS Microb Ecol 73: 203-209

5. Belser L.W. (1979) Population ecology of nitrifying bacteria. Ann Rev Microb 33: 309-333

6. Belser L.W. (1984) Bicarbonate uptake by nitrifiers: effects of growth rate, pH, substrate concentration, and metabolic inhibitors. Appl Environ Microbiol 48: 1100-1104

7. Bird R.B., Stewart W.E., Lightfoot E.N. (1960) Transport phenomena. Wiley International edition, New York, $780 \mathrm{p}$

8. Black G.M. (1986) Immobilized cell physiology. In: Process Engineering Aspects of Immobilized Cell Systems. Eds: C. Webb, G.M. Black, B. Atkinson. The Institution of Chemical Engineers, Warwickshire, pp 75-86

9. Bock E. (1965) Vergleichende Untersuchungen über die Wirkung sichtbaren Lichtes auf Nitrosomonas europaea und Nitrobacter winogradskyi. Arch Microbiol 51: 18-41

10. Boon B., Laudelout H. (1962) Kinetics of nitrite oxidation by Nitrobacter winogradskyi. Biochem 


\section{Oxygen consurnptlon rate of immobllized Nitrobacter}

J 85: $440-447$

11. Bultelaar R.M., Hulst A.C., Tramper J. (1989) Immoblization of biocatalysts in thermogels using the resonance nozzle for rapid drop formation and an organic solvent for gelling. Biotechnol Techn 2: $109-114$

12. Chen K.C., Huang C.T. (1988) Effects of the growth of Trichosporon cataneum in calcium alginate gel beads, upon structure and oxygen transfer characteristics. Enzyme Microb Technol 10: 284-292

13. De Gooljer C.D., Hens H.J.H., Tramper J. (1989) Optimum design for a series of continuous stirred tank reactors containing immobilized biocatalyst beads obeying intrinsic Michaelis-Menten kinetics. Bioprocess Eng 4: 153-158

14. De Gooljer C.D., Wijffels R.H., Tramper J. (1991) Growth and substrate consumption of Nitrobacter agilis cells immobilized in carrageenan: part 1. dynamic modeling. Biotechnol Bioeng 38: 224-231

15. Gay G., Corman A. (1981) Comparative study of the growth of two strains of Nitrobacter in batch and continuous culture Microb Ecol 10: 99-105

16. Gosmann B., Rehm H.J. (1988) Influence of growth behaviour and physiology of alginate-entrapped microorganisms on the oxygen consumption. Appl Microb Biotechnol 29: 554559

17. Gould G.W., Lees H. (1960) The isolation and culture of the nitrifying bacteria Part 1. Nitrobacter. Can J Microbiol 6: 299-307

18. Greenberg A.E., Trussel R.R., Clesceri L.S. (1985) Standard methods for the examination of water and wastewater. 16th ed American Public Health Association, Washington DC, $1268 \mathrm{p}$

19. Gujer W., Boller M. (1989) A mathematical model for rotating biological contactors. In: Proceedings of the Technical Advances in Bioreactors conference, Nice, CFRP-AGHTM, Paris

20. Helder W., De Vries R.T.P. (1983) Estuarine nitrite maxima and nitrifying bacteria (Ems-Dollard estuary). Netherlands J Sea Research 17 (1): 1-18

21. Hennig A. (1969) Fehler der Volumermittlung aus der Flächenrelation in dicken Schnitten (Holmes Effekt). Mikroskopie 25: 25-44

22. Herbert D. (1959) Some principles of continuous culture. In: Recent Progress in Microbiology. Ed. G. Tunevall, Almquist \& Wicksell, Stockholm, p 381-396

23. Hiemstra H., Dijkhuizen L., Harder W. (1983) Diffusion of oxygen in alginate gels related to the kinetics of methanol oxidation by immobilized Hansenula polymorpha cells. Appl Microb Biotechnol 18: 189-196

24. Hulst A.C., Hens H.J.H., Buitelaar R.M., Tramper J. (1989) Determination of the effective diffusion coefficient of oxygen in get materials in relation to gel concentration. Biotechnol Techn 3: $199-204$

25. Hulst A.C., Tramper J., Van 't Riet K., Westerbeek J.M.M. (1985) A new technique for the production of immobilized biocatalyst in large quantities. Biotechnol Bloeng 27: 870-876

26. Keen G.A., Prosser J.I. (1987) Steady state and transient growth of autotrophic nitrlfying bacteria. 
Arch Microbiol 147: 73-79

27. Laane C., Boeren S., Vos K., Veeger C. (1987) Rules for optimization of biocatalysis in organic solvents. Blotechnol Bloeng 30: 81-87

28. Laudelout H., Simonart P.C., Van Droogenbroeck R. (1968) Calorimetric measurement of free energy utilization by Nitrosomonas and Nitrobacter. Arch Microb 63: 256-277

29. Laudelout H., Van Tichelen L. (1960) Kinetics of the nitrite oxidation by Nitrobacter winogradskyi J Bacteriol 79: 39-42

30. Lees H., Simpson J.R. (1957) The biochemistry of nitrifying organisms. Biochem J 65: 297-305

31. Monbouquette H.G., Ollis D.F. (1986) A structural model for immobilized cell kinetics. Ann NY Acad Sc 469: 230-244

32. Müller-Neuglück M., Engel H. (1961) Photoinaktwierung von Nitrobacter winogradskyi Buch Arch Microbiol 39: 130-138

33. O'Kelley J.C., Becker G.E., Nason A. (1970) Characterization of the particulate nitrite oxidase and Its component activities from the chemoautotroph Nitrobacter agilis. Biochim Biophys Acta 4: 393425

34. Painter H.A. (1970) A review of literature on inorganic nitrogen metabolism in microorganisms. Water Res 4: 393-450

35. Peeters T.L., Van Gool A.P., Laudelout H. (1969) Kinetic study of oxygen-limited respiration in nitrifying bacterla. Bacterlol Proc Am Soc Microb, Washington DC, p 141

36. Pirt S.J. (1966) The maintenance energy of bacteria in growing cultures. Proc Royal Soc London 163B: 224-231

37. Ranz W.E., Marshall W.R. (1952) Evaporation from drops, part 2. Chem Eng Progr 48: 173-180

38. Rennie R.J., Schmidt E.L. (1977) Autecological and kinetic analysis of competition between strains of Nitrobacter in soils. Ecol Bull (Stockholm) 25: 431-441

39. Roels J.A. (1983) Energetics and kinetics in biotechnology. Elsevier Biomedical Press, Amsterdam, $330 \mathrm{p}$

40. Salmon P.M. (1989) Mass transport phenomena in reactors containing entrapped cells or bacterial cells. Ph.D. Thesis, Stanford University, Stanford, USA, 348 p

41. Sänger P., Deckwer W.D. (1981) Liquid-solid mass transfer in aerated suspensions. Chem Eng J 22: 179-186

42. Scott C.D., Woodward C.A., Thompson J.E. (1989) Solute diffusion in biocatalyst gel beads containing biocatalysis and other additives. Enzyme Microb Technol 11: 258-263

43. Sharma B., Ahiert R.C. (1977) Nitrification and nitrogen removal. Water Res 11: 897-925

44. Silver W.S. (1961) Studies on nitrite oxidizing microorganisms: I. nitrite oxidation by Nitrobacter. Soil Sc Soc Proc 25: 197-199

45. Stenstrom M.K., Poduska R.A. (1980) The effect of dissolved oxygen concentration on nitrification. Water Res 14: 643-649

46. Stewert P.S., Robertson C.R. (1989) Microbial growth in a fixed volume: studies with entrapped Escherichia coli. Appl Microb Biotechnol 30: 34-40 
47. Tramper J. (1985) Nitrification and denitrification by immobilized bacteria. Third Eur Congr Biotechnol 4, VCH Weinheim, p 363-368

48. Tramper J. (1987) Nitrification and denitrification by immobilized viable cells. In: Enzyme Engineering 8, Eds. A.I. Laskin, K. Mosbach, D. Thomas, L.B. Wingard. Ann N Y Acad Sci 501, New York, p 362-366

49. Tramper J., De Man A.W.A. (1986) Characterization of Nitrobecter agilis immoblized in calcium alginate. Enzyme Microb Techn 8: $472-476$

50. Tramper J., Grootjen D.R.J. (1986) Operating performance of Nitrobacter agilis immobilized in carrageenan. Enzyme Microb Techn 8: 477-480

51. Tramper J., Suwinska-Borowiec G., Klapwijk A. (1985) Characterization of nitrifying bacteria immobilized in calcium alginate. Enzyme Microb Technol 7: 155-160

52. Undenwood E.E. (1972) The stereology of projected images. J Microscopy 95: 25-44

53. Van Droogenbroeck R., Laudelout H. (1967) Phosphate requirements of nitrifying bacteria. Antonie van Leeuwenhoek 33: 287-296

54. Van Ginkel C.G., Tramper J., Luyben K.Ch.A.M., Klapwijk A. (1983) Characterization of Nitrosomonas europaea immobilized in calcium alginate. Enzyme Microb Technol 5: 297-303

55. Van Neorven R.W., Wiffels R.H., Zehnder J.B. (1990) Scanning electron microscopy of immobilized bacteria in gel beads: a comparative study of fixation methods. $J$ Microb Methods 11: 157-168

56. Venkatasubramanian K., Karkare S.B., Vleth W.R. (1983) Chemical engineering analysis of immobilized-cell systems. Appl Blochem Bioeng 4: 311-349

57. Wagner K., Hempel D.C. (1988) Biodegradation by immobilized bacteria in an airlift-loop reactor: Influence of biofilm diffusion limitation: Biotechnol Bioeng 31: 559-566

58. Weibel E.R. (1979) Stereological methods 1, Academic Press, London, 415 p

59. Weibel E.R. (1980) Stereological methods 2, Academic Press, London, $340 \mathrm{p}$

60. Wijtiels R.H., Tramper J. (1989) Performance of growing Nitrosomonas europaea cells immobilized in $\kappa$-carrageenan. Appl Microbiol Biotechnol 32: 108-112

61. Williamson K.J., McCarty P. (1975) Rapid measurement of Monod half-velocity coefficients for bacterial kinetics. Biotechnol Bioeng 17: 915-924

62. Yoshioka T., Saijo Y. (1984) Photoinhibition and recovery of $\mathrm{NH}_{4}{ }^{+}$-oxidizing bacteria and $\mathrm{NO}_{2}$ oxidizing bacteria. J Gen Appl Microbiol 30: 151-166 


\section{INTERMEZZO}

After immobilization the bacteria are distributed homogeneously as single cells over the gel.

Substrate is supplied to the bioreactor which diffuses to the immobilized cells. The bacteria will grow in the gel beads. Growth takes place by cell division and as a consequence clumps of cells are formed: microcolonies.

Micro-colonies were observed with scanning electron miscroscopy. In order to obtain a picture the object is coated with a very thin gold layer. This gold layer allows the relief of the surface to be observed. A beam of electrons is shooted at the object. Secondary electrons are generated out of the gold and these electrons are detected. The relief is being distinguished and the image is obtained, because the intensity of the electrons coming from deeper or higher regions of the surface is different.

Beads were split and micro-colonies on the obtained inside surface could be observed (bar length $10 \mu \mathrm{m}$ ). Bacteria inside the micro-colonies can be distinguished.

The outside surface was also examined (bar length $10 \mu \mathrm{m}$ ). Expansion of colonies resulted in the formation of protrusions. Further expansion of colonies results in eruption of entire colonies from the gel beads. 


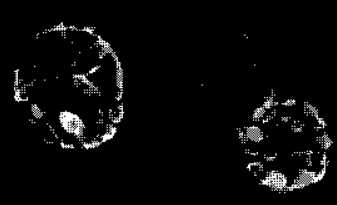

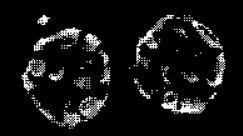

$+2)$

tom

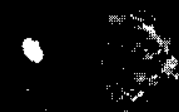

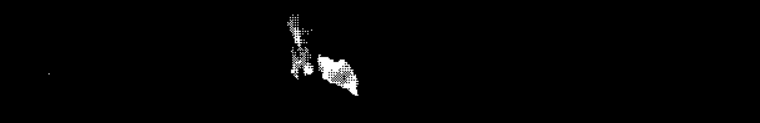

(1)

t 
This chapter has beeri submitted for publication by the authors R.H. Wiffels, M.R. Eekhof, D. de Beer, J.C. van den Heivel and J. Tramper

\section{CHAPTER 5}

\section{PSEUDO-STEADY-STATE OXYGEN- CONCENTRATION PROFILES IN AN AGAR SLAB CONTAINING GROWING NITROBACTER AGILIS}

\section{ABSTRACT}

A dynamic model for growth and substrate consumption of immobilized cells is evaluated by comparing experimental and calculated pseudo-steady-state oxygenconcentration profiles in the support material. For this, Nitrobacter agilis cells were immobilized and cultivated in agar slabs. The system was operated as a continuous submerged-bed reactor. At different growth stadia oxygen-concentration profiles were determined in the slabs with a microsensor. It was shown that simulated and measured profiles agreed very well, both in steady and in pseudo-steady states.

\section{INTRODUCTION}

Nitrogen reduction in waste streams can be accomplished by nitrification and denitrification in biological wastewater-treatment plants. Especially nitrification is a problematic process, because of the low growth rate of the microorganisms involved. 
The capacity of nitrification reactors can be increased by uncoupling the bacterial and the liquid-retention time, e.g. by immobilization of the bacterial cells. Immobilization of bacteria is widely used in wastewater-treatment systems, by taking advantage of the spontaneous attachment of cells. The resulting biofilm processes, however, are poorly understood because of their complexity: biofilms contain many microbial species, substrates are transferred to the organisms by diffusion and subsequently converted, and parts of the biofilm are lost due to erosion and sloughing. Because natural biofilms are not homogeneous, local variations, e.g. in substrate-concentration profiles, disturb observations. To improve the knowledge of bacterial kinetics in biofilms, research was executed with nitrifying pure cultures immobilized by gel entrapment. ${ }^{4.10}$ In this model system the performance of the immobilized cells is not obscured by uncontrolled processes like erosion or sloughing. Additionally, agar slabs are homogeneous, the surface is well defined and it is possible to distribute initially the biomass homogeneously in the gel. In previous studies a dynamic model for cell growth and substrate consumption was developed and experimentally evaluated. Both internal diffusion of substrate in the beads and external diffusion through the surrounding stagnant layer were incorporated. ${ }^{4}$ In a first evaluation the immobilized Nitrobacter agilis cells were cultivated in an air-lift loop reactor with oxygen as the limiting substrate. It was shown that the observed and predicted macroscopic oxygenconsumption rates agreed well for three different liquid-phase oxygen concentrations. ${ }^{10}$

As a further evaluation, pseudo-steady-state oxygen-concentration profiles have been determined with microelectrodes. Most microelectrode studies were done in flow cells. ${ }^{1,2,3,6}$ If gel beads with immobilized cells cultivated in air-lift loop reactors are transferred to a flow cell, however, the resulting oxygen profiles will only be comparable if the flow conditions in both devices are the same. As was shown by de Gooijer et al. ${ }^{4}$, the influence of external mass transfer is an important factor for growth of immobilized cells. Ideally, cultivation and measurement of substrate-concentration profiles should be performed in the same reactor under the same conditions. Therefore, cells were immobilized in a flat agar plate on the bottom of a stirred reactor, enabling a large number of profile measurements in time at a fixed radial distance from the stirrer without influencing the cultivation conditions. 


\section{MATERIALS AND METHODS}

\section{Organism, culture conditions and immobilization procedure}

Nitrobacter agilis was cultivated in a continuous culture at a dilution rate of $2.8 \mathrm{x}$ $10^{-6} \mathrm{~s}^{-1}$. The growth medium has been described before. ${ }^{10}$ Effluent was collected for $2-3$ days and cells were harvested by centrifugation during $20 \mathrm{~min}$ at $16,300 \mathrm{~g}$. The concentrated cell suspension was mixed with an agar solution at $39{ }^{\circ} \mathrm{C}$ in such a way

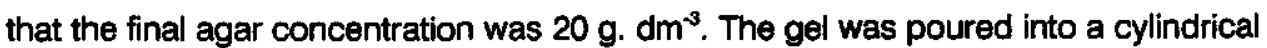
vessel and after cooling a gel layer was formed on the bottom of the vessel.

\section{Immobilized-cell reactor}

The vessel with the agar plate was placed in a Faraday cage and used as a submerged-bed reactor as is shown in Fig. 1 . The reactor was continuously fed at a high dilution rate $\left(2 \times 10^{-4} \mathrm{~s}^{-1}\right)$ to ensure that during the entire experiment nutrients were available in excess and oxygen was the growth-limiting substrate. The liquid was mixed with a turbine stirrer (Applikon 1012) at a speed of $150 \mathrm{rpm}$ situated $2.5 \mathrm{~cm}$ above the agar plate. The temperature was maintained at $30^{\circ} \mathrm{C}$. Oxygen was supplied by a small air sparger; the liquid phase was air saturated during the entire experiment.

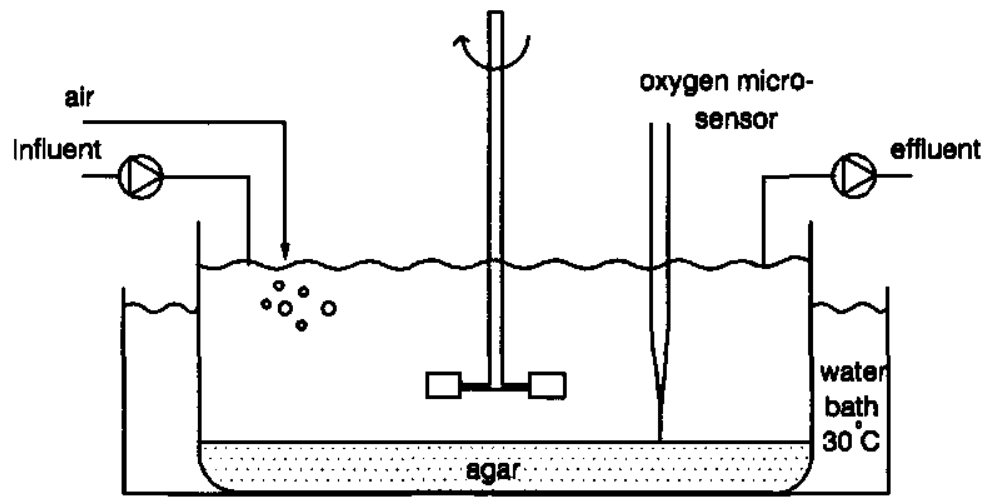

Fig. 1: Experimental set up for determination of oxygen-concentration profiles in a submerged agar-gel siab. 
The medium composition was as given before ${ }^{10}$, except that sodium salts were used instead of potassium salts.

Two experiments were executed; in a vessel with a diameter of 12.7 and $17.4 \mathrm{~cm}$, respectively. The corresponding thickness of the agar layer was 2 and $1.5 \mathrm{~cm}$, respectively.

The thickness of the stagnant layer will vary over the plate. For this reason, the variation of the thickness of the stagnant layer as a function of radial distance from the stirrer was determined, by measuring oxygen-concentration profiles as a function of distance from the turbine stirrer. For this experiment immobilized yeast cells were used, because it is possible to immobilized them at a high concentration. The medium consisted of an acetate buffer $\left(0.02 \mathrm{~mol}^{\mathrm{dm}} \mathrm{dm}^{-3}, \mathrm{pH} 7\right)$.

\section{Microelectrode}

Oxygen-concentration profiles were measured with an oxygen microsensor. Electrodes with internal reference and a tip diameter of $10 \mu \mathrm{m}$ were prepared as described before. ${ }^{3,9}$

\section{Model}

The model was described previously by De Gooijer et al. ${ }^{4}$ Pseudo-steady states with respect to the substrate-concentration profile over the beads were assumed. Within one time step a differential mass balance over the plate in which simultaneous diffusion and consumption occurs was solved. External mass transfer was calculated by the film theory. The macroscopic consumption rate of cells was calculated according to Monod kinetics in which maintenance

\section{Table I: Model-input parameters}

effective diffusion coefficient

$D_{a, g} \quad\left(m^{2} . s^{-1}\right) \quad 2.35 \times 10^{-9}$

liquid/solid mass-transfer coefficient

$k_{i, s} \quad\left(\mathrm{~m}^{-s^{-1}}\right) \quad 5.5 \times 10^{-5}$

kinetic parameters

\begin{tabular}{|c|c|c|}
\hline $\begin{array}{l}\mu_{\text {max }} \\
K_{s} \\
Y_{m}\end{array}$ & $\begin{array}{l}\left(\mathrm{s}^{-1}\right) \\
\left(\mathrm{mol} \cdot \mathrm{m}^{-3}\right) \\
\left(\mathrm{kg} \cdot \mathrm{mol}^{-1}\right) \\
\left(\mathrm{mol} \cdot \mathrm{kg}^{-1} \cdot \mathrm{s}^{-1}\right)\end{array}$ & $\begin{array}{l}1.0 \times 10^{-5} \\
0.017 \\
1.16 \times 10^{-3} \\
1.1 \times 10^{-3}\end{array}$ \\
\hline
\end{tabular}

biomass concentrations

$\begin{array}{lll}X_{0}(\exp .1) & \left(\mathrm{kg} \cdot \mathrm{m}^{-3}\right) & 7 \times 10^{-3} \\ X_{0}(\exp .2) & \left(\mathrm{kg} \cdot \mathrm{m}^{-3}\right) & 6 \times 10^{-3} \\ X_{\text {max }} & \left(\mathrm{kg} \cdot \mathrm{m}^{-3}\right) & 11\end{array}$


requirements were taken into account. The set of equations was solved numerically using a second-order Runge-Kutta algorithm. The resulting substrate-concentration profile was used to calculate the biomass-concentration profile. The local biomass concentration was restricted to a maximum as a straightforward application of the differential equations would lead to infinitely high biomass concentrations near the surface of the bead.

Model input parameters (Table 1) were the same as in previous work ${ }^{10}$, except for the diffusion coefficient in the gel, the initial biomass concentration and the external mass-transfer coefficient. For the effective diffusion coefficient in agar the value found by Hulst $\theta t a{ }^{7}$ was used. The initial biomass concentration was measured by means of colony counts of microscopic sections. It was assumed that each cell formed a separate colony as result of growth. After some time colonies could be observed and counted. Agar samples were taken after 13 and 21 days of cultivation in the first experiment and after 15 and 23 days in the second experiment. Agar cylinders were cut out of the plate and $3 \mu \mathrm{m}$ sections were cut from the cylinder with an ultramicrotome as described before. ${ }^{10}$ The remaining hole was filled up with fresh agar. The numerical concentration obtained was converted to a mass density by a conversion factor of $10^{-10} \mathrm{mg} /$ cell. $^{8}$

\section{RESULTS AND DISCUSSION}

Variation in the thickness of the stagnant layer as a function of the radial distance from the stirrer was evaluated with immobilized yeast cells. Profiles were determined at the boarders of a strip of agar with a width of $1 \mathrm{~cm}$, concentrically situated around the stirrer. It was shown that at $150 \mathrm{rpm}$ at the two boarders exactly the same profiles were obtained (Fig. 2), which means that the hydrodynamic conditions above this strip are the same. For the experiment with immobilized Nitrobacter agilis cells, the same conditions were chosen and profiles were measured at the same location. As both growth and measurements of the profiles were done under these conditions the external mass-transfer coefficient can be assumed to be constant during the entire experiment. 
oxygen concentration (mM)

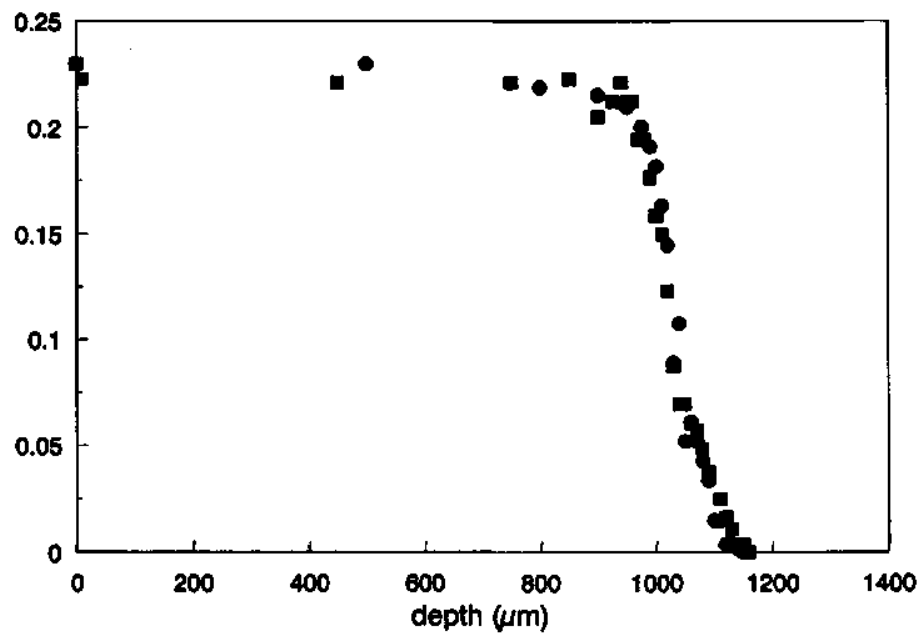

Fig. 2: Oxygen-concentration profiles of immobilized yeast cells in an agar slab at the borders ( inside, outside) of a strip, concentrically situated around the stirrer.

From colony counts in agar samples it could be derived that the initial biomass concentration was $7 \times 10^{-3} \mathrm{~kg} . \mathrm{m}^{-3}$ and $6 \times 10^{-3} \mathrm{~kg}^{-3} \mathrm{~m}^{-3}$ for the two experiments, respectively.

In the two separate experiments transient-state oxygen-concentration profiles of Nitrobacter agilis were measured. It appeared to be difficult to determine the exact position of the gel surface. In the case of particles this is done by rectangular observation of the point where the electrode penetrates the gel or biofilm. ${ }^{3.5}$ In the case of a gel plate, however, observation is done in a birds-eye perspective and depths are difficult to estimate. As is shown in Fig. 2, profiles tend to be very steep as within a depth of $20 \mu \mathrm{m}$ the oxygen concentration decreases $0.1 \mathrm{mM}$. A spatial resolution of $20 \mu \mathrm{m}$ in the determination of the location of the surface was impossible to obtain. For this reason other approaches were used. Based on the approximated position of the gel surface and the assumption that the thickness of the stagnant liquid film is constant, the position of the boundary of the liquid film can be determined according to Hooijmans et $a l .^{6}$ They determined the thickness of the stagnant layer by means of linear regression, using five data points. In our case, the thickness obtained was dependent on the number of data points that were included in the regression 
oxygen concentration (mM)

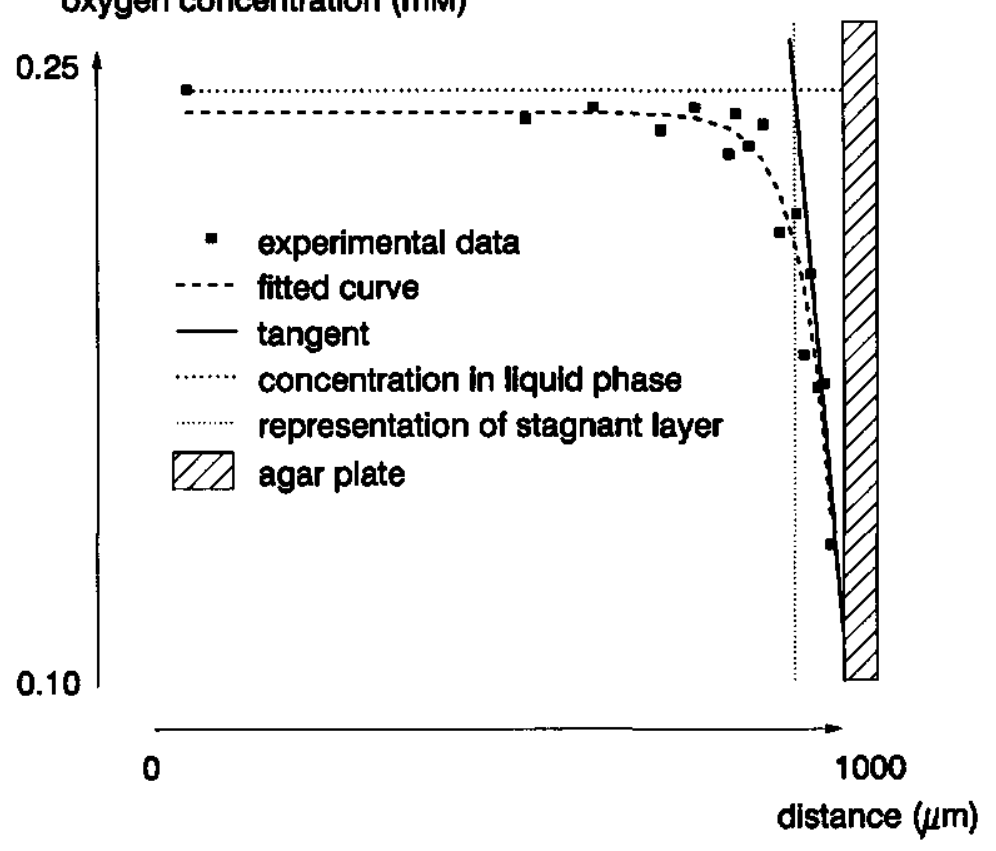

Fig. 3: Oxygen-concentration profile in the liquid phase.

analysis. This can be explained by the fact that the film theory, in which it is assumed that the concentration is linear with distance, used is a simplification of reality. In reality it is a non-linear function as is shown in Fig. 3. For this reason a non-linear function was fitted, the tangent was determined and the intersection of this tangent and the line representing the concentration of the bulk liquid phase determined the film thickness as is shown in Fig. 3. A disadvantage of this method was, that fluctuations in concentration in the liquid film occurred, resulting in variations in the thickness of the film layer found. We determined the location of the gel surface by fitting the masstransfer coefficient with the simulation programme of $\mathrm{De}$ Gooijer et al. ${ }^{4}$ to the experimental data of the profile after 12 days of cultivation. The measured profile was matched with the calculated profile by translation of the origin. At a mass-transfer coefficient of $5.5 \times 10^{-5} \mathrm{~m}^{-1} \mathrm{~s}^{-1}$ experimental and calculated profiles were in close agreement. For the other days, it was assumed that the mass-transfer coefficient was the same. 
Evaluation of the pseudo-steady-state profiles was done in a continuously operated submerged agar slab. The nitrite concentration in the influent was $15 \mathrm{~mol} . \mathrm{m}^{3}$. At the dilution rate applied the nitrite concentration in the effluent was never lower than 13 mol. $\mathrm{m}^{-3}$, which means that oxygen was the limiting substrate during the whole experiment. ${ }^{410}$ Experimentally obtained and simulated transient-state oxygenconcentration profiles after $5,6,7,10,11,12,13,14,18$ and 21 days of cultivation are shown in Fig. 4. The first days after immobilization the oxygen-concentration profile is flat, while the gradients increase as growth proceeds. After about 13 days a steadystate situation has been reached as judged from the concentration profiles. The profiles show clearly that the gradient over the stagnant liquid layer was considerable.

At day 13 and 18 the measured oxygen profile over the stagnant layer is somewhat lower than the calculated values. Additionally, these measurements show high scattering of the signal. Generally experimental profiles in the steady state situation are in closer agreement with the model predictions than in the start-up phase. On the whole, however, simulated and experimental results agree very well. In the second experiment similar results were obtained (results not shown).

\section{CONCLUSIONS}

It has been shown that microelectrode studies can be a valuable method to evaluatemathematical modelsthat describepseudo-steady-state oxygen-concentration profiles over immobilized-cell slabs.

A drawback of the method used is the resolution in determination of the position of the microelectrode. As profiles tend to be very steep in a 'full-grown' slab, the accuracy of determination of the position is a limiting factor. Nevertheless, it was shown that model and experimental data were in excellent agreement for Nitrobacter agilis immobilized in an agar plate. 
Oxygen-concentration profles in an agar slab
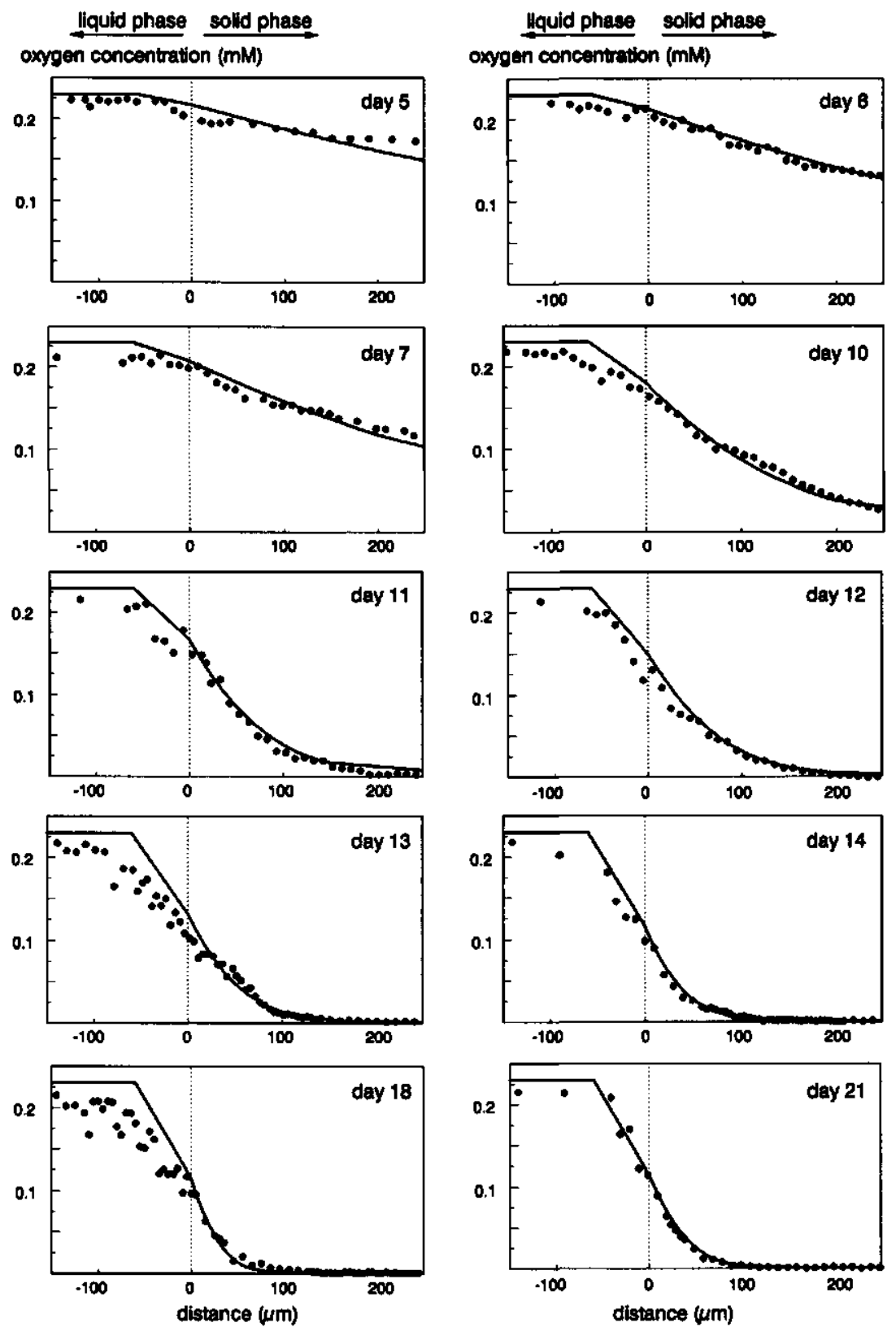

Fig. 4: Experimental and simulated transient-state oxygen-concentration profiles in an agar slab with immobilized Nitrobacter agilis after $5,6,7,10,11,12,13,14,18$ and 21 days of cultivation. 


\section{LITERATURE}

1 De Beer D., Van Den Heuvel J.C. (1988) Gradients in immobilized blological systems. Analytica Chimica Acta 213: 259-265

2 De Beer D., Van Den Heuvel J.C., Sweerts J.P.R.A. (1990) Microelectrode studies in immobilized biological systems. In: Physiology of Immobilized Cells. Eds.: J.A.M. De Bont, J. Visser, B. Mattiasson, J. Tramper. Elsevier Science Publishers B.V., Amsterdam, p 613-624

3 De Beer D. Van Den Heuvel J.C., Ottengrat S.P.P. (1993) Microelectrode measurements of the activity distribution in nitrffying bacterial aggregates. Appl Environm Microbiol 59: 573-579

4 De Gooljer C.D., Wijfels R.H., Tramper J. (1991) Growth and substrate consumption of Nitrobacter agills cells immobilized in carrageenan. Part I: dynamic modeling. Biotechnol Bioeng 38: 224-231

5 Hooijmans C.M., Ras C., Luyben K.Ch.A.M. (1990) Determination of oxygen profiles in biocatalyst particles by means of a combined polarographic oxygen microsensor. Enzyme Microb Technol 12 178-183

6 Hooijmans C.M., Geraats S.G.M., Potters J.J.M., Luyben K.Ch.A.M. (1990) Experimental determination of mass transfer boundary layer around a spherical biocatalyst particle. Chem Eng J 44: B41-B46

7 Hulst A.C., Hens H.J.H., Bultelaar R.M., Tramper J. (1989) Determination of the effective diffusion coefficient of oxygen in get materials in relation to gel concentration. Blotechnol Techn 3: $199-204$

8 Lees H., SImpson J.R. (1957) The biochemistry of nitrifying organisms 5. nitrite oxldation by Nitrobacter. Biochem J 65: 297-305

9 Revsbech M.P., Ward D.M. (1980) Oxygen microelectrode that is insensitive to medium chemical composition: use in an acid microbial mat dominated by Cyanidlum caldarlum. Appl Environm Microblol 45: 755-759

10 Wijtfels R.H., De Gooljer C.D., Kortekaas S., Tramper J. (1991) Growth and substrate consumption of Nitrobacter agilis cells immobilized in carrageenan. Part II: model evaluation. Biotechnol Bioeng 38: 232-240 
INTERMEZZO 
In the nitrification process ammonia is converted with oxygen to nitrate. The rate with which the micro-organisms convert the ammonia to nitrate depends on the concentration of ammonia or oxygen. Generally this activity of the bacteria is higher when the concentration of one of these compounds is higher. In our experiments oxygen was always the ratelimiting substrate.

Oxygen is supplied to the bacteria by bubbling air in the reactor. Schematically, the process can be represented as follows. Oxygen will be transferred from the air bubbles to the liquid phase. It is then transferred from the liquid phase to the gel beads, through the gel matrix and into the colonies. Finally a reaction will occur in the colonies.

We developed equations for all of these steps and combined those equations to an overall model. With that model we were able to calculate the rate of the process. Experiments were used to verify if our model contained the correct components. 


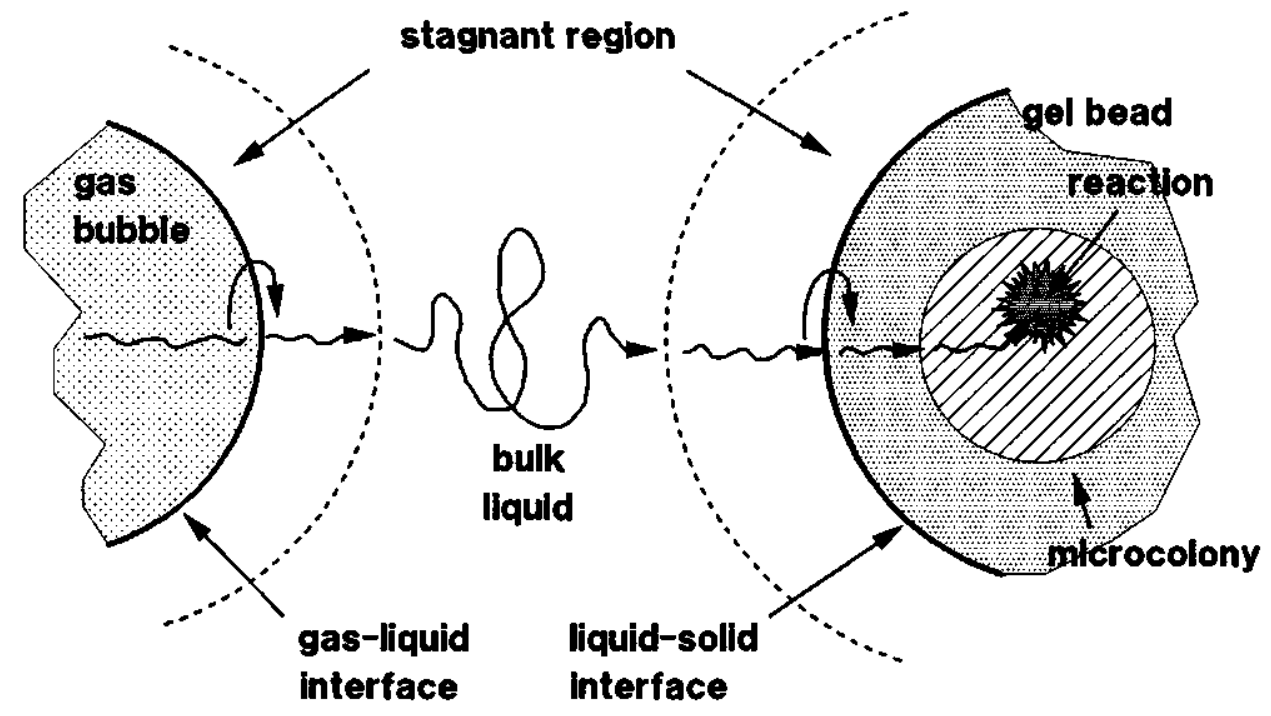


This chapter has been submitted for publication by the authors R.H. Wijffels, C.D. de Gooljer, A.W. Schepers, E.E. Beuling, L.F. Mallée and J. Tramper

\title{
CHAPTER 6
}

\section{DYNAMIC MODELLING OF IMMOBILIZED \\ NITROSOMONAS EUROPAEA: IMPLEMENTATION OF \\ DIFFUSION LIMITATION OVER EXPANDING MICRO-COLONIES}

\begin{abstract}
A dynamic model describing growth and substrate consumption of immobilized bacteria has been successfully evaluated for Nitrobacter agilis . Further evaluation of the model for immobilized Nitrosomonas europaea resulted in predictions of consumption rates, which were higher than the experimentally obtained rates. It was suspected that this overestimation was caused by effects of diffusion limitation over micro-colonies. For this reason diffusion limitation over micro-colonies has now been integrated in the model: the colony-expansion model. Growth is represented by expansion of colonies. Colonies breaking through the gel surface cause release of bacteria into the surrounding medium. Two options were considered for this release: either growth resulting in continuous leakage of single bacteria or eruption of entire colonies at once. In the latter case both macroscopic consumption rates and transientstate biomass-concentration profiles are described satisfactorily by the model. Results
\end{abstract}


of the previous experiments with Nitrobacter agilis can also be described satisfactorily by the model as well.

\section{INTRODUCTION}

Many papers are dedicated to modelling of simultaneous reaction and diffusion in immobilized-cell reactors. In the majority of these models, however, i) no growth is considered, ii) a homogeneous biomass distribution is assumed (over the entire bead or film), iii) only the steady state is treated, and iv) external mass transfer has not been included. Steady-state models for growing cells can be quite satisfactory for design purposes, but fail to describe the start-up phase and the response to changing conditions in the reactor.

Substrate gradients result in heterogeneous distributions of viable cells due to growth and death of cells., ${ }^{8,27,42}$ Only for very small particles, non-uniform cell growth can be prevented. ${ }^{6}$ For these reasons dynamic models have been developed describing simultaneous substrate consumption and growth., ${ }^{8,14,18,27}$

Evaluation of the model of De Gooijer et al. ${ }^{\mathrm{B}}$ with immobilized Nitrobacter agilis showed that predicted oxygen-consumption rates agree well for three different bulkphase oxygen concentrations..$^{42} \mathrm{~A}$ discrepancy, however, was found in the biomassconcentration profiles. ${ }^{8}$ In the model, in the outer shells of the gel bead a constant maximum biomass concentration was defined, while experimentally a peak was observed. This was explained by the growth of biomass in micro-colonies.

Application of the model of De Gooijer et al. ${ }^{8}$ to growth of Nitrosomonas europaea, did not only show differences in biomass concentration profiles, but in macroscopic consumption rates as well. Overestimations were suspected to be due to diffusion limitation over the micro-colonies. For this reason diffusion limitation over microcolonies has now been included in the model. Consequently, model calculations and experimental results of macroscopic consumption rates and biomass-concentration profiles indeed agree better. 


\section{GROWTH MODELS}

Pseudo-homogeneous growth model

The pseudo-homogeneous growth model was described previously by De Goojer et al. ${ }^{8}$ Growth of biomass and consumption of substrate were treated separately because the time scale for growth is several orders of magnitude larger than for substrate consumption. A pseudo-steady state with respect to the substrateconcentration profiles over the beads was assumed in one time step. Each time step a differential mass balance over a bead in which simultaneous diffusion and consumption is incorporated was solved. External mass transfer was calculated by the film theory. The macroscopic consumption rate of cells was calculated according to Monod kinetics in which maintenance requirements were taken into account. ${ }^{2}$ The set of equations was solved numerically using a second-order Runge-Kutta algorithm. The resulting substrate-concentration profile was used to calculate the biomassconcentration profile. The local biomass concentration was restricted to a maximum as a straightforward application of the differential equations would lead to infinitely high biomass concentrations near the surface of the bead.

\section{Colony-expansion model}

After inoculation, the concentration of cells is usually low and the cells are spatially uniformly distributed in the beads. Growth results in the formation of expanding microcolonies. Due to transport limitation, colonies near the surface of the support material grow faster than the colonies near the centre. Expanding colonies near the surface of the gel beads will eventually touch the gel surface and biomass is released. ${ }^{33}$ In our case we assume that colonies need to build up pressure to break through the gel surface. It was arbitrarily assumed that release occurs as soon as $1 / 3$ of the volume of the micro-colony protrudes. Furthermore, two mechanisms of biomass release are considered: either growth resulting in continuous leakage of single bacteria or eruption of entire colonies at once.

We did not incorporate a maximum biomass concentration in the colony-expansion model. Expanding colonies will grow until single-cell leakage or eruption occurs, or the growth rate will be restricted by diffusion limitation over the micro-colonies. The 
effectiveness factor of large micro-colonies will eventually be so low that the rate of expansion becomes negligible.

Substrate-concentration profiles over gel beads were calculated in a similar way as in the pseudo-homogeneous growth model, except for the fact that an effectiveness factor, $\eta(r)_{c}$, was inserted in order to account for diffusion limitation inside the microcolonies:

$$
D_{a, s}\left(\frac{1}{r^{2}} \frac{d}{d r}\left(r^{2} \frac{d S}{d r}\right)\right)=\eta\left(r_{c} r_{s}\right.
$$

with the boundary conditions:

$$
\begin{array}{lll}
S-S_{s} & \text { at } & r=r_{b} \\
\frac{d S}{d r}-0 & \text { at } & r=0 \text { or } r=r_{f}
\end{array}
$$

Calculation of the substrate-consumption rate and combination with external masstransfer effects was the same as in the pseudo-homogeneous growth model. Equation 1 was solved by dividing the gel bead in 500 shells. In each shell the substrate concentration was calculated with a second-order Runge-Kutta algorithm. The colony effectiveness factor was calculated in all shells based on local substrate concentration and colony radius. In every shell the specific growth rate and the increase in colony radius was calculated.

For calculation of $\eta(r)_{c}$ it was assumed, that the colonies remain spherical and that the biomass concentration inside the colonies $\left(X_{c}\right)$ is constant, both in time and space. The substrate concentration over the colony/gel interface is not constant with position. For simplicity, however, we assumed the substrate concentration to be the same all over the surface. For this concentration, the concentration in the shell where the centre of the colony is situated was used.

The effectiveness factor is defined as:

$$
\eta(r)_{0}=\frac{r_{s, s}^{c}}{r_{s i}^{0}}
$$


The actual substrate-consumption rate, $r_{s, a}{ }^{c}$, was calculated by using differential mass balances over the colonies where simultaneous diffusion and consumption occurs:

$$
D_{a, c}\left(\frac{1}{\rho^{2}} \frac{d}{d \rho}\left(\rho^{2} \frac{d S}{d \rho}\right)\right)-r_{s, a}^{c}
$$

with the boundary conditions:

$$
\begin{aligned}
& s=S_{1} \quad \text { at } \quad \rho=\rho_{c} \\
& \frac{d S}{d \rho}=0 \quad \text { at } \quad \rho=0 \text { or } \rho-\rho_{f}
\end{aligned}
$$

The theoretical substrate-consumption rate, $r_{s, t}{ }^{c}$, is calculated according to Beeftink et al. ${ }^{2}$ :

$$
r_{s, t}^{c}-\left(\frac{\mu_{\max }}{Y_{x s}}+m\right) X_{0}\left(\frac{S_{i}}{K_{s}+S_{i}}\right)
$$

The dimensionless form of equation 3 was solved numerically by using the fourthorder Runge-Kutta method.

As indicated, growth is assumed to take place by expansion of colonies. Expansion of colonies is calculated by:

$$
\rho_{G(t)}^{r}-\rho_{G(t)}^{r} e^{\left(\frac{1}{3}\left(\eta(n) \frac{\mu_{\text {max }} S}{K_{s}+S}-m Y_{x s}\left(1-\frac{\eta()_{0} s}{K_{s}+S}\right)\right) \Delta t\right)}
$$

making the radii of the colonies dependent on the radial position of the colony in the gel sphere. From the radius distribution a local volume fraction can be calculated and from that and the colony density $\left(\rho_{x}\right)$ a biomass concentration profile. ${ }^{9,30}$

The colony density $\left(\rho_{x}\right)$ can be obtained by multiplication of $X_{\text {max }}$ by the fraction of the testline that crossed the colonies. In case of Nitrosomonas the resulting density is $71 \mathrm{~kg} \cdot \mathrm{m}^{-3}$ and in the case of Nitrobacter $46 \mathrm{~kg} . \mathrm{m}^{-3}$. 


\section{MATERIALS AND METHODS}

\section{Organism and culture conditions}

Nitrosomonas europaea (ATCC 19718) was cultivated in a $2.8 \mathrm{dm}^{3}$ continuous culture at a dilution rate of $3.47 \times 10^{-6} \mathrm{~s}^{-1}$. The composition of the medium was based on studies on nutrient requirements. ${ }^{3.10,25.26,31,36,37,38}$ The medium contained per $\mathrm{m}^{3}$ of demineralized water: $19.0 \mathrm{~mol}\left(\mathrm{NH}_{4}\right)_{2} \mathrm{SO}_{4} ; 0.21 \mathrm{~mol} \mathrm{MgSO}_{4} ; 5 \mathrm{~mol} \mathrm{NaH} \mathrm{PO}_{4} ; 5 \mathrm{~mol}$ $\mathrm{Na}_{2} \mathrm{HPO}_{4} ; 5 \mathrm{mmol} \mathrm{CaCl} ; 9$ mmol FeSO $\mathrm{ma}_{4} 0.5 \mathrm{mmol} \mathrm{CuSO}_{4}$. The $\mathrm{pH}$ was controlled to 7.4 with $7 \mathrm{M} \mathrm{NaHCO}_{3}$.

\section{Immobilization procedure}

The effluent of the continuous culture was collected during 3 days in an ice-cooled vessel. The cell suspension was centrifuged during 10 minutes at $16,300 \mathrm{~g}$ and $5{ }^{\circ} \mathrm{C}$ and washed with demineralized water.

A $3 \% \kappa$-carrageenan solution (Genugel X0828, A/S Kobenhavns Pektinfabrik, DK Lille Skensved) was mixed gently with the washed suspension such that a $2.6 \%$ carrageenan solution was obtained. The carrageenan solution and the cell suspension were kept at $35^{\circ} \mathrm{C}$.

Immobilization was done with a resonance nozzle at $35{ }^{\circ} \mathrm{C}$ as described previously. ${ }^{42}$

The average bead diameter was $1.85 \mathrm{~mm}$ in the experiment with a liquid-phase oxygen concentration of $0.08 \mathrm{~mol} . \mathrm{m}^{-3}$ and $2.0 \mathrm{~mm}$ in the other experiments. The initial biomass concentration in the beads was $3.45 \times 10^{-3} \mathrm{~kg} . \mathrm{m}^{-3}$.

\section{Immobilized-cell cultivation}

Immobilized cells were cultivated in continuous-flow air-lift loop reactors with a volume of $3.40 \mathrm{dm}^{3}$. The reactors were coupled to a Programmable Logic Controller (PLC Melsec-G, Mitsubishi G62P) which controlled the oxygen concentration in the reactors at constant mass-flow rates by mixing nitrogen gas and air or air and pure oxygen as was described before. ${ }^{42}$ The superficial gas-flow rate was $1.76 \times 10^{-3} \mathrm{~m} . ~^{-1}$. in three experiments, the bulk oxygen concentration was kept at $0.04,0.08$ and 0.12 
mol. $\mathrm{m}^{-3}$, respectively. The influent ammonia concentration was adjusted daily to keep the reactor concentration higher than $10 \mathrm{~mol} . \mathrm{m}^{-3}$. In this way oxygen was kept the limiting substrate.

The medium contained per $\mathrm{m}^{3}$ of demineralized water: a variable amount of $\mathrm{NH}_{4} \mathrm{Cl}$; $0.21 \mathrm{~mol} \mathrm{MgSO}_{4} ; 6.32 \mathrm{~mol} \mathrm{KH}_{2} \mathrm{PO}_{4} ; 6.02 \mathrm{~mol} \mathrm{~K}_{2} \mathrm{HPO}_{4} ; 5 \mathrm{mmol} \mathrm{CaCl}_{2} ; 9 \mathrm{mmol} \mathrm{FeSO}$ and $0.5 \mathrm{mmol} \mathrm{CuSO}_{4}$. The $\mathrm{pH}$ was controlled to 7.4 with $7 \mathrm{M} \mathrm{KHCO}_{3}$. The dilution rate based on the liquid-phase volume was $3.8 \times 10^{-5} \mathrm{~s}^{-1}$ and the reactor gel load $15 \%$ (v/v). Cultivation was carried out at $30^{\circ} \mathrm{C}$ in the dark to prevent effects of light inhibition. . $^{5,17,44}$

\section{Oxygen-consumption rate}

Ammonia oxidation by Nitrosomonas requires stoichiometric amounts of oxygen.' Thus to estimate the oxygen-consumption rate, the nitrite-production rate per amount of gel was determined regularly.

Ammonia and nitrite concentrations in influent and effluent were determined using a continuous-flow analysis system (Skalar Auto Analyser). ${ }^{13}$ For nitrate analysis the samples first passed through a copper-coated cadmium column in order to reduce the nitrate to nitrite. By addition of $\alpha$-naphtylamide in acid medium, the nitrite forms a red diazo compound, that was measured at $550 \mathrm{~nm}$. Ammonia forms a green coloured complex with salicylate that was measured at $660 \mathrm{~nm}$.

\section{Biomass concentration}

Overall viable-biomass estimates were made by activity assays in a biological oxygen monitor as described before. ${ }^{39}$ In a reaction cuvette 100 beads and $3.9 \mathrm{~cm}^{3}$ potassium phosphate buffer $\left(75 \mathrm{mmol} . \mathrm{dm}^{-3}, \mathrm{pH} 7.4\right)$ were suspended and saturated with air. If the activity exceeded $0.002 \mathrm{~mol} . \mathrm{m}^{-3} \mathrm{gel}$. $\mathrm{s}^{-1}$, pure oxygen was used to prevent mass-transfer limitations. Through a small opening $100 \mu \mathrm{ll} \mathrm{M} \mathrm{NH}_{4} \mathrm{Cl}$ was injected. The decrease in oxygen concentration at $30^{\circ} \mathrm{C}$ was recorded.

The activity per amount of gel was converted to a biomass dry-weight concentration by dividing by the specific activity. The specific activity of Nitrosomonas europaea (0.01 mol. $\mathrm{kg}^{-1} . \mathrm{s}^{-1}$ ) was calculated from the values of $\mu_{\max }$ and $Y_{x s}$. 
Determination of biomass-concentration profiles

Transient-state biomass-concentration profiles were determined in the beads cultivated at a liquid phase oxygen concentration of $0.12 \mathrm{~mol}^{-3}$. Samples of the beads were used for image analysis as described before. ${ }^{42}$ Fixation prior to sectioning was done in a single step. In this fixation step a $2 \%(w / v)$ solution of formaldehyde and $2.5 \%(\mathrm{w} / \mathrm{v})$ solution of glutaraldehyde in sodium-cacodylate buffer $(\mathrm{pH} \mathrm{7.4,} 0.1$ $M \mathrm{KCl}$ ) was used. Image analysis was executed on sections through the centre of the beads by sectioning with an ultramicrotome. Sectioning was executed on a LKB 8800 Ultramicrotome III with a glass knife. Sections with a thickness of $2 \mu \mathrm{m}$ were stained with toluidine blue to improve the contrast between the gel and the colonies. The samples were observed at a magnitude of 13.2 with a light microscope and photographs were made with a Kodak Technical Pan film 2415 at 50 ASA. The prints (final magnification 90x) were used for image analysis with a Quantimet 970 (Cambridge Instruments). The Quantimet 970 analyses a field of $800 \times 625$ pixels. Pixels were calibrated to absolute sizes. The width of one pixel was 1.250 or $1.471 \mu \mathrm{m}$. By image analysis the coordinates of the centres of the colonies were determined in relation to the surface of the bead. Also the radii of the colonies were determined. For determination of the volumetric fraction of colonies the beads were divided into fictive shells by test lines. Results were corrected for overestimations as described before. ${ }^{42}$

Starvation under oxygen depletion

For determination of maintenance energy Nitrosomonas europaea was cultivated batch wise in a $1 \mathrm{dm}^{3}$ stirred fermenter. The medium used was the same as in the continuous-flow experiments for immobilized cells. The initial ammonia concentration was $75 \mathrm{mM}$. Due to aeration growth of cells occurred. As soon as the ammonia concentration was reduced to $25 \mathrm{mM}$, nitrogen gas was sparged instead of air. The decrease in activity was taken as a measure for the specific biomass-degradation rate, as can be obtained directly from the relation of Herbert ${ }^{15}$ when substrate concentration is zero:

$$
\ln \frac{X_{t}}{X_{0}}=-m Y_{x s} t
$$


Data for molar substrate yield were obtained from the literature.

Activity was determined as described before, except that it was directly measured in the culture medium.

pH profile

Nitrosomonas europaea was immobilized in carrageenan-gel beads of $3 \mathrm{~mm}$ in diameter. The celis were cultivated in a continuous-flow reactor in the same medium as used for the air-lift experiments at an oxygen concentration of $0.12 \mathrm{~mol} . \mathrm{m}^{3}$. After cultivation, beads were mounted on a needle in a continuous-flow chamber with airsaturated growth medium. Profiles were measured with a $\mathrm{pH}$-microsensor with a tip diameter of $1 \mu \mathrm{m}$ as was described by De Beer et al. ${ }^{7}$

\section{RESULTS AND DISCUSSION}

\section{Input parameters}

All input parameters used in the dynamic mathematical model were obtained from the literature or determined in separate experiments. The liquid/solid mass-transfer coefficient $\left(k_{1,8}\right)$ was directly obtained from our previously reported experiments. ${ }^{42}$

Effective diffusion coefficient $\left(D_{e, g}\right)$

The effective diffusion coefficient for oxygen in $x$-carrageenan beads is $2.1 \times 10^{-9}$ $\mathrm{m}^{2} . \mathrm{s}^{-1.43}$ The effective diffusion coefficient is affected by the concentration of biomass in the support material. For the use of the model of De Gooijer et al. ${ }^{8}$ a biomassconcentration-dependent diffusion coefficient was used. The effective diffusion coefficient will be zero if all pores in the gel are completely filled by bacterial cells, with no intercellular space left. At the gel concentration used, the available pore volume will be at least $95 \%$ of the total gel volume and the pores will be completely filled if the biomass concentration is about $950 \mathrm{~kg} . \mathrm{m}^{-3}$. This value was defined as the maximum physically attainable biomass concentration $X_{p, \text { mer }}$

In the case of the colony-expansion model two different effective diffusion 
coefficients were used, one for the gel material $\left(D_{e, g}\right)$ with a value of $2.1 \times 10^{-9} \mathrm{~m}^{2} . \mathrm{s}^{-1}$ and one for the colonies $\left(D_{e, c}\right)$. Packing of cells is very dense for cells that grow within fixed volumes. ${ }^{33,40}$ Sometimes even mosaic like structures were formed, indicating that free space between cells is filled up due to build up of pressure. ${ }^{10,20,35}$ It has been shown that the effective diffusion coefficient is between 20 and $30 \%$ of the value in media. ${ }^{18,24.41}$ In our case it was assumed that $D_{\theta, c}$ is $25 \%$ of $D_{e, g}$

Maximum specific growth rate $\left(\mu_{\max }\right)$

Values for maximum specific growth rates were obtained from literature. Reported data range from $1.19 \times 10^{-5}$ to $1.75 \times 10^{-5} \mathrm{~s}^{-1.3,4,10,12,25,32,37}$ In our experiments $\mu_{\max }$ was taken to be $1.52 \mathrm{x}$ $10^{-5} \mathrm{~s}^{-1}$, which is the average of the reported values (Table I).

\section{Monod constant $\left(K_{s}\right)$}

Though there are few data, there is a general range of $K_{s}$ values $(0.0078-0.016$ mol. $\mathrm{m}^{-3}$ ) for oxygen of Nitrosomonas europaea. ${ }^{10,22,25,28}$ An average $K_{s}$-value of $0.011 \mathrm{~mol}^{-\mathrm{m}^{-3}}$ was used (Table 1).

Yield $\left(\gamma_{x \notin}\right)$ and maintenance $(m)$ coefficients
Table I: Input parameters (references are given in text)

effective diffusion coefficient

$\begin{array}{lll}D_{0, g} & \left(\mathrm{~m}^{2} . \mathrm{s}^{-1}\right) & 2.1 \times 10^{-8} \\ D_{0, c} & \left(\mathrm{~m}^{2} . \mathrm{s}^{-1}\right) & 0.52 \times 10^{-9}\end{array}$

liquid/solid mass-transfer coefficient

$k_{t, s} \quad\left(m . s^{-1}\right) \quad 3.7 \times 10^{-5}$

kinetic parameters

\begin{tabular}{|c|c|c|}
\hline $\begin{array}{l}\mu_{\max } \\
K_{s} \\
Y_{m} \\
m\end{array}$ & $\begin{array}{l}\left(\mathrm{s}^{-1}\right) \\
\left(\mathrm{mol} \cdot \mathrm{m}^{-3}\right) \\
\left(\mathrm{kg} \cdot \mathrm{mol}^{-1}\right) \\
\left(\mathrm{mol} \cdot \mathrm{kg}^{-1} \cdot \mathrm{s}^{-1}\right)\end{array}$ & $\begin{array}{l}1.52 \times 10^{-5} \\
0.011 \\
1.45 \times 10^{-3} \\
9.4 \times 10^{-4}\end{array}$ \\
\hline
\end{tabular}

biomass concentrations

$\begin{array}{lll}X_{o} & \left(\mathrm{~kg} \cdot \mathrm{m}^{-3}\right) & 3.45 \times 10^{-3} \\ X_{\text {max }} & \left(\mathrm{kg} \cdot \mathrm{m}^{-3}\right) & 36.7 \\ X_{p, \text { max }} & \left(\mathrm{kg} \cdot \mathrm{m}^{-3}\right) & 950\end{array}$

colony densities

$\begin{array}{lll}\rho_{x, N b} & \left(\mathrm{~kg}^{-3}\right) & 46 \\ \rho_{x, N s} & \left(\mathrm{~kg}^{-3}\right) & 71\end{array}$

Almost no values are available for yield $\left(Y_{x s}\right)$ and maintenance coefficients $(m)$. Moreover, in most studies determinations were based on nitrogen. Available data were recalculated to oxygen yields and maintenance coefficients according to the reaction stoichiometry. As general composition formula for biomass, the relation as given by 


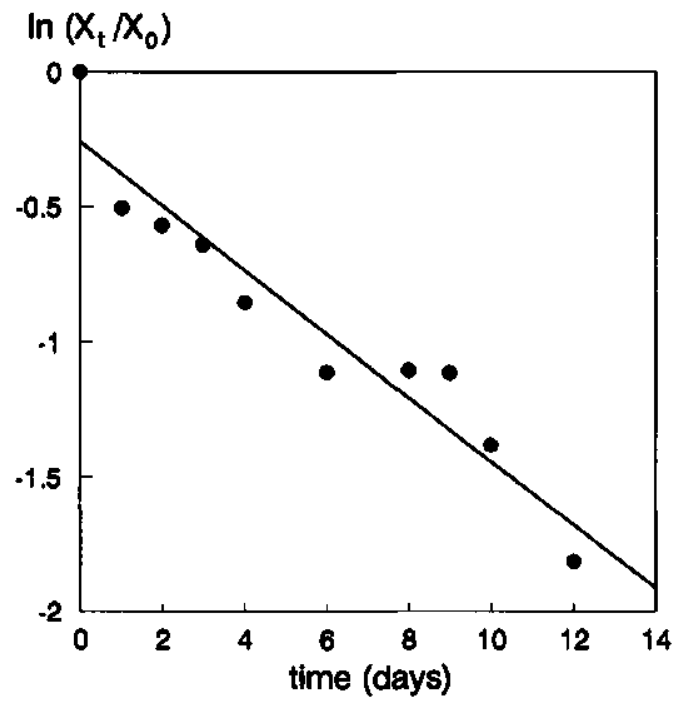

Fig. 1: Activity decrease of Nitrosomones europeee under oxygen depletion.

Roels ${ }^{29}\left(\mathrm{CH}_{1.8} \mathrm{O}_{0.5} \mathrm{~N}_{0.2}\right)$, and a cell weight of $4 \times 10^{-10} \mathrm{mg} /$ cell was used. ${ }^{12,21}$

Yield coefficients obtained from literature were averaged to $1.45 \times 10^{-3} \mathrm{~kg}$. mol ${ }^{-1} .4$

The maintenance coefficient was determined experimentally by determination of the specific biomass-degradation rate under oxygen depletion as was described before. ${ }^{42}$ According to the model of Herbert ${ }^{15}$ this degradation rate is equal to the product of $Y_{x s}$ and $m$. The specific biomass-degradation rate is equal to the slope of the curve shown in Fig. 1. This slope was $1.36 \times 10^{-6} \mathrm{~s}^{-1}$, which is $8.9 \%$ of the maximum specific growth

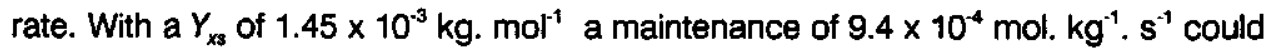
be calculated. Similar experiments were done by Laudelout et al. ${ }^{23}$ They worked both with oxygen and ammonia depletion and only ammonia depletion. In that case maintenance coefficients varied from $4.4 \times 10^{-3} \mathrm{~mol} . \mathrm{kg}^{-1} . \mathrm{s}^{-1}$ to $8.3 \times 10^{-4} \mathrm{~mol} . \mathrm{kg}^{-1} . \mathrm{s}^{-1}$, which is in the same order of magnitude as the value that we obtained. 


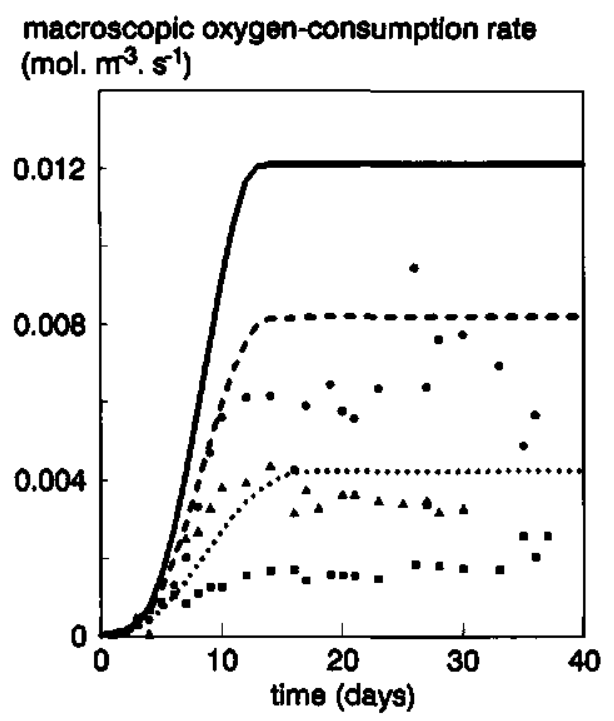

Fig. 2: Observed (markers) and predicted (lines) overall oxygen-consumption rates of immobilized Nhrosomonas europaea at different liquid-phase oxygen concentrations: $(0, \ldots) S_{b}=0.04 \mathrm{~mol}^{-\mathrm{m}^{-3}}$, $(4,-) S_{b}=0.08 \mathrm{~mol} . \mathrm{m}^{-3},(O,-) S_{b}=0.12 \mathrm{~mol}$. $\mathrm{m}^{-2}$. Predictions were done by the pseudahomogeneous growth model."

\section{Validation pseudo-homogeneous growth model with Nitrosomonas europaea}

\section{Macroscopic oxygen-consumption rate}

Macroscopic oxygen-consumption rates were determined in three separate experiments with continuous-flow air-lift loop reactors at three different liquid-phase oxygen concentrations $\left(0.04,0.08,0.12 \mathrm{~mol}^{-3} \mathrm{~m}^{-3}\right)$. Results are shown in Fig. 2. There are substantial differences between the experimentally obtained macroscopic oxygenconsumption rates and the calculated rates according to the pseudo-homogeneous growth model. ${ }^{8}$ In all cases simulated consumption rates were considerably higher than experimentally found. 


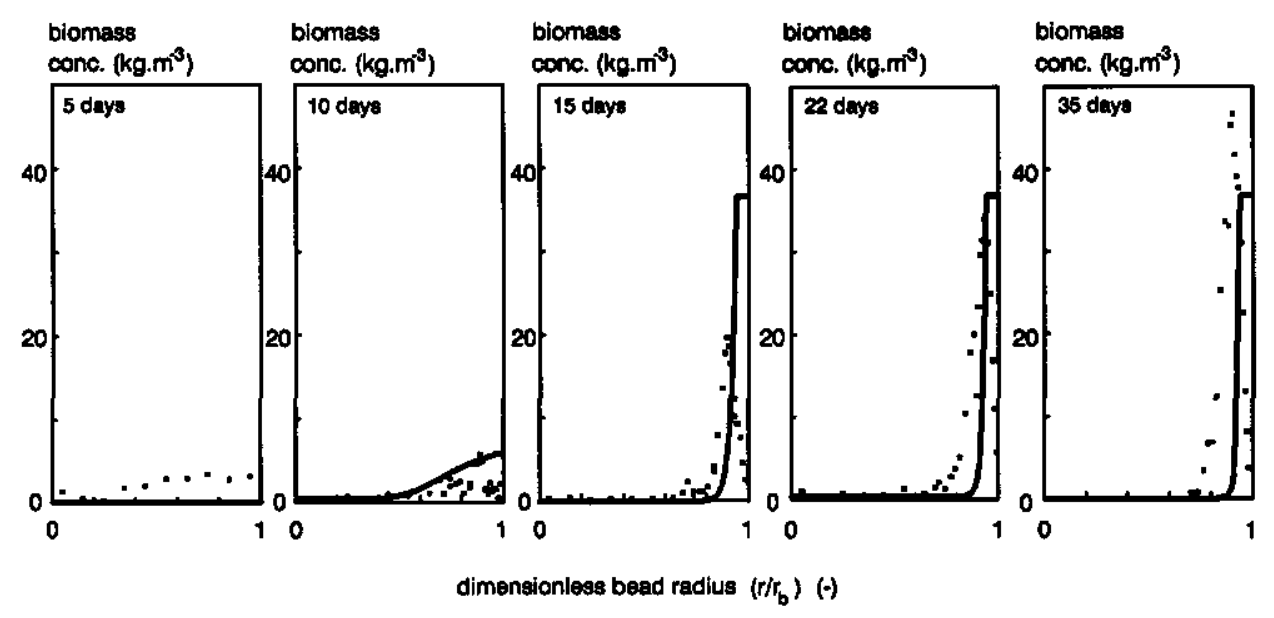

Fig. 3: Observed and simulated biomass-concentration profiles at several stages during growth of immobilized Nitrosomonas europaee. Predictions were done by the pseudo-homogeneous growth model."

Biomass-concentration profiles, maximum biomass concentration and colony density

Simulated transient-state biomass-concentration profiles were compared with experimentally obtained profiles. In Fig. 3, a clear discrepancy is observed between the measured and simulated profiles. The pseudo-homogeneous model predicts constant maximum biomass concentrations in the outer shells of the beads. The measured profiles, however, show a decrease in the biomass concentration near the bead surface ${ }^{42}$ Additionally the predicted biomass-film thickness was smaller than the observed thickness. The experimental level reached in the outer layers was $36.7 \mathrm{~kg}$. $\mathrm{m}^{-3}$ after 35 days of cultivation. 
Hypothesis for colony-expansion model with diffusion over micro-colonies

Under the experimental conditions used both biomass-concentration profiles and macroscopic consumption rates are not well described by the pseudo-homogeneous growth model. In previous experiments, however, model and experimental results agreed very well for immobilized Nitrobacter agilis cells. ${ }^{42}$ We could think of two factors that could be the reason for this difference: $\mathrm{pH}$ profiles over the support or diffusion limitation over the micro-colonies.

With the conversion of ammonia to nitrite, acid is produced. It has been shown that the effect of reduced $\mathrm{pH}$ on the activity of Nitrosomonas is considerable. At pH 6.5, the activity is only about $60 \%$ of the activity at $\mathrm{pH} 7.5 .^{18}$ Differences of $1 \mathrm{pH}$ unit between the surface and deeper layers have been observed in nitrifying biofilms. ${ }^{7.34}$ In our case, however, profiles were very flat, the difference was never more than 0.2 units as is shown in Fig. 4. Apparently the buffer capacity in the medium is sufficiently high.

Diffusion limitation over micro-colonies may be substantial in case large colonies are formed. It was shown that in the case of Nitrobacter the colony radius was at the most

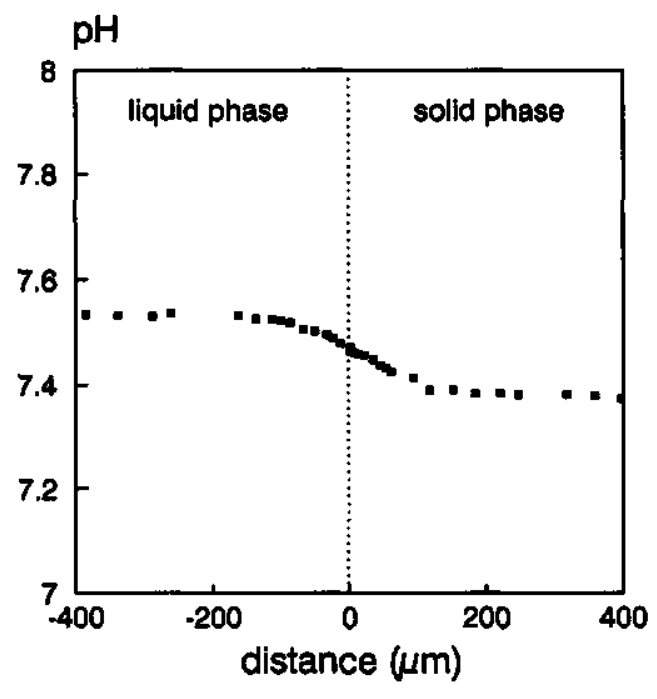

Fig. 4: Measured pH profile over a gel bead with immobilized Nitrosomonas europaea. 
$23 \mu \mathrm{m} .{ }^{42}$ In the present case, however, radii up to $57 \mu \mathrm{m}$ were observed as is shown in Fig. 5. Very likely diffusion limitation occurred over the larger micro-colonies resulting in less active or even dead biomass in the interior regions of the microcolonies. Diffusion limitation over the micro-colonies thus results in a lower macroscopic consumption rate than expected on the basis of the pseudohomogeneous growth model ${ }^{8}$ and could explain our results. To check this hypothesis, the observed surface of colonies per surface area of coupe was plotted as a function of maximum volumetric activity. The results are shown in Fig. 6 . It is clear that the obtained plot is not linear. At higher relative colony surface areas, the ratio volumetric activity/colony surface area decreases, indicating that not all biomass in the colonies is active under the experimental conditions.

For this reason the model was adapted by describing immobilized-cell growth by expansion of bacterial colonies over which diffusion limitation occurs.
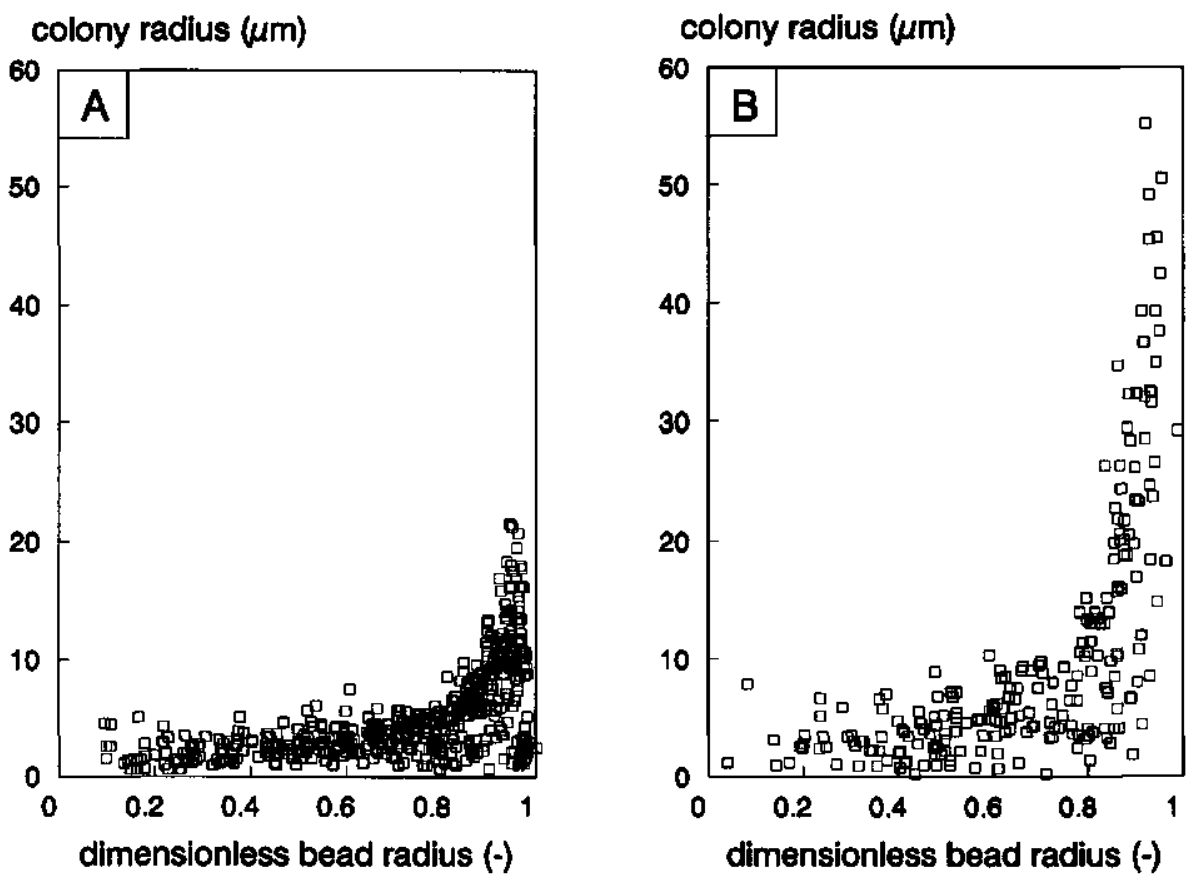

Fig. 5: Measured colony radii as a function of radial position within a get bead for Nitrobacter agilis (A) and Nitrosomanas europaea (B). 
maximum oxygen-consumption rate (mol. $\left.\mathrm{m}^{-3} . \mathrm{s}^{-1}\right)$

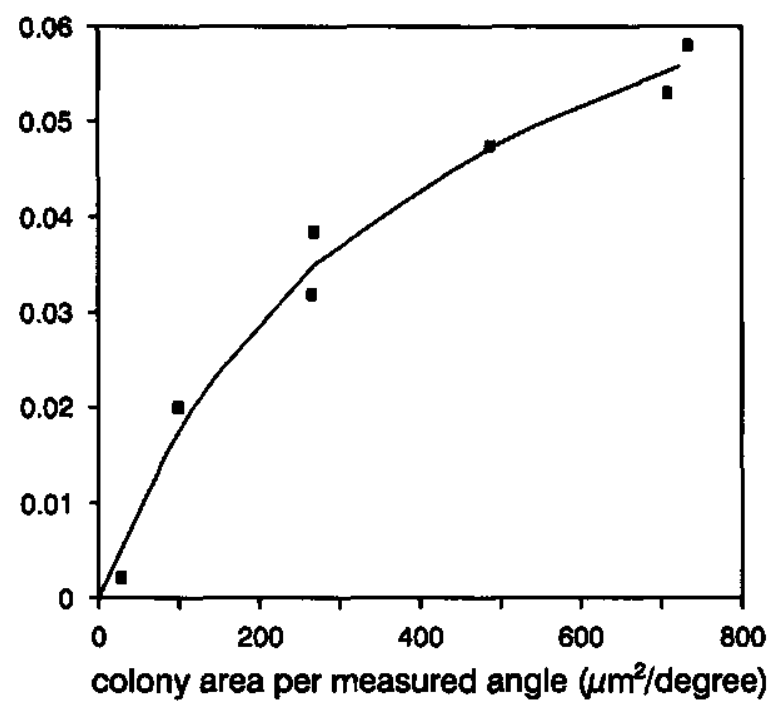

Fig. 6: Maximum oxygen-consumption rate of immoblized Nitrosomonas europaea as a function of the relative surface area of colonies in microscopical slice of a gel bead.

\section{Validation of the colony-expansion model with Nitrosomonas europaea}

\section{Model results}

A typical result of the model is shown in Fig. 7. There is a slight difference between the four typical phases of this new colony-expansion model and the pseudohomogeneous growth model. ${ }^{8}$ While in the original model the biomass concentration reaches a maximum and constant value just under the bead surface, a peak in biomass concentration is shown in the colony-expansion model. As growth near the surface proceeds in time, colonies expand until the surface of the beads is reached. Obviously growth of the colonies continues when the bead surface is reached and leads to biomass release by colony eruption or single-cell leakage. 

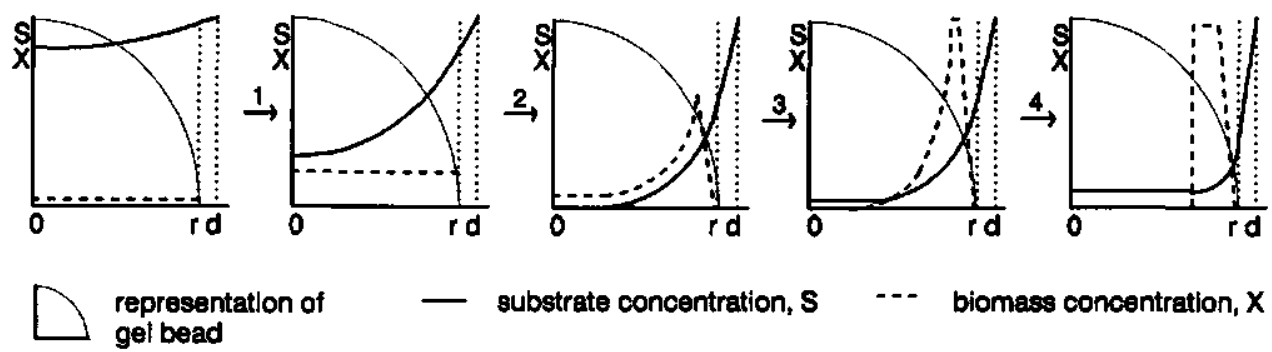

- substrate concentration, $\mathrm{S}$

- biomass concentration, $X$

Fig. 7: Typical results of the colony-expansion model for the growth of immobilized cells at various times; $d$ represents the stagnant liquid layer surrounding the beads.

Macroscopic oxygen-consumption rate

The colony-expansion model with both biomass release mechanisms was evaluated by comparing simulations with the experimentally obtained macroscopic consumption rates of immobilized Nitrosomonas europaea. The model with single-cell release still resulted in overestimations as is shown in Fig. $8 \mathrm{~A}$, although less than with the pseudohomogeneous growth model. The colony-expansion model with eruption matched best with experimentally determined macroscopic consumption rates (Fig. 8B). The sawtooth form of the curves with colony eruption is peculiar. This shape is not the result of instabilities in calculations but can be explained by eruption of the colonies. Colonies which are centred on the same shell in the gel bead expand until the surface is reached. These colonies will erupt simultaneously as the expansion is synchrone. The size of the saw teeth is decreased in case more shells are used in the calculation procedure. In average, however, the same macroscopic consumption rates are reached.

In Fig. 9A the effectiveness factor over the micro-colonies as a function of the radius of the beads is shown at different pseudo-steady states. It is shown that diffusion limitation over micro-colonies indeed is considerable in the region where the biomass concentration is highest (outer $100 \mu \mathrm{m}$ of the bead). After 35 days an effectiveness factor of about 0.2 at a depth of $50 \mu \mathrm{m}$ is reached. It is shown that as a function of 
macroscopic oxygen-consumption rate macroscopic oxygen-consumption rate (mol. $\left.\mathrm{m}^{3} \cdot \mathrm{s}^{-1}\right)$

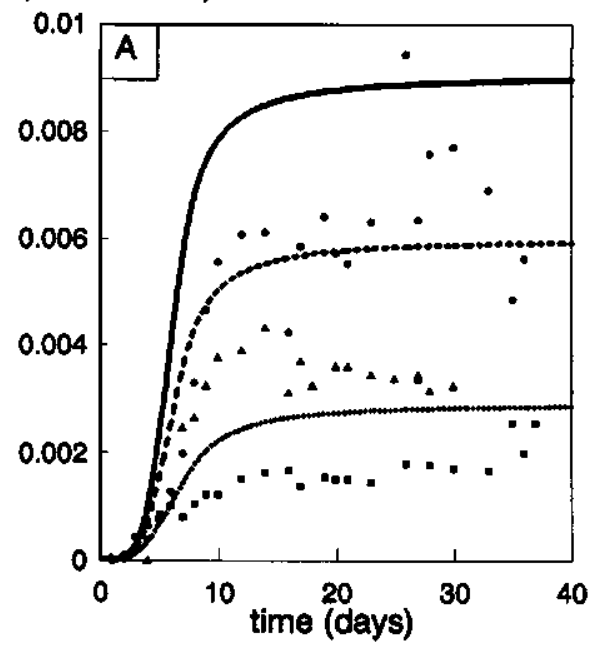
$\left(\mathrm{mol} . \mathrm{m}^{-3} \cdot \mathrm{s}^{-1}\right)$

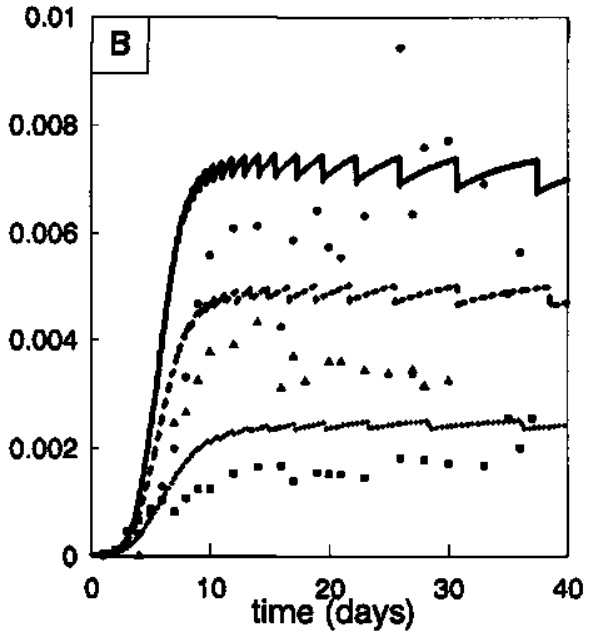

Fig. 8: Observed (markers) and predicted (lines) overall oxygen-consumption rates of immobilized Nitrosomonas europaea at different liquid phase oxygen concentrations: $(n, \ldots.) S_{b}=0.04 \mathrm{~mol}^{-\mathrm{m}^{-3}}$, $(4,-) S_{b}=0.08 \mathrm{~mol} . \mathrm{m}^{-3},(0,-) S_{b}=0.12 \mathrm{~mol}$. $\mathrm{m}^{-3}$. Predictions were done by the colonyexpansion model incorporating single-cell leakage (A) or with colony eruption (B).
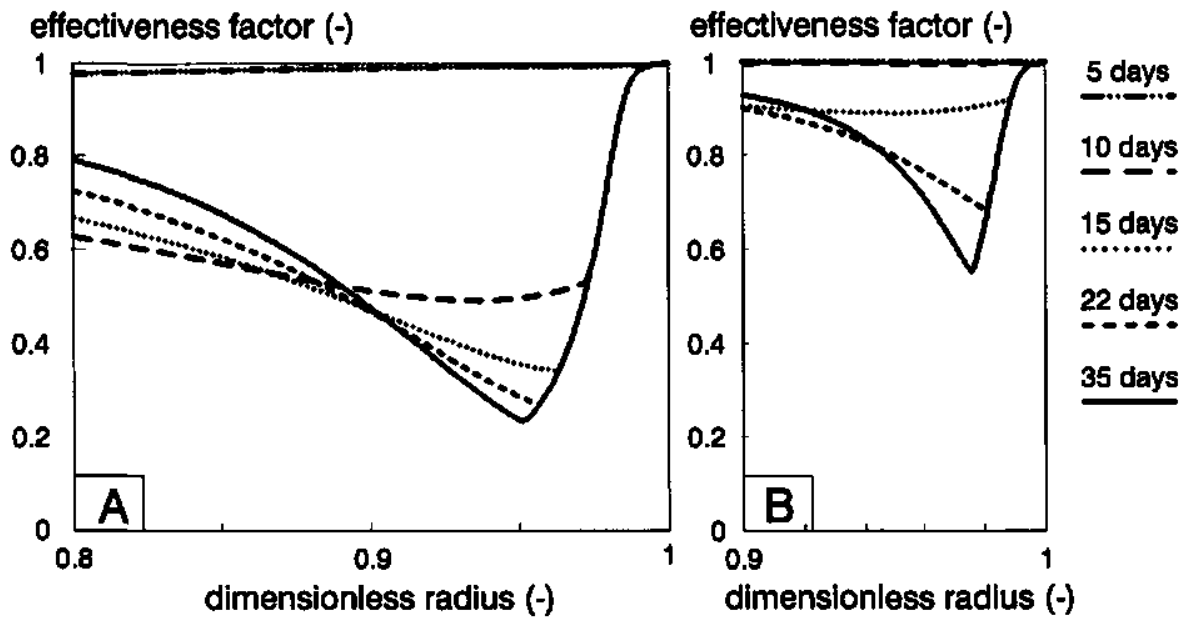

Fig. 9: Calculated effectiveness factors for micro-colonies as a function of the relative bead radius after 5, 15, 22 and 35 days of cultivation of immobilized Nitrosomonas europaea (A) and immobilized Nhrobacter agills (B) cells. 
time diffusion limitation over micro-colonies becomes higher, both as the result of increasing colony sizes and decreasing substrate concentrations. Towards the centre of the beads the effectiveness factors increase again because the colonies are very small there.

\section{Biomass-concentration profiles}

Calculated transient-state biomass-concentration profiles with the colony-expansion model including colony eruption were compared with experimentally obtained profiles. It is shown in Fig. 10 that the shape of the simulated curves is more in agreement with reality than in the case of the pseudo-homogeneous growth model as presented in Fig. 3. There are, however, still some differences, as the calculated peak is higher and the experimentally obtained biofilm is thicker. The latter may be caused by the fact that we assumed that growth results in expansion of colonies. As a result, negative growth results in negative expansion. This is, however, not likely to happen. Probably a

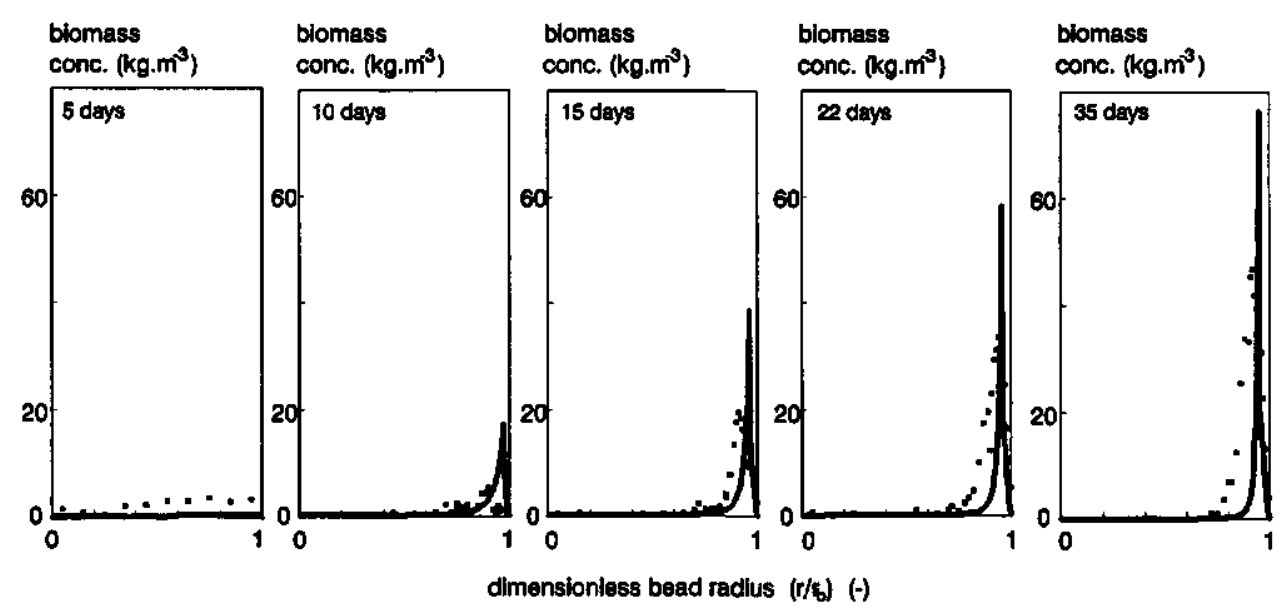

Fig. 10: Observed and simulated blomass-concentration profiles at several stages during growth of immobilized Nitrosomonas europaea. Predictions were done by the colony-expansion model incorporating colony eruption. 
decrease in biomass concentration would result in a gradient of viability over the micro-colonies and would not result in a decreased colony size. In order to quantify this effect a viability staining method would have to be applied for determination of the biomass concentration profile. The biomass-concentration profile that we determined does not discriminate for viability, while the colony-expansion model does.

\section{Validation colony-expansion model with Nitrobacter agilis}

It has been shown that in the case of Nitrosomonas europaea cells diffusion limitation over micro-colonies has to be considered. For this purpose the colonyexpansion model was developed. In our previous research with Nitrobacter agilis diffusion limitation did not seem to have influence. ${ }^{8,42}$ The colony-expansion model that was developed is meant to have a general applicability. This means that also the previous experiments with Nitrobacter agilis should be described by the colonyexpansion model including colony eruption. The macroscopic consumption rate is

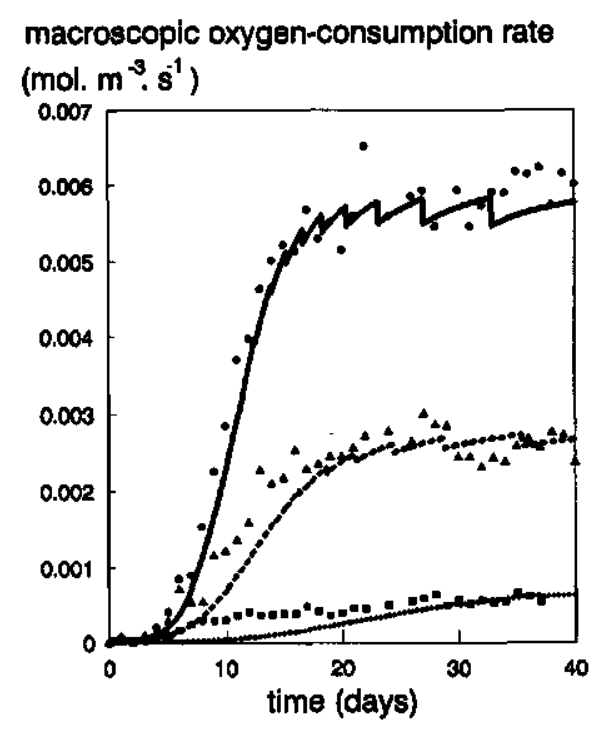

Fig. 11: Observed (markers) and predicted (lines) overall oxygen-consumption rates of immobilized Nitrobacter agills at different liquid-phase oxygen concentrations: $(\omega, \ldots) S_{b}=0.012 \mathrm{~mol}^{-3} \mathrm{~m}^{-3},(4$, $\rightarrow S_{b}=0.038 \mathrm{~mol} . \mathrm{m}^{-3},\left(0, \longrightarrow S_{b}=0.08 \mathrm{~mol}^{-3} \mathrm{~m}^{-3}\right.$. Predictions were done by the colonyexpansion model incorporating colony eruption. 
described well by the model (Fig. 11). The reason that both the pseudo-homogeneous growth model and the colony-expansion model can be applied for Nitrobacter agilis is that diffusion limitation over micro-colonies is almost negligible (Fig. 9B).

\section{CONCLUSIONS}

A dynamic model has been developed for growth of nitrifying bacteria immobilized in carrageenan gel beads. In this model growth occurs by expansion of micro-colonies until cells erupt from the gel bead or are limited in their growth by diffusion limitation. Diffusion limitation over micro-colonies has been considered as well.

Experiments with both immobilized Nitrosomonas europaea and Nitrobacter agilis showed that steady and transient states are described satisfactorily with this colonyexpansion model incorporating colony eruption. This specific model is based on general equations and on intrinsic kinetics of the immobilized cells and can thus be used in a general way to predict capacities in reactors with any kind of immobilized bacteria at defined conditions.

As diffusion limitation plays a significant role, the inoculum size will very likely affect the capacity that can be reached in the process. At high initial biomass concentrations, many small micro-colonies will be formed. At low initial biomass concentrations, less but larger colonies will be formed, over which diffusion limitation plays a more important role, probably resulting in lower capacities. In our future research we will pay attention to this effects by comparing small and large inoculum sizes.

\section{LIST OF SYMBOLS}

$D_{\theta, c}=$ effective diffusion coefficient in micro-colonies

$$
\begin{array}{r}
\left(\mathrm{m}^{2} \cdot \mathrm{s}^{-1}\right) \\
\left(\mathrm{m}^{2} \cdot \mathrm{s}^{-1}\right) \\
\left(\mathrm{m} . \mathrm{s}^{-1}\right) \\
\left(\mathrm{mol} \cdot \mathrm{m}^{-3}\right) \\
\left(\mathrm{mol} . \mathrm{kg}^{-1} \cdot \mathrm{s}^{-1}\right)
\end{array}
$$$$
D_{\theta, \theta} \quad=\text { effective diffusion coefficient in gel }
$$$$
k_{l, s} \quad=\text { liquid/solid mass-transfer coefficient }
$$$$
K_{s}=\text { Monod constant }
$$$$
m \quad=\text { maintenance coefficient }
$$$$
r \quad=\text { distance from the centre of the bead }
$$$$
r_{b} \quad=\text { radius of the bead }
$$ 
$r_{f}=$ distance from the centre of the bead where the substrate concentration is negligible

$r_{s} \quad=$ macroscopic consumption rate (mol. $\left.\mathrm{m}^{-3} \cdot \mathrm{s}^{-1}\right)$

$r_{s, a}=$ actual substrate-consumption rate in colonies (mol. $\left.\mathrm{m}^{-3} \cdot \mathrm{s}^{-1}\right)$

$r_{s, t}=$ theoretical substrate-consumption rate in colonies (mol. $\mathrm{m}^{-3} \cdot \mathrm{s}^{-1}$ )

$S$ = substrate concentration (mol. $\mathrm{m}^{-3}$ )

$S_{b} \quad=$ substrate concentration in the bulk

$S_{1}=$ substrate concentration at colony/gel interface

$S_{s}=$ substrate concentration at the surface of the bead (mol. $\left.\mathrm{m}^{-3}\right)$ (mol. $\left.\mathrm{m}^{-3}\right)$ (mol. $\mathrm{m}^{-3}$ )

$t=$ time

$x=$ biomass concentration

$X_{c}=$ biomass concentration in micro-colonies

$x_{0}=$ biomass concentration at $\mathrm{t}=0$

$x_{\max }=$ maximum biomass concentration

$X_{\text {pmax }}=$ maximum physically attainable biomass concentration (kg. $\left.\mathrm{m}^{-3}\right)$

$X_{t}=$ biomass concentration at $\mathrm{t}=\mathrm{t}$ (kg. $\left.\mathrm{m}^{-3}\right)$

$Y_{x s} \quad=$ molar substrate yield $\left(\mathrm{mol} . \mathrm{kg}^{-1}\right)$

$\eta(r)_{c}=$ effectiveness factor over micro-colonies at bead radius $\mathrm{r}$

$\mu(r)=$ specific growth rate at radius $r$

$\mu_{\max }=$ maximum specific growth rate

$\rho=$ distance from the centre of the colony

$\rho_{c} \quad=$ colony radius

$\rho_{c,(0)}^{\prime}=$ colony radius at $\mathrm{r}$ at time $=\mathrm{i}$

$\rho_{x, N b}=$ colony density Nitrobacter

$\rho_{x, N s}=$ colony density Nitrosomonas

$\rho_{t} \quad=$ distance from the centre of the colony where the substrate concentration is negligible

\section{ACKNOWLEDGEMENT}

We wish to thank Dr. D. de Beer for helping us with the determination of $\mathrm{pH}$ profiles and Mr. D. Schoonderbeek for assistance with the image-analysis equipment. 
Diffusion limitation over expanding micro-colonies

\section{LITERATURE}

1. Barnes D., Bliss P.J. (1983) Biological control of nitrogen in wastewater treatment. E. \& F.N. Spon, London $146 \mathrm{p}$

2. Beeftink H.H., Van Der Heijden R.T.J.M., Heijnen J.J. (1990) Maintenance requirements: energy supply from simultaneous endogenous respiration and substrate consumption. FEMS Microbiol Ecol 73: 203-210

3. Belser L.W. (1984) Bicarbonate uptake by nitrifiers: effect of growth rate, pH, substrate concentration and metabolic inhibitors Appl Env Microbiol 48: 1100-1104

4. Belser L.W., Schmidt E.L. (1980) Growth and oxidation kinetics of three genera of ammonia oxidizing nitrifiers. FEMS Microbiol Letters, 7: 213-216 (1980)

5. Bock E. (1965) Vergleichende Untersuchungen über die Wirkung sichtbaren Lichtes auf Nitrosomonas europaea und Nitrobacter winogradskyi. Arch Microbiol 51: 18-41

6. Dalili M., Chau P.C. (1987) Intraparticle diffusional effects in immobilized cell particles. Appl Microbiol Biotechnol 26: 500-506

7. De Beer D., Van Den Heuvel J.C., Ottengraf S.P.P. (1993) Microelectrode measurements of the activity distribution in nitrifying bacterial aggregates. Appl Environm Microbid 59: 573-579

8. De Gooljer C.D., Wijffels R.H., Tramper J. (1991) Growth and substrate consumption of Nitrobacter agilis cells immobilized in carrageenan: part 1. dynamic modeling. Biotechnol Bioeng 38: 224-231

9. De Gooljer C.D., Wijffels R.H., Tramper J. (1992) Dynamic modeling the growth of immobilized nitrifying bacteria: biofilm development. In: Biofilms-Science and Technology. Eds. L.F. Melo, T.R. Bott, M. Fletcher, B. Capdeville. Kluwer Academic Publishers, The Netherlands, p 291-296

10. Dhulster P., Barbotin J.N., Thomas D. (1984) Culture and bioconversion use of plasmid-harboring strain of Immobilized E. coli. Appl Microbiol Biotechnol 20: 87-93

11. Engel M.S., Alexander M. (1958) Culture of Nitrosomonas europaea in media free of insoluble constituents. Nature 181: 136

12. Engel M.S., Alexander M. (1958) Growth and autotrophic metabolism of Nitrosomonas europaea. J Bacteriol 76: 217-222

13. Greenberg A.E., Trussel R.R., Clesceri L.S. (1985) Standard methods for the examination of water and wastewater. 16th ed., American Public Health Association, Washington DC, $1268 \mathrm{p}$

14. Gujer W., Boller M. (1989) A mathematical model for rotating biological contactors. In: Proceedings of technical advances in bioreactors conference, Nice, CFRP-AGHTM Paris, p 69-89

15. Herbert D. (1959) Some principles of continuous culture. In: Recent Progress in Microbiology. Ed. G. Tunevall. Almquist \& Wicksell, Stockholm, p 381-396

16. Ho C.S., Ju L-K. (1988) Effect of microorganisms on oxygen diffusion coefficients and solubilities in fermentation media. Biotechnol Bioeng 32: 313-325

17. Hooper A.B., Terry K.R. (1974) Photo inactivation of ammonia oxidation in Nitrosomonas. J Bacterld 119: 899-906 
18. Hunik J.H., Bos C.G., Van Den Hoogen M.P., De Gooljer C.D., Tramper J. (1994) Coimmobilized Nitrosomonas europaea and Nitrobacter agilis cells: validation of a dynamic model for simultaneous substrate conversion and growth in k-carrageenan gel beads. Biotechnol Biceng. In press

19. Hunik J.H., Meijer H.J.G., Tramper J. (1992) Kinetics of Nitrosomonas europaea at extreme substrate, product and salt concentrations. Appl Microbiol Biotechnol 37: 802-807

20. Inloes D., Smith W., Taylor D., Cohen S., Michaels A.S., Robertson C.R (1983) Hollow-fiber membrane reactors using immobilized $E$. coli for protein synthesis. Biotechnol Bioeng 25: 2653-2681

21. Keen G.A., Prosser J.I. (1987) Steady state and transient growth of autotrophic nitrifying bacteria. Arch Microbiol 147: 73-79

22. Laudelout H., Lambert R., Pham M.L. (1976) Influence du pH et de la pression partielle d'oxygene sur la nitrification. Ann Microbiol (Inst Pasteur) 127a: $367-382$

23. Laudelout H., Simonart P.C., Van Droogenbroeck R. (1968) Calorimetric measurement of free energy utilization by Nitrosomonas and Nitrobacter. Arch Microbiol 63: 256-277

24. LibickI S.B., Salmon P.M., Robertson C.R. (1988) The effective diffusive permeability of a nonreacting solute in microbial cell aggregates. Biotechnol Bioeng 32: 68-85

25. Loveless J.E., Painter H.A. (1968) The influence of metal ions and pH value on the growth of Nitrosomonas strains isolated from activated sludge. J Gen Microbiol 52: 1-14

26. Meiklejohn J. (1953) Iron and the nitrifying bacteria. J Gen Microbiol 8: 58-65

27. Monbouquette H.G., Sayles G.D., Ollis D.F. (1990) Immobilized cell biocatalyst activation and pseudo-steady-state behavior: model and experiment. Biotechnol Bioeng 35: 609-629

28. Peeters T.L., Van Gool A.P., Laudelout H. (1969) Kinetic study of oxygen-limited respiration in nitrifying bacteria. Am Soc Microbiol, Bact Proc. Washington DC, p 141

29. Roels J.A. (1983) Energetics and kinetics in biotechnology. Elsevier Biochemical Press, Amsterdam

30. Salmon P.M. (1989) Mass transport phenomena in reactors containing entrapped enzymes or bacterial cells. PhD thesis Stanford University, USA

31. Sato C.S., Schnoor J.L., MCDonald D.B., Huey J. (1985) Test medium for the growth of Nitrosomonas europaea. Appl Env Microbiol 49: 1101-1107

32. Skinner F.A., Walker N. (1961) Growth of Nitrosomonas europaea in batch and continuous culture. Arch Microbiol 38: 339-349

33. Stewart P.S., Robertson C.R. (1989) Microbial growth in a fixed volume: studies with entrapped Escherichia coli. Appl Microbiol Biotechnol 30: 34-40

34. Szwerinski H., Arvin E., Harremoes P. (1986) pH-decrease in nitrifying biofilms. Water Research 20: $971-976$

35. Taxis du Poet P., Dhulster P., Barbotin J.N., Thomas D. (1986) Plasmid stability and biomass production: comparison between free and immobilized cell cultures of Escherichia coli BZ18(pTG201) without selection pressure. J Bacteriol 165: 871-877 
36. Tomlinson T.G., Boon A.G., Trotman C.N.A. (1966) Inhibition of nitrification in the activated sludge process of sewage disposal. J Appl Bact 29: 266-291

37. Underhill S.E., Prosser J.I. (1987) Inhibition and stimulation of nitrification by potassium ethyl xanthate. J Gen Microbiol 133: 3237-3245

38. Van Droogenbroeck R., Laudelout H. (1967) Phosphate requirements of nitrifying bacteria. Ant Leeuwenh 33: 287-296

39. Van Ginkel C.G., Tramper J., Luyben K.Ch.A.M., Klapwijk A. (1983) Enzyme Microb Technol 5: $297-303$

40. Van Neerven A.R.W., Wijfels R.H., Zehnder A.J.B. (1990) Scanning electron microscopy of immobilized bacteria in gel beads: a comparative study of fixation methods. J Microbiol Meth 11: $157-168$

41. Westrin B.A., Axelsson A. (1991) Diffusion in gels containing immoblized cells: a critical review. Biotechnol Bloeng 36: 439-446

42. Wijfels R.H., De Gooijer C.D., Kortekaas S., Tramper J. (1991) Growth and substrate consumption of Nitrobacter agillis cells immoblized in carrageenan: part 2. model evaluation. Biotechnol Bioeng 38: 232-240

43. Wijffels R.H., Englund G., Hunik J.H., Leenen E.J.T.M., Bakketun A., Günther A., Obón de Castro J.M., Tramper J. (1994) Effects of diffusion limitation on immobilized nitrifying microorganisms at low temperatures. Submitted for publication

44 Yoshioka T., Saijo Y. (1984) Photo inhibition and recovery of $\mathrm{NH}_{4}{ }^{+}$-oxidizing bacteria and $\mathrm{NO}_{2}{ }^{-}$ oxidizing bacteria. J Gen Appl Microbiol 30: 151-166 


\section{INTERMEZZO}

Substrate is transferred from the surface of the gel bead to the centre of the beads. The concentration of bacteria near the surface is so high that most of the oxygen is consumed in the outer shells of the bead: a gradient in oxygen concentration will develop. We calculated this profile and evaluated it experimentally with micro-electrodes.

The concentration of oxygen can be measured by electrodes. At the University of Amsterdam, electrodes were developed with a very thin tip (less than $10 \mu \mathrm{m}$ ). With such a micro-electrode it is possible to penetrate in a gel bead and measure the oxygen concentration at several depths.

Calculated and measured concentration profiles were compared at different stadia of the process. One of the results is shown: the calculated profile is given by the line and the experimental profile by the data points. 


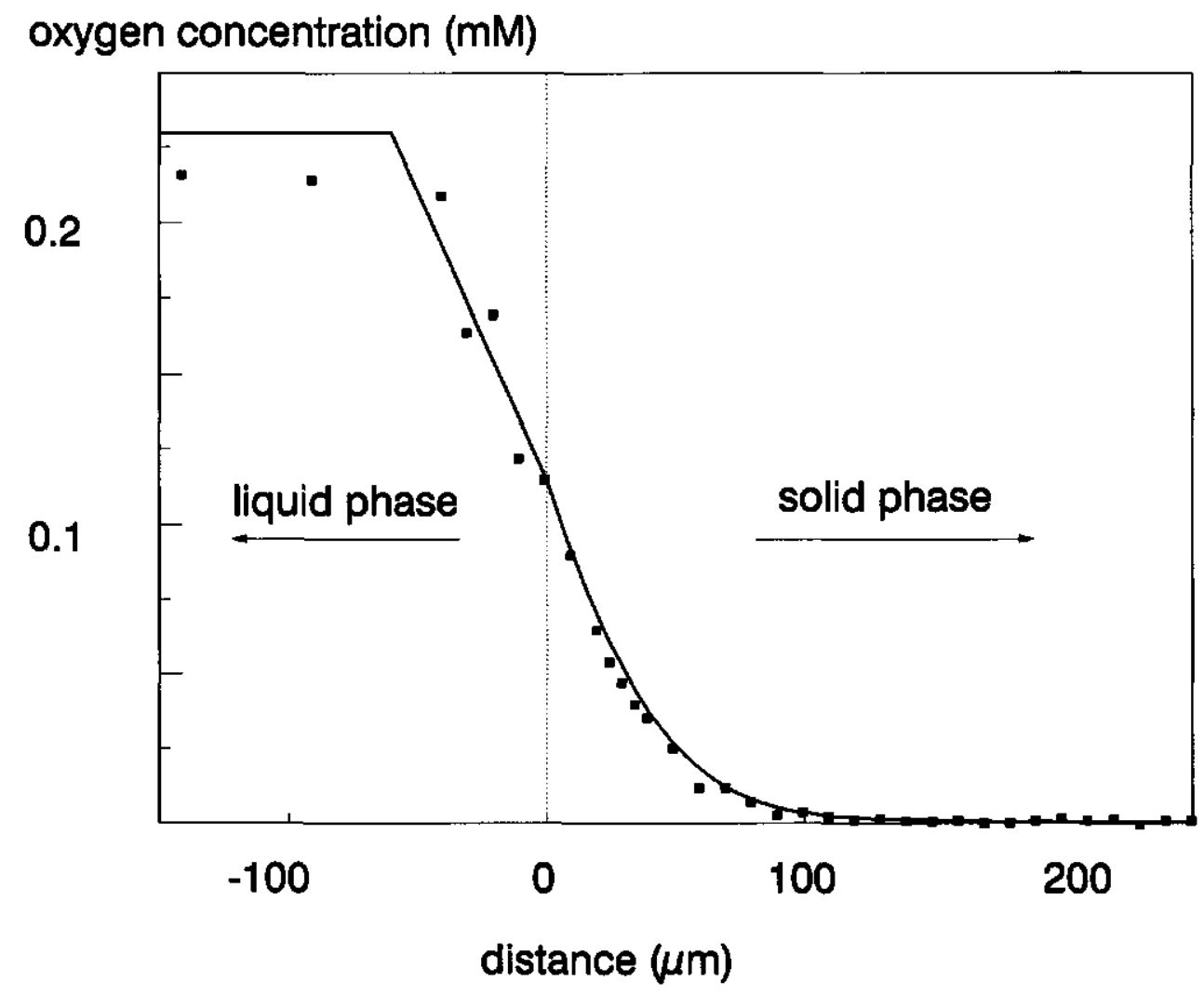


This chapter has been submitted for publication by the authors R.H. Wijfels A.W. Schepers, M.

Smit, C.D. de Gooijer and J. Tramper

\section{CHAPTER 7}

\section{EFFECT OF INITIAL BIOMASS CONCENTRATION ON THE GROWTH OF IMMOBILIZED NITROSOMONAS EUROPAEA}

\section{ABSTRACT}

Nitrosomonas europaea was immobilized in carrageenan-gel beads with a low and a high biomass concentration (factor 100 difference). Under growth conditions in a continuous air-lift loop reactor, a low initial concentration yielded few large microcolonies per bead, while a high initial biomass concentration resulted in many small micro-colonies per bead. The macroscopic-consumption rate of the latter was 3 times higher under the applied circumstances. This is also predicted by our colonyexpansion model when diffusion limitation over the micro-colonies is incorporated. This model also predicts that diffusion limitation over the ultimate colonies is negligible when the initial biomass concentration exceeds $0.5 \mathrm{~kg} . \mathrm{m}^{-3}$ carrageenan gel. 


\section{INTRODUCTION}

Growth of immobilized cells has been studied extensively in recent years. The main advantage of the use of immobilized cells is that the liquid-retention time in continuous bioreactors can be separated from the biomass-retention time. As a consequence, immobilization is especially advantageous in the case of slowly growing microorganisms in continuous bioreactors. In such bioreactors the biomass concentration is much higher than in reactors with suspended cells resulting in higher volumetric capacities.

One of the disadvantages of immobilized-cell processes is the occurrence of diffusion limitation over the support, resulting in an on average lower cell activity. Another capacity reducing effect is the occurrence of diffusion limitation over microcolonies. This was shown in our previous research in which we studied growth of immobilized nitrifying bacteria in gel beads. Initially, only diffusion limitation over the gel bead was considered. ${ }^{2,7}$ Diffusion limitation over the micro-colonies, however, also appears to play a significant role under some conditions. ${ }^{8}$

Qualitatively the process can be described as follows. Growth in a gel bead results in the formation of micro-colonies. As growth proceeds, colonies expand until the surface of the beads is reached and further expansion leads to eruption of colonies from the beads into the surrounding liquid phase. The rate of expansion is limited both by diffusion limitation over the gel bead and micro-colonies, at least when the latter exceed a certain size.

In case diffusion limitation over micro-colonies is indeed important, this will also affect the overall capacity of the immobilized-cell reactor. Due to this colonial diffusion limitation the capacity that can ultimately be reached is influenced by the inoculum size. At high initial biomass concentrations, many small micro-colonies will be formed with little diffusion limitation. At low initial biomass concentrations, less but larger colonies will be formed, over which diffusion limitation plays an important role, resulting in lower capacities. In the study presented here, effects of inoculum size were studied. There was a difference of a factor 100 in the inoculum size. The capacity reached in both reactors was determined experimentally and compared with model calculations. Model calculations were done by the colony-expansion model with colony eruption as was described previously. ${ }^{8}$ Model input parameters were the same as used in that research and are summarized in Table I. Additionally, both processes were monitored 
Table I: Input parameters."

physical parameters

effective diffusion coefficient in gel effective diffusion coefficient in colony liquid/solid mass-transfer coefficlent

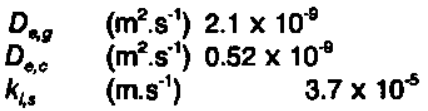

\section{kinetic parameters}

maximum specific growth rate

Monod constant

molar substrate yield

maintenance coefficient

colony density

$\begin{array}{lll}\mu_{\max } & \left(\mathrm{s}^{-1}\right) & 1.52 \times 10^{-5} \\ K_{\mathrm{s}} & \left(\mathrm{mol} . \mathrm{m}^{-3}\right) & 0.011 \\ Y_{x s} & \left(\mathrm{~kg} \cdot \mathrm{mol}^{-1}\right) & 1.45 \times 10^{-3} \\ m & \left(\mathrm{~mol} . \mathrm{kg}^{-1} \mathrm{~s}^{-1}\right) & 9.4 \times 10^{-4} \\ \rho_{x} & \left(\mathrm{~kg} \cdot \mathrm{m}^{-3}\right) & 71\end{array}$

microscopically to study differences in colony size and shape. It is shown that by increasing the inoculum size, effects of diffusion limitation over micro-colonies can be avoided, and by that the capacity increased.

\section{MATERIALS AND METHODS}

\section{Suspended and immobilized-cell cultivation and immobilization procedure}

Cultivation of Nitrosomonas europaea was done in a $2.8 \mathrm{dm}^{3}$ continuous culture at a dilution rate of $3.47 \times 10^{-6} \mathrm{~s}^{-1}$. The composition of the medium is given by Wijfels et al. ${ }^{8}$

Suspended cells were concentrated by centrifugation and then immobilized in carrageenan by the resonance-nozzle technique as described before.' Two dilutions were made in order to obtain an initial biomass concentration of $1.95 \times 10^{-3}$ and 1.95 $\times 10^{-5} \mathrm{~kg} . \mathrm{m}^{-3}$ in the gel beads. The resulting average bead diameter was $2.1 \mathrm{~mm}$ for the highest initial biomass concentration and $2.0 \mathrm{~mm}$ for the lower biomass concentration.

Immobilized cells were cultivated in continuous-flow air-lift loop reactors of $3.25 \mathrm{dm}^{3}$ under oxygen-limited conditions. The composition of the medium is given by Wiffels et al. ${ }^{8}$ The liquid-phase oxygen concentration was controlled at $0.12 \mathrm{~mol} . \mathrm{m}^{-3}$ by mixing air and nitrogen gas or air and pure oxygen and the $\mathrm{pH}$ was controlled to 7.4 as 
described before. ${ }^{8}$ The superficial gas velocity was $0.2 \mathrm{~cm} . \mathrm{s}^{-1}$, the solid-phase hold-up 0.15 and the applied dilution rate $8.85 \times 10^{-5} \mathrm{~s}^{-1}$.

\section{Oxygen-consumption rate and protein analysis}

Macroscopic oxygen-consumption rates were estimated by determination of the nitrite production rate per amount of gel as for oxidation of ammonia by Nitrosomonas stoichiometric amounts of oxygen are needed. ${ }^{1}$ Ammonia and nitrite concentrations in influent and effluent were determined using a continuous-flow analysis system (Skalar Auto Analyzer) as described before. ${ }^{8}$

Overall viable-biomass estimates were made by activity assays in a biological oxygen monitor. The activity per amount of gel was converted to a biomass-dry weight concentration by dividing by the specific activity. The specific activity of Nitrosomonas europaea is $0.01 \mathrm{~mol} . \mathrm{kg}^{-1} . \mathrm{s}^{-1.8}$.

For protein analysis, gel beads were solubilized as described by Smith et $2 l^{4} \mathrm{~A}$ known amount of beads (approximately $1 \mathrm{~g}$ ) was flash frozen in liquid nitrogen and freeze dried during 48 hours $\left(-54^{\circ} \mathrm{C}, 190 \mathrm{~Pa}\right)$. The sample was suspended in $10 \mathrm{ml}$ of demineralized water. From this $0.9 \mathrm{ml}$ was mixed with $0.1 \mathrm{ml} 5 \mathrm{M} \mathrm{NaOH}$ and heated during 20 minutes in a boiling-water bath, cooled and assayed according to the method of Lowry ${ }^{3}$ with as standard BSA.

\section{Microscopical analysis}

From both reactors samples of beads were observed macroscopically and microscopically regularly.

For macroscopic analysis, photographs of the gel beads were made using a macro lens. On these macroscopic pictures development of micro-colonies could clearly be observed.

For microscopic analysis, beads were sectioned. Before sectioning, samples were fixed chemically in $4 \%$ para-formaldehyde solution in a $0.1 \mathrm{~mol}^{-\mathrm{dm}^{-3}}$ phosphate buffer

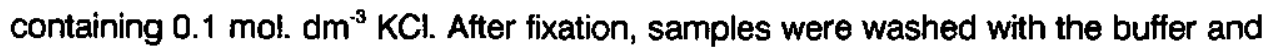
dehydrated with ethanol as described before. ${ }^{6}$ Beads were then embedded by impregnation with a series of mixtures of pure ethanol and London Resin White (low grade, Bio-Rad) in ratios of $5: 1,3: 1,1: 1$ and $1: 3$ (30 minutes per step). Finally pure 
London Resin White was used and polymerization took place at $60^{\circ} \mathrm{C}$ during 24 hours. Sections through the centre of the beads were cut with an LKB 8800 ultramicrotome with a glass knife. Sections with a thickness of $2 \mu \mathrm{m}$ were collected in a drop of water on glass slides and dried on a hot plate and stained with $0.1 \%$ toluidine blue for 5 seconds to improve the contrast between the gel and the colonies. The sections were rinsed with demineralized water, dried and mounted in glycerine. Preparations were examined with a Nikon Optiphot FXA microscope and photographs were made with a Kodak Technical Pan film 2415 at 50 ASA.

\section{RESULTS AND DISCUSSION}

Gel beads with different initial amounts of biomass were cultivated in air-lift loop reactors. Transient-state macroscopic consumption rates in both reactors were compared with simulations (Fig. 1) using the colony-expansion model with colony eruption. ${ }^{8}$ It can be observed that the capacity in the steady-state situation is much lower in case of a low initial biomass concentration. This is shown by both model macroscopic oxygen-consumption rate (mol. $\mathrm{m}^{-3} \cdot \mathrm{s}^{-1}$ )

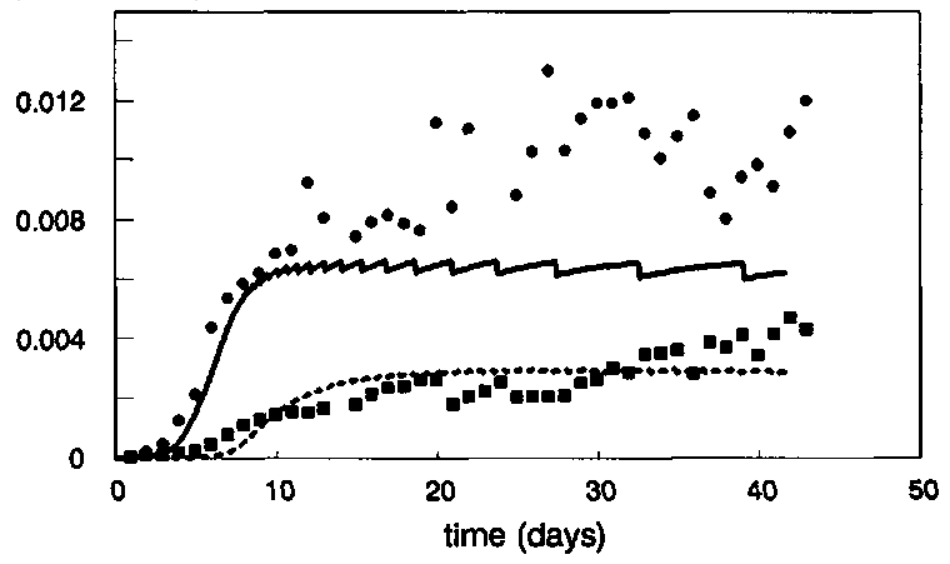

Fig. 1: Observed (markers) and predicted (lines) overall oxygen consumption rates of immobilized Nitrosomonas europaea with different initial biomass concentrations: $(n,-) X_{0}=1.95 \times 10^{-5} \mathrm{~kg} . \mathrm{m}^{-3}$ and $(\theta,-) x_{0}=1.95 \times 10^{-3} \mathrm{~kg} \cdot \mathrm{m}^{-3}$. Predictions were done by the colony-expansion model with colony eruption. 
predictions and experimental results. Experimental and model results are comparable, although at the high initial biomass concentrations the volumetric capacity reached in steady state was considerably higher in the experimental analysis. The reason for this deviation probably is biofilm formation on the reactor walls, which was observed in this particular experiment. Model results show a saw-tooth appearance of the macroscopic consumption rate. The saw tooth is the result of the method of calculation. In the model the colonies are situated in shells in the gel bead. As the result of expansion, the colonies will at a certain time reach the surface, protrude and erupt as soon as $1 / 3$ of their volume is protruded (arbitrarily chosen). This eruption process is synchrone for all colonies that are centred in a certain shell, causing the saw tooth. ${ }^{8}$ The extent of protrusion before eruption will depend on the strength and elasticity of the gel and the pressure that the colony expresses on the gel matrix. Development of internal pressure in colonies was observed before by Stewart and Robertson. ${ }^{5}$ In case the force of pressure is higher than the strength of the gel, the gel will disrupt resulting in an excretion as is shown in Fig. 2.

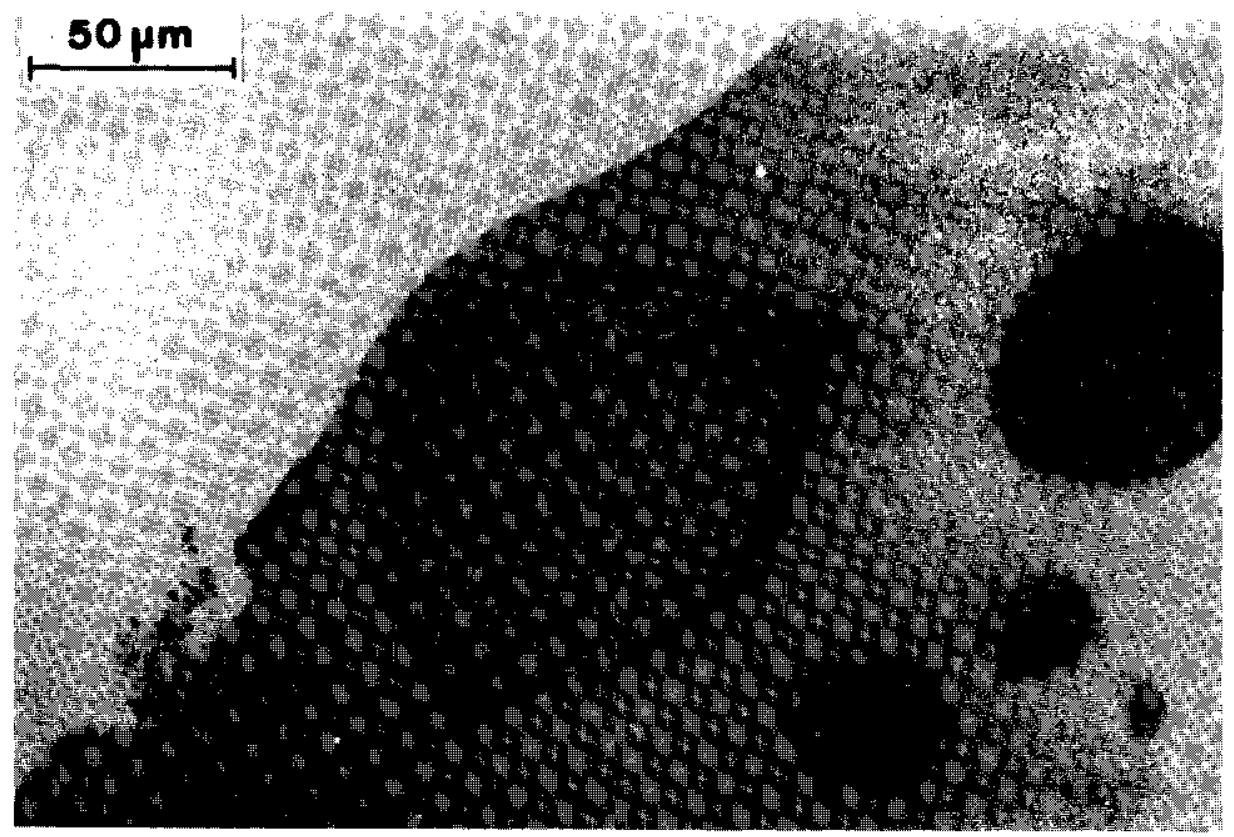

Fig. 2: Colony eruption from a gel bead. 


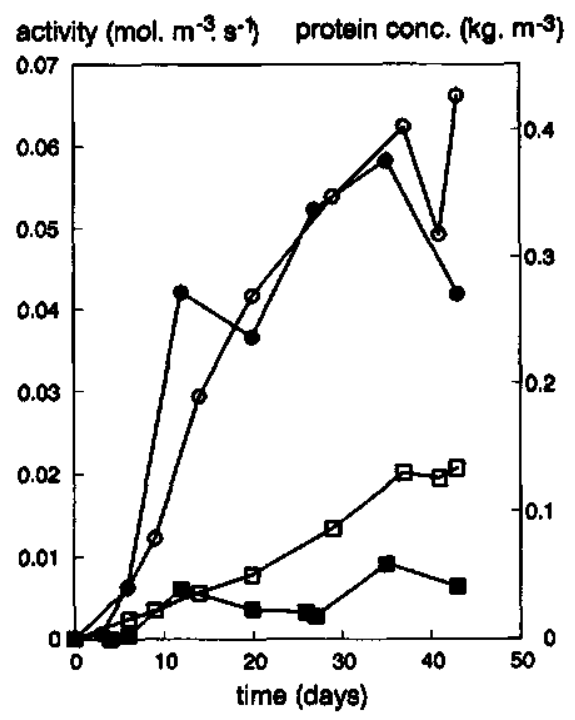

Fig. 3: Growth of immobilized Nitrosomonas europaea with an initial biomass concentration of $1.95 \times 10^{-5} \mathrm{~kg} . \mathrm{m}^{-2}$ (squares; $\mathrm{n}$, a) or $1.95 \times 10^{-3} \mathrm{~kg}$. $\mathrm{m}^{-3}$ (circles; $O$, 0 ) measured as protein concentration (open symbols; $O, \square$ ) and activity (filled symbols; $9, \square$ ).

Not only the macroscopic substrate-consumption rate was much lower with low inoculum-size beads, but also the obtained biomass concentration, measured as activity and protein concentration (Fig. 3). Fig. 3 also depicts that the ratio between activity and protein concentration is much lower in case of low inoculum-size beads, indicating that cells in that case are less active after some time of cultivation as result of diffusion limitation over the micro-colonies.

Qualitatively, growth of immobilized cells at two different biomass concentrations is shown in Figs. 4 and 5 . Samples were observed macro- and microscopically after $6,9,14,22,28,33$ and 37 days of cultivation. Figs $4 A$ and $5 A$ show complete beads with micro-colonies that were directly photographed. It is shown that in the case of a high initial biomass concentration (Fig. 4A) more colonies are formed than in the case of low initial biomass concentration (Fig. 5A). Colonies in the latter case may be larger, but the overall biomass concentration remains lower during the entire process. The growth process was observed in more detail by microscopical analysis. It is observed that in beads with a low inoculum size (Fig. 5B) larger colonies were formed 

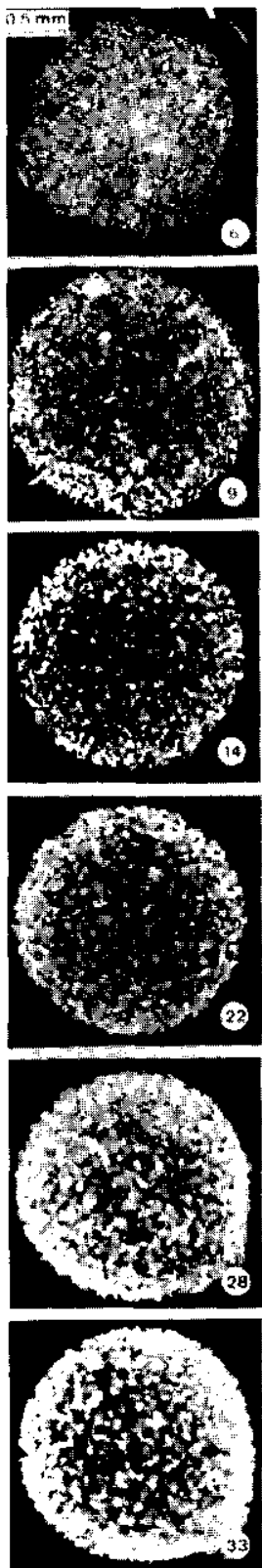

A

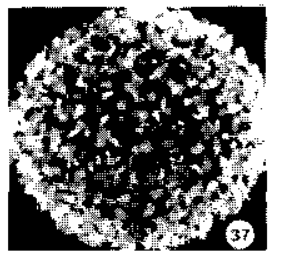

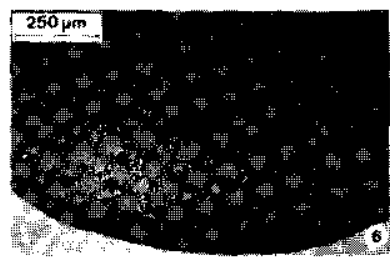
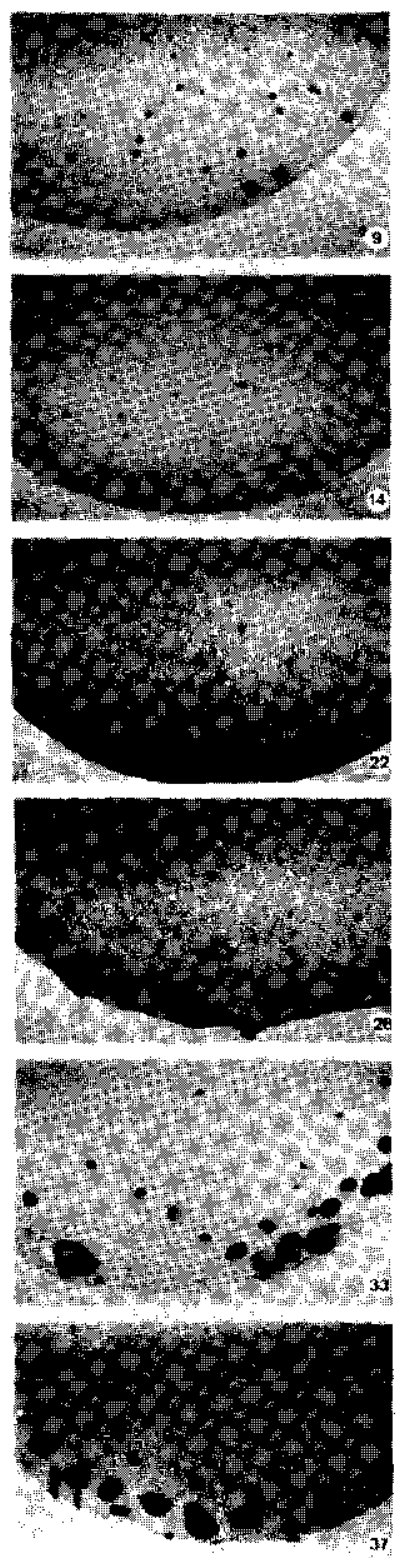

Fig. 4: Colony development for a system with immobilized cells with a high initial biomass concentration of $1.95 \times 10^{-3}$ $\mathrm{kg} \cdot \mathrm{m}^{-3}$ after $6,9,14,22,28$, 33 and 37 days of cultivation:
A) macroscopicobservation
B) microscopic observation 
Effect of initial biomass concentration
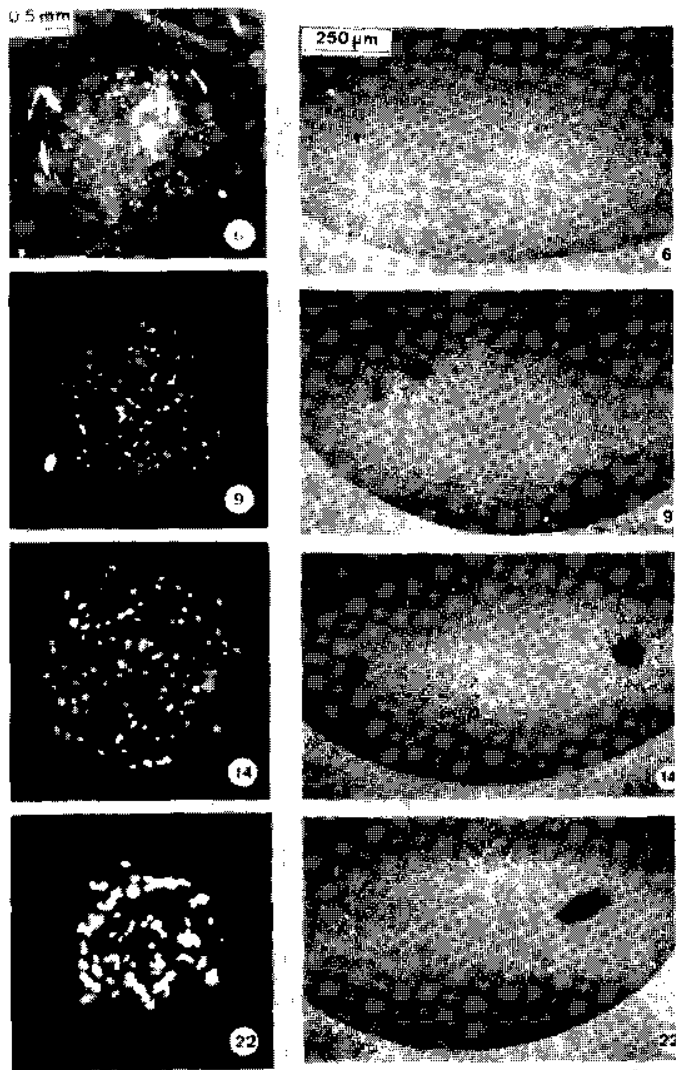

Fig. 5: Colony development for aystem with immobilized cells with a low initlal biomass concentration of $1.95 \times 10^{-5}$ $\mathrm{kg} \cdot \mathrm{m}^{-3}$ after $6,9,14,22,28$, 33 and 37 days of cultivation:

A) macroscopicobservation B) microscopic observation
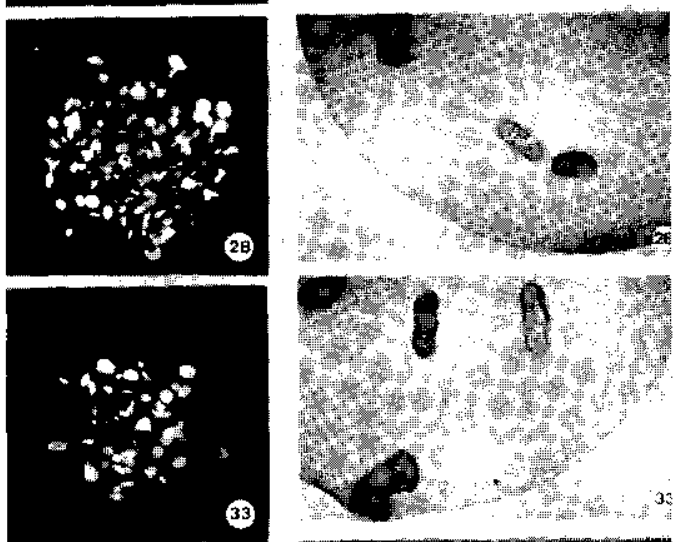

A
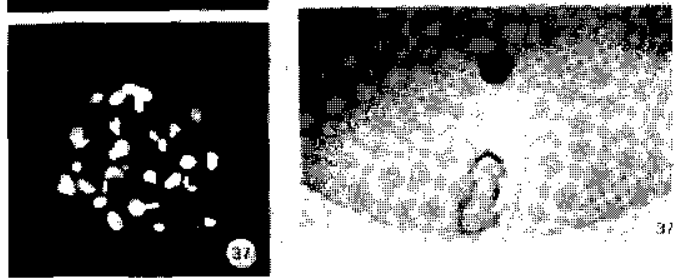
than in the beads with a high inoculum size (Fig. 4B). Colonies from both type of beads expanded but did not remain spherical. The colonies in gel beads with a low inoculum size deviated from the spherical shape already after 9 days of cultivation (Fig. $5 B$ ) while in the high inoculum-size beads deviations were observed after 22 days of cultivation (Fig. 4B). It is shown that in case of the low inoculum size, more ellipsoidshaped colonies were formed, which were not in all cases situated parallel with the gel surface. At the tips of those ellipsoid wing-like structures could be observed. In case of the high inoculum-size beads, deviations from the spherical shape were less pronounced. Colonies near the surface of the beads often looked like spheres with wings (Fig. 2). In the colony expansion model it is assumed that colonies remain spherical. Nevertheless, model predictions of macroscopic-consumption rates are quite satisfactory.

From the two experiments it can be concluded that the initial biomass concentration in gel beads influences the macroscopic substrate-consumption rate that can be reached. In case the initial biomass concentration is low, the immobilized-cell process will have less capacity than a system with a high initial biomass concentration. As a

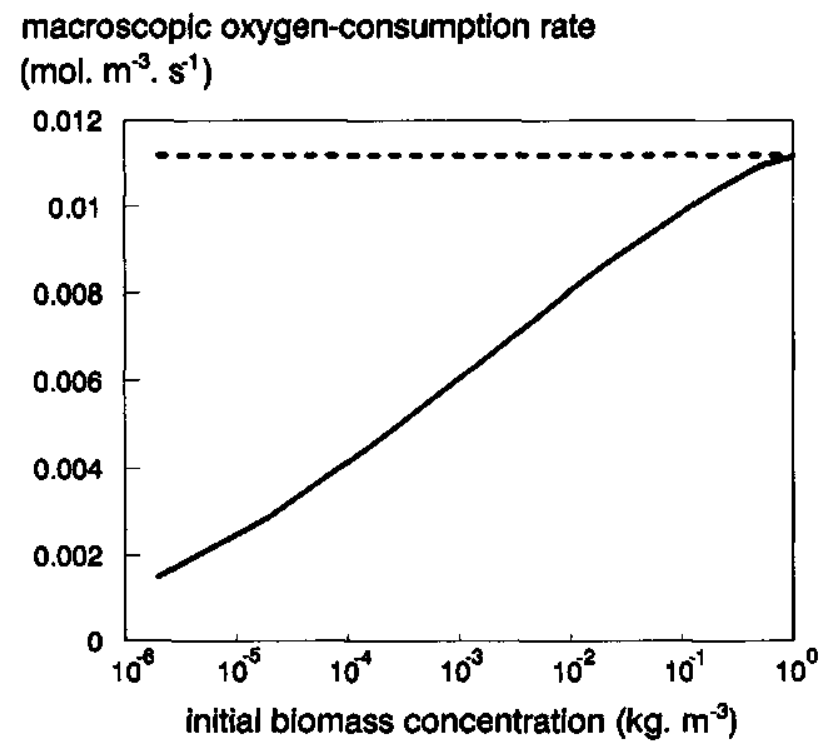

Fig. 6: Calculated macroscopic substrate-consumption rates as a function of initial biomass concentration. with the colony-expension model $(-$,$) and the pseudo-homogenous growth$ model (-). 
consequence, the colony-expansion model can be used to calculate the minimum initial biomass concentration that is needed to prevent diffusion limitation over microcolonies. In Fig. 6 the obtainable macroscopic consumption rate is given as a function of the initial biomass concentration. In order to account for the fluctuations due to of the saw-tooth curve as shown in Fig. 1, rates from day 30 to $\mathbf{4 0}$ were averaged. It is shown that under the given circumstances for Nitrosomonas europaea at initial biomass concentrations higher than about $0.5 \mathrm{~kg} . \mathrm{m}^{-3}$ the capacity of immobilized-cell reactors approaches a maximum. In comparison, the model calculations were also made with the pseudo-homogeneous growth model of De Gooijer et al..$^{2}$ which does not take diffusion limitation over micro-colonies into account. Clearly, it can be observed that capacities calculated with the colony-expansion model approach the values obtained by the pseudo-homogeneous growth model with increasing inoculum size of the gel beads at initial biomass concentrations higher than about $0.5 \mathrm{~kg} . \mathrm{m}^{-3}$.

\section{CONCLUSION}

The capacity of immobilized-cell bioreactors is not only limited by diffusion over the carrier material, but can be limited by diffusion over micro-colonies as well. In case of Nitrosomonas europaea larger colonies were formed at low inoculum sizes than at high inoculum sizes. It was shown, both by model calculations and experimentally, that diffusion limitation over micro-colonies played a role in both systems, but that in the system with larger colonies the effect was more stringent. Calculations showed that at inoculum sizes larger than $0.5 \mathrm{~kg} . \mathrm{m}^{-3}$ the effect of diffusion limitation over microcolonies can be omitted.

\section{ACKNOWLEDGEMENTS}

We like to thank the Department of Plant Cytology and Morphology for giving us the opportunity to use the equipment for microscopical analysis. 


\section{LITERATURE}

1. Barnes D., Bliss P.J. (1983) Biological control of nitrogen in wastewater treatment. E. \& F.N. Spon, London, $146 \mathrm{p}$

2. De Gooljer C.D., Wijffels R.H., Tramper J. (1991) Growth and substrate consumption of Nitrobacter agilis cells immobilized in carrageenan: part 1. dynamic modeling. Biotechnol Bioeng 38: 224-231

3. Lowry O.H., Rosebrough N.J., Farm A.L., Randall R.J. (1951) Protein measurement with the folin phend reagent. J Bid Chem 193: 265-275

4. Smith M.R., De Haan A., Wijffels R.H., Beuling E.E., Vilchez C., De Bont J.A.M. (1991) Analysis of growth and specific activities of immobilized microbial cells. Biotechnol Techn 5: 323-326

5. Stewart P.S., Robertson C.R. (1989) Microbial growth in a fixed volume: studies with entrapped Escherichia coli. Appl Microbiol Biotechnol 30: $34-40$

6. Van Neerven A.R.W., Wijfele R.H., Zehnder A.J.B. (1990) Scanning electron microscopy of immobilized bacteria in gel beads: a comparative study of fixation methods. J Microbiol Meth 11: 157-168

7. Wijfels R.H., De Gooijer C.D., Kortekaas S., Tramper J. (1991) Growth and substrate consumption of Nitrobacter agilis cells immobilized in carrageenan: part 2. model evaluation. Biotechnol Bioeng 38: 232-240

8. Wijtels R.H., De Gooijer C.D., Schepers A.W., Beuling E.E., Mallée L.F., Tramper J. (1994) Dynamic modelling of diffusion limitation over expanding micro-colonies of immobilized Nitrosomonas europaea. Submitted for publication 
INTERMEZZO 


\section{INTERMEZZO}

The growth rate of the bacteria is higher at higher oxygen concentrations. As a consequence of the oxygen concentration profile over the bead, colonies near the surface will be larger than in the centre. Not only an oxygen concentration profile will develop, but also a biomass concentration profile will develop over the gel bead. We calculated this profile and evaluated it experimentally by image analysis.

We made thin slices of the beads and observed them with a microscope. The position of each colony and the size of that colony was measured by image analysis. Image analysis can be done automatically by scanning a picture of the bead.

The radii of the colonies were translated into a biomass concentration and plotted as a function of the distance from the centre of the bead. One of the results is shown: the calculated profile is given by the line and the experimental profile by the data points. The calculated and measured profiles show that the biomass concentration is highest near the surface of the bead. 


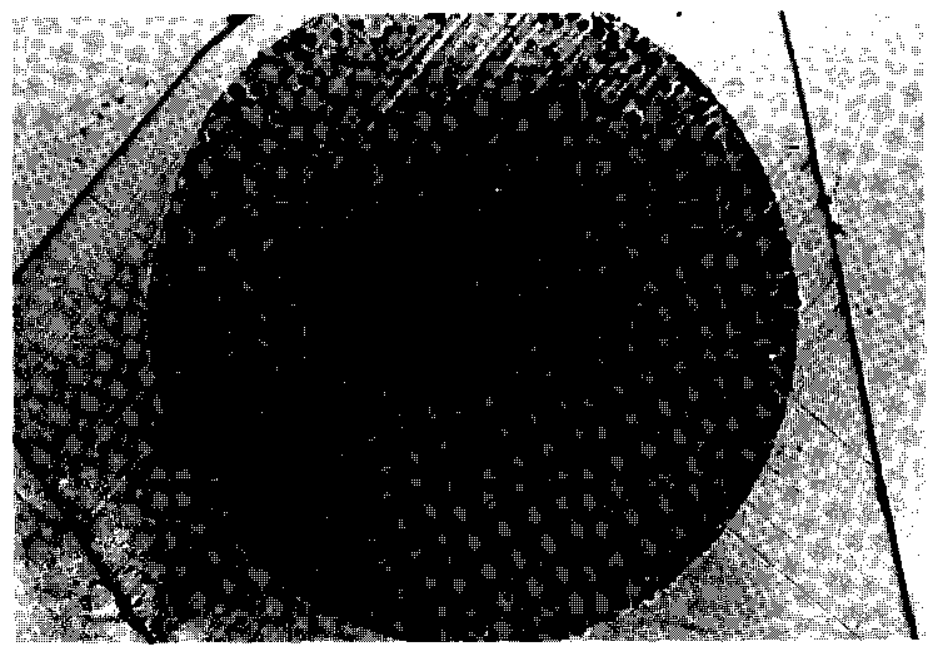

biomass concentration $\left(\mathrm{kg} \cdot \mathrm{m}^{-3}\right)$

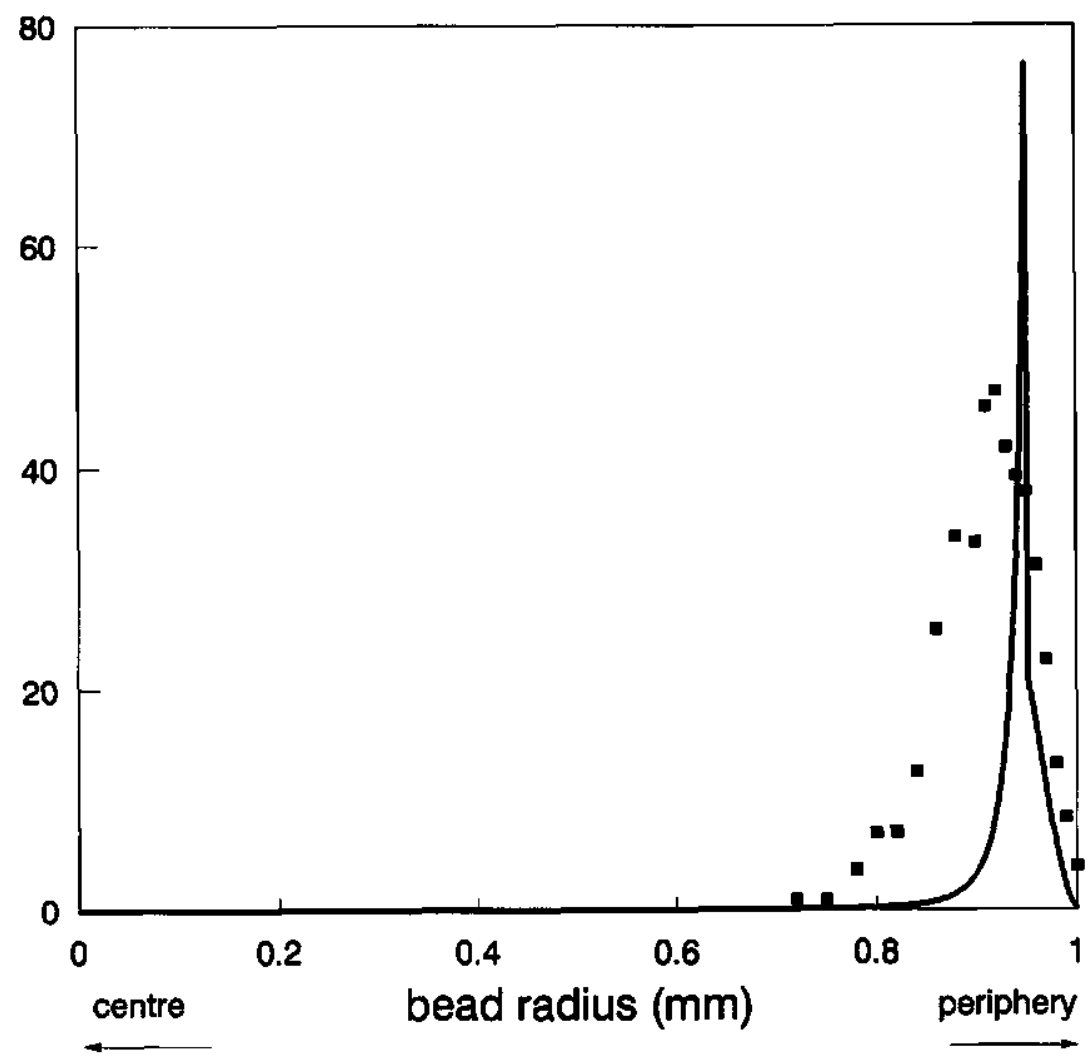




\section{CHAPTER 8}

\section{IMMOBILIZED CELLS: MODEL OR PRACTICAL SYSTEM?}

\section{MODEL SYSTEMS}

Studies with artificially immobilized nitrifying and denitrifying bacteria were started in our group more than a decade ago. ${ }^{27,29}$ At that time processes for removal of nutrients from wastewater received more and more attention as it was foreseen that in future generation wastewater-treatment plants, demands would become more and more stringent. Indeed, European laws demand a $75 \%$ reduction in nitrogen inputs to the North Sea to be achieved in 1995 compared to the 1985 inputs.

For nitrogen removal biofilm processes are considered efficient processes. The 'natural' immobilized biomass, however, is only controllable to a limited extent and the underlying mechanisms are still not very well understood. For this reason we study a better defined and a more controllable system, consisting of 'artificially' immobilized pure strains of nitrifying and denitrifying bacteria. In order to learn more about these underlying mechanisms we use pure cultures with known kinetics, entrapped in gel beads with known diffusion coefficients and geometry.

We use nitrification as our key process to understand immobilized-gel processes in general, not only because of the environmental importance, but also because it is 
a perfect model, as the organisms are autotrophic, for which reason we do not have to work under aseptic conditions and as they have very slow growth rates for which reason there is sufficient time to study transient states. For comparison, with immobilized $E$. coli cells it would take less than a day to reach a maximum capacity, while with immobilized Nitrobacter agilis cells it takes about 15 days. The research, however, has been set up in such a way that basic information obtained from this system is also applicable to any other immobilized-cell process.

Initially the research was concentrated on characterization of activity and growth of immobilized cells and to describe the growth qualitatively. This period was concluded by describing, still qualitatively, growth in colonies, that are expanding with similar rates all over the beads just after start-up and, as time proceeds, mainly near the gel surface due to diffusion limitation as is shown in Fig. $1 .{ }^{34}$ Formation of such a biofilm has also been shown for many other processes. ${ }^{3.8,14,33}$

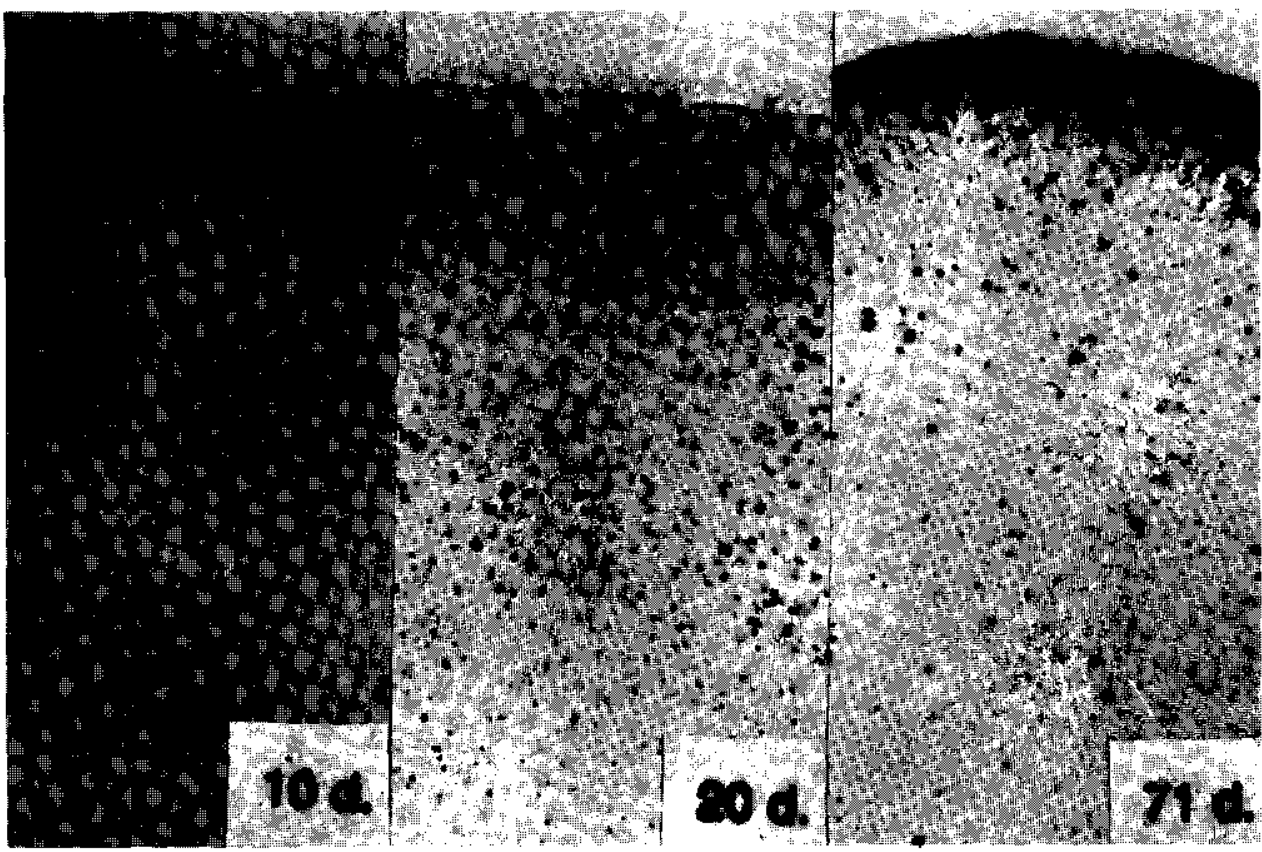

Fig. t: Pictures of coupes of carrageenan beads containing Nitrobacter agilis after 10, 20 and 71 days of continuous cultivation. 


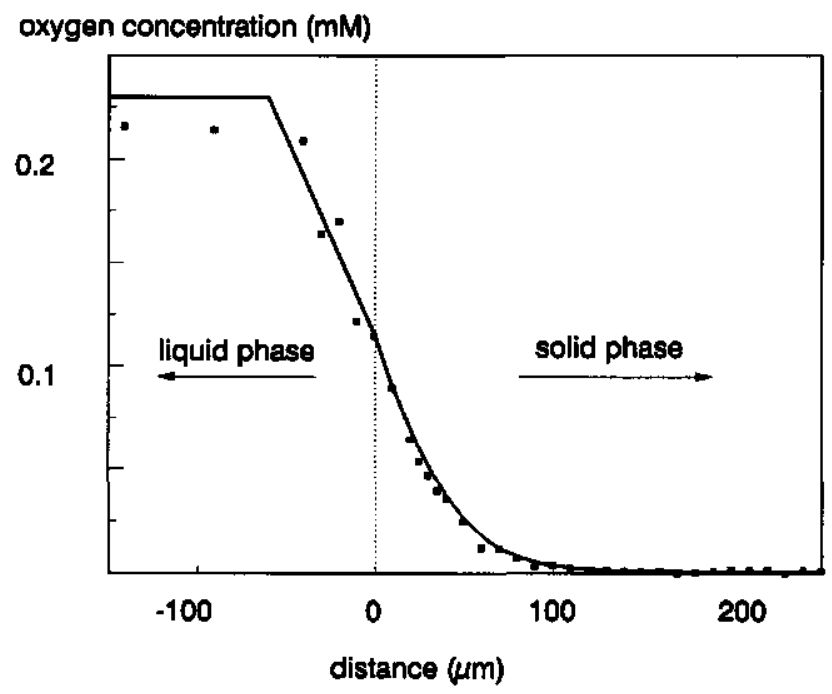

Fig. 2: Experimental (markers) and simulated (line) oxygen concentration profiles in an agar slab with immobilized Nitrobacter agills after 21 days of cultivation.

In the subsequent period we tried to quantify the observations by model descriptions. Initially the most simple situation was studied, ${ }^{5,36,37}$ i.e., growth of Nitrobacter agilis, which does not produce acid, such that the occurrence of $\mathrm{pH}$ profiles across the gel matrix was excluded. The cell-growth model was developed ${ }^{5}$ and evaluated experimentally. ${ }^{36,37}$ The conclusion was that the model described our experiments well (Fig. 2). Because the model was built up from general equations and the parameters that were used in the cell-growth model were not fitted to the experimental results but directly obtained from literature or from separate experiments, it could be used in principle for any immobilized-cell system. A similar model was developed by Monbouquette et al. for immobilized E. coli. ${ }^{15}$

To demonstrate the general applicability, evaluation was extended to immobilized Nitrosomonas europaea cells. It was in this case shown that model and experimental results did not match because of the influence of diffusion limitation over micro- 
colonies Fig. $3 A .{ }^{38}$ For this reason the growth model was extended by expressing growth as expansion of colonies, ${ }^{6,18,39}$ by implementation colony release when the colony surface and the bead surface merge and by considering diffusion limitation over these colonies. Predictions with this extended model did match with experimental results for Nitrosomonas europaea (Fig. 3B) and predicted those of Nitrobacter agilis (Fig. $3 \mathrm{C}$ ) very well. ${ }^{38}$ It was shown that there is a relation between the inoculum size of the gel beads and the ultimate capacity reached. ${ }^{39}$ With the model it can be calculated what should be the minimum inoculum size to maximize the capacity of the immobilized-cell system. The simulations are in principle valid for any immobilized-cell system. With the knowledge built up now, it is possible to optimize the process and it thus forms a basic tool for efficient reactor design.

macroscopic consumption rate $\left(\mathrm{mol} . \mathrm{m}^{3} . \mathrm{s}^{-1}\right)$

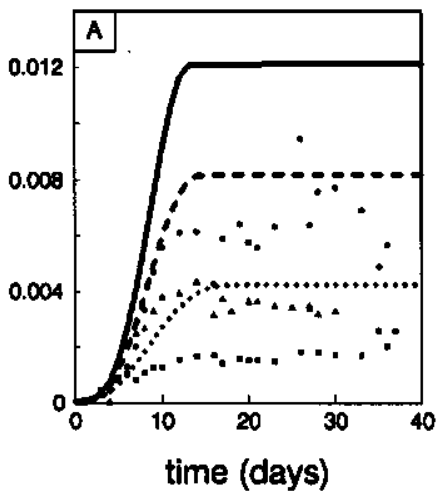

macroscopic consumption rate $\left(\mathrm{mol} . \mathrm{m}^{-3} \cdot \mathrm{s}^{-1}\right)$

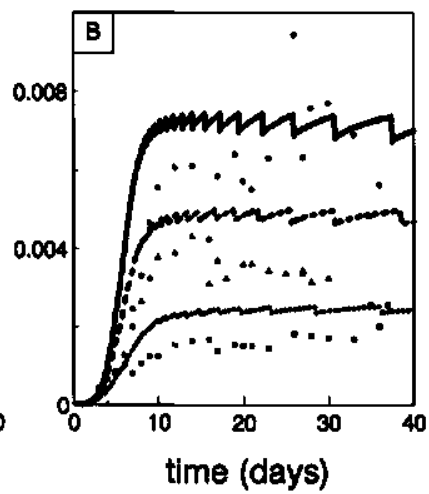

macroscopic consumption rate $\left(\mathrm{mol} . \mathrm{m}^{-3} \cdot \mathbf{s}^{-1}\right)$

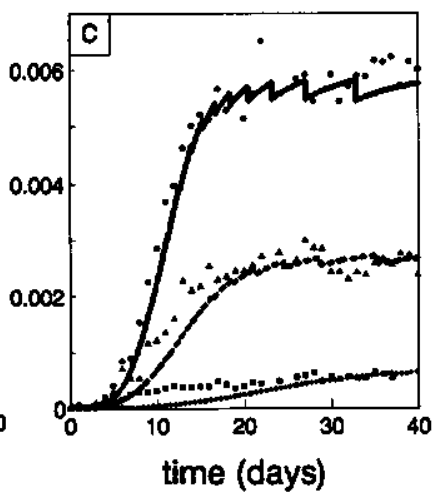

Fig. 3: Observed (markers) and predicted (lines) overall oxygen consumption rates of immobilized Nitrosomonas europaee (A and B) and Nitrobacter agllis (C) after 21 days of cultivation. For simulations of (A) diffusion limitation over the micro-colonies was not considered while for $(B)$ and (C) it was. 


\section{APPLICATION OF IMMOBILIZED CELLS}

\section{Nitrification and denitrification}

Model predictions and experiments have shown that high capacities can be reached in reactors containing artificially immobilized nitrifying bacteria. ${ }^{36}$ This has been the reason to consider the possibility of using immobilized cells not only as a model, but as a practical system as well. Therefore, more applied projects have been initiated. For example the effect of low temperatures on performance are studied in an European research project of the Wageningen Agricultural University and the Norwegian Institute of Water Research. It has been shown that by immobilization the initially kinetic-limited process becomes diffusion limited. As diffusion is less temperature dependent than bacterial-growth rate, the process is less sensitive to temperature changes, such that even under winter conditions high capacities can be reached. ${ }^{35.40}$

One of the elements that will receive much attention in our future research is the possibility of complete nitrification, denitrification and organic-carbon removal in a single-reactor system.

In conventional wastewater-treatment systems nitrification and denitrification are difficult to combine within a single reactor at high rates. Generally organic compounds are first oxidized before nitrification is executed. To integrate denitrification in such a process, an anaerobic stage can be introduced as a first or a last step. If it is introduced as a first step, part of the effluent of the nitrifying reactor has to be recycled. The result is, that part of the produced nitrate, depending on the recycle ratio, will not be converted. If it is introduced as a last step, a part of the influent has to be by-passed to the denitrification reactor in order to introduce organic compounds, needed for the denitrification. As a result some nitrogen is discharged as ammonia with the effluent. In none of these situations a complete nitrogen removal is thus achieved. One of the possibilities to integrate nitrification and denitrification in a single reactor is by co-immobilization of the bacteria involved. ${ }^{11,19,20,27,28}$ Due to diffusion limitation of oxygen the nitrifying organisms will concentrate in a biofilm just under the surface of a gel particle, leaving the anoxic central part completely unused. Denitrification may occur in the bead core if suitable denitrifying bacteria are present and if organic substrate is available. This "magic bead" concept was presented by 
Tramper ${ }^{27,29}$ and Santos et al. ${ }^{19,20}$ and is shown in Fig. 4.

Fig. 4: The magic bead concept. ${ }^{10,20}$

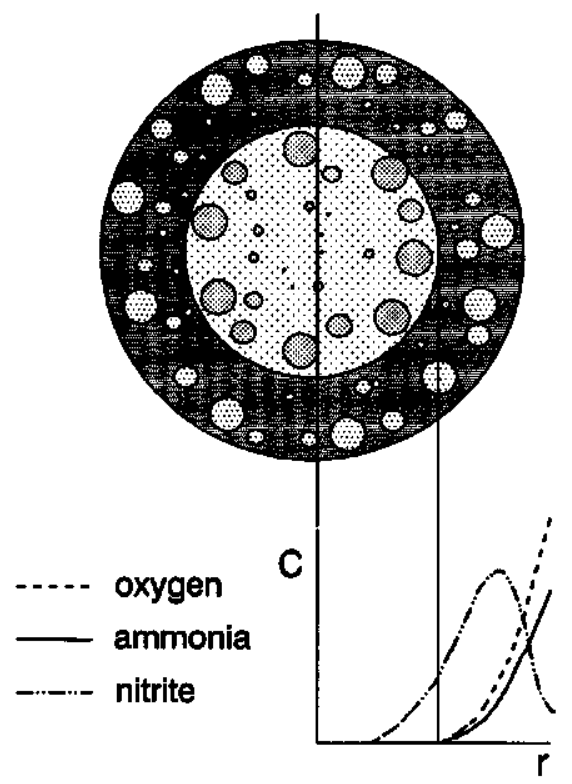

For application of artificially immobilized cells two further criteria have to be met: the production process of immobilized cells needs to be economically attractive and the produced gel particles need to be stable for a prolonged period. For this reason, studies were executed on the economical feasibility of the immobilized-cell system in addition to experiments on stability of the support material. It was shown that if gel beads remain stable for a period of more than 2 months, application of immobilized cells for nitrification is economically attractive.

Carrageenan and alginate are both polymeric materials that need to be stabilized by counter ions. If these ions are not present, the beads will dissolve, which make these polymers not suitable for all applications, such as treatment of domestic wastewater. Presently, research is being done with alternative materials, both within our group and in other research groups. Results of these studies look promising. Alternative materials that have been used for nitrification and show good perspectives in respect to stability are polyvinyl alcohol, ${ }^{1,17}$ polyethylene glycol, ${ }^{21,25}$ polyacrylamide ${ }^{21,24}$ and polycarbamoylsulfonate. ${ }^{18,31}$ The process with the polyethylene-glycol resin has already been scaled up to a scale of $750 \mathrm{~m}^{3} .^{25}$ 
Model or practical system?

\section{From immobllized enzymes to immobilized whole cells}

One of the first applications of immobilized biocatalysts is the immobilization of glucose isomerase for the production of high fructose corn syrup..$^{30}$ Especially for glucose isomerase immobilization was an ideal solution because of the high price of the enzyme. The enzyme can be reused when it is immobilized. Immobilized enzymes have been used for the production of amino acids as well. A limitation of the use of immobilized isolated enzymes is their high cost of purification, often the need of cofactors, and loss of enzyme activity during immobilization and operation. An alternative approach is the use of immobilized cells. Several processes have been applied for the production of amino acids by immobilized cells. Initially non-growing cells were used. ${ }^{4}$ Industrially these systems have been used for the continuous production of e.g. L-alanine ${ }^{22}$ and L-malic acid ${ }^{23}$. Immobilized growing cells have also been used. ${ }^{10,24,26,32}$ Other possible applications have been summarized by Tanaka and Nakajima ${ }^{24}$ : organic acids, antibiotics, steroids, enzymes, vitamin B12 and alcohols. Also three processes with immobilized yeast cells have been applied for the production of carbon dioxide in sparkling wines and for the production of alcohol containing and alcohol-free beer (text box).

Immobilized yeast cells for beverage production

Traditional fermentations in food industry are seldom replaced by alternative processes as often producers are afraid that small changes in taste influence the fame of the product negatively, even if the fermentation time is reduced drastically. One of the exceptions is the production of beer with in alginate immobilized yeast cells by the Hwa-Kuang brewery in Shanghai. ${ }^{12}$ Also for the production of alcohol-free beers and the post fermentation of sparkling wines immobilized yeasts are used. In case of the introduction of new products, like alcohol-free beer, there is no risk that the product quality is influenced by new technologies and novelties can therefore be more easily implemented. For alcohol-free beer columns with immobilized yeast cells are used. ${ }^{9,13}$ For the production of sparkling wines, traditionally secondary fermentation is done in the bottle by adding some sugar and yeast cells. The only function of this fermentation is production of carbon-dioxide gas to make the wine sparkling. The yeast cells need to be removed after fermentation to obtain a clear product. For this reason yeast cells need to sediment in the neck of the bottle, which is a slow process for which much space and labour is needed. By immobilization of the cells, sedimentation is much faster. ${ }^{7}$ 
The use of immobilized cells shows also possibilities for recombinant microbial cells (text box).

\section{Recombinant microbial cells}

Immobilization can be beneficial in the case of genetically improved microbial cells. At each cell division mutations occur in growing recombinant celis to much simpler forms. Mutant cells generally grow faster and the originally recombinant form would be overgrown in continuous culture if there is no antibiotic selection pressure applied.

In case cells are immobilized, the faster growing colonies at the periphery will erupt after a limited number of cell divisions. The remaining colonies contain a higher percentage of the recombinant form and will grow until they reach the surface and erupt. As a result the eruption provides wash out that affects the non-recombinant plasmid-containing cells to a much higher degree than the plasmid-containing cells. Therefore, immobilized cells form a more stable system than continuous-cultivated, suspended, genetically improved, microbial cells. ${ }^{2}$

\section{PERSPECTIVES OF IMMOBILIZED CELLS IN ENVIRONMENTAL BIOTECHNOLOGY}

As indicated, immobilized cells and the models developed for describing their behaviour, can be used for much more processes than the nitrification process as presented here. In principle it can be used for degradation of any compound or accumulation of certain compounds as long as there is a suitable microorganism available.

Especially in case of difficult-degradable compounds by specific slow-growing organisms, immobilization can lead to an efficient system. A combination of a collection of microorganisms which specifically degrade certain compounds, knowledge about their kinetics and the diffusional properties of the compounds and introduction into the model as presented, would result in specific solutions for the treatment of the pollutant-containing medium. Based on the amount of pollutants to be removed and the types of pollutants, process conditions can be designed for optimal degradation (Fig. 5).

Other systems that are potentially of interest are reactions in which accumulation 
occurs, e.g. phosphate or heavy metals. The biomass concentration in the carriers is generally high. In case of accumulation of a compound in the immobilized bacteria, high concentrations of this compound are reached in the particles which are easy to separate from the pollutant containing medium. Such a system may be suitable for recovery of the waste as a raw material.

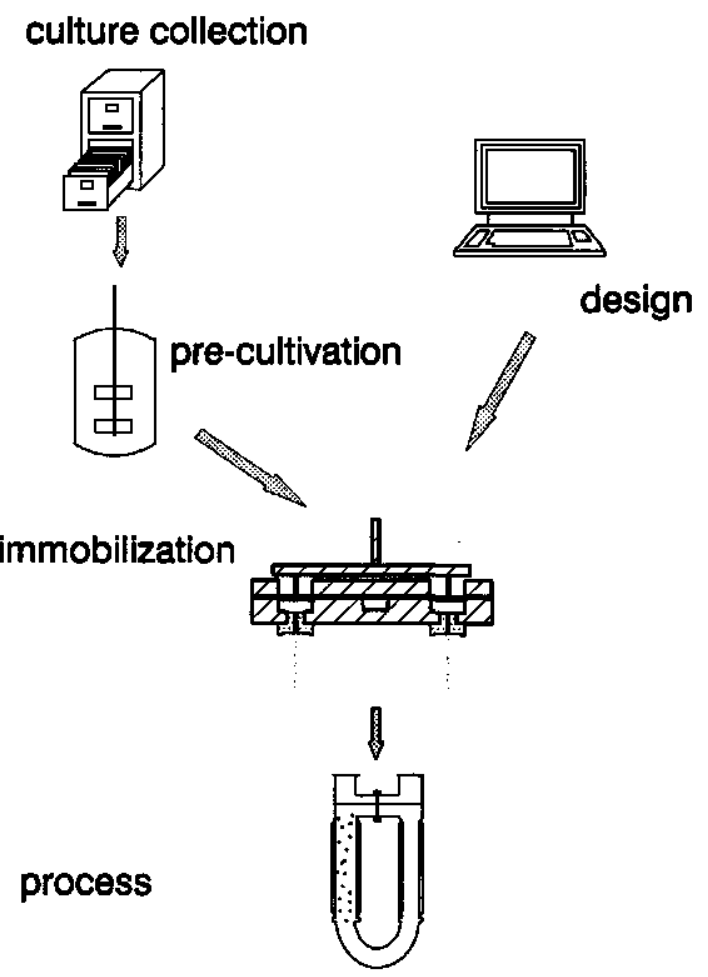

Fig. 5: Schematic representation of general approach for the development of a process with immobilized cells.

\section{LITERATURE}

1. Ariga O., Takagi H., Nishizawa H., Sano Y. (1987) Immobilization of microorganisms with PVA hardened by iterative freezing and thawing. J Ferment Technol 65 (6): 651-658 
2. Barbotin J.N., Sayadi S., Nasri M., Thomas D. (1990) Improvement of plasmid stability by immobilization of recombinant microorganisms. Ann NY Acad Scl 58: 41-53

3. Chibata l., Tosa T., Fujimara F. (1983) Immobilized living microbial cells. In: Annual reports on fermentation processes, vol. 6. Ed.: Tsao G.T., Academic Press, London, p 1-22

4. Constantinides A., Bhatia D., Vieth W.R. (1981) Immobilization of Brevibacterium flavum cells on collagen for the production of glutaminic acid in a recycle reactor. Biotechnol Bioeng 23: 899916

5. De Gooljer C.D., Wijttels R.H., Tramper J. (1991) Growth and substrate consumption of Nitrobacter agilis cells immobilized in carrageenan. Part 1: Dynamic modeling. Biotechnol Bioeng 38: 224-231

6. De Gooljer C.D., Wijffels R.H., Tramper J. (1992) Dynamic modeling the growth of Immobilized nitrifying bacteria: biofilm development. In: Biofilms-Science and Technology. Eds. L.F. Melo, T.R. Bott, M. Fletcher, B. Capdeville. Kluwer Academic Publishers, the Netherlands, p 291-296

7. Godia F., Casas C., Sola C. (1991) Application of immobilized yeast cells to sparkling wine fermentation. Biotechnol Progr 7: 468-470

8. Gosmann B., Rehm H.J. (1986) Oxygen uptake of microorganisms entrapped in Ca-alginate. Appl Microbiol Biotechnol 23: 163-167

9. Fieman F. (1992) Lageringstijd pils sterk verkort met geïmmobiliseerde gisten. Food Management 10 (3): 25-27

10. Fujimura M., Kato J., Tosa T., Chibata I. (1984) Continuous production of L-arginine using immobilized growing Serratia marcescens cells: effectiveness of supply of oxygen gas. Appl Microbiol Biotechnol 19: 79-84

11. Kokufuta E., Shimohashi M., Nakamura I. (1988) Simultaneously occurring nitrification and denitrification under oxygen gradient by polyelectrolyte complex-coimmobilized Nitrosomonas europaea and Paracoccus denitriflcans cells. Blotechn Bioeng 31: 382-384

12. Linko P., Linko Y.Y. (1984) Industrial applications of immobilized cells. CRC Critical Reviews in Biotechnology 1 (4): 289-337

13. Lommi H.O. (1990) Immobilized yeast for maturation and alcohol-free beer. Brewing \& Distilling International 21 (5): $22-23$

14. Mahmoud W., Rehm H.J. (1986) Morphological examination of immobilized Streptomyces aurofaciens during chlortetracycline fermentation. Appl Microbiol Blotechnol 23: 305-3108

15. Monbouquette H.G., Sayles G.D., Ollis D.F. (1990) Immobilized cell biocatalyst activation and pseudo-steady-state behavior: model and experiment. Biotechnol Bioeng 35: 609-629

16. Muscat A., Beyersdort J., Vorlop K.D. (1993) Poly(carbamoylsulfonate), a material for immoblization: synthesis, diffusion and mechanical properties. Biotechnol Techn 7 (8): $591-596$

17. Myoga H., Asano H., Nomura Y., Yoshida H. (1991) Effects of immobilization conditions on the nitrification treatability of entrapped cell reactors using PVA freezing method. Wat Sci Tech 23: 1117-1124

18. Saimon P.M. (1989) Mass transport phenomena in reactors containing entrapped enzymes or 
bacterial cells. PhD thesis Stanford University, USA

19. Santos V.A., Tramper J., Wujtels R.H., Tramper J. (1992) Integrated nitrification and denitrification with immoblized microorganisms. In: Biofilms-Science and Technology. Eds. L.F. Melo et al. Kluwer Academic Publishers, the Netherlands, p 449-453

20. Santos V.A., Tramper J., Wijftels R.H. (1993) Simultaneous nitrification and denitrffication using immobilized microorganisms. Blomat Art Cells \& Immob Biotech 21 (3): 317-322

21. Tada M., KImata T., Mori N., Emori H. (1990) Nitrogen removal systems using immobilized microorganisms in synthetic resin. Hitachi Review 39 (6): 379-386

22. Takamatsu S., Yamamoto K., Tosa T., Chibata I. (1981) Stabilization of L-aspartate Bdecarboxylase activity of Pseudomonas decunhae immobilized with carrageenan. I Ferment Technol 59(6): 489-493

23. Takata I., Yamamoto K., Tosa T., Chibata I. (1980) Immobilization of Brevibacterium flavum with carrageenan and its application for continuous production of L-malic acid. Enzyme Microbid Technol 2: 30-36

24. Tanaka A., Nakajima H. (1990) Application of immobilized growing cells. In: Advances in Biochemical Engineering/Biotechnology, vol. 42. Ed.: Fiechter A. Springer-Verlag, Berlin Heidelberg, p 97-131

25. Tanaka K., Tada M., Kimata T., Harada S., Fujil Y., Mizuguchi T., Mori N., Emori H. (1991) Development of new nitrogen removal systern using nitrifying bacteria immobilized in synthetic resin pellets. Wat Sci Tech 23: $681-690$

26. Tanaka T., Yamamoto K., Towprayoon S., Nakajima H., Sonomoto K., Yokozeki K., Kubota K., Tanaka A. (1989) Continuous production of L-serine by immobilized growing Corynebacterium glycinophilum cells. Appl Microbiol Biotechnol 30: 564-568

27. Tramper J. (1984). Nitrification and denitrification by immobilized bacteria. Third European Congress on Biotechnology, München, 10-14 September 1984, p 363-368, VCH Weinheim

28. Tramper J. (1987) Nitrification and denitrification by immobilized viable cells. In: Enzyme Engineering 8, ed. A.I. Laskin, L. Mosbach, D. Thomas, L.B. Wingard Annuals of the New York Academy of Sciences 501: 362-366

29. Van Ginkel C.G., Tramper J., Luyben K.Ch.A.M., Klapwijk A. (1983) Enzyme Microb Technol 5: $297-303$

30. Venkatasubramanlan K., Harrow L.S. (1979) Design and operation of a commercial immobilized glucose isomerase reactor system. Annals of the New York Academy of Sciences 326: 141-154

31. Vorlop K.D., Muscat A., Beyersdorf J. (1992) Entrapment of microbial cells within polyurethane hydrogel beads with the advantage of low toxicity. Biotechnol Techn 62 (6): 483-488

32. Wada M., Uchida T., Kato J., Chibata 1. (1980) Continuous production of L-isoleucine using immobilized growing Serratia marcescens cells. Biotechnol Biceng 22: 1175-1188

33. Wada M., Kato J., Chibata I. (1980) Continuous production of ethanol using immobilized growing yeast cells. Appl Microbiol Biotechnol 10: 275-287

34. Wijffels R.H., Tramper J. (1989) Performance of growing Nitrosomonas europaea cells 
immobilized in א-carrageenan. Appl Microbiol Biotechnol 32: 108-112

35. Wijffels R.H., Hunik J.H., de Gooijer C.D., Tramper J. (1990) Nitrification with immobilized bacteria in air-lift loop reactors: modelling and application. Proceedings 5th European Congress on Biotechnology, Copenhagen July 8-13, 1990, vol. 1, C. Christiansen, L. Munck, J. Villadsen, Munksgaard International Publisher, Copenhagen, p 392-395

36. Wijtfels R.H., De Gooijer C.D., Kortekass S., Tramper J. (1991) Growth and substrate consumption of Nitrobacter agilis cells immobilized in carrageenan. Part 2: Model evaluation. Biotechnol. Bioeng. 38: 232-240

37. Wijffels R.H., Eekhof M.R., De Beer D., Van Den Heuvel J.C., Tramper J. (1994) Pseudosteady-state oxygen concentration profiles in an agar slab containing growing Nitrobacter agilis. Submitted

38. Wijffels R.H., De Gooljer C.D., Schepers A.W., Beuling E.E., Malióe L.R., Tramper J. (1994) Growth of immobilized Nitrosomonas europaea: implementation of diffusion limitation over microcolonies. Submitted

39. Wijffels R.H., Schepers A.W., Smit M., De Goojjer C.D., Tramper J. (1994) Effect of initial biomass concentration on the growth of immobilized Nitrosomonas europaea. Submitted

40. Wijtfels R.H., Englund G., Munik J.H., Leenen E.J.T.M., Bakketun A., Günther A., Obón de Castro J.M., Tramper J. (1994) Effects of diffusion limitation on immobilized nitrifying microorganisms at low temperatures. Submitted 


\section{SUMMARY}

Nitrosomonas europaea and Nitrobacter agilis are nitrifying bacteria. Subsequently they oxidize ammonia to nitrite and nitrite to nitrate. Nitrification is a key process for the removal of nitrogen compounds from wastewater.

Ammonia is removed from wastewater by supply of oxygen to a reactor containing nitrifying bacteria. The hydraulic retention time in a reactor with suspended nitrifying bacteria needs to be sufficient to prevent wash-out of the bacteria. By immobilization, i.e., attach or entrap the organisms in a support material and retain the support material in the reactor, it is possible to run a reactor under wash-out conditions and consequently execute the nitrification process in compact systems. In practice, biofilm reactors are most commonly used for this.

In this research, artificial immobilized nitrifying bacteria are studied. The bacteria were suspended in a gel (carrageenan) and solid spheres were produced from this gel. The artificial immobilized cells were used as a model system for biofilm processes. By using the model system we were able to perform fundamental studies of growth within the support and substrate conversion by the immobilized cells.

Growth of immobilized cells has been described qualitatively in chapter 2 . Immobilized cells form small colonies as the result of growth. Initially, such expanding micro-colonies were observed over the entire gel bead, but after some time growth just under the surface of the spheres was faster because of diffusion limitation over the support.

The qualitative observations have been quantified by modelling the significant transport processes (radial diffusion through the support and external mass transfer across the stagnant liquid layer surrounding the spheres), substrate consumption and growth (chapter 3 ). The model that we developed calculates substrate consumption and growth over time and shows for example that initially growth will take place all over the bead and after some time especially just under the surface of the beads. This is in agreement with our previous qualitative observations. The model has been validated experimentally by immobilized Nitrobacter agilis cells by determination of macroscopic substrate consumption rates, substrate profiles and biomass profiles (chapter 4 and 
5). Experimental results were in close agreement with the model results.

The model consisted of general equations and the parameters were obtained from separate experiments or literature. For this reason the model should be general applicable. To demonstrate the general applicability the model was also used for Nitrosomonas europaea (chapter 6). The calculated macroscopic consumption rates, however, were much larger and the biomass concentration much lower than we found experimentally. We could show that in this experiment not only diffusion limitation over gel beads but also diffusion limitation over the micro-colonies was important. The size of micro-colonies of Nitrosomonas europaea was much larger than of Nitrobacter agilis in the previous experiment. This has been the reason to implement growth of biomass by expansion of colonies and taking diffusion limitation over those colonies into account in our model. Validation of this colony-expansion model showed that experimental and simulated results agreed much better. Application of the colonyexpansion model to our previous experiment with Nitrobacter agilis also gave good results.

The size of the micro-colonies formed is dependent to a higher degree on the amount of organisms that is immobilized than on the type of organism. At low initial biomass concentrations, a few but large colonies will be formed. At high initial biomass concentrations much more and much smaller colonies will be formed. Those smaller colonies experience less diffusion limitation and consequently the substrate-utilization capacity of such beads will be higher. This effect could be demonstrated, both experimentally and by simulations with immobilized Nitrosomonas europaea (chapter 7).

The models that are presented in this thesis give insight in growth and substrateconversion capacity of immobilized cells. Our approach was general and as a consequence the insight that is obtained is not only important for nitrification, but can be used for other immobilized-cell processes as well. 


\section{SAMENVATTING}

Nitrosomonas europaea en Nitrobacter agilis zijn nitrificerende bacteriën. Achtereenvolgens oxyderen zij ammonium tot nitriet en nitriet tot nitraat. Nitrificatie vormt een belangrijke stap in de verwijdering van stikstofverbindingen uit afvalwater.

In een reactor wordt afvalwater met daarin ammoniak met behulp van zuurstof door nitrificerende bacteriën verwijderd. Bij gebruik van gesuspendeerde nitrificerende bacteriën moet de verblijttijd van het afvalwater in de reactor groot genoeg zijn om de bacteriën niet uit te spoelen. Door de bacteriën te immobiliseren, dat wil zeggen ze vast te leggen op of in een dragermateriaal en dat dragermateriaal achter te houden in de reactor, is het mogelijk onder uitspoelcondities te werken en dientengevolge nitrificatieprocessen in compacte systemen uit te voeren. In de praktijk wordt dit meestal toegepast in biofilmreactoren.

In dit onderzoek zijn kunstmatig geïmmobiliseerde nitrificerende bacteriën bestudeerd. Bacteriën werden gesuspendeerd in een gel (carrageen) en van dit gel werden bolletjes gemaakt. Dit systeem vormde een modelsysteem voor biofilmprocessen. Aan de hand van dit modelsysteem is fundamenteel onderzoek gedaan naar groei en substraatomzetting van geïmmobiliseerde cellen.

In hoofdstuk 2 is de groei van geïmmobiliseerde cellen kwalitatief beschreven. Geïmmobiliseerde cellen blijken als gevolg van groei kleine kolonies in het gel te vormen. In eerste instantie worden dergelijke expanderende kolonies over de gehele bol waargenomen, maar in later stadium is groei aan het oppervlak sneller dan in het centrum van de bollen als gevolg van diffusielimitatie over het gelbolletje.

In hoofdstuk 3 zijn deze kwalitatieve waarnemingen gekwantificeerd door de belangrijkste stoftransportprocessen (diffusie over het gel in radiële richting en stoftransport over de stagnante vloeistoflaag om de bollen), substraatconsumptie en groei te modelleren. Het ontwikkeide model beschrijt substraatconsumptie en groei in de tijd en laat bijvoorbeeld zien, dat groei in eerste instantie over de gehele bol plaats vindt en later met name juist onder het oppervlak en komt dus overeen met onze kwalitatieve waarnemingen. Dit model is gevalideerd met behulp van geïmmobiliseerde Nitrobacter agilis cellen door gemeten macroscopische 
substraatconsumptie, substraatprofielen en biomassaprofielen te vergelijken met de modelvoorspellingen (hoofdstuk 4 en 5). Het ontwikkelde model bleek onze experimenten goed te beschrijven.

Het ontwikkelde model was opgebouwd uit algemene vergelijkingen en de modelparameters waren verkregen uit andere experimenten en uit de literatuur. Het model is daarom in principe algemeen geldig. Om die algemene geldigheid aan te tonen werd het model ook getoetst met Nitrosomonas europaea (hoofdstuk 6). De voorspelde macroscopische consumptiesnelheid bleek echter veel hoger, en de biomassaconcentratie veel lager te zijn dan de experimenteel verkregen waarden. Aangetoond kon worden dat tijdens dit experiment niet alleen diffusielimitatie over de gelbollen maar ook diffusielimitatie over de gevormde microkolonies van belang was. De microkolonies van Nitrosomonas europaea bleken veel groter te zijn dan die van Nitrobacter agilis in het vorige experiment. Naar aanleiding van deze waarneming is de groei in het model opgenomen door discrete kolonies te laten expanderen en diffusielimitatie over die kolonies mee te nemen. Na toetsing bleek dit model veel beter de experimenten te beschrijven. Daarnaast bleek dit model ook het experiment dat we uitgevoerd hadden met Nitrobacter agilis goed te beschrijven.

De grootte van de gevormde microkolonies is niet zozeer afhankelijk van het type organisme dat geïmmobiliseerd wordt, maar veel meer van de hoeveelheid organismen die geïmmobiliseerd worden. Indien de initiële biomassaconcentratie laag is worden weinig, maar relatief grote kolonies gevormd. $\mathrm{Bij}$ een hoge initiële biomassaconcentratie worden veel meer, maar veel kleinere kolonies gevormd. Over die kleinere kolonies is er minder diffusielimitatie waardoor de omzettingscapaciteit van dergelijke bollen ook veel groter is. Dit werd zowel door onze modelvoorspellingen als in experimenten met Nitrosomonas europaea aangetoond (hoofdstuk 7).

De in dit proefschrift beschreven modellen geven inzicht in de groei en omzettingscapaciteit van geïmmobiliseerde cellen. De benadering van geïmmobiliseerde cellen was zo algemeen, dat verkregen kennis niet alleen voor nitrificatie van belang is, maar in principe voor alle geïmmobiliseerde bacteriën. 


\section{BIBLIOGRAPHY}

Sayed S., Van Der Zanden J., Wijffels R., Lettinga G. (1988) Anaerobic digestion of the various fractions of slaughterhouse wastewater. Biol Wastes 23: 117-142 Wijffels R.H., Tramper J. (1989) Performance of growing Nitrosomonas europaea cells immobilized in $\kappa$-carrageenan. Appl Microbiol Biotechnol 32: 108-112

Van Neerven A.R.W., Wijffels R.H., Zehnder A.J.B. (1990) Scanning electron microscopy of immobilized bacteria in gel beads: a comparative study of fixation methods. J Microb Meth 11: 157-168

De Gooljer C.D., Wuffels R.H., Tramper J. (1990) Modelling the growth of immobilized Nitrobacter agilis cells. Physiology of Immobilized Cells, Proceedings of an International Symposium held at Wageningen, The Netherlands, 10-13 December 1989, J.A.M. de Bont, J. Visser, B. Mattiasson, J. Tramper, Elsevier Science Publishers B.V., Amsterdam p 355-360

Wijftels R.H., De Gooljer C.D., Kortekaas S, Tramper J. (1990) Nitrobacter agilis immobilized in carrageenan: oxygen consumption and biomass density. Physiology of Immobilized Cells, Proceedings of an International Symposium held at Wageningen, The Netherlands, 10-13 December 1989, J.A.M. de Bont, J. Visser, B. Mattiasson, J. Tramper, Elsevier Science Publishers B.V., Amsterdam p 475-480

Wijffels R.H., Schukking G.C., Tramper J. (1990) Characterization of a denitrifying bacterium immobilized in $\kappa$-carrageenan. Appl Microbiol Biotechnol 34: 399-403

Wijtfels R.H., Hunik J.H., De Gooijer C.D., Tramper J. (1990) Nitrification with immobilized bacteria in airlift loop reactors: modelling and application. Proceedings 5 th European Congress on Biotechnology, Copenhagen July 8-13, 1990, vol. 1, C. Christiansen, L. Munck, J. Villadsen, Munksgaard International Publisher, Copenhagen, p 392-395

Wijffels R.H., Eekhof M.R., Tramper J., De Beer D., Van Den Heuvel J.C. (1991) Growth and substrate consumption by immobilized Nitrobacter agilis: validation of a dynamic model. Int. Symp. Environmental Biotechnology, 22-25 April 1991, Ostend, Belgium, pp 687-699

De Gooijer C.D., Wijffels R.H., Tramper J. (1991) Growth and substrate consumption 
of Nitrobacter agilis cells immobilized in carrageenan. Part 1: Dynamic modeling. Biotechnol Bioeng 38: 224-231

Wijffels R.H., De Gooljer C.D., Kortekaas S., Tramper J. (1991) Growth and substrate consumption of Nitrobacter agilis cells immobilized in carrageenan. Part 2: Model evaluation. Biotechnol Bioeng 38: 232-240

Smith M.R., De Haan A., Wijffels R.H., Beuling E.E., Vilchez C., De Bont J.A.M. (1991) Analysis of growth and specific activities of immobilized microbial cells. Biotechnol Techn 5: 323-326

Wijffels R.H., Hunik J.H., De Gooijer C.D., Tramper J. (1992) Nitrification with immobilized bacteria in airlift loop reactors. Congress Agriculture \& Environment in Eastern Europe and the Netherlands, 5 \& 6 sept. 1990. Wageningen Agricultural University, $p$ 169-175

De Gooijer C.D., Wijffels R.H., Tramper J. (1992) Dynamic modeling the growth of immobilized nitrifying bacteria: biofilm development. In: Biofilms-Science and Technology. Eds. L.F. Melo, T.R. Bott, M. Fletcher, B. Capdeville. Kluwer Academic Publishers, the Netherlands, $\mathrm{p}$ 291-296

Santos V.A., Tramper J., Wijffels R.H. (1992) Integrated nitrification and denitrification with immobilized microorganisms. In: Biofilms-Science and Technology. Eds. L.F. Melo, T.R. Bott, M. Fletcher, B. Capdeville. Kluwer Academic Publishers, the Netherlands, p 449-453

Wiffels R.H., Leenen E.J.T.M., Tramper J. (1993) Possibilities of nitrification with immobilized cells in waste-water treatment: model or practical system? Wat Sci Tech 26: $233-240$

Santos V.A., Tramper J., Wijffels R.H. (1993) Simultaneous nitrification and denitrification using immobilized microorganisms. Biomat Art Cells \& Immob Biotech 21 (3): 317-322

De Gooljer C.D., Schepers A.W., Wijffels R.H., Tramper J. (1994) Dynamic modelling of the growth of immobilized Nitrosomonas europaea cells. Proceedings 6 th European Congress on Biotechnology, Firenze

Hunik J.H., Tramper J., Wijffels R.H. (1994) A strategy to scale-up nitrification processes with immobilized nitrifying cells. Biotechnol Progr, Accepted

Wijffels R.H., De Gooljer C.D., Schepers A.W., Beuling E.E., Mallée L.R., Tramper J. (1994) Growth of immobilized Nitrosomonas europaea: implementation of diffusion limitation over microcolonies. Submitted

Wijfels R.H., Schepers A.W., Smit M., De Gooijer C.D., Tramper J. (1994) Effect of initial biomass concentration on the growth of immobilized Nitrosomonas europaea. 
Submitted

Wijffels R.H., Englund G., Hunik J.H., Leenen E.J.T.M., Bakketun Å., Günther A., Obbn de Castro J.M., Tamper J. (1994) Effects of diffusion limitation on immobilized nitrifying microorganisms. Submitted

Wijffels R.H., Eekhof M.R., De Beer D., Van Den Heuvel J.C., Tramper J. (1994) Pseudo-steady-state oxygen concentration profiles in an agar slab containing growing Nitrobacter agilis. Submitted

Wijffels R.H., Tramper J. (1994) Nitrification by immobilized cells. Submitted

Wijffels R.H., Tramper J. (1994) Immobilized cells: model or practical system?

Submitted 


\section{Curriculum vitae}

René Wijfels werd op 8 februari 1960 geboren in IJzendijke. In 1977 behaalde hij het diploma HAVO aan de scholengemeenschap St. Eloy in Oostburg. Hij vervolgde zijn opleiding aan de Hogere School voor Levensmiddelentechnologie in 'sHertogenbosch en sloot deze af in 1982.

Vanaf 1982 studeerde hij aan de Landbouwuniversiteit Wageningen. In 1987 studeerde hij af in de studierichting Milieu-hygiëne met als afstudeervakken Proceskunde en Waterzuivering. Hij heeft o.a. stages gedaan bij de Technologische Dienst van de Zeeuwse Waterschappen te Terneuzen en Corporación Autonoma Regional del Cauca te Cali, Colombia.

Vanaf 1 october 1987 is hij werkzaam geweest bij de sectie Proceskunde van de Landbouwuniversiteit te Wageningen, eerst als assistent in opleiding en vanaf 1 januari 1991 als universitair docent. 